DÉBORA CRISTINA BERALDES COSTA

GESTÃO PÓS-OCUPAÇÃO EM EDIFÍCIOS REABILITADOS PARA HABITAÇÃO DE INTERESSE SOCIAL NO CENTRO DE SÃO PAULO.

Dissertação apresentada à Escola Politécnica da Universidade de São Paulo para obtenção do título de Mestre em Engenharia. 
DÉBORA CRISTINA BERALDES COSTA

\title{
GESTÃO PÓS-OCUPAÇÃO EM EDIFÍCIOS REABILITADOS PARA HABITAÇÃO DE INTERESSE SOCIAL NO CENTRO DE SÃO PAULO.
}

\author{
Dissertação apresentada à Escola \\ Politécnica da Universidade de São \\ Paulo para obtenção do título de \\ Mestre em Engenharia.
}

Área de concentração:

Engenharia Civil - Construção Civil e Urbana.

Orientador:

Prof. Dr. Witold Zmitrowicz 


\section{FICHA CATALOGRÁFICA}

Costa, Débora Cristina Beraldes.

Gestão pós-ocupação em edifícios reabilitados para habitação de interesse social no centro de São Paulo / D.C.B. Costa. -São Paulo, 2009. 164p.

Dissertação (Mestrado) - Escola Politécnica da Universidade de São Paulo. Departamento de Engenharia de Construção Civil.

1. Edifícios (Reabilitação) 2. Habitação popular I.Universi dade de São Paulo. Escola Politécnica. Departamento de Engenharia de Construção Civil II.t. 
À minha querida família, em especial meus pais Antonio Carlos e Marilise, e minha irmã Úrsula, que me apoiaram em todos os momentos desta grande jornada.

Àqueles que lutam por uma cidade mais justa. 


\section{AGRADECIMENTOS}

A Deus, por me permitir chegar ao objetivo traçado possibilitando momentos inesquecíveis de luta e crescimento;

À minha querida mãe, Marilise Beraldes Costa, por me acompanhar e defender em todos os momentos, tanto como mãe quanto como profissional, e por sempre me indicar o melhor caminho;

Ao meu querido pai, Antonio Carlos Costa, pelo exemplo de determinação e pensamento positivo que me fazem crescer e superar qualquer obstáculo;

À minha querida irmã, Úrsula Costa, pelo incomparável esforço e dedicação nas leituras e críticas ao texto;

Ao companheiro de todas as horas, Fernando Galvão, pela paciência, amor e certeza do sucesso do trabalho;

Ao Prof. Dr. Witold Zmitrowicz, pela orientação e acompanhamento durante estes anos;

À Profa. Dra. Mércia Barros, pela especial ajuda frente às dificuldades ocorridas e importantes críticas no exame de qualificação;

À Profa. Dra. Maria Ruth Amaral de Sampaio, pelas observações no exame de qualificação;

À arquiteta Valéria Bomfim, pela imensa colaboração desde a escolha do tema até os valiosos comentários e críticas sobre o texto;

Aos colegas de pesquisa do Projeto Reabilita, que me incentivaram e ajudaram a iniciar este trabalho;

Aos advogados e amigos Marisa Beraldes e Valter Baceto, pela grande ajuda nos momentos de dificuldade;

Aos moradores dos edifícios reabilitados, em especial às Sras. lara, Neuma, Neide, Josilene, e Fátima que me receberam carinhosamente;

Aos técnicos da Caixa Econômica Federal, em especial Célia, Simone e Sandra, por me receberem sempre que necessário;

Aos técnicos da Prefeitura da Cidade de São Paulo, em especial Renata e Cristina, de Cohab, e Vitório, de Habi.

Aos engenheiros Gustavo Bisacchi e Marcelo Chaves, e à arquiteta Valéria Guimarães, pela compreensão e apoio essenciais para a finalização do trabalho;

Aos funcionários do Departamento de Construção Civil, em especial Fátima Domingues, por sua colaboração e ajuda em todos os momentos necessários.

A todos os amigos e familiares que acreditaram no trabalho, meu muito obrigado! 


\section{RESUMO}

Este trabalho verifica os aspectos positivos e negativos existentes na gestão pósocupação de cinco edifícios reabilitados para Habitação de Interesse Social (HIS) em São Paulo com mais de dois anos uso. Os prédios selecionados pertencem ao Programa de Arrendamento Residencial (PAR) da Caixa Econômica Federal (CEF) em convênio com a Prefeitura da Cidade de São Paulo (PMSP) e suas unidades habitacionais são arrendadas a famílias com renda mensal entre três e seis salários mínimos. Na pesquisa são levantadas as dificuldades existentes neste período relacionadas aos aspectos sociais e econômicos dos moradores, assim como aos aspectos físicos e arquitetônicos do edifício. A metodologia utilizada inclui levantamento bibliográfico, entrevistas com os agentes responsáveis pela execução do programa habitacional e com os moradores dos edifícios. Após análise dos principais fatos que caracterizam a gestão pós-ocupação dos prédios, são apontadas as possíveis razões para as dificuldades encontradas na gestão. Destaca-se a falta de um trabalho social contínuo que monitore as relações sociais existentes no condomínio e que garanta a permanência da população no programa. Como resultado final do estudo são elencadas algumas alternativas para buscar a minimização dos problemas.

Palavras-chave: edifícios (reabilitação); habitação popular; administração. 


\section{ABSTRACT}

This work verifies the positive and negative aspects that exist in the post-occupancy management of five buildings that have been renovated for use as affordable housing in São Paulo, and have been in use for more than two years. The selected buildings are part of the Programa de Arrendamento Residencial (PAR) (Residential Rental Program) of the Caixa Econômica Federal (CEF) savings bank, in partnership with the São Paulo City Hall (PMSP), and the residential units are rented to families with a monthly income of three to six minimum salaries. The research investigates the difficulties that exist in this period, in relation to the residents' social and economic aspects, as well as the physical and architectural aspects of the building. The methodology used includes a bibliographic review, interviews with the agents responsible for carrying out the residential program, and residents of the buildings. After analyzing the main facts which characterize the post-occupancy management of the buildings, possible reasons for the difficulties experienced in the management are indicated. The need is highlighted, for a continual social work, to monitor the existing social relations in the building and ensure that the population stays in the program. As the final result of the study, some alternatives are listed aimed at minimizing the problems.

Key words: buildings (rehabilitation); affordable housing; management. 


\section{LISTA DE ILUSTRAÇÕES}

Figura 2.1 - Fluxo ilustrativo representando as interfaces entre os agentes dentro do Programa de Arrendamento Residencial.

Figura 3.1 - O contexto do edifício e as características específicas o local e dos usuários. 58

Figura 3.2 - Implantação geral do conjunto habitacional Zezinho Magalhães. 71

Figura 3.3 - Vista do conjunto habitacional Zezinho Magalhães. 72

Figura 3.4 - Imagem das freguesias do conjunto habitacional Zezinho Magalhães. 72

Figura 3.5 - Planta do pavimento tipo do edifício Santa Cecília A... 74

Figura 3.6 - Imagens da implantação e elevação do projeto Olaria. 76

Figura 3.7 - Imagens ilustrativas do projeto arquitetônico do Residencial Parque do Gato: perspectiva e corte.

Figura 4.1 - Imagem dos empreendimentos estudados. Da esquerda para direita: Maria Paula, Riskallah Jorge, Fernão Salles, Olga Benário e Labor.

Figura 4.2 - Localização da cidade de São Paulo e edifício Maria Paula......

Figura 4.3 - Elevação frontal e Cortes do edifício Maria Paula. 92

Figura 4.4 - Planta do subsolo e do pavimento térreo do edifício Maria Paula. 92

Figura 4.5 - Planta do pavimento tipo do edifício Maria Paula.. 93

Figura 4.6 - Detalhe divisão de cômodos do pavimento tipo do edifício Maria Paula. 102

Figura 4.7 - Proposta de lavanderia coletiva do edifício Maria Paula. 103

Figura 4.8 - Localização da cidade de São Paulo e do edifício Riskallah Jorge. 105

Figura 4.9 - Localização da cidade de São Paulo e do edifício Fernão Salles. 114

Figura 4.10 - Localização da cidade de São Paulo e do edifício Olga Benário. 120

Figura 4.11 - Planta do pavimento tipo do edifício Olga Benário com indicação das aberturas.

Figura 4.12 - Localização da cidade de São Paulo e do edifício Labor............................. 128

Figura 4.13 - Fachada lateral e frontal do edifício Labor. ................................................. 129

Figura 4.14 - Planta do pavimento tipo do edifício Labor. ............................................... 130

Figura 5.1 - Fluxo ilustrativo representando estrutura atual da gestão dos edifícios reabilitados do PAR.

Figura 5.2 - Fluxo ilustrativo representando as novas áreas de trabalho das administradoras de condomínios sociais. 


\section{LISTA DE FOTOS}

Foto 3.1 - Edifício Pirineus no ano em que foi entregue aos moradores............................ 73

Foto 3.2 - Edifício Pirineus cinco anos após a entrega. .................................................. 73

Foto 3.3 - Detalhes da conservação da fachada do edifício Pirineus.................................. 74

Foto 3.4 - Imagens do conjunto Olaria após quatro anos de ocupação.............................. 77

Foto 3.5 - Residencial Parque do Gato no ano de entrega aos moradores. ........................ 79

Foto 3.6 - Residencial Parque do Gato quatro anos após a entrega. ……......................... 79

Foto 3.7 - Imagem do Residencial Parque do Gato quatro anos após a entrega. ............... 79

Foto 4.1 - Fachada lateral do edifício Maria Paula. .......................................................... 90

Foto 4.2 - Fachada do edifício Maria Paula ..................................................................... 90

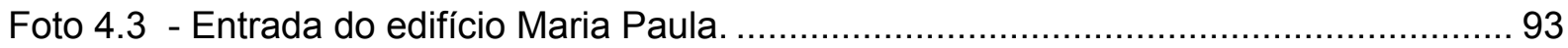

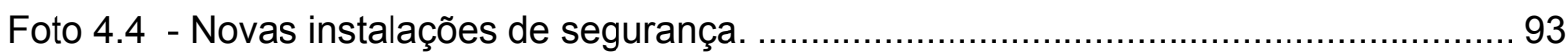

Foto 4.5 - Imagens da entrada do edifício Maria Paula................................................... 95

Foto 4.6 - Detalhe da janela "bay window" do edifício Maria Paula ................................... 102

Foto 4.7 - Lavanderia coletiva do edifício Maria Paula................................................... 103

Foto 4.8 - Imagens da fachada do edifício Riskallah Jorge ............................................ 104

Foto 4.9 - Detalhes das esquadrias e fachada do edifício Riskallah Jorge. ....................... 106

Foto 4.10 - Hall de entrada do edifício Riskallah Jorge. .............................................. 107

Foto 4.11 - Salão comunitário do edifício Riskallah Jorge ............................................ 107

Foto 4.12 - Imagens das áreas comuns e elevador do edifício Riskallah Jorge. .............. 110

Foto 4.13 - Imagens da fachada do edifício Fernão Salles. ........................................... 113

Foto 4.14 - Imagens das áreas comuns do edifício Fernão Salles................................... 115

Foto 4.15 - Imagens da fachada do edifício Olga Benário. .......................................... 119

Foto 4.16 - Imagens internas das unidades habitacionais do edifício Olga Benário.......... 126

Foto 4.17 - Imagens da fachada do edifício Labor. ....................................................... 127

Foto 4.18 - Imagens das áreas comuns externas do edifício Labor................................ 129

Foto 4.19 - Imagens das áreas comuns internas do edifício Labor................................ 133 


\section{LISTA DE GRÁFICOS}

Gráfico 2.1 - Distribuição do déficit habitacional urbano segundo grandes regiões do Brasil 2005.

Gráfico 2.2 - Porcentagem da população urbana do país $\mathrm{x}$ déficit habitacional por grandes regiões brasileiras -2005 .

Gráfico 2.3 - Déficit habitacional urbano, por faixas de renda média familiar - 2000/ 2005. 25

Gráfico 3.1 - Composição das despesas em um condomínio. .......................................... 47

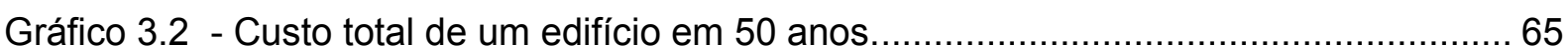

Gráfico 4.1 - Porcentagem de problemas por itens construtivos nas unidades e áreas comuns do edifício Maria Paula

Gráfico 4.2 - Porcentagens de problemas por itens construtivos nas unidades e áreas comuns do edifício Riskallah Jorge..

Gráfico 4.3 - Problemas das unidades habitacionais por número de solicitações no edifício Labor.

Gráfico 4.4 - Problemas nas áreas comuns por número de solicitações no edifício Labor.135 


\section{LISTA DE TABELAS}

Tabela 2.1 - Agentes envolvidos no Programa de Arrendamento Residencial (PAR) ......... 37

Tabela 4.1 - Dados gerais do edifício Maria Paula .................................................... 90

Tabela 4.2 - Dados gerais da gestão do edifício Maria Paula .......................................... 97

Tabela 4.3 - Dados gerais do edifício Riskallah Jorge .................................................. 104

Tabela 4.4 - Dados gerais da gestão do edifício Riskallah Jorge................................... 108

Tabela 4.5 - Dados gerais do edifício Fernão Salles.................................................... 113

Tabela 4.6 - Dados gerais da gestão do edifício Fernão Salles..................................... 116

Tabela 4.7 - Dados gerais do edifício Olga Benário...................................................... 119

Tabela 4.8 - Dados gerais da gestão do edifício Olga Benário. ...................................... 123

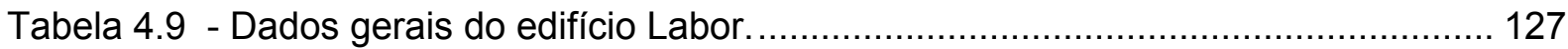

Tabela 4.10 - Dados gerais da gestão do edifício Labor. ............................................... 132 


\section{LISTA DE ABREVIATURAS E SIGLAS}

\begin{tabular}{|c|c|}
\hline AABIC & $\begin{array}{l}\text { Associação das Administradoras de Bens Imóveis e Condomínios de } \\
\text { São Paulo }\end{array}$ \\
\hline AGO & Assembléia Geral Ordinária \\
\hline AVC & Associação Viva o Centro \\
\hline CASFIG & $\begin{array}{l}\text { Coordenação de Âmbito Social e Financeiro das Habitações Sociais de } \\
\text { Guimarães }\end{array}$ \\
\hline $\mathrm{CDHU}$ & Companhia de Desenvolvimento Habitacional Urbano \\
\hline CECAP & Companhia Estadual de Casas Populares \\
\hline CEF & Caixa Econômica Federal \\
\hline CMMAD & Comissão Mundial sobre Meio Ambiente e Desenvolvimento \\
\hline CNPJ & Cadastro Nacional de Pessoas Jurídicas \\
\hline $\mathrm{COHAB}$ & Companhia Metropolitana de Habitação \\
\hline CONDEPHAAT & $\begin{array}{l}\text { Conselho de Defesa do Patrimônio Histórico, Arqueológico, Artístico e } \\
\text { Turístico }\end{array}$ \\
\hline DEM & Partido Democratas \\
\hline EPUSP & Escola Politécnica da Universidade de São Paulo \\
\hline FAR & Fundo de Arrendamento Residencial \\
\hline FINEP & Financiadora de Estudos e Projetos \\
\hline FIPE & Fundação Instituto de Pesquisas Econômicas \\
\hline FJP & Fundação João Pinheiro \\
\hline GIDUR & Gerência de Filial de Apoio ao Desenvolvimento Urbano \\
\hline GILIE & Gerência de Alienação de Bens e Imóveis \\
\hline GPO & Gestão Pós-Ocupação \\
\hline GTL & Gabinetes Técnicos Locais \\
\hline HABI & Superintendência de Habitação Popular \\
\hline HIS & Habitação de Interesse Social \\
\hline HMP & Habitação de Mercado Popular \\
\hline IBGE & Instituto Brasileiro de Geografia e Estatística \\
\hline IEE & Instituto de Estudos Especiais \\
\hline IPT & Instituto de Pesquisas Tecnológicas \\
\hline IPTU & Imposto Predial Territorial Urbano \\
\hline MMC & Movimento de Moradia do Centro \\
\hline NBF & Norma Brasileira \\
\hline
\end{tabular}




$\begin{array}{ll}\text { ONU } & \text { Organização das Nações Unida } \\ \text { PAC } & \text { Programa de Atuação em Cortiços } \\ \text { PAR } & \text { Programa de Arrendamento Residencial } \\ \text { PMSP } & \text { Prefeitura da Cidade de São Paulo } \\ \text { PRIH } & \text { Perímetros de Reabilitação Integrada do Habitat } \\ \text { PSDB } & \text { Partido da Social Democracia Brasileira } \\ \text { PT } & \text { Partido dos Trabalhadores } \\ \text { REFER } & \text { Fundação Rede Ferroviária de Seguridade Social } \\ \text { SEHAB } & \text { Secretaria de Habitação } \\ \text { TTS } & \text { Trabalho Técnico Social } \\ \text { UCSAL } & \text { Universidade Católica de Salvador } \\ \text { UFRJ } & \text { Universidade Federal do Rio de Janeiro } \\ \text { ULC } & \text { Unificação das Lutas de Cortiços } \\ \text { USP } & \text { Universidade de São Paulo } \\ \text { ZEIS } & \text { Zona Especial de Interesse Social }\end{array}$




\section{SUMÁRIO}

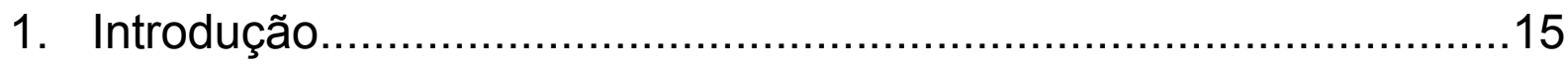

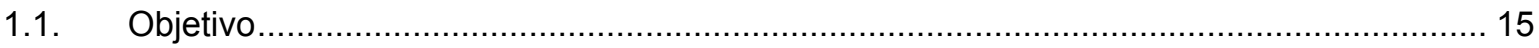

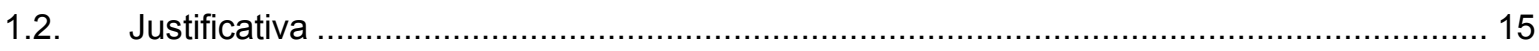

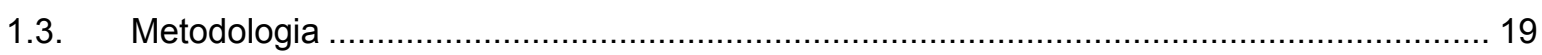

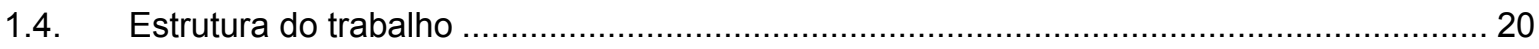

2. Política habitacional e a reabilitação de edifícios ..........................22

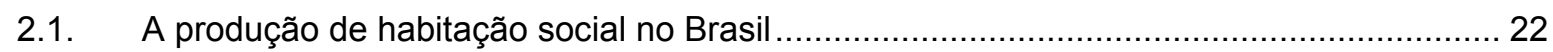

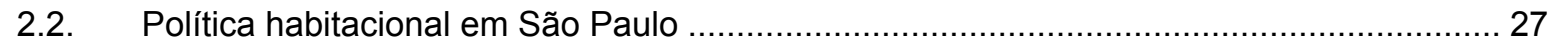

2.3. O procedimento para reabilitação de edifícios em São Paulo .............................................. 35

3. Gestão pós-ocupação em edifícios verticalizados .........................40

3.1. Gestão pós-ocupação em edifícios verticalizados residenciais ........................................ 41

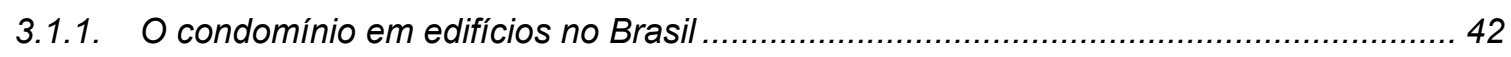

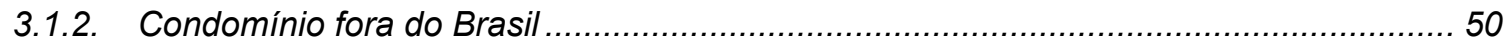

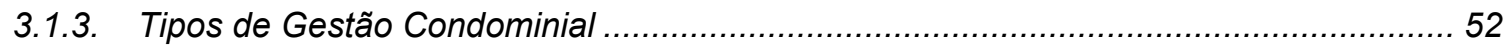

3.1.4. Relações de vizinhança em condomínios ................................................................. 55

3.2. Gestão Pós-Ocupação em edifícios reabilitados para HIS ................................................. 57

3.2.1. Aspectos sociais e culturais da população moradora................................................. 61

3.2.2. Aspectos econômico-financeiros da população moradora ............................................ 63

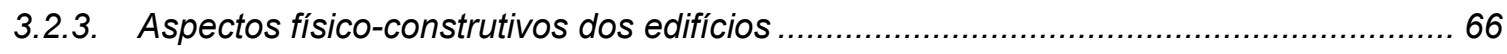

3.2.4. Aspectos arquitetônicos e urbanísticos dos edifícios .................................................. 68

3.2.5. Exemplos de gestão pós-ocupação em edifícios de São Paulo...................................... 70

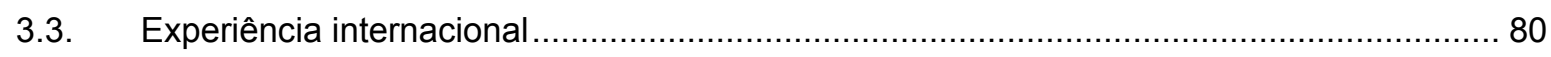

3.3.1. A experiência portuguesa em gestão pós-ocupação de edifícios ................................ 81

4. Edifícios reabilitados em São Paulo voltados para HIS ..................88

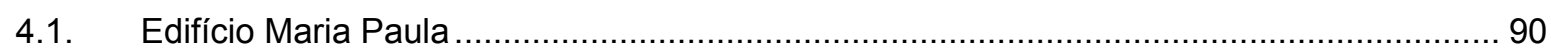

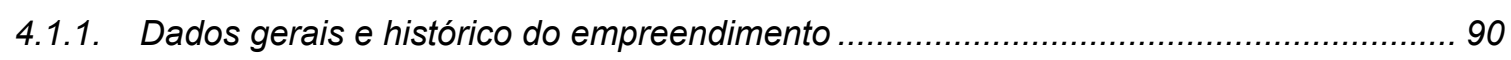

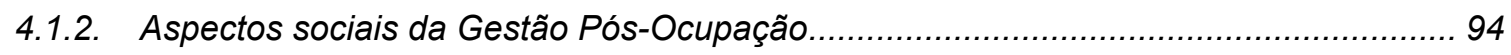

4.1.3. Aspectos econômicos da Gestão Pós-Ocupação ......................................................... 98

4.1.4. Aspectos físico-construtivos da Gestão Pós-Ocupação ........................................... 100

4.1.5. Aspectos arquitetônicos e urbanísticos da Gestão Pós-Ocupação ............................... 102

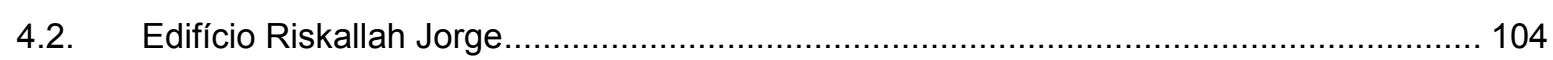

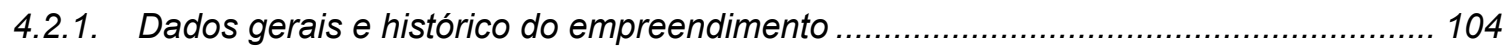

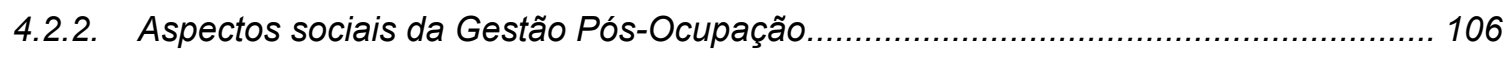

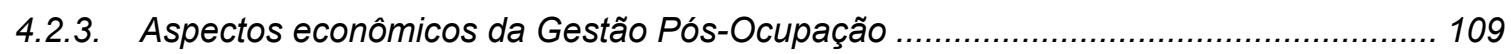

4.2.4. Aspectos físico-construtivos da Gestão Pós-Ocupação ........................................... 110 
4.2.5. Aspectos arquitetônicos e urbanísticos da Gestão Pós-Ocupação ............................... 112

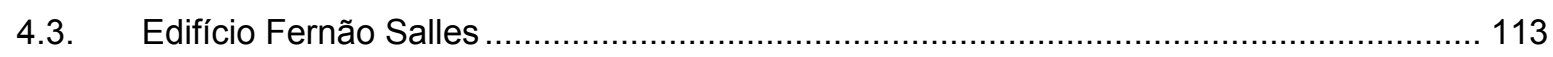

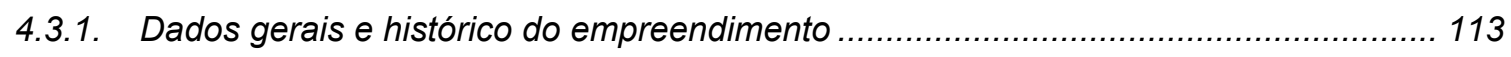

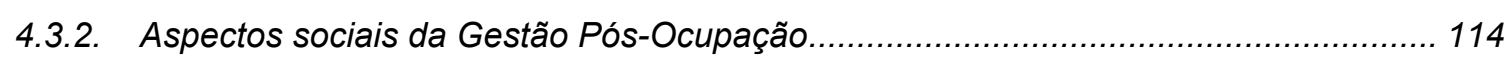

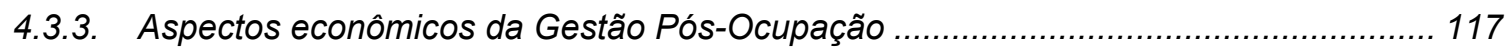

4.3.4. Aspectos físico-construtivos da Gestão Pós-Ocupação............................................... 117

4.3.5. Aspectos arquitetônicos e urbanísticos da Gestão Pós-Ocupação................................ 118

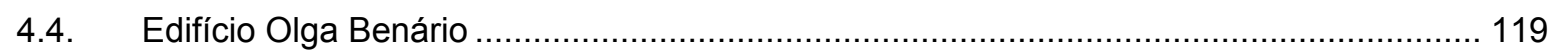

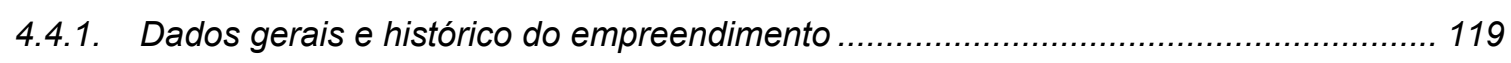

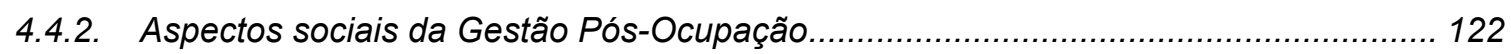

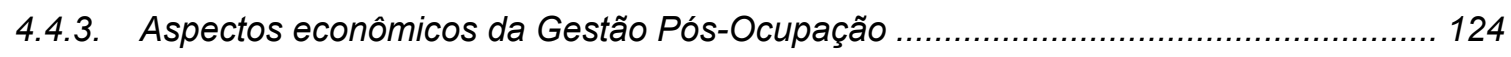

4.4.4. Aspectos físico-construtivos da Gestão Pós-Ocupação................................................ 124

4.4.5. Aspectos arquitetônicos e urbanísticos da Gestão Pós-Ocupação .............................. 125

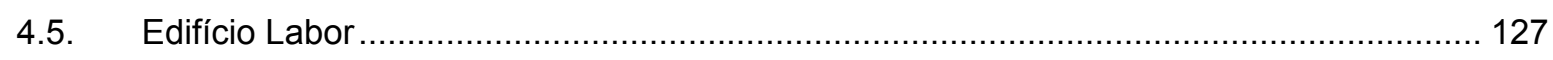

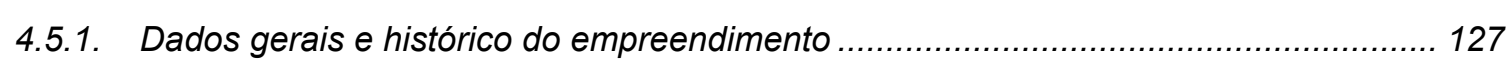

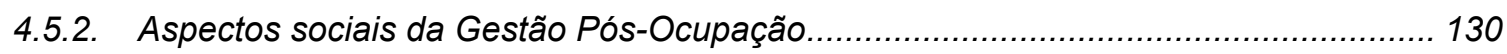

4.5.3. Aspectos econômicos da Gestão Pós-Ocupação ..................................................... 133

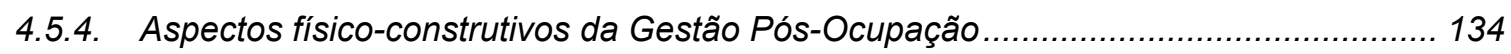

4.5.5. Aspectos arquitetônicos e urbanísticos da Gestão Pós-Ocupação .............................. 136

5. Análise da pesquisa de campo..........................................137

5.1. Razões que desencadearam problemas na gestão pós-ocupação dos edifícios .............. 138

5.2. Alternativas visando à minimização dos problemas na gestão pós-ocupação em edifícios

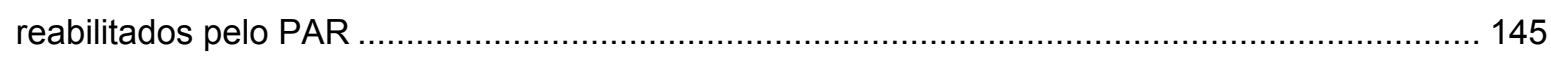

6. Considerações finais .........................................................152

7. Referências bibliográficas .....................................................156 


\section{Introdução}

\subsection{Objetivo}

O objetivo da pesquisa é identificar e analisar as dificuldades existentes na etapa de uso em cinco edifícios reabilitados para Habitação de Interesse Social (HIS) localizados na cidade de São Paulo, e apontar as possíveis razões que desencadearam os problemas.

\subsection{Justificativa}

Atualmente, uma das principais dificuldades encontradas em centros urbanos de grandes cidades é o esvaziamento populacional das áreas centrais, onde há amplo capital social investido.

Conforme analisa Bomfim (2004), a vacância ${ }^{1}$ do centro histórico de São Paulo, por exemplo, é de $18 \%$ de área construída, sendo que a maioria dos espaços edificados vazios é encontrada em edifícios verticalizados, com um período de desocupação superior a um ano e com necessidade de reformas para se tornarem operacionais novamente.

Este aumento de áreas vazias em virtude do deslocamento da população provoca uma subutilização da infra-estrutura urbana e do sistema viário público existente nas áreas centrais (BOMFIM, 2004).

Ao mesmo tempo, paradoxalmente, estas cidades apresentam graves problemas ligados à falta de moradia para uma parcela da população, que passa a ocupar regiões periféricas caracterizadas pela falta de infra-estrutura urbana e de dinâmicas sociais em torno da moradia, tais como saneamento básico, segurança, coleta de lixo, escola, trabalho, lazer, cultura etc (BARRRETO SILVA, 2000).

Em São Paulo, a partir da década de 90, começaram a ser elaborados alguns projetos de intervenções em edifícios públicos na região central com o intuito de reverter este quadro de esvaziamento populacional (REABILITA, 2007).

\footnotetext{
${ }^{1}$ A vacância é entendida como a relação entre todos os espaços construídos vazios e o total de espaços construídos em uma determinada área (BOMFIM, 2004)
} 
No mesmo período, os movimentos de moradia, atuantes desde as décadas de 70 e 80 no município, passaram a organizar sua atuação na área central, ocupando os edifícios vazios localizados na região como forma de pressionar o governo do município e do Estado. Além da produção de novas unidades habitacionais, consolidou-se a reivindicação pelo direito de permanecer no centro, ou seja, pela proximidade com a região de infra-estrutura consolidada, com equipamentos públicos de saúde, educação, lazer, bem como com pólos de empregos (BARRETO SILVA, 2006).

Neste momento foram colocadas em pauta as propostas de reabilitação dos inúmeros edifícios vazios ou subutilizados existentes na região para Habitação de Interesse Social (HIS), além da criação de linhas de financiamento adequadas para atender à demanda habitacional existente (BARRETO SILVA, 2006).

É importante ressaltar que o termo reabilitação aqui empregado refere-se ao processo pelo qual o imóvel ou o bem urbanístico pode ser recuperado, e permeia vários níveis de intervenções, alcançando desde pequenas ações como pintura e recuperação de alguns sistemas, até a reconstituição da edificação, considerando não só os imóveis ligados ao patrimônio histórico cultural, como também os imóveis que constituem a malha urbana, sem valor histórico (REABILITA, 2007).

Entretanto, segundo Lopes (2006), a reabilitação de edifícios vazios deve fazer parte de uma grande política de reabilitação urbana, considerando-se a ação como uma estratégia de gestão urbana apoiada em diversos projetos que tem por finalidade dinamizar as condições de uma área, sem descaracterizá-la, porém garantindo a participação da comunidade local e preservando o patrimônio social.

As três esferas governamentais buscaram responder a essas reivindicações dos movimentos através da criação de planos e programas habitacionais que incluem a reabilitação de edifícios como alternativa.

No Brasil, o tema da reabilitação de edifícios é relativamente recente. O debate foi iniciado no final da década de 80 por meio da apresentação do projeto do Estatuto da Cidade $^{2}$. A partir deste momento, vários fatos contribuíram para o desenvolvimento da política, como o surgimento da Associação Viva o Centro (AVC), em 1991, o Laboratório Integrado de Cortiços ocorrido em 1999, os seminários "Habitação no Centro de São Paulo: Como viabilizar esta idéia?", em

\footnotetext{
${ }^{2}$ Lei Federal no $10.257 / 2001$
} 
2000, "Habitação em áreas centrais de Metrópoles Latino - Americanas", em 2004, o "Seminário Internacional de Reabilitação de Edifícios em Áreas Centrais", em 2006, entre outros.

Em meados de 2007, o Departamento de Engenharia de Construção Civil da Escola Politécnica da Universidade de São Paulo (EPUSP), em parceria com a Universidade Federal do Rio de Janeiro (UFRJ) e a Universidade Católica de Salvador (UCSAL), concluíram o projeto REABILITA, cujo financiamento foi realizado pela Financiadora de Estudos e Projetos (FINEP).

$\mathrm{O}$ projeto teve como objetivo principal colaborar para o entendimento do processo de reabilitação de edifícios para Habitação de Interesse Social (HIS), através de um trabalho de análise e sistematização de informações coletadas em três cidades brasileiras - São Paulo, Rio de Janeiro e Salvador. Com a finalização do projeto, foi publicado um relatório denominado "Diretrizes para a reabilitação de edifícios para HIS: as experiências em São Paulo, Salvador e Rio de Janeiro".

Todas as ações acima apresentadas, incluindo debates, pesquisas, seminários e ações dos agentes públicos e privados, sempre tiveram como objetivo principal a compreensão e domínio do processo de reabilitação de edifícios para HIS.

Entretanto, durante os estudos, algumas lacunas importantes puderam ser evidenciadas, propiciando um maior aprofundamento no tema.

Dentre elas a questão da gestão destes edifícios e dos novos moradores após a ocupação. Ou seja, de que maneira é feita a administração tanto da nova rede de relações sociais existentes no local criada pelos novos moradores, quanto da preservação e manutenção da edificação e suas áreas comuns? É possível garantir que estas pessoas conseguirão permanecer nas novas unidades habitacionais?

De acordo com o projeto REABILITA (2007), o processo de reabilitação de edifícios pode ser dividido em quatro grandes fases: Diagnóstico do imóvel; Elaboração de projeto; Planejamento e gestão da produção e, finalmente, Gestão da ocupação do edifício, cujo objetivo é a organização do processo de ocupação da edificação de forma a considerar as necessidades da população que será beneficiada, garantindo o acompanhamento social pelos órgãos públicos ou por agentes sociais envolvidos no processo (REABILITA, 2007). 
Até o momento, o Programa de Arrendamento Residencial (PAR) da Caixa Econômica Federal (CEF), responsável pela promoção destes edifícios reabilitados em São Paulo, não possui um trabalho de gestão pós-ocupação.

Conforme será descrito no capítulo três desta dissertação, a gestão pósocupação de um edifício ocorre no período da entrada dos moradores no prédio e deve ter como objetivo controlar todos os aspectos relacionados ao edifício e aos seus usuários, garantindo que as metas iniciais a que a edificação se propõe sejam cumpridas.

Por se tratar de prédios de habitação social, a gestão destes edifícios pode ser algo bem mais amplo do que um acompanhamento social. Deve englobar várias dimensões complementares, levando em conta principalmente os aspectos sociais e econômicos dos usuários, visando tanto à permanência dos moradores, quanto à presença do poder público no local (BARRETO SILVA, 2000).

Conforme analisa Cymbalista (2007), “(...) em edifícios sociais, o poder público deve assumir um papel de mediador, de capacitador para qualificar a vida condominial. É necessário um conhecimento das dificuldades enfrentadas nos empreendimentos, as necessidades de reparo no edifício pós-ocupação, a necessidade de organização dos moradores, ou seja, os processos sociais envolvidos na promoção da moradia".

De acordo com a conclusão apresentada pelo projeto REABILITA (2007) “(...) um fator importante a ser desenvolvido é o acompanhamento pós-execução, período em que os moradores recebem suas novas moradias. É fundamental que ocorra algum acompanhamento com as famílias, definindo e implementando modelos de gestão condominial, e também apresentando soluções para os futuros gastos de manutenção, uma vez que são situações novas, onde dificilmente as famílias conseguirão arcar com os custos existentes".

Considerando a importância da sustentabilidade das políticas de reabilitação de edifícios para HIS e a ausência de estudos e pesquisas sobre a gestão destes prédios e de seus moradores, o presente trabalho é proposto a fim de contribuir com o tema.

Serão identificadas as dificuldades existentes neste tipo de gestão a partir da análise de cinco empreendimentos reabilitados para HIS em São Paulo, com o objetivo de apontar tanto as razões que desencadearam os problemas, quanto 
algumas alternativas, visando à minimização das dificuldades na gestão pósocupação em edifícios reabilitados pelo PAR.

\subsection{Metodologia}

Para conduzir a pesquisa, a metodologia proposta foi dividida em três etapas:

- Levantamento bibliográfico;

- Pesquisa de campo;

- Análise das informações para elaboração da dissertação.

Para o levantamento bibliográfico foram consultados livros, teses e dissertações, artigos científicos, normas técnicas, além de publicações em jornais e revistas e Internet. As bibliotecas consultadas foram: biblioteca de Engenharia Civil da Escola Politécnica da Universidade de São Paulo (USP); biblioteca de Engenharia de Produção da Escola Politécnica da USP; biblioteca da Faculdade de Economia, Administração e Contabilidade da USP; biblioteca da Faculdade de Arquitetura e Urbanismo da USP (graduação e pós-graduação); biblioteca da Faculdade de Filosofia, Letras e Ciências Humanas da USP; biblioteca do Instituto de Pesquisas Tecnológicas do Estado de São Paulo; biblioteca da Pontifícia Universidade Católica de São Paulo.

Os temas abordados nas pesquisas foram: habitação de interesse social; conjuntos habitacionais verticalizados; reabilitação de edifícios vazios nos centros das grandes cidades; programas habitacionais; gestão; pós-ocupação; condomínio edilício; tipos de gestão condominial; manutenção; inadimplência; aspectos sociais, econômicos, físicos e urbanos que envolvem as HIS; e experiências nacionais e internacionais de gestão.

O início da pesquisa de campo ocorreu por meio de entrevistas não estruturadas com representantes dos órgãos relacionados ao processo de reabilitação de edifícios e à gestão. Foram feitas entrevistas com técnicos da CEF, 
PMSP, CDHU, assistentes sociais, administradoras de condomínio, construtoras e assessorias técnicas ${ }^{3}$.

Um ponto importante a ser destacado é o acompanhamento de um Trabalho Técnico Social (TTS), realizado em um empreendimento reabilitado no bairro do Belém, em São Paulo, recém entregue pela CEF no âmbito do PAR. Este acompanhamento permitiu maior contato com o trabalho social oferecido aos moradores do programa, além de permitir grande contato com os arrendatários.

Após as entrevistas com os técnicos, iniciou-se um levantamento dos dados referentes aos edifícios reabilitados selecionados como objeto de análise (Fernão Salles e Riskallah Jorge, na Sé; Olga Benário, no Belém; Maria Paula e Labor, na República). Os levantamentos foram baseados em entrevistas não estruturadas com os moradores, administradoras e representantes da CEF, além da elaboração de um relatório fotográfico e imagens gráficas. As conversas seguiram, dependendo do interlocutor (moradores, técnicos) pontos específicos e não foram dirigidas por um roteiro fixo de perguntas.

Após a sistematização de todo o material coletado, iniciou-se o processo de análise dos dados para elaboração da dissertação.

\subsection{Estrutura do trabalho}

O trabalho está desenvolvido ao longo de cinco capítulos, além da introdução, descritos a seguir.

No segundo capítulo, "Política habitacional e a reabilitação de edifícios", busca-se traçar um breve panorama histórico da política habitacional no Brasil e na cidade de São Paulo, focando as políticas relacionadas à HIS e à questão da reabilitação de edifícios verticalizados nos centros das grandes cidades. Adicionalmente, são apresentados o procedimento e os agentes envolvidos no Programa de Arrendamento Residencial (PAR) da Caixa Econômica Federal (CEF) para os edifícios reabilitados de São Paulo.

São apresentados no terceiro capítulo, "Gestão pós-ocupação em edifícios verticalizados", os conceitos básicos relativos ao tema da gestão pós-ocupação em

\footnotetext{
${ }^{3}$ Algumas entrevistas aqui citadas foram realizadas no âmbito do Projeto REABILITA em 2006.
} 
edifícios, bem como são detalhados os conceitos relacionados ao condomínio e os tipos de gestão condominial existentes. Na seqüência, são elencados os aspectos sociais, econômicos, físicos e urbanos que diferenciam a gestão pós-ocupação em edifícios reabilitados para HIS de outros edifícios. Em seguida, são apresentados como exemplo alguns edifícios que possuem aspectos positivos e negativos na gestão pós-ocupação. Por fim, é apresentada uma experiência internacional de gestão pós-ocupação para HIS implantada na cidade de Guimarães, em Portugal.

No quarto capítulo, "Edifícios reabilitados em São Paulo voltados para HIS", são apresentadas cinco experiências de reabilitação ocorridas na cidade de São Paulo, as quais são detalhadas inicialmente pelo histórico do empreendimento, seguido pelos dados gerais e imagens do projeto de reabilitação executado. Após este panorama geral, são elencados os principais fatos que caracterizaram a gestão pós-ocupação do edifício, desde a entrada dos moradores até os dias de hoje. Estes fatos foram classificados em função dos aspectos sociais, econômicos, físicoconstrutivos e urbanísticos envolvidos.

Por sua vez, no quinto capítulo, "Análise da pesquisa de campo" é realizada uma verificação detalhada dos dados relativos aos cinco empreendimentos apresentados no quarto capítulo, procurando identificar as principais razões que desencadearam problemas na gestão pós-ocupação dos prédios, assim como alternativas visando à minimização dos problemas na gestão pós-ocupação em edifícios reabilitados pelo PAR.

No sexto e último capítulo, "Considerações finais", realiza-se uma síntese dos principais pontos levantados na dissertação, e são apresentadas as conclusões do trabalho. Além disso, são identificadas as necessidades de aprofundamento em algumas questões relacionadas ao tema que foram levantadas durante o processo da pesquisa.

Após as considerações finais, são apresentadas as referências bibliográficas utilizadas para elaboração do presente trabalho. 


\section{Política habitacional e a reabilitação de edifícios}

Buscando contextualizar a existência dos edifícios reabilitados em São Paulo e conseqüentemente sua gestão dentro do programa habitacional, será traçado a seguir um breve panorama histórico da política habitacional no Brasil, focando as políticas relacionadas à habitação de interesse social e à questão da reabilitação de edifícios verticalizados nos centros das grandes cidades.

Será analisada a questão habitacional especificamente na cidade de São Paulo, identificando o contexto que propiciou o início da política de reabilitação de edifícios vazios.

Finalmente, serão analisados os agentes envolvidos e as fases do processo da reabilitação viabilizado pelo Programa de Arrendamento Residencial (PAR).

\subsection{A produção de habitação social no Brasil}

O Brasil é um país com uma história urbana recente, caracterizada por uma ocupação territorial fortemente vinculada à exploração da produção agroexportadora (Maricato, 2001). Em 1940, a população urbana representava $31,2 \%$ da população total do país. Já em 1960, representava 44,7\%; em 1970, 55,9\%, chegando a 78\% em 1996. De 1960 a 2000 a população urbana aumentou de 31 milhões para 137 milhões, ou seja, as cidades receberam aproximadamente 106 milhões de novos moradores nesse período (IBGE, 2000).

De acordo com publicação realizada pela Fundação João Pinheiro (2006), o déficit habitacional ${ }^{4}$ no Brasil até 2005 era de aproximadamente 7.900 .000 moradias,

\footnotetext{
${ }^{4} \mathrm{O}$ conceito de déficit habitacional está ligado diretamente às deficiências do estoque de moradias. Os componentes do déficit habitacional, de acordo com a Fundação, são: a habitação precária, a coabitação familiar e o ônus excessivo com aluguel. Entende-se por habitação precária moradias que não possuem condições de habitabilidade devido à precariedade das construções (aquelas que apresentam desconforto e risco de contaminação por doenças em decorrência das suas condições de insalubridade) ou em virtude dos desgastes da estrutura física onde a depreciação de domicílios está relacionada ao pressuposto de que há um limite para a vida útil de um imóvel a partir do qual são exigidos reparos em sua estrutura física, visando à conservação de sua habitabilidade (toma-se 50 anos de construção como o limite que define a necessidade de reposição do estoque). Já a coabitação familiar compreende famílias que vivem junto a outra família em um mesmo domicílio e as que vivem em cômodos que, de acordo com definição do IBGE, são definidos como "domicílios particulares compostos por um ou mais aposentos localizados em casa de cômodo, cortiço, cabeçade-porco etc". Já o ônus excessivo por aluguel corresponde ao número de famílias urbanas com
} 
considerando as áreas urbanas e rurais, o que corresponde a $14,9 \%$ do total do estoque de domicílios (FJP, 2006). As áreas urbanas possuem maior concentração do déficit, com aproximadamente 6.400 .000 domicílios, dos quais $34,7 \%$, ou 2.200.000, localizam-se nas regiões metropolitanas (FJP, 2006).

O estudo revela que na região sudeste deve-se ressaltar os Estados de São Paulo (1.510.463), o maior déficit em números absolutos do país, Minas Gerais (682.432) e Rio de Janeiro (580.624), além das regiões metropolitanas de São Paulo (738.334) e Rio de Janeiro (442.153). Na região nordeste, os destaques são para Bahia (657.555), Maranhão (539.571), Pernambuco (427.923) e Ceará (424.321). Quanto às demais unidades da Federação, sobressaem apenas o Pará (427.327) e Amazonas (212.487) na região norte, Rio Grande do Sul (368.233) e Paraná (325.681) na região sul e Goiás (220.198) na região centro-oeste (FJP, 2006). O gráfico abaixo (Gráfico 2.1) representa os dados levantados:

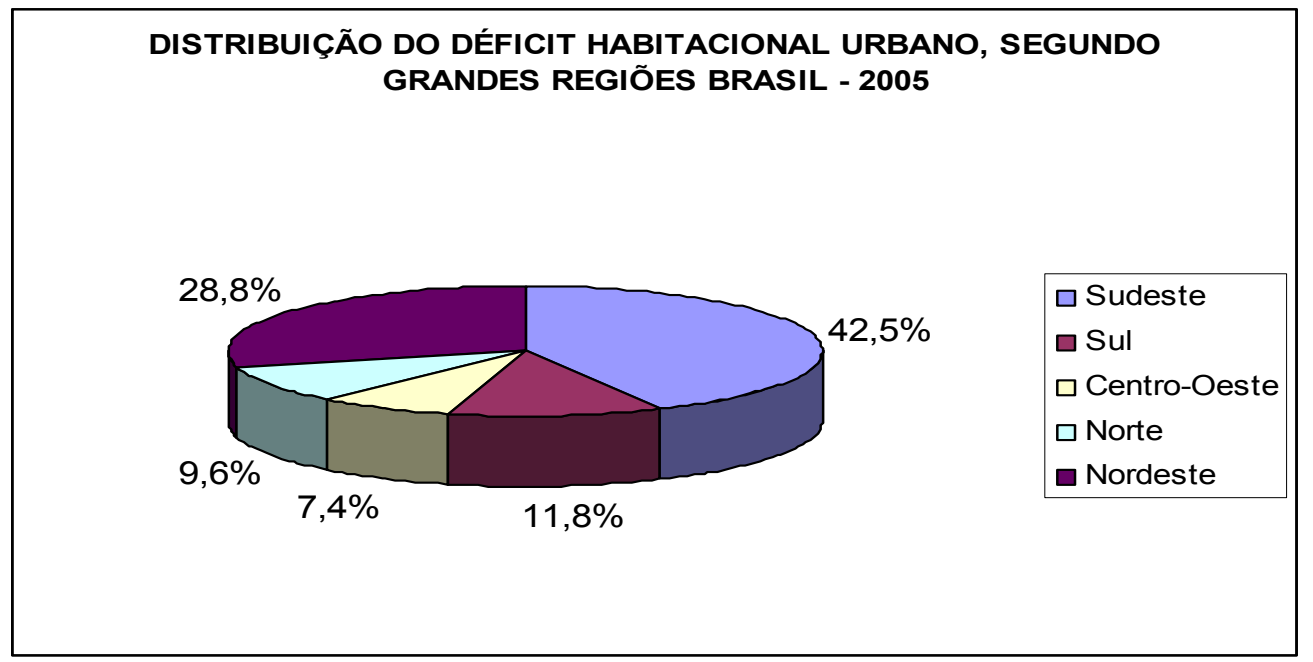

Gráfico 2.1 Distribuição do déficit habitacional urbano segundo grandes regiões do Brasil 2005.

Fonte: Fundação João Pinheiro, 2006.

O gráfico a seguir (Gráfico 2.2) mostra a relação entre a porcentagem da população de cada região do país em relação ao déficit habitacional estimado para a região, demonstrando que a região sudeste possui o maior déficit ao mesmo tempo em que concentra o maior número de habitantes na área urbana. 


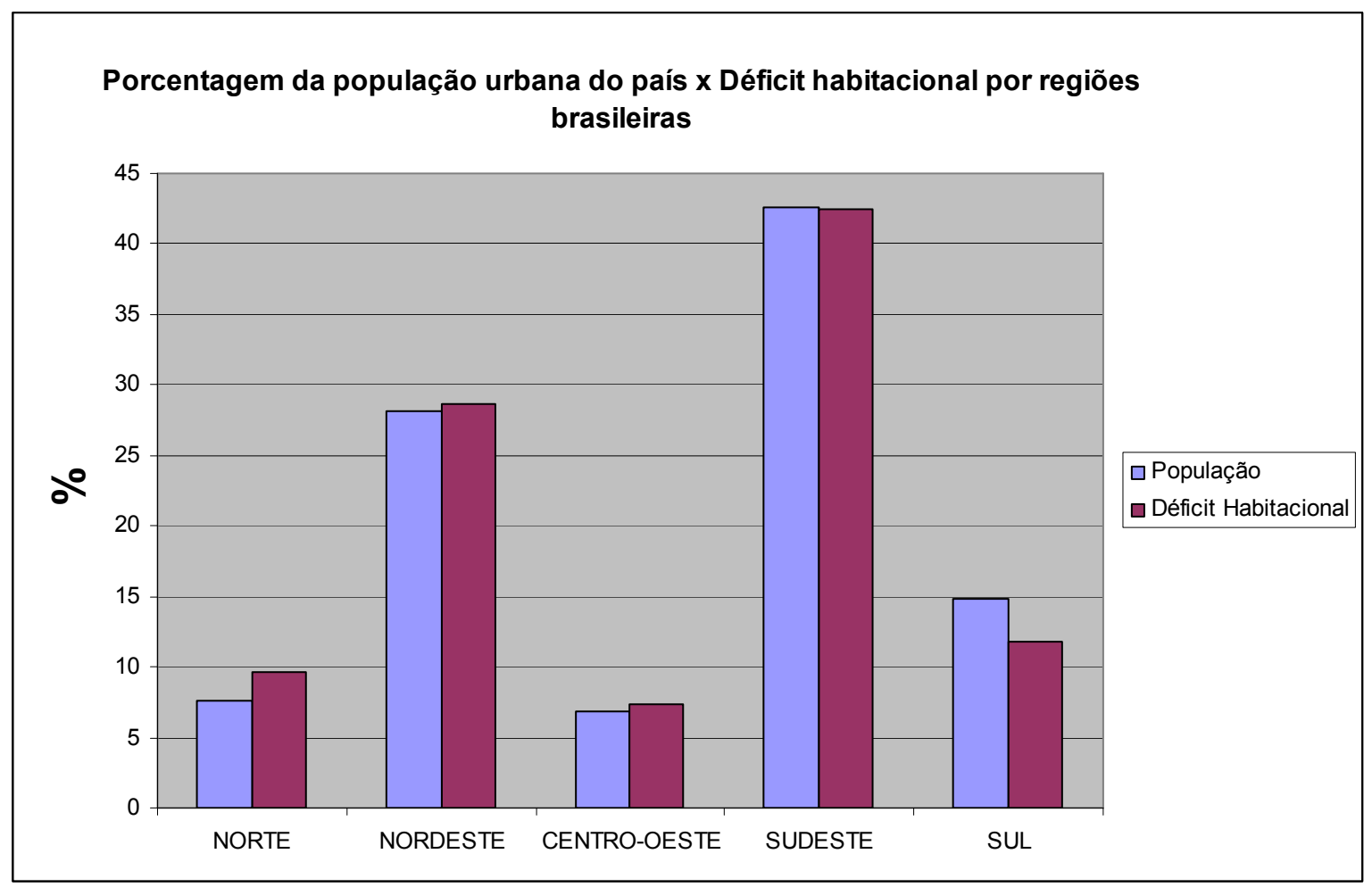

Gráfico 2.2 Porcentagem da população urbana do país $\mathrm{x}$ déficit habitacional por grandes regiões brasileiras - 2005.

Fonte: Fundação João Pinheiro, 2006; IBGE, 2008.

Uma análise importante do déficit é a que relaciona as faixas de rendimento médio mensal familiar. Como ilustra o gráfico abaixo (Gráfico 2.3), famílias de todas as regiões do país que recebem até três salários mínimos são as mais carentes em habitação, evidenciando a falta de programas habitacionais por parte do poder público para esta camada da população, que não possui recursos para comprar ou alugar uma residência no mercado privado, optando muitas vezes pelas habitações informais, tais como cortiços e favelas. 


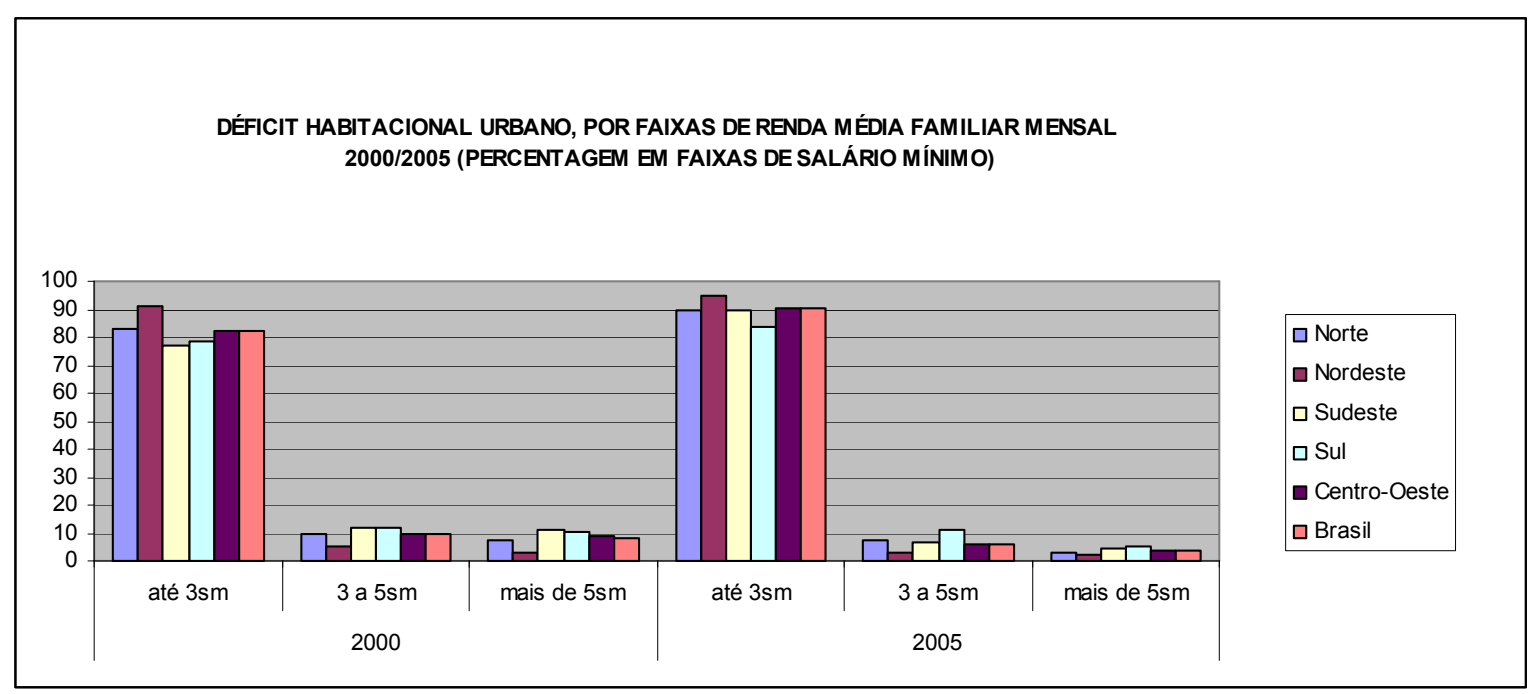

Gráfico 2.3 Déficit habitacional urbano, por faixas de renda média familiar - 2000/ 2005. Fonte: Fundação João Pinheiro, 2006; IBGE, 2008.

A ausência de ofertas habitacionais suficientes para esta demanda acarreta um grande crescimento desta população em favelas e loteamentos irregulares nas periferias das cidades, onde surgem grandes problemas ligados às condições de habitabilidade dos moradores. As áreas periféricas, na maioria das vezes, são desprovidas de infra-estrutura básica, como água, energia elétrica, esgoto canalizado, transporte público e serviços essenciais, como postos médicos, estruturas de lazer, entre outros, o que agrava ainda mais a situação.

Ao mesmo tempo, diversas cidades apresentam um esvaziamento populacional das regiões mais consolidadas, como as áreas centrais, onde há amplo capital social investido. Os centros possuem uma infra-estrutura consolidada, acessibilidade e maiores oportunidades de trabalho em relação a outras regiões das cidades. Porém, a partir da década de 70 , os distritos vêm perdendo moradores, especialmente famílias de renda média e alta, fato evidenciado pela baixa densidade populacional em alguns desses bairros e pela grande quantidade de domicílios e edifícios vazios ou subutilizados (BARRETO SILVA, 2000). Entre as razões, estão a deterioração da qualidade de vida e a busca por bairros residenciais e condomínios fechados.

Um dos desafios à gestão destas cidades brasileiras, bem como de outras localidades de fora do país, é a ocupação destes imóveis vagos ou subutilizados localizados nestas áreas (REABILITA, 2007). 
Cidades de diversos países como França, Itália e Portugal adotam ações direcionadas à reabilitação de edifícios como forma de garantir parte destes espaços vazios e ou degradados para habitação de interesse social. Estas ações buscam, em geral, garantir a reabilitação de áreas centrais a partir da permanência da população ali residente. A reabilitação vinculada à habitação de interesse social não se limita à problemática da execução de obra ou análise de créditos, pois abrange a reabilitação de espaços urbanos (REABILITA, 2007).

Em São Paulo, segundo analisa Bomfim (2004), desde a década de 80 o centro tem apresentado uma redução no número de moradores e domicílios ocupados, ao mesmo tempo em que registra um aumento da presença de domicílios vagos.

Neste contexto, os movimentos sociais de luta por moradia passam a ocupar os edifícios vazios nos centros, buscando expor os problemas da falta de habitação que atinge a população de baixa renda, assim como as péssimas condições de habitabilidade das moradias deste grupo social (BOMFIM, 2004). Os movimentos reivindicam a implementação de políticas habitacionais de interesse social nas áreas centrais, onde são encontrados os serviços públicos e a infra-estrutura necessária para esta população, diferentemente dos conjuntos construídos em glebas afastadas na periferia, onde a infra-estrutura básica é inexistente.

Como conseqüência da constante ofensiva destes movimentos, são elaborados programas de reabilitação de áreas centrais no país. Segundo o Ministério das Cidades (2005), "a reabilitação das áreas urbanas centrais por meio da recuperação do estoque imobiliário procura promover o uso e a ocupação democrática e sustentável dos centros urbanos, propiciando o acesso à habitação com a permanência e a atração de população de diversas classes sociais, principalmente as de baixa renda".

Entretanto, as intervenções em áreas centrais com programas para HIS são complexas, uma vez que existem diversos entraves. Entre eles estão os problemas fundiários, o alto preço dos imóveis ofertados pelos proprietários e a especulação gerada pelo simples anúncio de intervenções futuras (REABILITA, 2007).

Há ainda a falta de legislação e instrumentos urbanísticos adequados, conflitos entre as diretrizes de preservação do patrimônio histórico e as novas 
necessidades comportamentais e tecnológicas, a falta de adequação do setor da construção civil para a reabilitação e a falta de mão-de-obra capacitada.

Além disso, de uma maneira mais ampla, a falta de uma política habitacional clara e adequada para atendimento e produção de HIS nas áreas centrais, e a falta de uma gestão urbana que busque a sustentabilidade social e econômica, também interferem diretamente nas intervenções (REABILITA, 2007).

O conceito de sustentabilidade é aqui utilizado com um enfoque da sustentabilidade urbana. De acordo com Acserald (1999), “(...) a noção de sustentabilidade urbana é centrada na reconstituição da legitimidade das políticas urbanas e remete a sustentabilidade à construção de pactos políticos capazes de reproduzir suas próprias condições de legitimidade e assim dar sustentação a políticas urbanas que possam adaptar a oferta de serviços urbanos às demandas qualitativas e quantitativas da população".

A reabilitação deve ser verificada em várias escalas, que vão do edifício até a sua relação com o entorno. Como processo, a reabilitação e suas diretrizes devem ser continuamente revistas e atualizadas, garantindo a presença e permanência de grupos sociais de baixa renda na área central para melhorar o processo de reabilitação (REABILITA, 2007).

\subsection{Política habitacional em São Paulo}

Na Região Metropolitana de São Paulo, ainda segundo a Fundação João Pinheiro, em 2005, o déficit habitacional quantitativo atingia um total de 740 mil unidades. Ou seja, aproximadamente 750 mil famílias na Grande São Paulo moravam em situação precária por ausência de oportunidades habitacionais.

Segundo estudos realizados, o município de São Paulo, possui cerca de $11 \%$ da sua população morando em favelas - o equivalente a 1,16 milhões de pessoas (Centro de Estudos da Metrópole, 2002), 600 mil em cortiços (FIPE, 1994) e cerca de um milhão vivendo em áreas de mananciais (IBGE, 2000). Outro dado importante são os loteamentos irregulares ou clandestinos, onde cerca de 1,5 milhão de pessoas vivem com renda abaixo de cinco salários mínimos (Plano Municipal de Habitação, 2002). 
As regiões que vêm apresentando maiores crescimentos populacionais no município são as periferias, que de forma geral são as áreas com mais restrições à ocupação devido à existência de áreas de proteção ambiental e a falta de infraestrutura, enquanto as regiões que apresentam melhor infra-estrutura e equipamentos, como a região central, vêm perdendo população (CYMBALISTA, 2007).

Segundo o IBGE, em 2000, o número de domicílios vagos era de aproximadamente 250 mil no município e 420 mil na região metropolitana de São Paulo ${ }^{5}$. De alguma forma, a existência destes imóveis poderia minimizar a situação de carência habitacional de grande parte da população.

De acordo com Bomfim (2004), no centro histórico de São Paulo (Sé e República), segundo os dados obtidos por meio da pesquisa de campo, a vacância é estimada em $18 \%$ de área construída vazia, na qual a maioria dos espaços edificados vazios é encontrada em imóveis verticalizados, com um único proprietário para cada imóvel, sem desmembramento da propriedade, e com um período de desocupação superior a um ano.

A ocupação destes imóveis vagos através da reabilitação dos edifícios para população de baixa renda aparece como uma alternativa dentro de uma política habitacional mais ampla. Estas intervenções são complexas e diversos fatores ainda impossibilitam sua execução, como o alto preço dos imóveis, a falta de legislação e instrumentos urbanísticos adequados, falta de mão-de-obra capacitada, entre outros (REABILITA, 2007).

Nas últimas décadas, as administrações municipais não conseguiram formar uma política habitacional para a cidade capaz de suprir as deficiências do município. De acordo com Cymbalista (2007), "talvez mais do que qualquer outro município, São Paulo reflete a fragmentação e as dificuldades de realizar uma descrição global das ações relacionadas à política habitacional no Brasil. Justapõem-se desde investimentos de caráter municipal, estadual e federal, projetos com financiamento internacional, até investimentos relacionados ao saneamento básico com forte componente de habitação".

\footnotetext{
${ }^{5}$ Porém, deve-se ressaltar que existe uma impossibilidade de conhecer mais sobre a verdadeira situação desses imóveis, em relação às causas de estarem vazios e suas condições físicas, devido aos instrumentos disponíveis e utilizados para os levantamentos.
} 
A política habitacional deve promover condições de acesso à moradia digna a todos os segmentos da população, especialmente o de baixa renda, contribuindo, assim, para a inclusão social. Moradia digna que deve ser entendida como direito e vetor de inclusão social, garantindo padrão mínimo de habitabilidade, infra-estrutura, saneamento ambiental, mobilidade, transporte coletivo, equipamentos, serviços urbanos e sociais (CYMBALISTA, 2007).

Para que esta política realmente funcione, não basta que o Estado entregue para esta faixa da população uma casa ou apartamento em um conjunto habitacional. A população que necessita do parque habitacional público corresponde a grupos sociais com carências econômicas e problemas de inserção social e urbana. Trata-se de famílias cujas características sócio-demográficas e de história de vida conduzem a situações de pobreza crônica, dificuldade de inserção na vida urbana e, muitas vezes, em uma vida comunitária de bairro e relações de vizinhança (COELHO, 1999).

A ausência do Estado na gestão destes edifícios habitacionais após a ocupação pode vir a aumentar situações de segregação urbana e social, suscetíveis a cenários convidativos a situações de exclusão social (COELHO, 1999).

Até 1988, talvez pela própria carência de uma política nacional orientadora e financiadora comprometida, a cidade de São Paulo não teve uma política habitacional propriamente dita. Como Barreto Silva (1997) ressalta, cada administração corresponde a um discurso, um elenco de programas e um arranjo institucional diferente. Mais do que isso, a alternância política permite a sucessão de políticas contraditórias, anulando os efeitos das anteriores.

Na gestão 1989-1992, o Partido dos Trabalhadores venceu e São Paulo passou a ter a primeira gestão de um partido de esquerda comprometido com os movimentos populares da habitação. De acordo com Anjos (2004), uma das prioridades desta administração era a habitação popular, gestão que se destacou pela provisão de novas unidades, executadas através de empreiteiras ou por mutirão, e pelo programa de urbanização de favelas.

Com relação à reabilitação da área central, no início dos anos 90 a prefeitura desenvolveu alguns projetos e iniciativas que ainda não eram relacionados à habitação, mas à conservação dos edifícios culturais e importantes da cidade. Vários edifícios públicos do início do século foram restaurados, como o Teatro Municipal, a 
Biblioteca Mário de Andrade, o Palácio das Indústrias, entre outros (BARRETO SILVA, 2000). Outro fato marcante foi a volta da sede da prefeitura para o centro, com o intuito de facilitar o acesso aos serviços públicos pela população mais pobre através de transporte coletivo.

Em 1991, conforme analisa Barreto Silva (2000), várias entidades privadas, sobretudo bancos, decidiram fundar a Associação Viva o Centro, que se propunha a ser um interlocutor da sociedade civil com o poder público e desenvolver iniciativas para reabilitação do centro.

A partir de 1993, com a gestão Paulo Maluf, houve uma mudança radical na posição do município no que se refere à questão habitacional do centro. Criou-se uma comissão especial para coordenar as ações no centro (Procentro), que dava ênfase ao estímulo das atividades imobiliárias e às propostas tendentes a solucionar os problemas de acessibilidade do automóvel detectados como entrave ao desenvolvimento (BARRETO SILVA, 2000).

A maior parte dos programas habitacionais em andamento foram interrompidos devido à mudança do enfoque da gestão. Basicamente, o único programa habitacional criado durante a administração foi o Programa Cingapura, que tratava de construir, no mesmo local onde havia favelas, edifícios com apartamentos de $42 \mathrm{~m}^{2}$ em condições legais para abrigar famílias de até seis pessoas. Apesar de as metas do programa preverem a construção de 30 mil unidades, somente um terço disso foi executado. Nota-se, também, que algumas áreas foram atendidas parcialmente, ou seja, permaneceram trechos da favela junto aos conjuntos (ANJOS, 2004).

De 1997-2000, a administração Celso Pitta deu continuidade aos programas da gestão anterior, mas priorizou as obras do Programa de Saneamento Ambiental da Bacia do Guarapiranga em conjunto com o governo do Estado de São Paulo e o Banco Mundial (ANJOS, 2004).

Em 2001, o Partido dos Trabalhadores voltou ao poder com a gestão Marta Suplicy (2001-2004). A nova administração petista possuía em seu escopo programas que buscavam atingir mais amplamente a população necessitada com renda mensal de até três salários mínimos. Entre eles, destacam-se os programas Morar no Centro, Bairro Legal e Mutirões. 
O programa Morar no Centro foi formulado e colocado em prática no contexto de uma proposta mais abrangente do governo municipal de reabilitação da região central inserido no programa Ação Centro ${ }^{6}$. Tinha como objetivos melhorar as condições de vida dos moradores do centro, viabilizar moradia adequada para pessoas que habitam ou trabalham na região, e evitar o processo de expulsão da população mais pobre, o que muitas vezes ocorre em políticas de reabilitação de centros urbanos (PMSP, 2004).

Entre suas diretrizes estavam a reforma de prédios vazios, a combinação de soluções habitacionais com iniciativas de geração de renda e a busca pela diversidade social nos bairros centrais (PMSP, 2004). A bandeira da habitação popular nas áreas centrais é uma das principais reivindicações dos movimentos de luta por moradia na cidade, assim como de uma série de organizações ligadas à reforma urbana.

Entre os diversos sub-programas desenvolvidos, no âmbito do programa Morar no Centro, foram atendidas (com unidades habitacionais) 2.800 famílias, tendo sido produzidas aproximadamente 6.200 unidades habitacionais até o final de 2004 (ANJOS, 2004).

Para sua viabilização, foram desenvolvidas as seguintes modalidades de atendimento: o $\mathrm{PAR}^{7}$, nesse caso PAR/ Reforma, em que se financia a compra e a reabilitação de imóveis destinados à produção de habitações para população de baixa renda; o Programa de Locação Social, que contempla a produção de unidades habitacionais novas ou a compra e reforma de edifícios para alugar a famílias de baixa renda por valores subsidiados, compatíveis com seus rendimentos; e o Programa Bolsa Aluguel, que concede subsídios a famílias em áreas de risco ou insalubridade para que busquem novas alternativas (ANJOS, 2004).

\footnotetext{
${ }^{6}$ O Ação Centro é um programa da Prefeitura do Município de São Paulo coordenado pela Empresa Municipal de Urbanização (EMURB). O objetivo é reverter o processo de degradação e abandono do centro da cidade por meio da implementação de projetos sociais e intervenções urbanas capazes de requalificar os espaços públicos e restabelecer suas potencialidades. São objetivos do programa: a recuperação de áreas degradadas, a melhoria da qualidade ambiental, o fomento à pluralidade econômica, a inclusão social e o repovoamento residencial (PMSP, 2004).

${ }^{7}$ O PAR consiste em uma operação de aquisição de empreendimentos novos a serem construídos, em construção ou, a recuperar/ reformar. As unidades habitacionais dos empreendimentos adquiridos destinam-se à oferta de moradias, sob a forma de arrendamento residencial com opção de compra, às pessoas físicas enquadradas no Programa (BRASIL, MINISTÉRIO DAS CIDADES, 2005).
} 
Merecem destaque na gestão 2000-2004 os Perímetros de Reabilitação Integrada do Habitat (PRIH). Os Perímetros integraram a Política Habitacional para a Área Central da gestão no âmbito do Programa Morar no Centro e surgiram como uma tentativa de construção de uma nova forma de intervenção e gestão urbana de áreas centrais, com o objetivo de melhorar a qualidade de vida dos moradores, trabalhadores e usuários, por meio de ações integradas (PADOVANI, 2005).

Essa experiência se baseia na instalação de escritórios locais, denominados Escritórios Antena, dentro dos perímetros previamente delimitados, com o objetivo de aproximar o poder público da comunidade e dos problemas locais, por meio da instauração do processo de gestão e planejamento no local (VITALE, 2005).

Com a aprovação do Estatuto da cidade em julho de 2001, a cidade de São Paulo iniciou a elaboração de seu Plano Diretor Estratégico (Lei 13.430/02), instrumento previsto no Estatuto, que tem como objetivo descrever as diretrizes específicas de cada município na regulamentação, indução e controle da produção da cidade (Estatuto da Cidade, 2001).

Pela primeira vez na cidade de São Paulo, buscou-se incorporar às decisões políticas a participação efetiva da população (VITALE, 2005). Esta abertura, apesar de ainda ser considerada restrita, foi de grande importância para a tentativa de regulamentação, no corpo do Plano Diretor, dos instrumentos da Reforma Urbana propostos pelo Estatuto da Cidade, que exigem da propriedade fundiária o cumprimento de sua função social através de: parcelamento, edificação ou utilização compulsórios do solo urbano não edificado, Imposto Predial Territorial Urbano (IPTU) progressivo no tempo, usucapião especial de imóvel urbano, direito de superfície, direito de preempção, outorga onerosa do direito de construir, operações urbanas consorciadas e transferência do direito de construir. Nesses espaços, a Zona Especial de Interesse Social (ZEIS) foi a grande pauta defendida pelos movimentos sociais, organizações não-governamentais e entidades acadêmicas (VITALE, 2005).

As ZEIS são porções de território destinadas prioritariamente à recuperação urbanística, regularização fundiária, produção de Habitação de Interesse Social (HIS) e Habitação de Mercado Popular (HMP), incluindo a recuperação de imóveis degradados e provisão de equipamentos sociais e culturais ${ }^{8}$. A HIS se destina a

\footnotetext{
${ }^{8}$ As ZEIS são subdivididas em:

ZEIS 1- favelas, loteamentos precários e empreendimentos habitacionais de interesse social.

ZEIS 2- glebas e terrenos não utilizados ou subutilizados.(continua)
} 
famílias com renda igual ou inferior a seis salários mínimos, de promoção pública ou a ela vinculada, com padrão de unidade habitacional com um sanitário, até uma vaga de garagem e área útil de no máximo $50 \mathrm{~m}^{2}$; Já a HMP é aquela que se destina a famílias de renda igual ou inferior a 16 salários mínimos ou capacidade de pagamento a ser definida em lei específica, de promoção privada, com padrão de unidade habitacional com até dois sanitários, até uma vaga de garagem e área útil de no máximo $70 \mathrm{~m}^{2}$ (CYMBALISTA, 2007).

Na gestão de 2005-2008, dois partidos estiveram à frente da Prefeitura: o Partido da Social Democracia Brasileira (PSDB), de José Serra, e o Partido da Frente Liberal (PFL) / Partido Democratas (DEM), de Gilberto Kassab, que assumiu o mandato quando o então prefeito José Serra afastou-se do cargo para concorrer ao governo do Estado. Pela primeira vez em São Paulo, durante o período em que José Serra esteve à frente da prefeitura, o governador do Estado e o prefeito pertenciam ao mesmo partido político, o que favoreceu a construção de ações da Prefeitura em conjunto com o Governo do Estado, o que não ocorreu com a mesma intensidade em outros mandatos.

A gestão atual de Gilberto Kassab, que se reelegeu em 2009, não prioriza a política que promove a moradia no centro e aposta cada vez menos em financiamentos e instrumentos urbanísticos que favoreçam a habitação nesta área ${ }^{9}$.

O foco da atual gestão está em investimentos em urbanização de favelas e ocupações por toda a cidade, inclusive em mananciais. Este tipo de reurbanização proposta visa levar saneamento e reformas urbanas pontuais sem promover maiores interferências espaciais, como aberturas de espaços públicos, quadras etc.

De acordo com Cymbalista (2007), ainda que não tenha paralisado as ações de viabilização de moradia popular no Centro (o programa e o nome foram

ZEIS 3- áreas com predominância de terrenos ou edifícios subutilizados situados em áreas dotadas de infra-estrutura, serviços urbanos e oferta de empregos.

ZEIS 4- glebas ou terrenos não edificados e adequados à urbanização localizados em áreas de proteção aos mananciais ou de proteção ambiental (Fonte: Plano Diretor da Cidade de São Paulo)

${ }^{9}$ Do ponto de vista orçamentário, verificou-se uma redução da dotação da SEHAB (incluindo a dotação do Fundo Municipal de Habitação) para a região central: em 2004, foram gastos cerca de 46 milhões de reais na região (de 85 milhões orçados); em 2005, os gastos diminuíram para 25 milhões de reais (de 62 milhões orçados) e em 2006, foram orçados 40 milhões de reais e desembolsados apenas 9 milhões. Tal redução orçamentária significou, na prática, descontinuidades e redirecionamentos das ações e projetos em curso nas áreas centrais da cidade. Alterou-se significativamente a proporção de recursos orçamentários destinados às diferentes áreas da cidade (CYMBALISTA, 2007). 
mantidos), a gestão Serra, agora de Gilberto Kassab, enfatiza as dificuldades de manutenção de população de baixa renda no centro da cidade. A Superintendência de Habitação Popular (HABI) entende que para a faixa de renda de zero a três salários mínimos a intervenção adequada para realmente enfrentar a escala do déficit habitacional é a urbanização de favelas.

O projeto desta gestão para o centro da cidade é o projeto Nova Luz, que tem como objetivo principal uma renovação urbana de parte do bairro da Luz, conhecido como "cracolândia". O projeto propõe a demolição/ desapropriação dos imóveis deteriorados e a criação de novos espaços e empreendimentos com opções de moradia e novos equipamentos públicos (PMSP, 2007).

Em nenhuma das gestões apresentadas acima a questão da sustentabilidade social e econômica englobando a gestão pós-ocupação em edifícios voltados para HIS teve destaque. Alguns programas oferecem aos moradores um Trabalho Técnico Social (TTS) durante o período de mudança e implantação do condomínio.

O TTS tem como principal objetivo introduzir na vida em condomínio esta população proveniente principalmente de coabitações e favelas, ressaltando seus direitos e obrigações. Informa, ainda, dados sobre o programa habitacional do qual fazem parte, esclarecem o papel dos moradores e do órgão promotor, entre outros pontos, como os aspectos de convivência e conservação do imóvel. Neste trabalho, geralmente, os técnicos sociais fazem plantões semanais no edifício tirando dúvidas e auxiliando os moradores em questões diversas. Em alguns casos, propõem oficinas e eventos dentro do prédio com o objetivo de aproximar os moradores (CEF, 2008).

Entretanto, o trabalho social existente demonstra ser, na maioria dos casos, somente um "acompanhamento social". A concepção de trabalho social como conjunto de ações inclusivas com caráter socioeducativo não existe nos edifícios voltados para HIS.

A chamada gestão condominial não deve incluir somente a instalação do condomínio e trabalhos pontuais feitos pelos técnicos. A gestão destes edifícios após a entrada dos moradores, objeto de estudo deste trabalho, deve significar algo mais amplo e duradouro em que o poder público deve assumir um papel de mediador e estar sempre presente. 
Os conflitos encontrados em conjuntos habitacionais para população de baixa renda são, antes de tudo, sociais e sócio-urbanísticos, pois tratam de pessoas que geralmente possuem acentuados problemas de inserção social e urbana. São também problemas econômico-financeiros, pois a premissa básica para ser parte deste grupo é estar em uma faixa de renda de no máximo seis salários mínimos, ou seja, são grupos sociais com carências econômicas. Problemas técnico-construtivos também estão presentes devido ao baixo investimento na construção, o que acaba refletindo na baixa qualidade da edificação e resulta em diversas implicações econômicas para os moradores causadas pelos custos com manutenção.

Enfim, após este panorama sobre a política habitacional nacional e da cidade de São Paulo, em que o momento da necessidade dos programas envolvendo a reabilitação dos edifícios nos centros voltados para HIS é abordado, serão apresentados a seguir os agentes e processos relacionados à reabilitação de edifícios na cidade.

\subsection{O procedimento para reabilitação de edifícios em São Paulo}

$\mathrm{Na}$ cidade de São Paulo, os primeiros projetos de reabilitação de edifícios vazios para HIS foram viabilizados por meio de uma parceria entre a Prefeitura da Cidade de São Paulo (PMSP) e o governo federal, através do Programa de Arrendamento Residencial (PAR), operacionalizado pela Caixa Econômica Federal (CEF) e financiado pelo Fundo de Arrendamento Residencial (FAR).

De acordo com a Lei $n^{\circ} 10.188$ de 12/02/2001, que cria o programa, o PAR consiste em uma operação de aquisição de empreendimentos novos, a serem construídos, em construção ou a recuperar/ reformar. As unidades habitacionais dos empreendimentos adquiridos destinam-se à oferta de moradias para famílias com renda mensal entre três e seis salários mínimos, sob a forma de arrendamento residencial (MALERONKA, 2005).

De acordo com Menezes (2008), o arrendante é o operador do arrendamento, o qual adquire a propriedade do bem e entrega a posse direta do mesmo para o arrendatário. $\mathrm{O}$ arrendatário é a pessoa que, por meio do contrato de arrendamento, adquire a posse direta do bem por prazo determinado. 
Com o contrato de arrendamento residencial, os arrendatários podem arrendar unidades residenciais com prestações mensais equivalentes a um aluguel, cabendo aos mesmos a opção de adquirir o bem arrendado com o pagamento do valor residual após 15 anos. Tal modalidade de financiamento veio para proporcionar às famílias de baixa renda a oportunidade de adquirir a casa própria sem terem de arcar, desde o início, com o pagamento da integralidade de seu preço (MENEZES, 2008).

\section{Segundo Menezes (2008):}

"Constitui obrigação do arrendante entregar o bem em condições de ser utilizado para a finalidade a que se destina (moradia), garantir a posse mansa e pacífica do bem pelo arrendatário enquanto durar o contrato de arrendamento e, ao final do mesmo, submeter-se à decisão do arrendatário de aquisição da propriedade do bem. São obrigações do arrendatário ${ }^{10}$ pagar mensalmente a taxa de arrendamento e demais despesas incidentes sobre o imóvel (ex. IPTU, energia elétrica, água, taxas de condomínio etc.); conservar a integridade do bem, mantendo-o em perfeitas condições de habitabilidade; utilizar o imóvel com finalidade residencial e observar as demais cláusulas do contrato de arrendamento" (MENEZES, 2008).

Além dos arrendatários e do arrendante, o programa possui diversos agentes envolvidos no processo, desde a concepção do projeto até a entrada dos moradores, conforme tabela a seguir (Tabela 2.1):

\footnotetext{
${ }^{10}$ Item n ${ }^{\circ} 2.5 .4$ da Portaria $n^{\circ}$ 301/2006, com redação dada pela Portaria $n^{\circ} 440 / 2006$, ambas do Ministério das Cidades.
} 
Tabela 2.1 Agentes envolvidos no Programa de Arrendamento Residencial (PAR)

\begin{tabular}{|c|c|}
\hline Agente & Ações \\
\hline Ministério das cidades & $\begin{array}{l}\text { Agente gestor do PAR, a quem compete estabelecer diretrizes, fixar regras e } \\
\text { condições para implementação do Programa, alocar os recursos entre as } \\
\text { Unidades da Federação, além de acompanhar e avaliar o desempenho do } \\
\text { programa. }\end{array}$ \\
\hline Caixa Econômica Federal & $\begin{array}{l}\text { Agente executor do PAR, responsável pela alocação dos recursos, definição } \\
\text { dos critérios e expedição dos atos necessários à operacionalização do } \\
\text { programa. }\end{array}$ \\
\hline Ministério da Fazenda & $\begin{array}{l}\text { Em conjunto com o Ministério das Cidades, fixa a remuneração da CEF, pelas } \\
\text { atividades exercidas no âmbito do programa. }\end{array}$ \\
\hline $\begin{array}{l}\text { Poder Público Estadual e } \\
\text { Municipal }\end{array}$ & $\begin{array}{l}\text { Tem sua participação estabelecida por meio de assinatura de convênio com a } \\
\text { CEF, visando assegurar a sua colaboração nas ações em prol do } \\
\text { desenvolvimento de fatores facilitadores à implementação dos projetos, } \\
\text { destacando-se a indicação das áreas priorizadas para implantação dos } \\
\text { projetos, isenção de tributos e indicação de demanda para os } \\
\text { empreendimentos. }\end{array}$ \\
\hline Construtoras & $\begin{array}{l}\text { Participam na apresentação de propostas e execução dos projetos aprovados } \\
\text { para aquisição de unidades habitacionais na forma estabelecida pelas normas } \\
\text { do programa. }\end{array}$ \\
\hline Arrendatário & $\begin{array}{l}\text { Pessoa física que, atendidos os requisitos estabelecidos para o programa, seja } \\
\text { habilitada ao arrendamento de imóvel do PAR; }\end{array}$ \\
\hline $\begin{array}{l}\text { Empresas do ramo da } \\
\text { Administração Imobiliária }\end{array}$ & $\begin{array}{l}\text { Empresas contratadas para administrar os contratos de arrendamento, os } \\
\text { imóveis e condomínios. }\end{array}$ \\
\hline $\begin{array}{l}\text { Executor do Trabalho Técnico } \\
\text { Social }\end{array}$ & $\begin{array}{l}\text { Pessoa jurídica, selecionada por meio de credenciamento, para elaborar e } \\
\text { executar o programa de trabalho técnico social nos empreendimentos } \\
\text { contratados. }\end{array}$ \\
\hline
\end{tabular}

Fonte: CEF, 2008.

Além dos agentes apresentados no quadro acima, devemos destacar também a importante participação dos movimentos sociais de luta por moradia e das assessorias técnicas no processo de reabilitação de edifícios em São Paulo. A atuação destes agentes engloba desde a indicação das edificações vazias para os agentes públicos responsáveis pelos programas, até a indicação da demanda ou parte dela.

Após a entrega das unidades, o contato dos moradores com a construtora, com o poder público estadual ou municipal, e com a própria CEF é bastante reduzido, ficando a cargo da administradora de condomínios realizar. A administradora, escolhida por licitação, passa a ser o síndico do prédio (direito transferido pela $(E F)$, além de fazer a gestão condominial do mesmo. O contrato entre a CEF e a administradora é de cinco anos, podendo ser renovado. 
A administradora realiza reuniões com os mutuários para serem definidos os custos e melhorias no imóvel durante o ano, além de operacionalizar toda a parte burocrática dos condomínios. A partir do valor final encontrado é que se define o valor da taxa condominial, acrescido da remuneração da administradora (REABILITA, 2007).

Já o Trabalho Técnico Social (TTS) é iniciado no momento da mudança dos arrendatários e tem duração máxima de seis meses. De acordo com os técnicos sociais da CEF, quando o contrato com a construtora é assinado, $1 \%$ do valor total do empreendimento é destinado à realização do trabalho social. Deste $1 \%$, somente $80 \%$ é utilizado no trabalho, pois $20 \%$ fica como uma reserva para qualquer tipo de problema ou necessidade de intervenção futura (informação verbal) ${ }^{11}$.

O objetivo principal do TTS é informar às famílias moradoras o que é o programa de arrendamento, as diferenças em relação aos programas de aquisição de imóveis, o papel da CEF, das administradoras, dos moradores, entre outros ponrtos, como aspectos de convivência e conservação do imóvel ${ }^{12}$.

Neste trabalho, os técnicos sociais fazem plantões semanais no edifício tirando dúvidas e auxiliando os moradores em questões diversas. Em alguns casos, propõem oficinas e eventos dentro do prédio com o objetivo de aproximar os moradores.

Porém, a maioria dos moradores faz parte de algum movimento social de luta por moradia, e possui uma ou várias lideranças que têm como objetivo, promover a união deste grupo. "Com isso, a população, quando muda para o prédio, já é um grupo formado, as pessoas se conhecem e se respeitam e de certa forma acabam obedecendo aos líderes. Estes líderes são vistos como grandes chefes que conseguiram aquilo para eles de uma forma ou de outra". ${ }^{13}$

Entretanto, este grupo formado, na maioria das vezes, é um grupo que não permite interferências, o que muitas vezes acaba interferindo no trabalho. A chegada dos técnicos sociais, algumas vezes, traz uma sensação de ameaça aos líderes, que não permitem que o trabalho social seja feito: "É muito complicado entrar para fazer um trabalho com esta população. Eles já são muito organizados e não estão abertos

\footnotetext{
${ }^{11}$ Informação fornecida pela técnica social Célia Teixeira em entrevista realizada em 22 de junho 2007.

${ }_{12}$ Idem, 2007.

${ }^{13}$ Idem, 2007.
} 
a mudanças. As lideranças têm medo e este medo é passado para os moradores, que acabam sabotando o trabalho". ${ }^{14}$

O fluxo apresentado a seguir (Figura 2.1) procura ilustrar as fases do processo de arrendamento residencial no PAR indicando as interfaces entre os agentes.

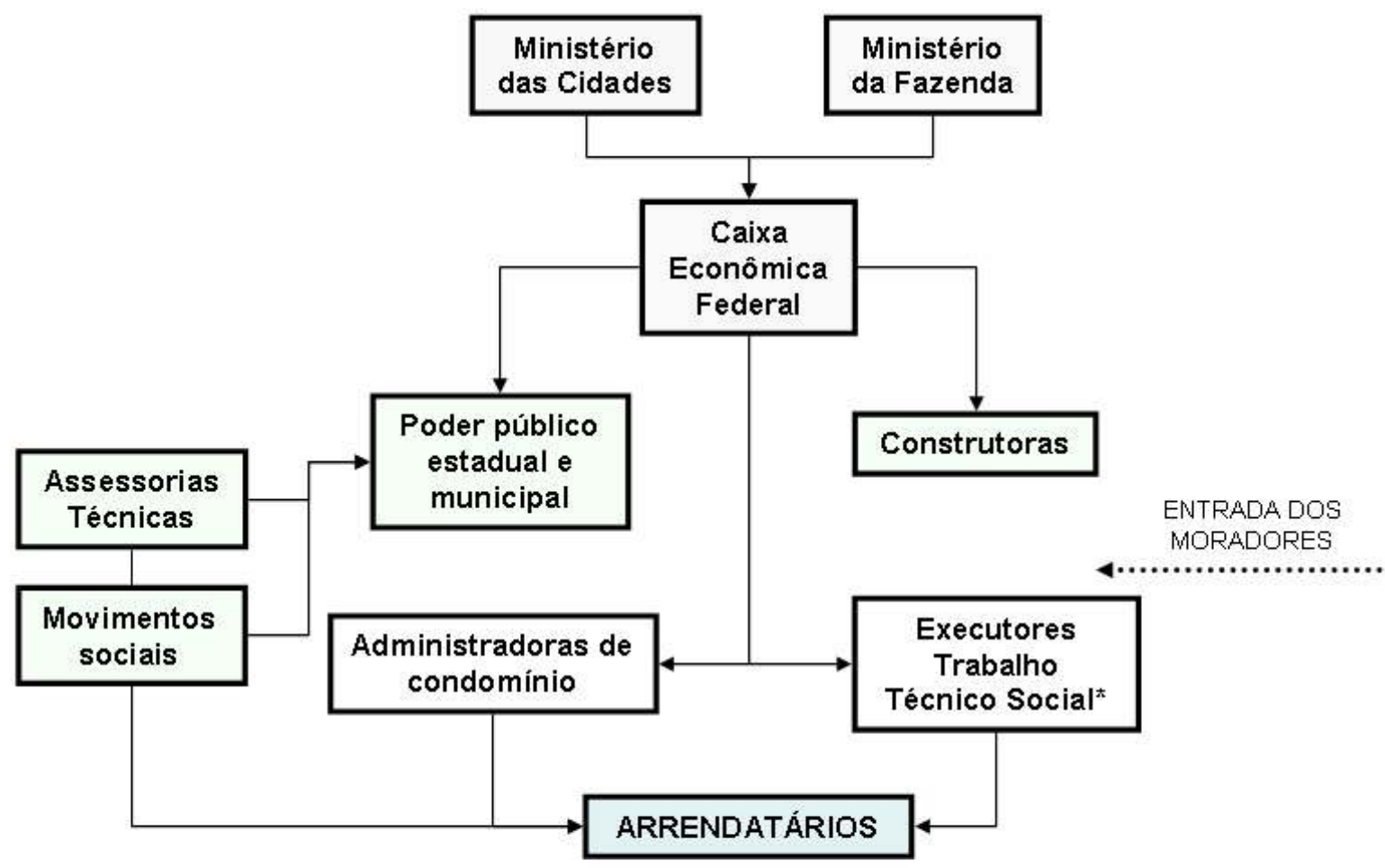

*Até 6 meses após a

entrada no edifício

Figura 2.1 Fluxo ilustrativo representando as interfaces entre os agentes dentro do Programa de Arrendamento Residencial.

Fica claro que, após a entrada dos moradores, os únicos canais de comunicação que existem entre os arrendatários e o órgão promotor são as empresas administradoras e as empresas executoras do trabalho social. Entretanto, cabe ressaltar que após os seis meses estipulados para a realização do TTS, o trabalho é encerrado, restando no edifício somente as administradoras, que fazem o papel de gestoras e de síndicas do condomínio.

\footnotetext{
${ }^{14}$ Informação fornecida pela técnica social Célia Teixeira em entrevista realizada em 22 de junho 2007.
} 


\section{Gestão pós-ocupação em edifícios verticalizados}

O período da pós-ocupação em edifícios ocorre após a entrada dos usuários na edificação. A gestão deste período pode englobar desde complexas relações sociais entre moradores e visitantes até problemas técnico-administrativos relacionados ao edifício.

De acordo com Motta (1995), no rigor vernacular, as palavras administração, gerência e gestão são sinônimas ${ }^{15}$. No sentido conceitual, nada foi introduzido quando se procurou acentuar o uso de uma palavra em detrimento da outra, salvo, evidentemente, o adquirido desgaste de uma para recuperar conceitos anteriores por meio de um novo termo (MOTTA, 1995).

O conceito clássico de administração ou gestão estabelecido por Fayol (1916) envolve quatro grandes funções administrativas: planejar, organizar, dirigir e controlar. A fase do planejamento deve estabelecer os objetivos a serem alcançados e desenvolver um plano de ações para atingir as metas traçadas; a organização deve coordenar todos os recursos, sejam humanos, financeiros ou materiais, alocando-os da melhor forma segundo o planejamento estabelecido. Já a direção deve coordenar as atitudes e esforços de todos, almejando as metas traçadas e, por fim, o controle, que deve estabelecer padrões e medidas de desempenho que permitam assegurar que as atitudes empregadas sejam as mais compatíveis com o que se espera (CHIAVENATO, 1999).

Drucker (1965) sustenta que administração nada mais é do que o processo de tomada de decisão e o controle sobre as ações dos indivíduos para o expresso propósito de alcance de metas pré-determinadas.

Megginson et al. (1998) afirmam que a administração foi definida como o uso de recursos humanos, financeiros e materiais para atingir objetivos da organização por meio das funções de planejamento, organização, liderança e controle.

Silva (2004) apud Carneiro (2004) enfatiza que a administração é um conjunto de atividades dirigidas à utilização eficiente e eficaz dos recursos, no sentido de alcançar um ou mais objetivos ou metas organizacionais.

\footnotetext{
${ }^{15}$ A palavra administração, antes aceita em português para expressar um novo campo de conhecimento e uma nova prática profissional, parou de ser utilizada, sendo substituída pela expressão "gerência". Na última década, a palavra gestão ganhou força e passou a ser utilizada com bastante freqüência.
} 
Em perspectiva complementar, Araújo (2004) afirma que em muitos casos a quarta função administrativa estabelecida por Fayol pode garantir ou não o sucesso do processo, pois mesmo estando a organização devidamente planejada, organizada e liderada, é de extrema importância que haja um acompanhamento das atividades a fim de se garantir a execução do planejado e a correção de possíveis desvios.

Sendo assim, levando em consideração os diversos significados elencados, em particular o conceito proposto por Fayol (1916), no presente trabalho o termo gestão pós-ocupação será entendido como 0 controle das atividades e acontecimentos relacionados tanto ao edifício quanto a seus usuários, ocorridos no período de uso e operação do prédio para garantir a realização do objetivo inicial planejado para a edificação.

\subsection{Gestão pós-ocupação em edifícios verticalizados residenciais}

Os edifícios de habitação coletiva são compostos por unidades de habitação sobrepostas em que a propriedade do terreno, dos espaços livres e de acessos às unidades residenciais é comum aos diversos moradores, a partir de uma fração ideal da área para cada unidade (ZANDONADE, 2005).

De acordo com Lopes, J.B. (2006), o proprietário de um apartamento é titular de um direito de natureza complexa, exercendo seu direito de co-proprietário sobre as partes comuns e seu domínio sobre as partes exclusivas.

Sendo assim, o condomínio aparece como uma forma de regulamentação do exercício ou do uso desta propriedade (Lopes J.B, 2006).

A seguir serão apresentados os conceitos e métodos utilizados para a implementação de um condomínio em edifícios verticalizados no Brasil. 


\subsubsection{O condomínio em edifícios no Brasil}

A palavra condomínio assinala a circunstância de ser a propriedade pertencente a mais de uma pessoa, formada da preposição com e do substantivo domínio, do latim dominium (direito de propriedade). Na linguagem do Direito Civil, significa o direito simultaneamente tido por várias pessoas sobre o mesmo objeto. (SILVA, D. P., 1978).

De acordo com o dicionário MICHAELIS, condomínio pode ser definido como "domínio que pertence a duas ou mais pessoas juntamente". Outras definições também podem ser encontradas, tais como co-propriedade (LEME, 1995), ou propriedade com mais de um titular (CONTRERAS, 2001).

O condomínio pode existir em qualquer situação em que há um bem cujo domínio pertença a várias pessoas (físicas ou jurídicas) (PEREZ. 1985).

No Brasil, a primeira regulamentação direcionada aos condomínios foi o Decreto n. 5.481, de 25/06/1928, que procurou disciplinar a matéria de forma a expressar a diferença entre as partes comuns e as exclusivas (arts. $1 .^{\circ}$ e 2. ${ }^{\circ}$ ). $\mathrm{O}$ decreto dispôs sobre a administração do imóvel (art. 8. ${ }^{\circ}$ ) e a participação nas despesas (art. 9. ${ }^{\circ}$ ), prescrevendo ainda no artigo $11^{\circ}$ a proibição de alteração da forma externa da fachada (LOPES, J.B., 2006).

Em 16 de dezembro de 1964 foi promulgada a Lei n. 4.591, denominada Lei de Condomínio. A nova legislação determinou a sistemática da vida em condomínio nos seus aspectos formais e estabeleceu normas a serem seguidas na convenção, regimento interno, assembléias, cargo e eleição de síndicos e conselhos, entre outros (LEME, 1995).

A Lei de Condomínio, no entanto, necessitava de uma atualização para preencher lacunas decorrentes de novas situações surgidas nos condomínios atuais, além da necessidade de adaptação ao Código de Defesa do Consumidor (1990) (CONTRERAS, 2001).

O novo Código Civil $^{16}$, promulgado em janeiro de 2002, passou a regular integralmente o condomínio em edifícios, agora denominado condomínio edilício ${ }^{17}$. $\mathrm{O}$

\footnotetext{
${ }^{16}$ Lei n. $^{\circ} 10.406$ de 10/01/2002.

17 De acordo com o Professor Miguel Reale apud Lopes, 2006: “(...) Na realidade, é um condomínio que se constitui objetivamente, como resultado do ato de edificação, sendo, por tais motivos, denominado 'edilício'. Esta palavra vem de aedilici (um), que não se refere apenas ao edil, consoante que foi mencionado, mas, como ensina o mestre F. R. Santos Saraiva, também às suas atribuições,
} 
novo Código traz, nos artigos n. 1.331 a 1.358, disposições mais recentes sobre o tema, visando preencher lacunas existentes na antiga lei (CONTRERAS, 2001).

Dentre as alterações mais significativas, estão: a fixação do valor da multa cobrada por atraso, que passa a ser de, no máximo, $2 \%$ sobre o débito, enquanto que na legislação anterior era de 20\%; o fim da obrigatoriedade do Fundo de Reserva, o qual era destinado a cobrir despesas extraordinárias ou imprevistas que fogem ao conceito normal de administração; o rateio de despesas com base na proporção das frações ideais entendidas como a parte do terreno que proporcionalmente cabe a cada condômino; e os critérios para convocação de assembléias $^{18}$.

O condomínio não é considerado pessoa jurídica, não conta com renda mensal ou anual e não declara Imposto de Renda. Mas, na prática, age como pessoa jurídica, pois compra, vende, contrata funcionários, presta serviços etc. Por isso, os condomínios devem ter uma denominação legal e inscrever-se no Cadastro Nacional de Pessoas Jurídicas (CNPJ) ${ }^{19}$.

No edifício, existem partes de uso comum e partes de uso exclusivo das unidades. São considerados comuns os elementos destinados ao serviço do prédio e de seus usuários: o solo, as escadas, os pátios, os elevadores, a portaria, a fachada, o hall social, salão de festas, garagens, piscina, etc. As áreas de uso exclusivo (áreas privativas) são constituídas pelas unidades autônomas e possuem identificação própria.

De acordo com Contreras (2001), todos os condôminos ${ }^{20}$ têm direito ao uso das áreas comuns e a obrigação de mantê-las. O uso da unidade autônoma, embora privativo, também está sujeito às limitações representadas pelos direitos dos demais condôminos.

Os condomínios edilícios possuem, de acordo com o Código Civil, uma norma interna que visa regulamentar a vida do edifício com o intuito de resolver seus

dentre as quais sobreleva a de fiscalizar as construções públicas e particulares" (Exposição de Motivos ao Projeto).

${ }^{18}$ Estes pontos serão melhor explicados adiante.

${ }^{19}$ O Código Civil utiliza a expressão "condomínio edilício" para qualquer edificação ou conjunto de edificações, mesmo que térreas, com unidades comuns e autônomas (CONTRERAS, 2001).

${ }^{20}$ Condôminos são os proprietários das unidades do condomínio, mesmo que não as habitem. 0 dono de uma unidade locada não deixa de ser condômino (LEME/ 1996). 
problemas, que envolvem não apenas os condôminos, como também terceiros. É a chamada Convenção de Condomínio, que, já por exigência da Lei 4.591/64, é documento indispensável.

A Convenção, que deve ser subscrita por no mínimo $2 / 3$ da fração ideal ${ }^{21}$, discrimina os direitos e deveres dos condôminos. Contêm as normas de utilização do condomínio, tanto relativas às partes comuns quanto às partes privativas, com o fim de resguardar, em proveito de todos, o patrimônio condominial ${ }^{22}$ (LOPES, J.B., 2006).

O Novo Código Civil exige que a Convenção determine:

"I - discriminação e individualização das unidades autônomas e das partes comuns;

II - determinação da fração ideal atribuída a cada unidade, relativamente ao terreno e partes comuns;

III - o fim a que as unidades se destinam;

IV - a quota proporcional e o modo de pagamento das contribuições dos condôminos para atender às despesas do condomínio;

V - a forma de administração do condomínio;

VI - a competência das assembléias, a forma de sua convocação e quorum exigido para as deliberações;

VII - as sanções a que estão sujeitos os condôminos;

VIII - o Regimento Interno"23.

Segundo o art. 1351 do Código Civil, "a Convenção deve ser registrada em Cartório de Registro de Imóveis e qualquer alteração só será possível por meio de assembléia convocada especialmente para este fim e requer o mesmo quorum

\footnotetext{
${ }^{21}$ Entende-se por fração ideal a parte do terreno que proporcionalmente cabe a cada condômino. A fração ideal é calculada no momento da instituição do condomínio, podendo para tanto sererm adotados dois critérios distintos: o valor das unidades na época da instituição do condomínio ou a área do apartamento em relação ao total do imóvel (CONTRERAS, 2001).

${ }^{22}$ Nesse sentido, observa José Roberto Neves Amorim, in Lopes, 2006: "Daí podemos dizer que convenção condominial é o conjunto de normas criadas e impostas pelos próprios condôminos, regulamentadoras do comportamento e da conduta das pessoas que vivem numa comunidade determinada ou que nela estejam, ainda que temporariamente, sujeitando-se às sanções em caso de violação, mas sempre de acordo com as leis emanadas do poder público".
}

${ }^{23}$ A Convenção pode incluir outras disposições de interesse do condomínio, desde que não conflitem com a legislação. 
exigido para a aprovação do documento original" (art. 1.351 do Novo Código Civil, 2002).

A Convenção também relaciona as regras específicas de convivência para o condomínio. Este conjunto de regras é chamado de Regimento ou Regulamento Interno $^{24}$. Este não pode conflitar com a Convenção e caso isto ocorra esta deve prevalecer. Com o passar do tempo e surgimento de novas situações, o Regimento pode ser alterado dependendo apenas dos votos de $2 / 3$ dos condôminos (art. 1.351 do Novo Código Civil, 2002).

O novo Código Civil também prevê os direitos e deveres do condômino. "Todo condômino tem direito a: usar, fruir e livremente dispor das suas unidades; usar as partes comuns, conforme a sua destinação e contanto que não exclua a utilização dos demais condôminos; votar nas deliberações da assembléia, desde que não esteja inadimplente com as obrigações financeiras condominiais".

É dever dos condôminos, segundo o Novo Código Civil: contribuir para as despesas do condomínio, na proporção de suas frações ideais; não realizar obras que comprometam a segurança da edificação; não alterar a forma nem cor da fachada, das partes e esquadrias externas; dar às partes a mesma destinação que tem a edificação, e não as utilizar de maneira prejudicial ao sossego, salubridade e segurança dos condôminos ou aos bons costumes (Novo Código Civil, 2002).

De acordo com o novo Código Civil, uma Assembléia Geral Ordinária (AGO) deve ocorrer pelo menos uma vez por ano. A Assembléia é o órgão máximo para deliberação e tomada de decisões de um condomínio. Todas as decisões tomadas em assembléia devem ser seguidas como regras, desde que baseadas na Convenção de Condomínio, à qual não podem se sobrepor (CONTRERAS, 2001).

A finalidade principal da AGO é deliberar sobre o orçamento das despesas, as contribuições dos condôminos, a prestação de contas e eventualmente eleger o síndico $^{25}$, representante legal do condomínio, morador ou não, que exerce as

\footnotetext{
${ }^{24}$ O Regimento interno contém regras específicas de convivência, como a utilização de áreas comuns (piscina, salão de festas, garagem etc) e das áreas privativas (permanência de animais, horários para mudanças, horários das festas etc).

${ }^{25}$ A Assembléia poderá deliberar também sobre: assuntos de rotina administrativa; exame de propostas de obras; constituição de uma comissão especial para acompanhar obras; eleição do subsíndico e conselheiros; constituição de fundo de reserva; quaisquer outros assuntos de interesse do condomínio.
} 
funções administrativas. O síndico ${ }^{26}$ deve ser eleito na Assembléia Geral, podendo ser candidato para o cargo qualquer condômino ou outra pessoa, física ou jurídica, que irá exercer a gestão do condomínio. O mandato do síndico é de dois anos, mas a lei permite que ocorra reeleição por igual período.

O síndico profissional é uma pessoa que em geral não reside no prédio e é paga para exercer a função administrativa. Muitas vezes responde pela administração de vários prédios ao mesmo tempo, podendo cobrar seus serviços com base no número de apartamentos ou na arrecadação do prédio. A demanda por esta função tem crescido devido à falta de tempo, de interesse ou até capacidade dos moradores de se tornarem síndicos (SCHWARTZ, 2007).

O artigo 1.348 do novo Código Civil dispõe sobre as responsabilidades do síndico:

"I - convocar a assembléia dos condôminos

II - representar, ativa e passivamente, o condomínio, praticando, em juízo ou fora dele, os atos necessários à defesa dos interesses comuns;

III - dar imediato conhecimento à assembléia da existência de procedimento judicial ou administrativo, de interesse do condomínio;

IV - cumprir e fazer cumprir a convenção, o regimento interno e as determinações da assembléia;

V - diligenciar a conservação e a guarda das partes comuns e zelar pela prestação dos serviços que interessam aos possuidores ${ }^{27 "}(\mathrm{CC})$.

Além do síndico, o condomínio pode eleger em Assembléia um conselho fiscal que tem como objetivo dar um parecer sobre as contas do síndico. Este conselho normalmente é constituído por três condôminos e pode funcionar também como um órgão assessor na gestão do condomínio.

Cabe ao síndico, portanto, zelar pela boa harmonia do condomínio, porém, sempre fiscalizando o cumprimento do regimento interno, o comportamento dos condôminos e as normas relativas às despesas de condomínio.

\footnotetext{
${ }^{26}$ Segundo o Professor Francisco Menna Barreto Reis, "O perfil do síndico ideal pode ser buscado na antiga Grécia, cujo significado literal é: Syn = com + Diké = justiça. O síndico é uma figura eleita para administrar as relações humanas, jurídicas e materiais, com equidade e justiça, para que a convivência seja pacífica."

(http://aspcondominios.com.br/materias/comportamento/mat_03.asp - acessado em 19/09/2007)

${ }^{27}$ Como exemplo: A Assembléia Geral de um edifício pode definir que o salão de festas não pode ser transformado em palco de shows públicos ou que a piscina não pode ser utilizada por estranhos e que a sala de ginástica não pode converter-se em parque infantil. Ou seja, cada condomínio possui suas próprias regras de acordo com seus moradores.
} 
De acordo com o novo Código Civil, é dever do condômino contribuir para as despesas do condomínio na proporção das suas frações ideais.

Segundo Gabas apud Lopes, J.B. (2006), as despesas podem ser divididas em:

a) Despesas com administração: são as que se destinam a cobrir gastos com a conservação e funcionamento do edifício, inclusive reparações nas partes comuns para manter as condições normais de segurança, conforto etc;

b) Despesas com inovações: objetivam melhorar as condições de uso e gozo do prédio;

c) Fundo de Reserva: destinado a cobrir despesas extraordinárias ou imprevistas que refogem ao conceito normal de administração;

d) Despesas decorrentes de atos de condôminos: são efetuadas por um ou vários condôminos, na omissão do síndico, em casos especiais, como reparações urgentes no prédio. (LOPES, J.B., 2006).

O valor mensal pago pelos condôminos é referente às despesas com administração, citadas anteriormente. De acordo com Schwartz (2007), o gráfico a seguir (Gráfico 3.1) demonstra a composição das despesas existentes nas taxas:

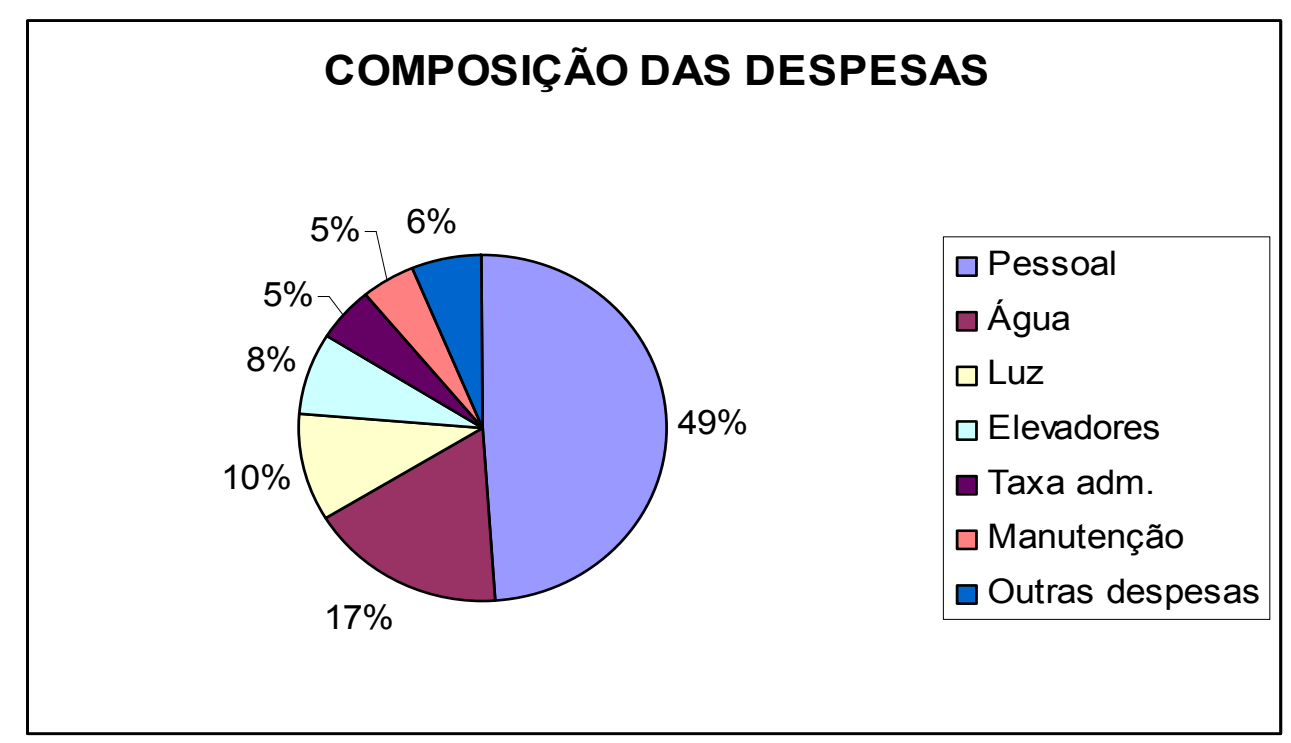

Gráfico 3.1 Composição das despesas em um condomínio. Fonte: SCHWARTZ, 2007. 
O condômino que não pagar contribuição ficará sujeito aos juros moratórios convencionados ou, não sendo previstos, aos juros de $1 \%$ ao mês e multa de até $2 \%$ sobre o débito ${ }^{28}$ (CONTRERAS, 2001).

Segundo Couto (2005), a inadimplência é extremamente prejudicial em um condomínio, já que, além de fazer com que uns paguem por outros, deteriora gradativamente o patrimônio, prejudicando a todos os condôminos indistintamente. Um edifício sem caixa não consegue primar pela valorização e conservação predial, isto é, não tem recursos para fazer os reparos necessários em razão do desgaste natural causado pela passagem do tempo.

Os prédios com alto índice de inadimplência não conseguem, por um lado, recursos para a conservação e manutenção predial e, por outro, apresentam quotas com valores inflacionados para cobrir dívidas existentes (COUTO, 2005).

A manutenção de um edifício pode ser definida como "uma série de operações empreendidas visando minimizar o ritmo de deterioração na vida de um edifício e desenvolvidas sobre as diversas partes e elementos da construção, assim como sobre as suas instalações e equipamentos. São operações programadas e geralmente efetuadas em ciclos regulares" (AGUIAR; CABRITA; APPLETON, 2002).

Para Bezerra (2000), a manutenção das edificações envolve conhecimentos técnicos e procedimentos administrativos com a finalidade de conservar as características de segurança, funcionalidade, confiabilidade, higiene e o mesmo padrão de conforto de quando o imóvel foi entregue para uso.

De acordo com a Norma Brasileira - NBR 5674 Manutenção de edificações: "a manutenção justifica-se por ser ato ou efeito de resguardar de danos, decadência, prejuízo e outros riscos, mediante verificação atenta do uso e condições de permanência das características técnicas e funcionais da edificação e das suas instalações e equipamentos".

Estas características citadas na referida norma são assim descritas:

> Características funcionais: são as que envolvem a manutenção das peculiaridades técnicas dos espaços privados e comuns, das instalações e

\footnotetext{
${ }^{28}$ Existem duas sanções distintas a serem aplicadas sobre o débito: juros moratórios e multa. Os juros moratórios devem ser aplicados a cada mês em que perdurar a dívida, sempre sobre o débito inicial. A multa, no entanto, deve ser aplicada apenas uma única vez também sobre o débito inicial (CONTRERAS, 2001).
} 
equipamentos, de modo que estejam disponíveis pelo máximo de tempo, com baixo custo e alta confiabilidade;

> Características de segurança: são concernentes à manutenção da segurança e estabilidade da estrutura, ao fogo, à chuva, e às demais intempéries que possam causar riscos à integridade física de usuários e terceiros;

> Características de higiene: dizem respeito à manutenção do asseio dos pisos, paredes, esquadrias, mobiliários, instalações e equipamentos de saneamento, em defesa da saúde dos usuários e terceiros;

> Características de conforto: voltam a atenção para a manutenção da comodidade e bem-estar dos usuários proporcionados por dispositivos construtivos, como isolamento térmico, acústico, ventilação, refrigeração, aquecimento; e visuais, como pintura e jardins. (NBR 5674).

De acordo com Bezerra (2000), algumas destas características são mantidas por serviços operados de forma permanente e rotineira, enquanto outros são realizados periodicamente:

Serviço de manutenção geral - são os serviços relativos às áreas, instalações e equipamentos comuns que não exigem grande especialização técnica e que têm programação de curto prazo (diária, semanal e mensal), como: vigilância, limpeza, jardinagem, remoção de resíduos, distribuição de correspondência, entre outros. Devem ser desempenhados pelo pessoal efetivo, próprio ou locado no condomínio pela empresa administradora.

Serviços de manutenção específica - demanda serviços especializados e obras de engenharia e devem ser dirigidos por profissionais legalmente habilitados. São programados no médio e longo prazo. Entre outros, pode-se relacionar: inspeção e limpeza do telhado, tubulação, ralos, fossas, caixas de visita, poços, reservatórios de água (inferior e superior), defeitos e patologias estruturais, pinturas e revestimentos, impermeabilizações, esquadrias e vidros, instalações hidráulicas, sanitárias, elétricas, telefônicas, pára-raios, geradores, transformadores, elevadores, alarme, instalações e extintores de combate ao fogo, ventilação, refrigeração e aquecimento. 
Por ser uma atividade relativamente nova, a manutenção predial não atingiu o patamar em que se encontra a manutenção industrial. A manutenção das edificações foi por muito tempo pouco considerada, pois a ênfase era construir e não conservar as obras existentes. Hoje, o estoque de imóveis já atinge um número tal, que é relevante cuidar da conservação deste patrimônio.(Bezerra, 2000).

A manutenção predial deve ser uma intervenção constante, pois, de acordo com Rizzo (2006) "A manutenção, quando é preventiva - aquela que se faz para evitar que um problema surja ou que tome um vulto maior - tem um custo muito baixo em relação ao custo da manutenção corretiva, que é aquela que se faz quando o problema já está instalado".

Segundo Bos (1989), a inclusão das atividades e valores inerentes ao uso e manutenção durante o planejamento e concepção do edifício viabiliza a tomada de decisões mais adequadas, tais como aquelas que consideram o design espacial e a seleção dos materiais e equipamentos mais adequados. $O$ autor elucida também que a análise integrada de suas fases permite a aplicação mais equilibrada dos recursos ao longo do ciclo de vida do edifício, sendo essencial o entendimento dos parâmetros considerados para os custos de operação, tais como a conservação de energia, a limpeza, a segurança, a manutenção física e reparos (MEDEIROS, 2006).

\subsubsection{Condomínio fora do Brasil}

De acordo com J.B. Lopes (2006), de modo geral, todos os países admitem o instituto da propriedade horizontal/ condomínio edilício. Em sua obra "Condomínio", o autor examina e faz considerações sobre algumas legislações estrangeiras a respeito do assunto que serão brevemente apontadas neste trabalho ${ }^{29}$.

O autor inicia sua análise com o direito francês, em que o condomínio é regulado pela Lei 65-557 de 10/07/1965 e pelo Decreto 67-223 de 17/03/1967, que têm como objetivos a valorização do patrimônio comum através do aperfeiçoamento

\footnotetext{
${ }^{29}$ A pesquisa relacionada à experiência internacional de condomínios é bastante ampla e será resumida neste trabalho devido à sua complexidade e quantidade de informações existentes. $\mathrm{O}$ autor acima referido faz um panorama breve sobre o assunto em seu livro "O condomínio" e por isso será o único autor a ser citado. Para mais informações, ver: GIVERDON, Claude; GIVORD, François. La copropriété. Paris: Dalloz, 1974. BENACCHIO, Giuseppe. Il condomínio edilizio. Turim, 1969. CUNHA GONÇALVES, Luís. Da propriedade horizontal ou por andares. Lisboa: Ática, 1956. RACCIATTI, Hernán. Propriedad por pisos o por departamentos. Buenos Aires: Depalma, 1975.
} 
de sua administração e melhor regulamentação das assembléias; a salvaguarda dos direitos individuais; a preocupação de se evitarem litígios e a personalização do sindicato dos condôminos, denominado syndicat, o qual possui personalidade jurídica, apresentando-se como entidade sui generis, diferente dos sindicatos profissionais (LOPES, J.B., 2006).

Outros pontos importantes da legislação francesa são a consagração do direito de sobrelevação em que o proprietário possui o direito de construir sobre um edifício pertencente a outro acrescentando-lhe vários andares ${ }^{30}$, e a preocupação com a fiscalização das atividades do síndico - syndic - considerado "agent officiel $d u$ syndicat" (LOPES, J.B., 2006).

$\mathrm{Na}$ Itália, o instituto do condomínio é regulado pelo Código Civil de 1942, artigos 1.117 a 1.139 , e tem a preocupação de discriminar, minuciosamente, as partes comuns do edifício para evitar possíveis dúvidas de interpretação, tratando separadamente do solo, fundação, paredes mestras, teto, escadas, portaria, pátios, alojamento do porteiro, aquecimento central, instalações comuns etc.

Além disso, a legislação também trata do direito de sobrelevação ao proprietário do último andar e isenta de contribuição os condôminos dissidentes no que diz respeito a obras voluptuárias ou muito gravosas, se não os beneficiarem (LOPES, J.B., 2006).

Ainda segundo J. B. Lopes (2006), na Espanha, a antiga lei de 21/07/1960 reguladora dos condomínios já continha dispositivos de caráter geral e normas específicas sobre a propriedade horizontal, em que foram fixadas as atribuições da "Junta de propietários" e de um presidente que os representa em juízo e fora dele. A recente Lei 8/1999 complementa a antiga, pois disciplinou o regime das convocações das assembléias, reduziu as hipóteses de exigência de unanimidade nas votações, criou o fundo de reserva, entre outros.

Em Portugal, a propriedade horizontal é disciplinada pelo Código Civil em seus artigos 1.414 e seguintes, alguns dos quais recentemente alterados pelo Decreto-Lei 267, de 25/10/1994. Este decreto introduziu algumas inovações, como a possibilidade de obras que modifiquem a linha arquitetônica ou o arranjo estético do edifício, quando aprovadas por maioria representativa de dois terços do valor total do prédio; a sujeição ao pagamento das despesas dos condôminos que não hajam

\footnotetext{
${ }^{30}$ LOUREIRO, 2004.
} 
aprovado as inovações; permissão ao condômino de fazer reparações urgentes, se omisso o administrador; e a disposição que dispensa de contribuir para as despesas com elevadores os condôminos que por eles não são servidos (LOPES, J.B., 2006).

Vale ainda fazer referência à moderna legislação argentina que, por meio da lei 13.512/1949 enumera cuidadosamente as partes comuns, proíbe a sobrelevação, salvo à concordância de todos os demais condôminos, e dispõe sobre a "pena de arresto" que prevê até vinte dias de multa imposta ao condômino que se comportar contra a moral, bons costumes ou perturbar a segurança e a tranqüilidade dos demais condôminos (LOPES, J.B., 2006).

\subsubsection{Tipos de Gestão Condominial}

A administração ou gestão condominial de um edifício engloba questões físicas, jurídicas, operacionais, contábeis, sociais e culturais. Gerenciar um condomínio significa agregar todas estas questões de maneira que a convivência entre os condôminos seja regulamentada, e conseqüentemente harmonizada (SCHWARTZ, 2007).

Gerenciar as relações que envolvem um condomínio é algo complexo, pois exige um certo grau de conhecimento técnico, sob pena de se praticarem enganos, equívocos e injustiças, normalmente sob pressões e conflitos dos moradores e agentes externos envolvidos (SCHWARTZ, 2007).

Há várias formas de gestão condominiais implantadas nos edifícios brasileiros, entre elas:

1) Gestão terceirizada ou administração indireta: é o tipo de gestão mais comum, na qual o condomínio contrata uma administradora para assumir a responsabilidade pela execução das atividades burocráticas, operacionais, financeiras, administrativas, trabalhistas e jurídicas. O síndico continua a responder legalmente pelo condomínio e passa a ser o responsável pelas relações entre o condomínio e a administradora, contribuindo para que as medidas a serem adotadas estejam de acordo com as necessidades apresentadas pelos condôminos (CONTRERAS, 2001). As taxas cobradas por essas empresas variam entre 5 a 10\% 
sobre as despesas ou sobre as receitas do condomínio, dependendo do contrato (SCHWARTZ, 2007).

De acordo com a Associação das Administradoras de Bens Imóveis e Condomínios de São Paulo (AABIC), em uma gestão terceirizada, compete a uma administradora:

a) Gestão Administrativa. Exemplos: gerenciamento dos arquivos documentais e legais; presença nas assembléias (qualificação e controle das presenças, esclarecimento de dúvidas e redação das respectivas atas); transcrição das atas no livro próprio e registro no Cartório de Títulos e Documentos; elaboração das planilhas de concorrência e acompanhamento financeiro; controle do cadastro de proprietários; emissão e distribuição de cartas, circulares, editais de convocação e atas das Assembléias Gerais, entre outros.

b) Gestão de Recursos Humanos. Exemplos: recrutamento de funcionários; seleção de funcionários com pesquisa cadastral; treinamento interno e externo de funcionários com realização de cursos, palestras etc; atualização das carteiras profissionais; formalização de advertências disciplinares; confecção/ atualização do quadro de horário de trabalho; escala de revezamento e de férias - elaboração e controle; elaboração da folha de pagamento; elaboração e recolhimento das guias de INSS (GPS), entre outros.

c) Gestão Financeira. Exemplos: elaboração e acompanhamento da previsão orçamentária; elaboração do quadro de rateio das despesas; emissão dos recibos/ boletos bancários; cobrança administrativa de devedores - via carta e telefonemas; contas a pagar - controle dos vencimentos e emissão de cheques para a liquidação dos pagamentos; prestação de contas mensais ordinária, fundo de reserva, fundo de obras, fundo de custeio do $13^{\circ}$ salário etc., com elaboração de demonstrativos de pagamentos de despesas ordinárias, de recebimentos das cotas, dos devedores de cotas e balancete geral contendo a posição financeira do mês, entre outros. 
d) Assuntos jurídicos. Exemplos: atualização permanente da legislação que envolve a administração de condomínios; consultoria tributária, fiscal, civil e trabalhista; assessoria, na elaboração e alteração da Convenção de Condomínio; na elaboração e alteração de Regimentos Internos e na assinatura de contratos de prestação de serviços, de terceirização, de locação de espaços, entre outros.

2) Autogestão simples: os próprios condôminos se encarregam da administração do edifício, elegendo seus representantes por meio de uma comissão de moradores, sem necessidade de contratação de empresa especializada ou profissional externo. Os serviços no condomínio, tais como limpeza, jardinagem e segurança são realizados pelos moradores em um sistema organizado de revezamento. Na maioria dos casos, os moradores pertencentes à comissão não recebem salários pelos serviços prestados, sendo freqüente apenas ficarem isentos do pagamento do condomínio (SCHWARTZ, 2007). Tem como principais vantagens a redução das despesas condominiais, a transparência na contabilização dos gastos e a participação dos moradores. Os maiores problemas neste tipo de gestão podem ser o despreparo dos condôminos para o exercício das atividades e decisões que podem privilegiar o grupo mais participativo sem consultar os demais (LEME, 1996).

3) Autogestão com terceirização ou Co-gestão: os condôminos se organizam e contratam empresas para a realização de algumas atividades relacionadas com a operacionalização do condomínio. Podem vir a contratar terceiros para cuidar, por exemplo, da limpeza, jardinagem, segurança, entre outros, mas o condomínio continua sendo administrado pelos próprios condôminos por meio da autogestão. Este tipo de gestão exige que os representantes legais do condomínio, em especial o síndico, tenham boa capacidade de coordenação para administrar a passagem das informações e das tarefas de uma empresa a outra, sem deixar de estabelecer responsabilidades bem claras para cada uma (CONTRERAS, 2001).

4) Autogestão com assessoria: uma empresa de assessoria administrativa é contratada pelos moradores do condomínio com a função de orientar o uso do 
dinheiro do condomínio de acordo com a natureza das despesas, impedindo qualquer utilização indevida. Deve-se estar atento, pois a contratação deste suporte pode gerar custos similares ou maiores do que a taxa cobrada por uma administradora (CONTRERAS, 2001).

\subsubsection{Relações de vizinhança em condomínios}

O Código Civil dispõe sobre regras gerais de uso das partes comuns e exclusivas que devem ser seguidas por todos os condôminos. Entretanto, cada condomínio possui sua Convenção e Regimento Interno, onde são listadas todas as regras específicas para aquele edifício.

Fatores como o uso da garagem, o horário de funcionamento da piscina ou do salão de festas, horário para mudanças e obras, permanência de animais domésticos e acesso de visitantes devem estar regulamentados em pelo menos um dos dois documentos (SCHWARTZ, 2007).

Além do respeito às leis ou normas, é fundamental para a vida em condomínio que sejam usadas as regras da boa educação, da tolerância e que se exercite o direito e a obrigação de zelar pelo que é de todos (CONTRERAS, 2001).

Segundo o professor Francisco Menna Barreto Reis ${ }^{31}$, "A vida condominial deve ser pautada nas relações de boa convivência, em que as pessoas se sintam protegidas, seguras e tratadas com dignidade. Onde as pessoas se queiram bem, preservando a gerência dos atos e fatos contábeis e materiais, mas sem prejuízo para as relações humanas. Onde crianças, idosos, mulheres, gestantes, portadores de necessidades especiais e visitantes sejam tratados com respeito e dignidade".

Em pesquisa realizada pelo Sindicato dos Condomínios Residenciais e Comerciais do Distrito Federal $^{32}$, as maiores dificuldades encontradas para se administrar um condomínio são, em primeiro lugar, o gerenciamento de receitas e despesas e, em segundo lugar, o relacionamento com os moradores.

Segundo Leme (1995), os problemas de condomínios residenciais são justamente essa convivência entre os dois espaços: a unidade residencial, relação

\footnotetext{
${ }^{31}$ Em entrevista ao portal http://aspcondominios.com.br acessada em 19/09/2007.

32 http://www.sindicondominio.com.br acessado em 16/09/2007.
} 
íntima, emocional que se tem com a casa; e o espaço comum, próprio a esse tipo de habitação, e responsável pelas maiores dificuldades de aceitação do modo de viver em apartamentos.

Existe uma natural recusa em obedecer a regras externas dentro de espaços privados, assim como em partilhar o local de moradia. O condomínio pode ser visto como uma conexão entre o público e o privado $^{33}$, lócus de conflitos à medida que, ao sair da unidade residencial privativa e sem ainda ter atingido a rua, espaço público, pisa-se o "espaço comum" que, segundo Damatta (2003), é um lugar que tem regras e normas que devem ser observadas, de onde se é um co-proprietário, uma figura jurídica com direitos limitados e deveres disciplinados pela legislação (LEME, 1995).

Nos espaços comuns de um edifício residencial, os moradores têm direitos limitados, pois devem seguir uma série de regras pré-estabelecidas pelo grupo na Convenção e no Regimento Interno do condomínio. Já em sua área privativa, seus direitos são ilimitados e as regras podem ser alteradas por ele a qualquer momento, desde que não interfira no espaço comum ou prejudique de alguma forma os outros moradores.

Leme (1995) afirma que o viver em condomínio ainda não foi totalmente assimilado pela sociedade brasileira. Existe a nostalgia da casa, do espaço privado próprio indiscutível e das tradições e lembranças que a legitimam. O conceito de viver em apartamento vem romper com essas imagens fixadas no inconsciente, colocando uma realidade que se opõe a um arquétipo de moradia que os homens desenvolveram através da história.

De acordo com Motta (1975), habitar um edifício pressupõe certas diferenças em relação ao padrão de comportamento do homem no meio urbano. Da própria natureza dos edifícios residenciais, deduz-se que se procure organizar em seu interior uma vida em que os moradores estejam relativamente integrados entre si. Viver num conjunto habitacional implicaria, portanto, numa certa coesão entre os usuários. Entretanto, o modo de vida urbano implica exatamente no oposto deste princípio de "harmonia social".

Anderson (1968) apud Motta (1975) define o modo de vida urbano: "o homem urbanizado orienta-se entre a multidão. Não se perturba ante o ir e vir das pessoas. A transitoriedade é uma das suas características. Não pode conhecer bem todas as

\footnotetext{
${ }^{33}$ Público no sentido de espaço comum e privado no sentido de espaço particular.
} 
pessoas que se relacionam com ele e talvez nem mesmo deseje. Assim sendo, as relações interpessoais são marcadas pela superficialidade. Como o homem urbano não pode conhecer todas as pessoas - nem tampouco quer - adquire a capacidade de mover-se entre a multidão, sem se preocupar com quem está a seu lado e sem evitar a aproximação, sendo sua terceira característica o anonimato".

O ponto de vista de Anderson (1968) contrasta com o princípio de "integração social" dos condomínios residenciais. Motta (1975) aponta que esta integração, por sua vez, só poderá ser atingida através da rigorosa planificação habitacional, especialmente no que se refere à utilização de equipamentos coletivos que fortaleçam as relações interfamiliares.

Sendo assim, entende-se que os condomínios possuem regras, estabelecidas pelos próprios usuários, e que devem ser seguidas por todos. É importante que cada condômino saiba os motivos que o levaram a fazer parte deste grupo e tenham consciência de que são como peças que integram um todo, com direitos e obrigações.

\subsection{Gestão Pós-Ocupação em edifícios reabilitados para HIS}

Como já citado no início deste capítulo, a gestão pós-ocupação de um edifício tem como meta controlar as atividades e acontecimentos ocorridos no período de uso e ocupação do prédio, relacionados tanto ao edifício quanto a seus usuários, garantindo a realização do objetivo inicial planejado para a edificação.

Nos edifícios voltados para HIS, o principal objetivo estipulado no momento do planejamento do programa habitacional é promover unidades habitacionais para certa faixa da população, garantindo a sustentabilidade social, econômica e física, tanto do edifício quanto de seus usuários.

Sustentabilidade, segundo a Comissão Mundial sobre Meio Ambiente e Desenvolvimento (CMMAD) da Organização das Nações Unidas (ONU), tem a seguinte definição: aquilo que atende às necessidades presentes sem comprometer a possibilidade de as gerações futuras satisfazerem as suas próprias necessidades (CMMAD, 1991). 
De acordo com Stren and Polèse (2000), a sustentabilidade de um local ou mesmo de um edifício pode ser entendida como uma forma de desenvolvimento que busca harmonizar os diversos grupos sociais e culturais existentes em um mesmo local por meio de melhorias na qualidade de vida. Aspectos econômicos da população e construtivos do edifício interferem na sustentabilidade do local e devem ser levados em consideração desde o início do projeto.

Para Stren and Polèse (2000), é necessário entender que cada edifício possui um contexto diferente. Estes contextos agregam diversas características gerais e específicas do local e dos usuários que possibilitarão ou não a existência da chamada sustentabilidade (Figura 3.1).

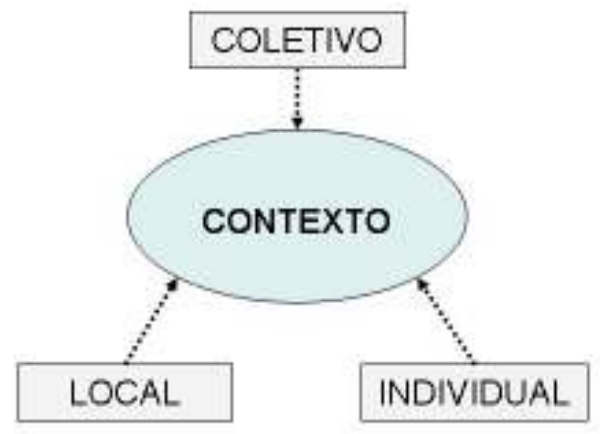

Figura 3.1 0 contexto do edifício e as características específicas o local e dos usuários. Fonte: Stren and Polèse (2000)

A primeira característica que compõe o contexto de um edifício é o local de implantação e todas as variáveis físicas que podem influenciar o entorno, seja o ambiente construído, o sistema de transportes, a infra-estrutura e os serviços existentes, entre outras.

A segunda característica está diretamente relacionada ao usuário e suas referências. Os aspectos individuais do morador, tais como características sociais, culturais, aspectos financeiros e percepções subjetivas podem interferir diretamente nas relações existentes e, por conseqüência, na sustentabilidade do local. Por último, os autores destacam o aspecto coletivo, o qual está relacionado com a integração existente entre os usuários, com suas características individuais, e o local. Esta integração pode ser medida por meio da existência de participação, colaboração e inclusão social.

Além dos três aspectos citados acima, a gestão pós-ocupação de edifícios habitacionais reabilitados voltados para HIS possui outras variáveis que a caracterizam e diferenciam de outras gestões. 
A primeira variável importante a ser destacada é a propriedade do imóvel. Conforme apresentado no capítulo dois desta dissertação, no Programa de Arrendamento Residencial (PAR) da CEF, o morador paga as parcelas do arrendamento por 15 anos como se fosse um aluguel e após este período tem o direito de adquirir ou não a unidade. Durante esse tempo, o arrendatário não é considerado o proprietário do imóvel, e sim a CEF. Este fator é responsável por diversas mudanças nas atribuições das instâncias responsáveis e na relação do morador com a residência.

No âmbito do órgão promotor, a gestão demanda o estabelecimento de definições normativas e estruturas institucionais de regulação, coordenação e administração do processo de manutenção e conservação das unidades habitacionais e dos equipamentos de uso comum. A existência de um conjunto de edifícios habitacionais exige agilidade e eficiência do órgão promotor para manter, conservar e recuperar os edifícios, prevenindo-se a deterioração das unidades habitacionais e das áreas comuns dos prédios (Instituto de Estudos Especiais - IEE, 2006).

Para o morador, esta variável envolve o significado da moradia e o valor atribuído à casa própria em nossa sociedade. A casa representa não apenas o espaço da privacidade e da sociabilidade familiar, mas também o abrigo contra as inseguranças do sistema econômico.

O antropólogo Roberto Damatta, em sua obra "A Casa \& A Rua" (1997) completa: "Quando digo que 'casa' e 'rua' são categorias sociológicas para os brasileiros, estou afirmando que, entre nós, estas palavras não designam simplesmente espaços geográficos ou coisas físicas comensuráveis, mas acima de tudo entidades morais, esferas de ação social, províncias éticas dotadas de positividade, domínios culturais institucionalizados e, por causa disso, capazes de despertar emoções, reações, leis, orações, músicas e imagens esteticamente emolduradas e inspiradas".

A sensação de não ser o proprietário do imóvel é freqüente para a maioria dos moradores e acaba sendo refletida no tratamento dado nas unidades habitacionais e nas áreas comuns dos edifícios. A população residente muitas vezes não se apropria destas áreas, que acabam sendo deterioradas e até vandalizadas. 
De acordo com Leme (1995), "existem diferentes concepções do que seja espaço comum: enquanto alguns o vêem como se fosse terra de ninguém, $e$, portanto passível de ser apropriado, outros o encaram como aquilo que não sendo de ninguém pode ser destruído; é visto como um local que pode abrigar o protesto porque é de 'todo mundo', mas poucos o têm como um espaço nosso".

A segunda variável que caracteriza a gestão destes edifícios é a escolha do tipo de gestão condominial empregada. Os imóveis arrendados são administrados pela CEF por meio do PAR e são um patrimônio do Fundo de Arrendamento Residencial (FAR). O condomínio é instalado e a gestão condominial, determinada pela CEF, é terceirizada, ou seja, é feita por uma empresa administradora de condomínios escolhida pela CEF por meio de licitação. Esta empresa passa a administrar o condomínio e a ser o síndico do edifício, direito transferido pela CEF.

A única participação dos moradores na gestão condominial ocorre através de um conselho fiscal, que, eleito pelos moradores, acompanha as receitas e as despesas do prédio junto à administradora.

A terceira variável que acaba também por interfer na gestão destes edifícios é a ausência do Trabalho Técnico Social (TTS) obrigatório realizado pela CEF. Todos os edifícios do PAR possuem, obrigatoriamente, um trabalho social feito por técnicos credenciados, com duração máxima de seis meses.

Entretanto, dos cinco edifícios reabilitados pelo PAR, somente dois (Fernão Salles e Riskallah Jorge) possuem o registro deste trabalho. De acordo com a CEF, o motivo para a ausência deste acompanhamento social é a existência de uma forte liderança dentro dos prédios, proveniente dos movimentos sociais, que não aceita o TTS com os moradores (informação verbal) ${ }^{34}$.

Além das questões apresentadas, outras características importantes na GPO de edifícios reabilitados voltados para HIS, relacionadas tanto com a população beneficiária quanto com a edificação, devem ser apontadas a fim de que se entenda quais são efetivamente os pontos importantes e característicos da demanda e das unidades habitacionais ofertadas.

\footnotetext{
${ }^{34}$ Informação fornecida pela técnica social Célia Teixeira em entrevista realizada em 22 de junho 2007.
} 


\subsubsection{Aspectos sociais e culturais da população moradora}

Os conflitos encontrados em conjuntos habitacionais para população de baixa renda são, antes de tudo, sociais e culturais, pois envolvem pessoas que possuem acentuados problemas de inserção social e urbana. Trata-se de famílias cujas características sócio-demográficas e de história de vida conduzem a situações de pobreza crônica, dificuldade de inserção na vida ativa urbana e, por vezes, numa vida comunitária sem relações de vizinhança (IEE, 2006).

As famílias que habitam as moradias sociais geralmente são numerosas e possuem baixo nível de escolaridade. Stechhahn (1990), em sua pesquisa em conjuntos habitacionais para HIS, afirma que "com certa freqüência, os dados levantados revelam que as unidades habitacionais apresentam problemas de superlotação, sobretudo pelo número elevado de filhos e/ou por condições específicas da família, que se vê na obrigação de acolher parentes próximos (...) A superpopulação cria atritos e constrangimentos constantes, onde a sobreposição de atividades não permite a organização e manutenção da casa. O processo de apropriação não se estabelece no caos, onde cada membro da família não possui efetivamente um lugar, mas apenas um espaço para durante uma parte do dia poder comer e dormir. Nestas condições, não existe possibilidade de se estabelecer uma identificação entre o usuário e o espaço, porque simplesmente ele não consegue se apropriar desse espaço".

Outras características comuns são desemprego, alcoolismo, tráfico de drogas e prostituição, o que acaba afastando da vida ativa as diferentes gerações ou quando muito de uma vida ativa segura e razoavelmente remunerada. Trata-se, pois, de uma população heterogênea, composta por grupos sociais com diferentes vulnerabilidades, experiências de vida, inserções ocupacionais e de moradia, apresentando ainda dinâmicas específicas no interior de cada um desses segmentos sociais (IEE, 2006).

De acordo com Coelho (1999), em estudo feito sobre a gestão integrada de parques habitacionais de arrendamento público em Portugal, “(...) neste quadro socialmente problemático, embora com diferentes graus de intensidade de extensão, geram-se climas sociopsicológicos negativos com perda de auto-estima e de apreço pelo seu quadro urbano de residência. Este clima acentua a interpretação pessimista face ao passado e ao futuro, valorizando a aceitação da pobreza como destino e 
como estigma cultural do qual as saídas são breves e as recaídas uma fatalidade duradoura".

Concomitantemente a este quadro, existe uma diferenciação cultural fruto do confronto de culturas, mais urbanas ou mais rurais, de gerações diferentes, chegando até a confrontos de diferentes etnias e suas características específicas. Este mosaico cultural pode vir a ser um fator de crises e tensões, fruto do clima de dificuldades em que estes grupos vivem. Contudo, conforme analisa Coelho (1999), o resultado desta mescla poderia ser positivo, pois a diferenciação é sempre um fator importante para criar dinâmicas sociais bastante ricas visando processos de desenvolvimento sócio-urbanístico para esta população.

As famílias que utilizam as habitações sociais geralmente são provenientes de favelas, cortiços ou moradias coletivas precárias existentes em cômodos, prédios, pátios, quintais, pensões, quitinetes, galpões e barracões, sempre com a coabitação de diversas famílias, indivíduos sós ou grupos de pessoas que se associam para dividir custos de moradia e que ocupam cômodos alugados ${ }^{35}$ (IEE, 2006).

$\mathrm{Na}$ maioria das vezes, a população não possui conhecimento relativo à divisão dos cômodos de uma residência e suas hierarquias de uso. Nos cortiços e favelas, estes usos são sobrepostos e quase sempre adaptados às necessidades daquela família, não existindo áreas comuns e coletivas (IEE, 2006).

De acordo com Leme (1995), o arquétipo de moradia é a casa, que associa os valores de liberdade, privacidade e propriedade. As regras do morar em casa estão no inconsciente das pessoas quando falam minha casa para o apartamento. $\mathrm{O}$ apartamento é um outro conceito de morar, com novas regras que pedem novas formas de comportamento. E isso não é ensinado, suas regras não são transmitidas, precisam ser descobertas, às custas de muitos desentendimentos e requerem muita sensibilidade e observação (LEME, 1995).

Viver em um edifício composto por áreas privativas e áreas públicas, como uma nova condição de moradia, até então realizada em cortiços e favelas, transforma a rotina desta população que é inserida nesse novo local, onde existem

\footnotetext{
${ }^{35}$ A precariedade habitacional neste tipo de habitação pode ser verificada pelo adensamento e o congestionamento dos ambientes, pela insuficiência dos equipamentos sanitários e hidráulicos (banheiros, pias, lavatórios, cozinhas), pela insalubridade, falta de ventilação, barulho excessivo, ausência de privacidade, entre outras coisas (IEE/ 2006).
} 
outras regras, situações e relações sociais, que até o momento eram desconhecidas.

\subsubsection{Aspectos econômico-financeiros da população moradora}

Ao tratar de habitação de interesse social, a questão econômico-financeira passa a ser uma condição inerente. Os programas habitacionais selecionam a população beneficiária por meio da renda mensal do chefe de família, que, por ser muito reduzida, não é suficiente para se comprometer com parcelas de financiamento ou mesmo locação de uma unidade no mercado (COELHO, 1999).

O Estado promove HIS para esta parcela da população, que por insolvência econômica necessita de apoio financeiro significativo do setor público para ter acesso à habitação.

A definição de subsídio muitas vezes é confundida com dar ou receber alguma coisa gratuitamente, sendo esta uma compreensão errônea. Hoek-Smit; Diamond (2003) definem subsídio como "[...] um incentivo dado pelo governo para possibilitar e persuadir uma certa classe de produtores ou consumidores a fazer alguma coisa que, de outra forma, eles não fariam, pela diminuição do custo de oportunidades ou pelo aumento dos benefícios potenciais de fazê-lo". Os subsídios, sejam na forma de compra ou reforma, tornam-se então ferramentas fundamentais para possibilitar o acesso à habitação para a população de baixa renda, chegando às vezes também para a de média renda.

As famílias beneficiadas, muitas vezes numerosas, compõem-se de cidadãos ativos e inativos, sendo que os ativos recebem baixos salários ou rendimentos em empregos de reduzida estabilidade e rentabilidade (COELHO, 1999).

Esta população é constituída por indivíduos e grupos sociais inseridos socialmente por meio do trabalho precário, dos serviços de curta duração, do trabalho doméstico e de limpeza (quase sempre não regularizado e de baixa remuneração), do pequeno comércio de rua (vendedores ambulantes, marreteiros), do setor de serviços mal pagos etc (IEE, 2006). Para estas famílias, a renda familiar mensal pode ser algo muito instável, o que pode prejudicar a adimplência das taxas existentes em um condomínio. 
Morar em um edifício verticalizado acarreta diversos custos antes não existentes aos moradores. Entre eles:

1) Taxas do programa habitacional: podem ser parcelas de financiamento, parcelas de arrendamento ou locação social, sendo estas altamente subsidiadas.

2) Taxas condominiais: de acordo com o novo Código Civil, é dever do condômino contribuir para as despesas do condomínio na proporção das suas frações ideais. Os gastos mensais em um edifício são as chamadas despesas com administração, que se destinam a cobrir gastos com a conservação e funcionamento do edifício, inclusive reparações nas partes comuns, para manter-lhe as condições normais de segurança, conforto etc. Esta taxa geralmente é dividida entre: pessoal, água, luz, elevadores, taxa de administração, manutenção, entre outros. Para edifícios de habitação social a taxa varia de acordo com o tipo do programa, sendo que nos edifícios aqui estudados pode chegar a R\$ 200 (SCHWARTZ, 2007).

3) Manutenção do imóvel: gastos com possíveis reparos nas unidades habitacionais decorrentes da má construção ou da má utilização pelos usuários, ou ainda do desgaste pelo uso. Geralmente os gastos estão incluídos nos seguintes grupos de serviços: instalações hidro-sanitárias, instalações elétricas, alvenarias, esquadrias, pisos, forros, revestimentos e pintura.

4) Manutenção das áreas comuns: manutenção dos elevadores, caixa d'água, entre outros.

De acordo com Ceotto (2007), dentro do ciclo de vida de um edifício, a fase de uso e operação representa aproximadamente $80 \%$ do custo total do edifício, conforme gráfico a seguir (Gráfico 3.2): 


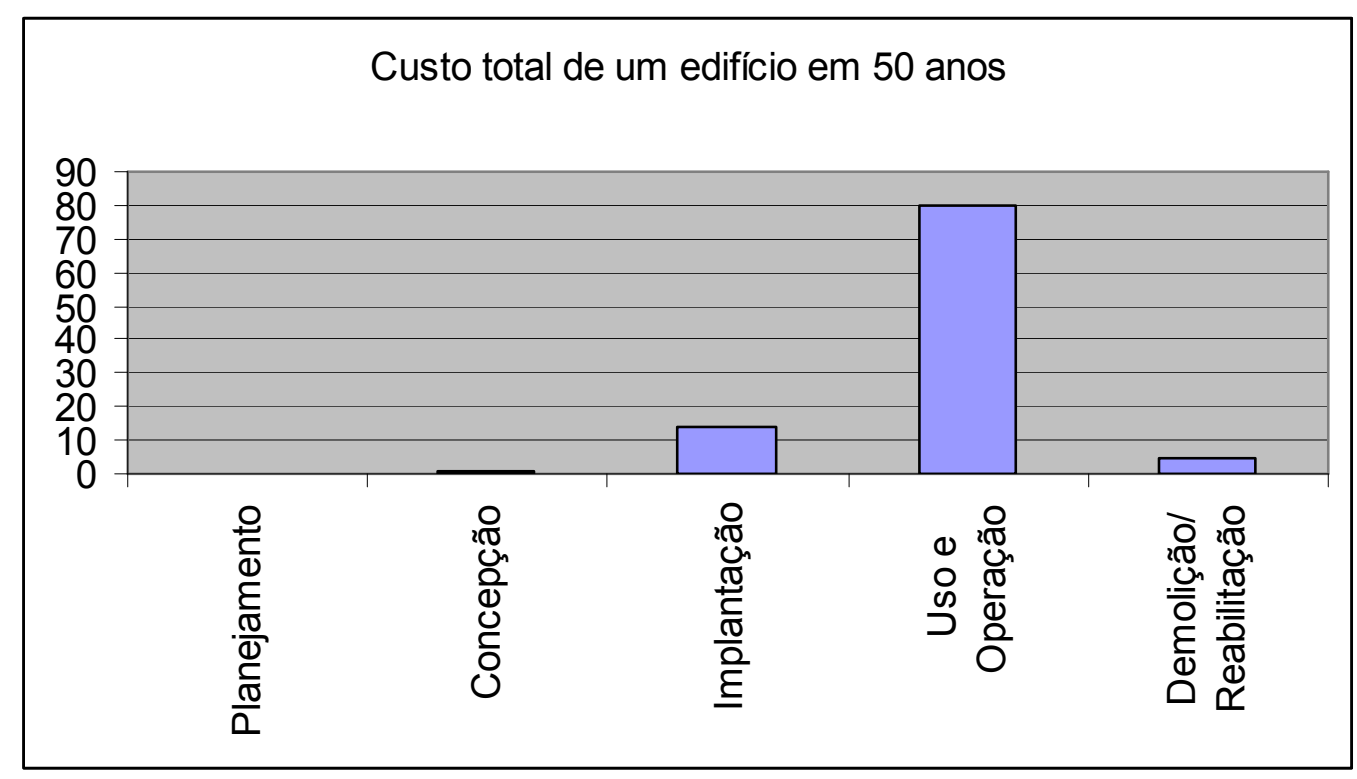

Gráfico 3.2 Custo total de um edifício em 50 anos.

Fonte: Ceotto, 2007.

A fase de uso e ocupação engloba custos de manutenção da unidade e do edifício como um todo. Estudos realizados em diversos países para diferentes tipos de edifícios demonstram que os custos anuais envolvidos na operação e manutenção das edificações em uso variam entre $1 \%$ e $2 \%$ do seu custo inicial (ABNT, 1999; JOHN, 1988; LEE, 1988). Este valor pode parecer pequeno, porém, acumulado ao longo da vida útil do edifício, chega a ser equivalente ou mesmo superior ao seu custo de construção.

Um dos principais objetivos dos programas habitacionais é alcançar a sustentabilidade econômica por meio da manutenção da adimplência tanto das parcelas de financiamento/ arrendamento/ locação quanto das taxas condominiais (COELHO, 1999).

A inadimplência das parcelas referentes à habitação, assim como das taxas condominiais, é bastante elevada em diversos programas para habitação social, o que muitas vezes leva as famílias a deixar o programa e voltar para a antiga solução habitacional, seja favelas, cortiços ou mesmo as ruas, devido à impossibilidade de arcar com as dívidas ${ }^{36}$ (REABILITA, 2007).

\footnotetext{
${ }^{36}$ Como exemplo, quando um arrendatário do PAR não consegue pagar as taxas de arrendamento, a CAIXA entra na Justiça com um pedido de reintegração do imóvel para que ele seja repassado para outro interessado. Entretanto, o PAR procura orientar a família, junto ao poder judiciário, a procurar um outro programa de habitação em que o perfil da família se encaixe. Ressalta-se também que o PAR é um programa de arrendamento, o que de certa maneira facilita à CAIXA o deslocamento do morador inadimplente para outra unidade de menor valor (REABILITA, 2007).
} 


\subsubsection{Aspectos físico-construtivos dos edifícios}

As características das obras de reabilitação são, em grande parte, distintas daquelas encontradas em construções novas e geralmente implicam em elevada complexidade na logística e administração do canteiro de obras (REABILITA, 2007).

No Brasil, a política de reabilitação de edifícios vazios para habitação é recente. Na maioria dos casos, são os órgãos públicos que investem sobre o subsetor de reabilitação, sendo que as ações neste sentido ainda são pontuais e não seguem uma metodologia consolidada. O desconhecimento por parte das construtoras quanto às particularidades envolvidas em obras de reabilitação é uma realidade, sendo que nestas ainda são aplicados métodos construtivos tradicionais utilizados em construções novas, o que de fato conduz a vários problemas, desde a gestão da obra, passando pela geração e deposição desordenada de resíduos, até o não atendimento às exigências feitas pelos usuários em termos de desempenho global do edifício (MARQUES DE JESUS, 2008).

O projeto de reabilitação de edifícios busca adaptar uma edificação já existente para um novo uso, neste caso, habitacional. O projeto muitas vezes não é padronizado nos andares devido a certos imprevistos decorrentes das adaptações realizadas, como por exemplo, a presença de vigas e pilares não constantes nos projetos originais, alvenaria estrutural em algumas vedações, condições dos materiais piores do que o verificado no diagnóstico inicial, entre outros (REABILITA, 2007).

A localização em áreas de preservação de patrimônio histórico é outro fator que caracteriza este tipo de obra. De acordo com Projeto Reabilita (2007), nos edifícios reabilitados em São Paulo, a preservação se dá em vários níveis, podendo ser, por exemplo, tombamento volumétrico ou somente da fachada, o que acaba refletindo diretamente na obra e na utilização pelos usuários. A impossibilidade de troca das esquadrias da fachada devido ao tombamento, por exemplo, pode implicar em problemas de funcionamento durante o uso dos novos moradores devido aos desgastes provocados no material com o passar do tempo.

Outro fator que caracteriza este tipo de prédio é a existência de elevadores reformados. Devido ao alto custo dos equipamentos novos e ao orçamento enxuto existente para estas obras, somente a reforma dos elevadores pode ser viabilizada. Este procedimento é utilizado em diversas obras, porém, a necessidade de 
manutenção periódica dos equipamentos é bastante elevada, acarretando custos futuros para o condomínio.

Estas características, específicas dos edifícios reabilitados, aumentam ainda mais a necessidade de cuidados com o uso e operação da edificação. A informação sobre os cuidados e necessidades de manutenção dos sistemas do prédio deve estar à disposição dos usuários desde o momento da entrada no edifício.

Por este motivo, o fornecimento das plantas de cada unidade e de manuais de uso indicando os procedimentos operacionais dos equipamentos existentes na edificação (como elevadores e lavanderias), além das necessidades relativas à limpeza e segurança das áreas privativas e comuns, é de extrema importância para os moradores. Os manuais destinados aos usuários devem conter as especificações quanto à garantia dos serviços e dos materiais, com as orientações e informações fornecidas previamente pelos fabricantes (MESQUITA, 2006).

Segundo Mesquita (2006), é importante lembrar que não basta projetar e executar o empreendimento de um edifício de modo adequado, é necessário também garantir que sua utilização seja apropriada. Isso significa planejar sua fase de utilização, que envolve o uso, operação e manutenção do mesmo.

Ainda segundo a autora, é necessário chamar a atenção para o fato de que a vida útil do edifício é prolongada, sobretudo devido à adequada operação por parte de seus usuários, que podem ser aqueles envolvidos diretamente com o edifício, utilizando-o constantemente, e os usuários externos, vizinhança, meio ambiente etc.

Deve-se observar, portanto, a necessidade de se consolidar, ainda na fase de concepção, a inclusão de práticas e valores ligados à fase de utilização do edifício, tais como o fornecimento de documentação e de dados de apoio sobre esta atividade. Muitas vezes estas famílias nunca viveram em uma casa ou apartamento que tivesse instalações elétricas e hidráulicas deste tipo ou em locais em que fosse realizado algum tipo de manutenção periódica. Esta falta de informação acaba gerando um uso de maneira equivocada das partes do edifício.

A cultura da manutenção é algo muito recente na sociedade brasileira. Técnicas e políticas de conservação quase nunca fizeram parte das políticas públicas do país e somente agora começam a entrar nas discussões. Conforme analisa Bezerra (2000), a manutenção das edificações envolve conhecimentos técnicos e procedimentos administrativos, sendo que a finalidade principal é 
conservar as características de segurança, funcionalidade, confiabilidade, higiene e o mesmo padrão de conforto de quando o imóvel foi entregue para uso.

Entretanto, todas estas ações de manutenção acarretam custos para os futuros moradores, que, nos edifícios reabilitados, conforme já citado anteriormente, são famílias cujas características sócio-econômicas e de história de vida conduzem a situações de pobreza.

\subsubsection{Aspectos arquitetônicos e urbanísticos dos edifícios}

A elaboração de um projeto de reabilitação de edifícios é diferente da de um projeto de edificações novas, uma vez que o mesmo é feito a partir de uma edificação já construída e que pode ainda ter sofrido intervenções em relação ao projeto original.

Estas edificações foram executadas a partir de programas e legislações vigentes no momento específico de sua elaboração, sob um contexto de necessidades e de soluções também específicas. A adequação às novas necessidades, às novas regulamentações e a um novo contexto urbano é extremamente complexa. Além disso, a elaboração do projeto é contínua ao longo da obra, uma vez que durante a sua execução surgem situações não previstas no diagnóstico, sendo necessárias alterações no projeto (REABILITA, 2007).

Os projetos de edifícios habitacionais reabilitados para HIS propõem adaptações ao edifício existente, buscando atender ao maior número de unidades habitacionais possíveis dentro dessa estrutura já edificada existente.

Em muitos casos, devido a esta necessidade de adequação, os espaços concebidos são impostos, não permitindo qualquer forma de participação prévia por parte dos futuros moradores, além de dificultar e talvez até distanciar, cada vez mais, a possibilidade de apropriação dos espaços pelos usuários (STECHHAHN, 1990).

Para Stechhahn (1990), a obra arquitetônica vista desde seu aspecto morfológico, físico e funcional é signo das necessidades do homem. Sem as informações e percepções sobre as atividades cotidianas do usuário, suas 
necessidades, prioridades e desejos, o arquiteto, possivelmente, não conseguirá realizar o projeto com sucesso.

A maioria da população, sem alternativa, aceita estes espaços, que não refletem suas reais necessidades, e, com o passar do tempo, moldam e interferem nos locais até conseguirem representar seus reais valores sócio-econômicos e culturais. Pouco a pouco, vão surgindo marcas da ação do usuário, que transforma o espaço a fim de moldá-lo às suas necessidades físicas e psíquicas (STECHHAHN, 1990).

Uma característica dos edifícios para HIS é a grande utilização das áreas comuns do prédio devido ao tamanho reduzido das unidades habitacionais já que há necessidade do órgão promotor de promover o maior número de habitações possíveis na área (STECHHAHN, 1990).

O espaço comum ou coletivo nos edifícios habitacionais, é o elemento de transição entre a unidade habitacional e o espaço público. De acordo com Freyre (1979): "O espaço imediato em torno da residência - seja esta a casa individual, ou parte de um conjunto, sob a forma de apartamento dentro de edifício - completa, amplia, integra a residência num todo além de residencial. Todo que pode ser definido como supercasa. Que deixa de ser privado, para ser público. Solidário. Comunitário".

A qualidade dos espaços coletivos propostos pelo arquiteto em um projeto ou a certeza de que serão utilizados só poderão ser verificadas após um período de ocupação e uso dos moradores, que possivelmente farão adaptações de acordo com suas reais necessidades. As transformações dos espaços podem estar relacionadas ao aumento das áreas construídas das unidades utilizando espaços coletivos; ao parcelamento e ocupação dos espaços previstos como livres de edificações, privatizando-se individualmente ou coletivamente os espaços públicos; e à re-hierarquização dos espaços públicos, alterando seu desenho e estabelecendo padrões mais adequados às necessidades e possibilidades da população com propostas distintas das originais (RIGATTI, 1997 apud NAVAZINAS, 2007).

$\mathrm{Na}$ maioria dos projetos elaborados para os edifícios reabilitados, as áreas coletivas propostas se resumem a lavanderias coletivas e salões comunitários, devido à escassez de espaços determinados para as atividades de lazer nestes prédios. 
Outra característica importante dos edifícios reabilitados de São Paulo é sua localização. Os prédios localizam-se na região central da cidade, e estão totalmente inseridos no tecido urbano, sendo a acessibilidade sua maior qualidade.

A acessibilidade tem relação direta com a facilidade com que os indivíduos se deslocam para os locais de emprego, lazer, cultura, atendimento à saúde e equipamentos públicos em geral (ZANDONADE, 2005).

Entretanto, a inserção dos moradores na chamada rede de relações sociais existente no entorno da nova moradia é algo de extrema importância para que o programa alcance seus objetivos. A rede de relações sociais inclui o acesso aos direitos básicos, como matrícula de crianças e jovens em escolas e creches, atendimento das necessidades básicas de pessoas idosas e pessoas com deficiências, acesso ao atendimento na rede pública de saúde e transporte, entre outros. Seria natural, portanto, que o agente promotor do programa habitacional fosse o responsável por esta gestão e eu coubesse a ele garantir a sustentabilidade econômica e social dos moradores.

\subsubsection{Exemplos de gestão pós-ocupação em edifícios de São Paulo}

Ao levar em conta todos os aspectos levantados até o momento, fica evidente que a gestão pós-ocupação (GPO) em edifícios reabilitados voltados para HIS é complexa e deve ser planejada desde o momento da formulação dos programas habitacionais.

Como a política de reabilitação de edifícios é bastante recente na cidade de São Paulo e os edifícios reabilitados entregues até 2005 serão objetos de estudo deste trabalho, a seguir serão apresentados outros exemplos de GPO, realizadas em edifícios novos, mas que também são voltados para HIS.

O conjunto habitacional Zezinho Magalhães, em Guarulhos, pode ser considerado um bom exemplo tanto de projeto arquitetônico como de apropriação por parte dos moradores, o que acaba favorecendo sua manutenção e conservação.

O projeto, proveniente da política de terras da Companhia Estadual de Casas Populares (CECAP), foi implantado em 1980 e abrange uma área de 180 hectares 
com 4.680 unidades habitacionais propostas somente em edifícios. A figura a seguir (Figura 3.2) ilustra a implantação do conjunto:

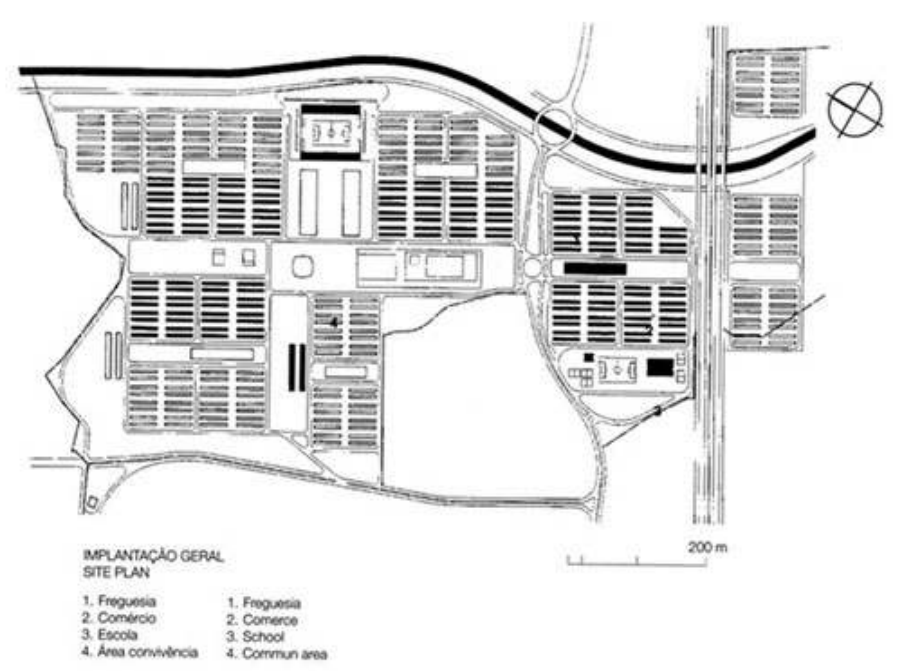

Figura 3.2 Implantação geral do conjunto habitacional Zezinho Magalhães.

Fonte: http://www.saplei.eesc.usp.br (Acesso em 14/03/2008)

Seu entorno era ocupado por loteamentos populares privados, baseados em uma estrutura tradicional de urbanização, com definições claras de lotes, quadras, ruas etc. Sua forma de implantação está próxima da solução adotada por Lúcio Costa no plano de Brasília, ou seja, baseada nas superquadras ${ }^{37}$, gerando uma unidade de vizinhança a partir da gestão dos espaços coletivos (ZANDONADE, 2005).

O projeto propõe que cada agrupamento de oito blocos forme uma unidade de gestão condominial a partir de um acesso comum, conforme Figura 3.3. Estes agrupamentos, chamados de freguesias, se articulam em torno de outros espaços urbanos públicos de acesso geral do conjunto, providos de equipamentos urbanos, serviço e comércio (Figura 3.4). A adoção deste princípio introduz uma gradação na escala dos espaços. Neste sentido, a escala do conjunto geral, que pode ser

\footnotetext{
${ }^{37}$ Como previsto no artigo 16 do Relatório do Plano Piloto de Lúcio Costa (COSTA, 1957), as superquadras são entendidas como "(...)uma seqüência contínua de grandes quadras dispostas, em ordem dupla ou singela, de ambos os lados da faixa rodoviária, e emolduradas por uma larga cinta densamente arborizada, árvores de porte, prevalecendo em cada quadra determinada espécie vegetal, com chão gramado e uma cortina suplementar intermitente de arbustos e folhagens, a fim de resguardar melhor, qualquer que seja a posição do observador, o conteúdo das quadras, visto sempre num segundo plano e como que amortecido na paisagem. Disposição que apresenta a dupla vantagem de garantir a ordenação urbanística mesmo quando varie a densidade, categoria, padrão ou qualidade arquitetônica dos edifícios, e de oferecer aos moradores extensas faixas sombreadas para passeio e lazer, independentemente das áreas livres previstas no interior das próprias quadras." (COSTA, 1957)
} 
associada à dimensão de uma porção da cidade, passa a ser hierarquizada em outras menores, passando do público para o privado de maneira um pouco mais gradual (ZANDONADE, 2005).

Como neste período os programas não tinham um sistema de habitação por locação, a adoção de escalas menores de unidades urbanas propiciou a geração de uma gestão condominial destes locais. Isto gerou uma nova forma de apropriação do espaço urbano, o coletivo, onde a responsabilidade de manutenção e de uso estão atribuídos a determinados núcleos de vizinhança e condomínios (ZANDONADE, 2005).

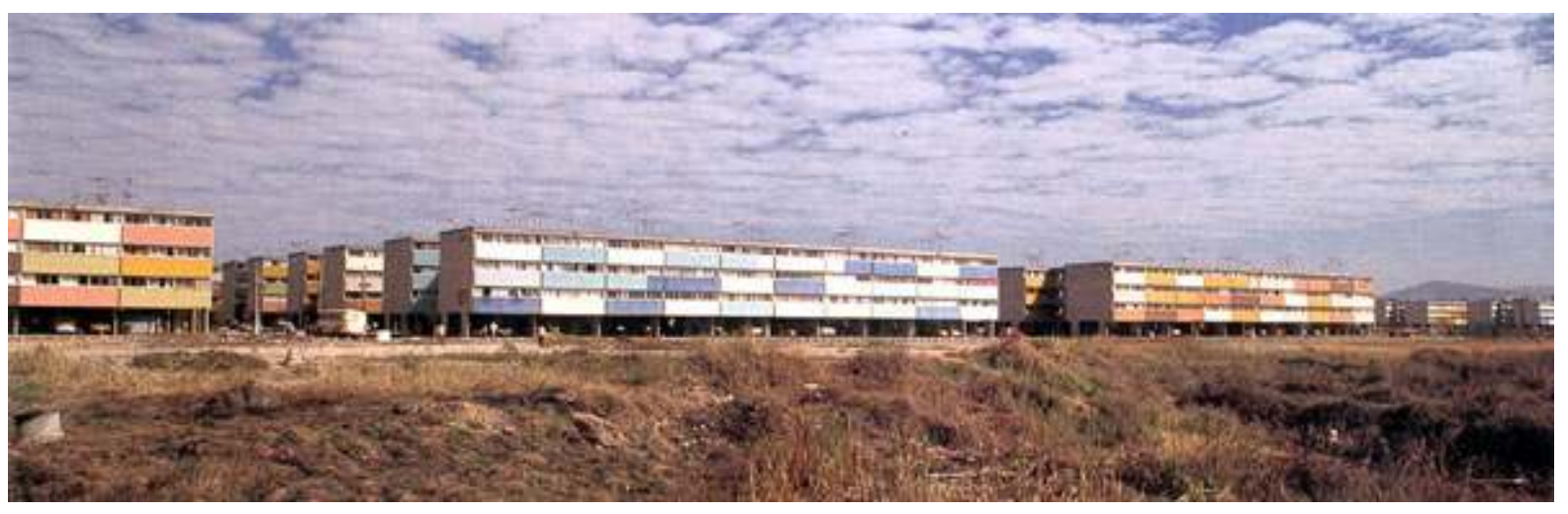

Figura 3.3 Vista do conjunto habitacional Zezinho Magalhães.

Fonte: http://www.saplei.eesc.usp.br (Acesso em 14/03/2008)

Como analisa Zandonade (2005) em sua pesquisa, no conjunto Zezinho Magalhães o espaço teve poucas alterações, como a limitação das áreas de cada condomínio. Na maioria dos casos, os espaços livres no nível térreo dos blocos coletivos continuam como o projeto original, as freguesias foram cercadas com gradis e seu acesso é controlado por uma portaria. A vegetação e a arborização das áreas ajardinadas se mantêm em bom estado de conservação e o nível de conservação do conjunto em geral está elevado.

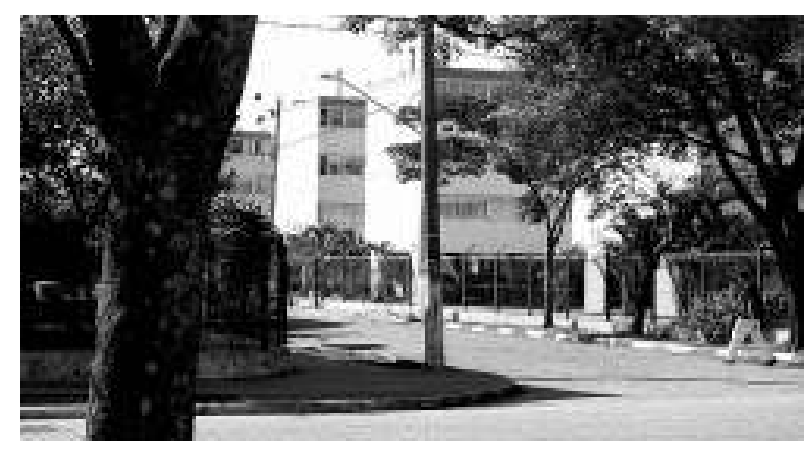

Figura 3.4 Imagem das freguesias do conjunto habitacional Zezinho Magalhães. Fonte: http://www.saplei.eesc.usp.br (Acesso em 14/03/2008) 
Um ponto importante a ser levado em consideração neste projeto é a faixa de renda da população que efetivamente ocupou as unidades. Destinado inicialmente à população de baixa renda, o conjunto gradativamente passou a ser valorizado e ocupado por camadas de renda superiores, fato que é comum de ser citado como sendo o responsável pela conservação dos espaços (ZANDONADE, 2005).

Outro exemplo positivo de apropriação de edifício por parte dos moradores a ser destacado é o Empreendimento Santa Cecília A (Pirineus) construído pela CDHU dentro das propostas do Programa de Atuação em Cortiços $^{38}$ (PAC), entregue em 2003 (Foto 3.1)

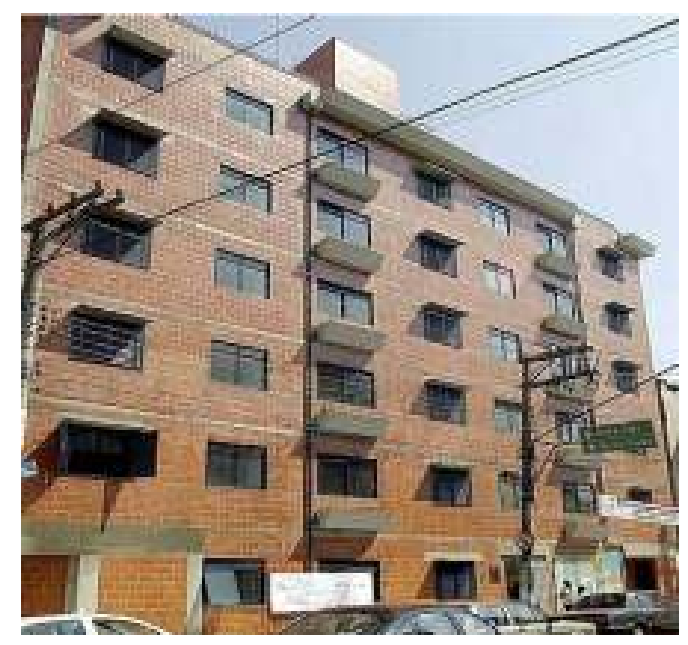

Foto 3.1 Edifício Pirineus no ano em que foi entregue aos moradores. Fonte: Barros, 2004.

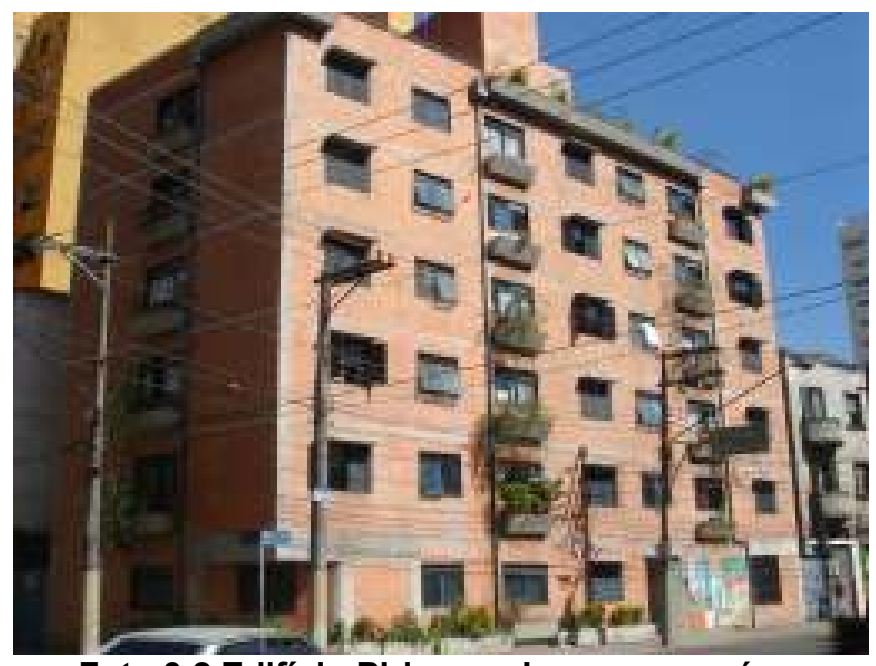

Foto 3.2 Edifício Pirineus cinco anos após a entrega ${ }^{39}$.

A edificação está localizada na área central da cidade, no bairro de Santa Cecília, em um terreno que abrigava um conjunto de três casarões construídos no início do século 20 utilizados como típicos cortiços da região central. Com o remembramento dos lotes e um projeto diferenciado para o terreno, que tem uma área de $332 \mathrm{~m}^{2}$, foi construída uma nova edificação de 28 unidades habitacionais auxiliada pela atualização de legislação de uso do solo, adensando seu potencial construtivo (BARROS, 2004).

\footnotetext{
${ }^{38}$ O Programa de Atuação em Cortiços tem por objetivo melhorar a qualidade de vida das famílias de baixa renda moradoras de cortiços localizados em áreas centrais degradadas, induzindo a reabilitação de imóveis e a reciclagem de antigos edifícios, promovendo a otimização da infraestrutura urbana, dos serviços e equipamentos já instalados através dos altos investimentos públicos realizados no passado, e amenizando a diferenciação entre os segmentos sociais plenamente atendidos e a parcela cujas condições historicamente não permitem o acesso pleno a esses benefícios (CDHU, 2000).

${ }^{39}$ As fotos que não tiverem sua fonte referenciada, foram feitas pela autora do trabalho no período da elaboração da pesquisa.
} 
A população moradora faz parte de movimento social organizado denominado Associação Comunitária dos Trabalhadores Sem-Teto na Luta 2 de Abril "Primeira Vitória" que reivindica moradia em área central e é filiada ao Fórum dos Cortiços e Sem-Tetos de São Paulo.

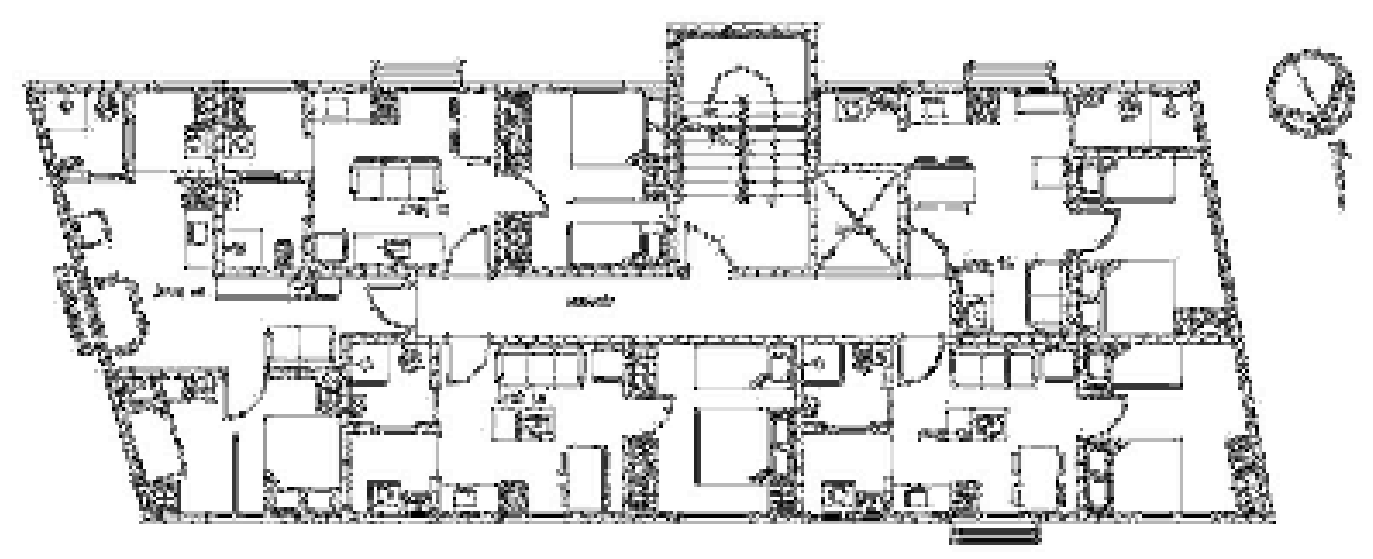

Figura 3.5 Planta do pavimento tipo do edifício Santa Cecília A. Fonte: BARROS, 2004.

O grande diferencial deste edifício foi a participação dos futuros moradores durante toda a concepção do projeto. Houve grande entrosamento entre a assessoria técnica, autora do projeto, e os moradores, que discutiram desde aspectos técnicos até funcionais (Figura 3.5). Este entrosamento gerou uma sensação de "projeto exclusivo" para cada família, não por serem plantas diferentes, mas sim, por todos terem sido ouvidos durante a concepção (BARROS, 2004).
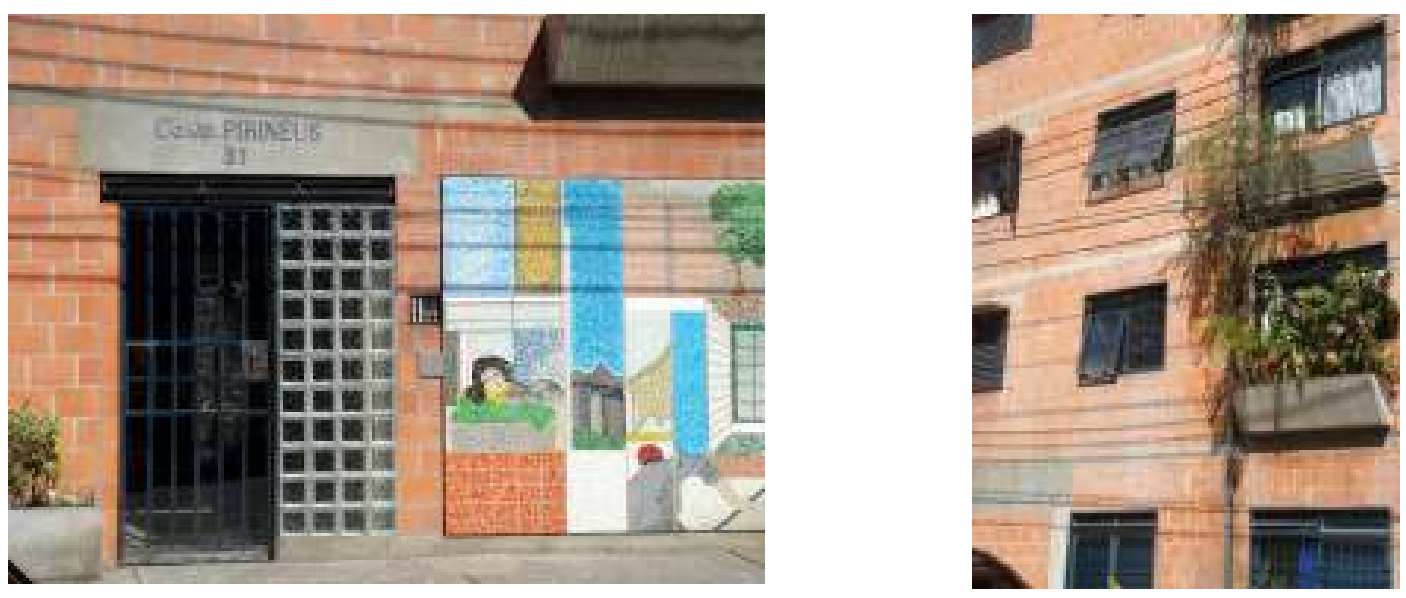

Foto 3.3 Detalhes da conservação da fachada do edifício Pirineus.

O fato de a população pertencer a um movimento social organizado apresentou um diferencial na forma de apreender o espaço e de compartilhar as áreas comuns da edificação. Os conflitos de convivência foram minimizados e a 
inadimplência é muito baixa. A baixa rotatividade de moradores também é um ponto importante a ser levantado, pois demonstra que a população está conseguindo se manter no edifício (BARROS, 2004).

Em contrapartida aos dois edifícios apresentados, alguns exemplos da ineficiência na gestão pós-ocupação em edifícios habitacionais podem ser identificados em São Paulo.

Dois conjuntos habitacionais recém entregues pela Prefeitura de São Paulo, Olaria e Parque do Gato, que fazem parte do programa de locação social ${ }^{40}$, já apresentam problemas na GPO.

O programa de locação social trabalhou com uma concepção integrada de moradia visando à localização adequada, facilidade de transporte, lazer, trabalho, geração de renda, educação e à participação dos moradores na gestão do projeto. Um trabalho social extenso foi previsto a fim de atender a todos, principalmente homens e mulheres desempregados, crianças e jovens (PMSP, 2005).

Nota-se, entretanto, um agravamento das condições sociais, de tensão e de desorganização, bem como indícios de aumento da violência nessas comunidades. A gestão condominial foi inicialmente feita por administradoras terceirizadas, mas logo foi interrompida, ficando a cargo da Companhia Metropolitana de Habitação (COHAB) a administração dos condomínios. Esta mudança na administração interrompeu a proposta de trabalho de gestão e passou a ser algo mais burocrático, por ser provisório (PMSP, 2005).

O Conjunto Residencial Olaria, entregue em agosto de 2004, possui 137 apartamentos distribuídos em três blocos, sendo 92 apartamentos de dois dormitórios, 24 de um dormitório e 21 quitinetes (Figura 3.6). O empreendimento conta com três elevadores, instalados de forma a propiciar o uso pelos moradores dos três blocos, já que os corredores são interligados. Possui salão de festas, churrasqueira, áreas verdes e de lazer, além de salas com uso comercial inicialmente proposto, mas que até agora estão fechadas sem definição quanto ao

\footnotetext{
${ }^{40}$ O programa de locação social da Prefeitura de São Paulo faz parte do programa Morar no Centro e foi criado pela resolução 23 do Conselho do Fundo Municipal de Habitação. O programa tem como objetivo ampliar as formas de acesso à moradia para a população de baixa renda que não tem possibilidade de participar dos programas de financiamento para aquisição de imóveis ou que, por suas características, não tenha interesse na aquisição de unidades habitacionais já construídas. Tem por objetivo também garantir o acesso à moradia independentemente do acesso à propriedade, prática bastante utilizada em países como França e Itália(PMSP, 2005).
} 
vínculo de sua utilização. Todos os apartamentos com finais 5 e 6 do bloco 1 são adaptados a idosos e deficientes (Fábrica Urbana, 2004).
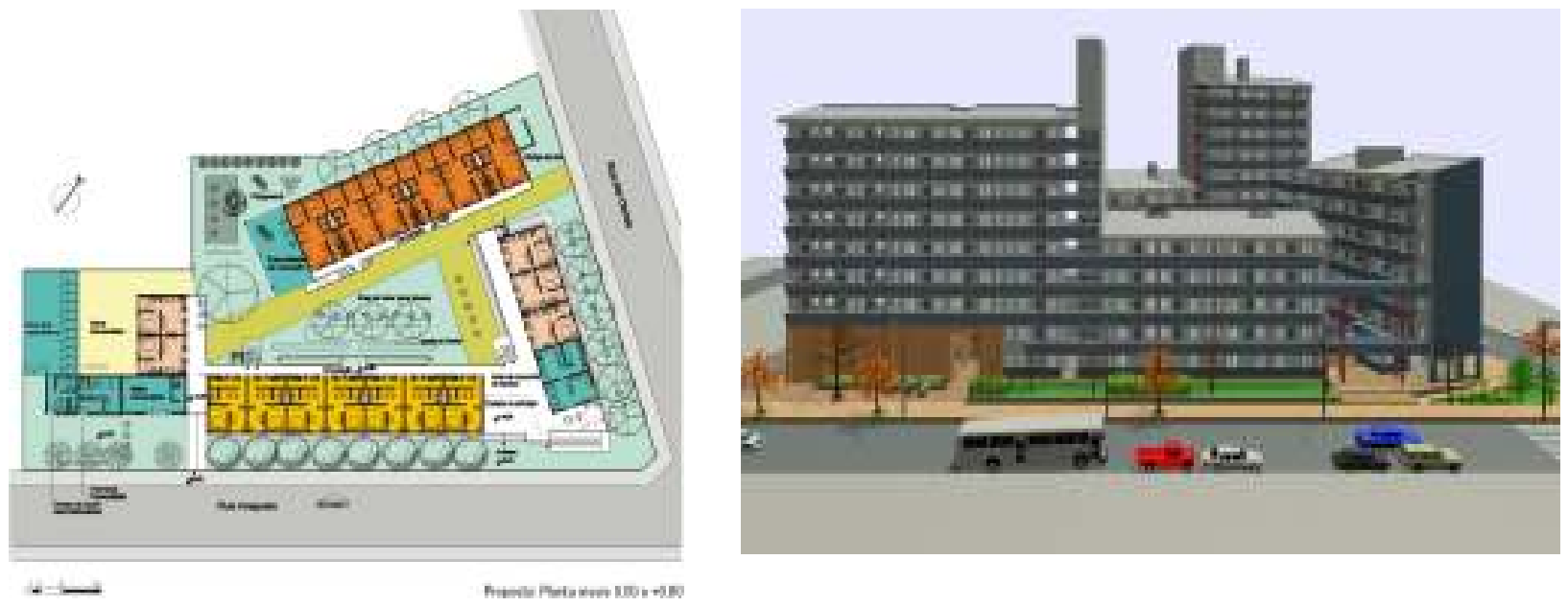

Figura 3.6 Imagens da implantação e elevação do projeto Olaria. Fonte: Assessoria técnica Fábrica Urbana, 2004.

Segundo estudo feito pelo Centro Gaspar Garcia de Direitos Humanos (Fórum Centro Vivo, 2006), nestes quatro anos o conjunto já enfrenta graves problemas, identificados abaixo:

-Abastecimento de água: inadimplência com a Sabesp, (a administradora deixou de repassar valores pagos pelos condôminos devido à inadimplência de alguns condôminos), falta de orientação para leitura de relógios por unidade habitacional, vazamentos;

-Abastecimento de energia elétrica: inadimplência de contas individuais e coletivas, falta de apoio da $\mathrm{COHAB}$ na negociação e parcelamento junto à Eletropaulo, risco de corte de energia elétrica nas áreas coletivas, o que pode gerar desligamento da bomba d'água, problemas nos relógios de energia (desvio de energia ou outra irregularidade na medição e cobrança), que oneram as contas de consumo individual;

-Elevadores: sem manutenção e quebrados há mais de dez meses, mesmo considerando o objetivo do programa em proporcionar atendimento habitacional às pessoas com necessidades especiais (deficientes e idosos);

-Riscos: falta de pára-raios, falta de manutenção de luz elétrica nas escadarias e corredores, problemas de manutenção na bomba d'água, rachaduras nos beirais; 
-Administração do condomínio: Falta de prestação de contas para os condôminos por parte da administração anterior; falta de prestação de contas para os condôminos pela COHAB e falta da discussão sobre alternativas de administração do condomínio.

- Trabalho Social: não está sendo realizado conforme as diretrizes do Programa Locação Social.
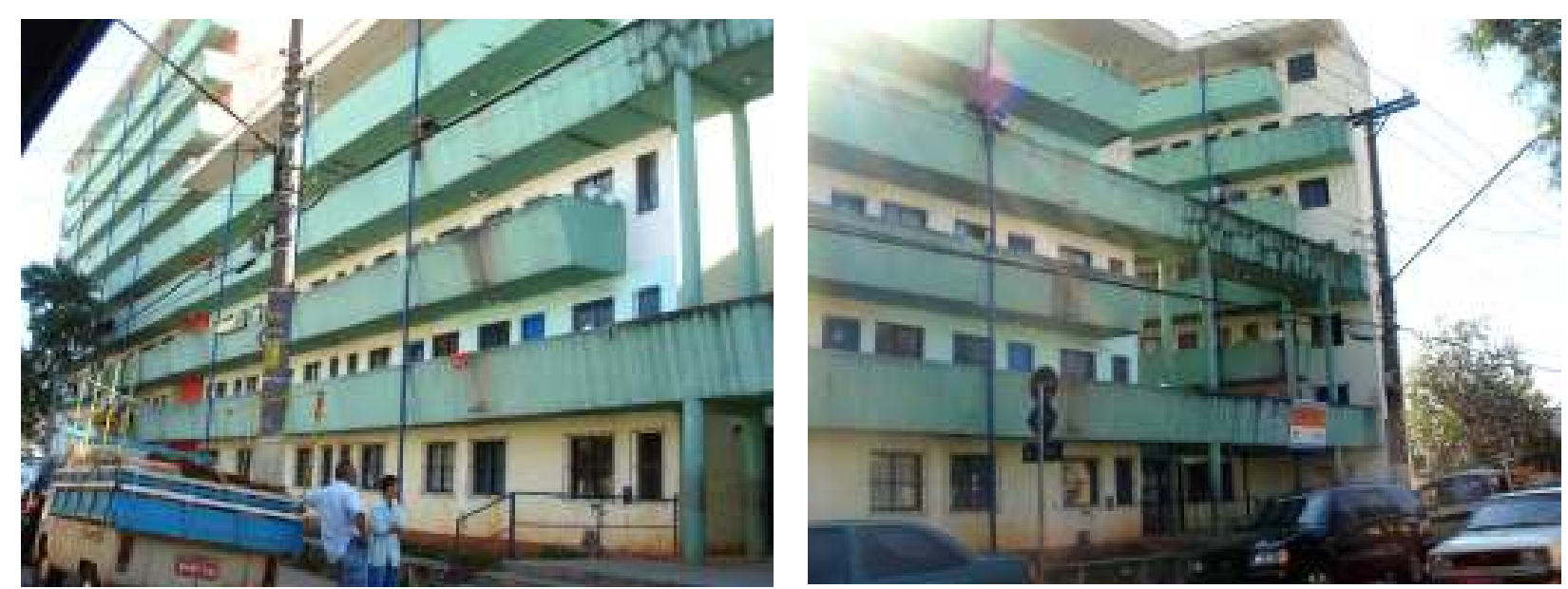

Foto 3.4 Imagens do conjunto Olaria após quatro anos de ocupação.

O trabalho técnico social previsto para o edifício não foi elaborado, o que possivelmente agrava cada vez mais os problemas anteriormente apontados e aumenta a insegurança dos moradores em um conjunto recém ocupado (Foto 3.4).

Já o residencial Parque do Gato, segundo conjunto recém entregue pela PMSP, foi implantado ao lado da extinta Favela do Gato para atender prioritariamente às famílias residentes no local. O projeto foi iniciado logo após um incêndio que destruiu dezenas de barracos e chamou a atenção para a situação de risco existente na área: além do perigo de inundações, a favela era ameaçada por um gasoduto que passa pela faixa lindeira (PMSP, 2005).

Um levantamento com os moradores da favela objetivando o atendimento habitacional por parte de Secretaria de Habitação (SEHAB) constatou que as famílias possuíam em média uma renda mensal de até três salários mínimos, o que direcionou a proposta do programa para locação social (PMSP, 2005).

O conjunto possui 486 unidades habitacionais distribuídas em nove blocos, quatro condomínios cercados por gradis, sendo 243 apartamentos de um dormitório, 162 apartamentos de dois dormitórios e 81 quitinetes (Figura 3.7). Dos 
equipamentos previstos no projeto, foi implantado somente o Centro de Educação Infantil Sonho de Criança ${ }^{41}$ (PMSP, 2005).
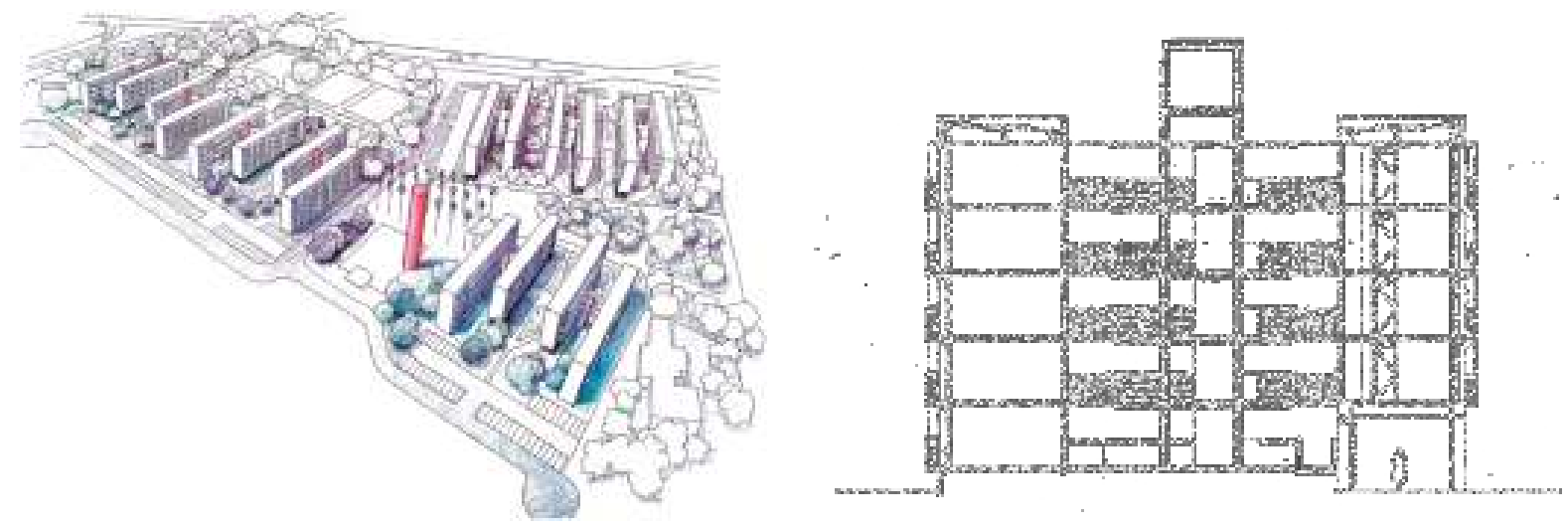

Figura 3.7 Imagens ilustrativas do projeto arquitetônico do Residencial Parque do Gato: perspectiva e corte.

Fonte:PRISMA, 2007

O projeto adotou o processo construtivo de alvenaria estrutural com blocos de concreto em todas as unidades, inclusive nos edifícios dos equipamentos complementares, como creche e salões de convivência (PRISMA, 2007).

De acordo com os idealizadores do projeto “(...) a proposta do parque procurou fugir da má tradição de entregar conjuntos habitacionais sem a urbanização dos espaços públicos ou os equipamentos básicos para a vivência comunitária. Além disso, os prédios têm requintes raros em outros projetos para baixa renda. Exemplo são as portas-balcão dos apartamentos de dois dormitórios, que trazem um enorme ganho de salubridade e qualidade arquitetônica, embora encareçam um pouco a obra", observa Wagner Germano, um dos autores do projeto (PRISMA, 2007).

Entretanto, nestes quatro anos de gestão pós-ocupação, graves problemas no conjunto são evidenciados. Desde problemas sociais relacionados à situação ocupacional irregular das unidades, até problemas construtivos do edifício (Foto 3.5 e Foto 3.6). A própria SEHAB estima que 31\% dos 486 apartamentos estão ocupados irregularmente e $65 \%$ dos ocupantes são inadimplentes (Flosi, 2006).

\footnotetext{
${ }^{41}$ Faz parte da proposta de intervenção do Complexo a implantação de um posto policial, um parque com equipamentos esportivos para uso do bairro e da cidade, um núcleo administrativo para o Centro Desportivo Municipal e um sistema viário público.
} 


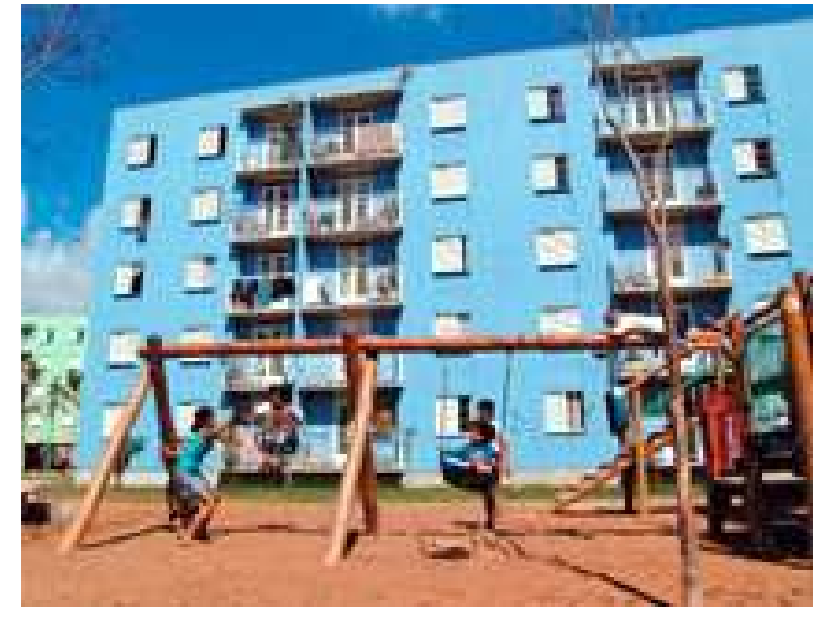

Foto 3.5 Residencial Parque do Gato no ano de entrega aos moradores. Fonte: PRISMA, 2006.

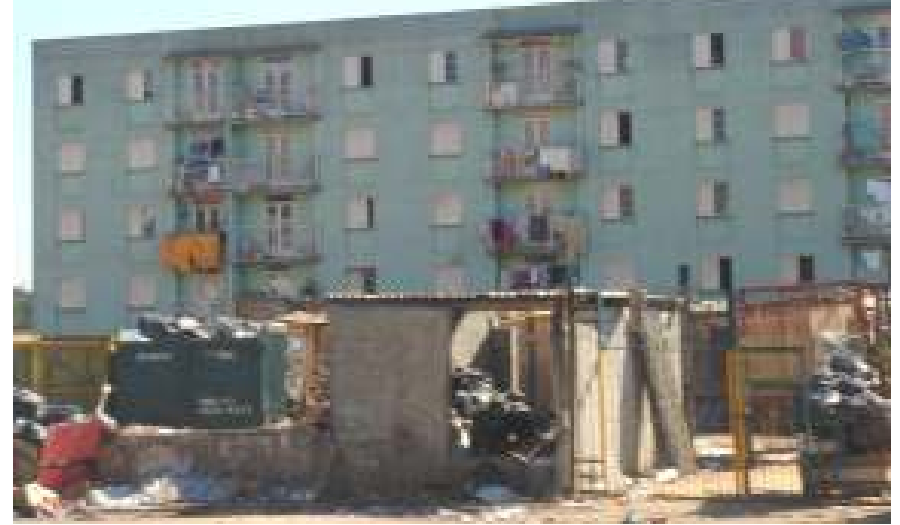

Foto 3.6 Residencial Parque do Gato quatro anos após a entrega.

Em visita realizada ao conjunto em julho de 2008 (Foto 3.7), constatou-se que a degradação do edifício é visível mesmo à distância. Além dos objetos nas fachadas, a deterioração dos edifícios e das áreas comuns é impactante.

Em levantamento feito pela PMSP, atualmente são encontrados no Parque do Gato problemas como a ausência de zeladoria e portaria, gerando insegurança aos moradores; ausência de equipamentos de segurança, como extintores e mangueiras de incêndio; problemas construtivos e de conservação dos blocos; e a atuação de grupos ilícitos organizados (PMSP, 2005).

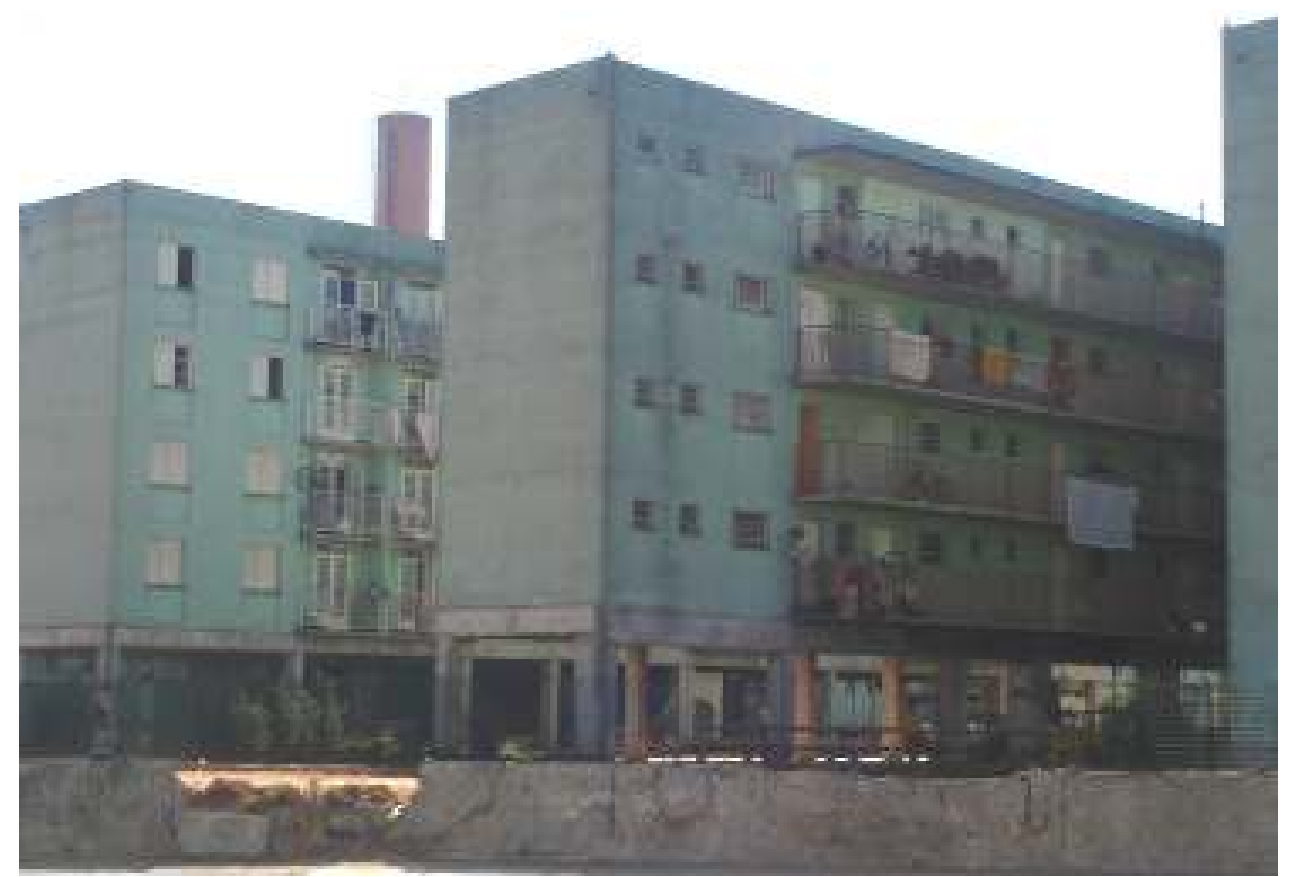

Foto 3.7 Imagem do Residencial Parque do Gato quatro anos após a entrega. 
Enfim, os exemplos negativos mostram que, além de uma possível falta de compromisso demonstrada pela população residente em cuidar dos edifícios, a ausência de acompanhamento por parte do poder público é característica comum aos dois conjuntos habitacionais. Em visitas realizadas nos dois residenciais, ficou claro o sentimento de abandono e desvalorização que existe por parte dos moradores, devido provavelmente aos inúmeros problemas existentes em somente quatro anos de gestão. Além disso, o aspecto visual dos dois conjuntos também favorece este sentimento, prejudicando o objetivo inicial do programa habitacional.

Já os exemplos positivos de gestão apresentados indicam claramente situações em que a população moradora se apropriou efetivamente do local de moradia, zelando tanto pelas unidades habitacionais quanto pelas áreas comuns, 0 que resultou de uma gestão pós-ocupação eficiente.

\subsection{Experiência internacional}

A experiência internacional na gestão de edifícios habitacionais e bairros sociais é bastante ampla, principalmente em países europeus que, após a Segunda Guerra Mundial, precisaram adotar políticas de habitação em massa para suprir o déficit habitacional causado pelas destruições (EASTAWAY, 2007). Estas políticas passaram a ser adotadas pelo poder público, que necessitava atender a uma demanda urgente de alojamentos ${ }^{42}$.

O método utilizado para suprir este grande déficit foi a arquitetura em série, feita a partir da industrialização e da produção em massa, padronizada através dos grandes blocos de conjuntos habitacionais construídos nas periferias das cidades, o que fez surgir os chamados bairros sociais.

Com o passar do tempo, muitos conjuntos passaram a ter problemas graves de degradação física e social. Os governos dos países iniciaram então políticas de reabilitação destes edifícios e bairros a fim de reduzir o mal estar social e aumentar a qualidade de vida destas pessoas (DELERA, 2005).

\footnotetext{
${ }^{42}$ É neste período que países centrais na economia ocidental capitalista tomam para si a responsabilidade no provimento de habitação para o trabalhador, dentro da política de "bem estar social" (ZANDONADE, 2005).
} 
As intervenções foram e ainda são feitas por meio de instrumentos fiscais e urbanísticos nos quais a política habitacional não é mais vista como um elemento separado, mas como algo associado a outras políticas mais amplas e aliadas ao tema do desenvolvimento sustentável. A sustentabilidade ambiental, social e econômica dos bairros passa a ser o tema central destas intervenções, em conjunto com a acessibilidade dos idosos e pessoas com deficiência (DELERA, 2005).

A experiência portuguesa em gestão pós-ocupação de edifícios habitacionais populares será descrita a seguir, a fim de direcionar e exemplificar algumas das possibilidades de realização desta gestão no Brasil, garantindo a sustentabilidade social, econômica e ambiental de seus moradores e edifícios.

\subsubsection{A experiência portuguesa em gestão pós-ocupação de edifícios}

A experiência portuguesa na gestão de edifícios voltados para habitação social é fortemente caracterizada por uma grande política de gestão urbana, norteada pela existência de Gabinetes Técnicos Locais (GTL), que têm como objetivo servirem de estruturas de apoio ao bairro nas intervenções necessárias em termos técnicos e administrativos, e ao mesmo tempo por um corpo operacional que atua como extensão do governo local (PADOVANI, 2005).

Cada bairro possui seu gabinete, que torna-se acessível para a população local e possibilita uma gestão mais próxima. A equipe, formada por técnicos em diversas áreas (arquitetura, administração, economia, engenharia, assistência social, geografia, sociologia, psicologia, história, entre outras), fica em contato constante com a população, chegando muitas vezes a ter o sentimento de pertencer ao bairro, o que faz com que passe a ser defensora desta comunidade junto ao governo (LOPES, 2006). "O Gabinete é um motor a puxar e tem que ser assim. Uma administração longínqua, não consegue fazer isso, tem que ser gente que está envolvida no processo ali, localmente" (LOPES, 2006).

Porém, a experiência da cidade de Guimarães chama a atenção pela riqueza do trabalho de administração e gerenciamento da população e de suas necessidades após a aquisição da unidade habitacional. 
Desde 1999, a cidade de Guimarães adotou como uma de suas prioridades políticas a habitação digna para todos os cidadãos do município. Entretanto, o conceito de habitação empregado não se resume apenas ao fornecimento de unidades habitacionais, mas sim a um conceito mais abrangente, no qual moradia também quer dizer acesso à cidade e àquilo que representa a vida no espaço urbano, como emprego, educação, formação, cultura, transporte, saúde, informação, lazer, etc.

Para isso, a Câmara Municipal de Guimarães criou a Coordenação de Âmbito Social e Financeiro das Habitações Sociais de Guimarães (CASFIG), uma empresa pública, sem fins lucrativos, de âmbito municipal, cujo objetivo principal é gerir os vários empreendimentos sociais construídos na cidade, além de estudar e propor medidas para a resolução dos problemas habitacionais das famílias cuja situação não permita recorrer ao mercado particular (CASFIG, 2008).

De acordo com os técnicos da empresa, a situação de pobreza e de más condições de habitação pode agravar o modo como uma família é afetada por determinados problemas, a ponto de provocar rupturas relacionais que em condições "normais" não existiriam (CASFIG, 2008)..

Segundo a filosofia da CASFIG, as políticas de habitação devem ser integradas à educação, à formação, ao emprego, à saúde, à cultura, à segurança social, e aos serviços sociais como forma de abordagem mais eficaz, tanto na luta contra a pobreza e a exclusão social, como na contribuição para a inclusão social (CASFIG, 2008).

Sendo assim, compete à CASFIG, “(...) gerir os vários empreendimentos de habitação social construídos e a serem entregues com total isenção e rigor, associando a qualidade de vida da população residente à boa conservação do patrimônio" (CASFIG, 2008)

Atualmente, a CASFIG gere aproximadamente 800 unidades habitacionais em um total de 34 empreendimentos sociais, entre edifícios novos e reabilitações.

Em levantamento feito pela empresa, verificou-se que a maioria da população residente nos empreendimentos pertencia a famílias particularmente vulneráveis a fenômenos de exclusão social e que requeriam uma atuação global e conjunta no sentido de efetivar uma integração social positiva e evitar a guetização e degradação destes conjuntos (CASFIG, 2008). 
Assim, a diversidade de problemas encontrados nesta população, como a elevada taxa de desemprego, formação escolar insuficiente, dependência tóxica, limitação de informação, violência doméstica, entre outros, justifica as inúmeras áreas e ações de intervenção, que são desenvolvidas com o apoio de diversos parceiros através de um esquema de ação integrada em várias vertentes - saúde, educação,formação profissional, ação social etc (CASFIG, 2008).

Deste modo, o acompanhamento às famílias residentes tem sido desenvolvido levando em conta os seguintes objetivos:

- integrar os indivíduos nos empreendimentos e estes na cidade, com valorização dos espaços e dignificação dos contextos sociais;

- sensibilizar e formar a população;

- dotar os residentes de competências que os auxiliem na adaptação às novas condições de vida e à adequada organização e apropriação dos espaços;

- garantir o cumprimento da regulamentação da utilização dos espaços comuns;

- eliminar os fatores de conflito entre vizinhos e colaborar na inclusão de indivíduos afetados por doença física ou mental, desestruturação familiar e violência doméstica;

- promover ações mobilizadoras de atitudes de estima e conservação do espaço habitado, motivando os moradores para a correta utilização das unidades habitacionais e áreas comuns;

- promover a participação plena da cidadania de cada indivíduo;

- combater a solidão e o isolamento, com especial incidência na população idosa;

- promover a sociabilidade e o fortalecimento dos laços comunitários de relação entre a população do próprio empreendimento e entre esta e o bairro;

- reforçar os sentimentos de pertencimento e das capacidades individuais;

- promover a cultura e o sucesso escolar;

- promover os laços de solidariedade e vizinhança.

Atualmente a empresa é formada por uma equipe multidisciplinar, que conta com sociólogos, assistentes sociais, arquitetos, engenheiros civis, educadores, psicólogos, administradores, contadores e advogados.

$O$ atendimento às famílias pode ser feito de três maneiras: 
1) Realojamento: é oferecido às famílias que não se adaptaram à modalidade habitacional em que estavam inseridas e que precisam ser realojadas.

$\mathrm{O}$ trabalho desenvolve-se em três fases: Pré-realojamento, Realojamento e Pós-Realojamento.

O Pré-realojamento é a fase que antecede a entrega das chaves da respectiva unidade e é de extrema importância, uma vez que irá refletir o modo pelo qual cada integrante da família irá se apropriar da habitação. São realizadas diversas reuniões em horários alternativos, para que todas as famílias possam estar presentes sem que para isso precisem se ausentar de suas atividades profissionais. As reuniões são realizadas em pequenos grupos, respeitando o empreendimento em que irão ser realojados, e têm a seguinte ordem de trabalho:

- Apresentação de todos os funcionários da CASFIG;

- Apresentação da localização geográfica do empreendimento;

- Apresentação dos futuros vizinhos;

- Conhecimento da nova casa;

- Conhecimento das casas por tipologia;

- Apresentação do regulamento do empreendimento;

- Apresentação e assinatura do contrato de arrendamento;

- Confirmação da localização de cada família;

- Procedimentos a serem tomados para a requisição de água, luz e gás;

- Informação geral de entidades/ serviços de utilidade pública da nova área de residência;

- Preparação para a cerimônia de entrega das chaves da unidade;

- Apresentação do plano de realojamento;

- Esclarecimentos técnicos gerais.

A segunda fase, o Realojamento, ocorre no período de mudança dos novos moradores, em que a equipe da CASFIG acompanha a família na transição para a nova casa, dando especial atenção às famílias com menos instrução. Este acompanhamento também inclui o apoio logístico para o transporte de móveis e pertences.

A equipe técnica orienta os moradores em relação à utilização de equipamentos da nova casa através da distribuição de um manual que contém 
regras de utilização do espaço, além de informações e conselhos relacionados à conservação dos ambientes construídos, de modo a garantir qualidade de vida a todas as famílias residentes.

Após o realojamento efetivo de todos os moradores, a equipe da CASFIG inicia o pós-realojamento através de um conjunto de intervenções de caráter social, uma vez que estas famílias apresentam desequilíbrios familiares provocados essencialmente por problemas de dependência de álcool, tóxicos, violência doméstica e abandono escolar.

2) Ação Social: $O$ trabalho social tem como objetivo a integração social, profissional e educativa de todas as famílias residentes no parque habitacional que se encontra sob sua gestão.

Assim, uma vez que são muitos e diversificados os problemas que afetam as famílias, são também diversas as dimensões em que a intervenção dos Serviços de Ação Social da empresa abrange. Efetivamente, são focados alguns setores estratégicos como a educação, a saúde e a formação profissional.

A insalubridade das condições de habitabilidade, de que a maioria é oriunda, encontra-se intimamente ligada a fatores como o fraco nível de instrução, o desempenho de trabalhos de baixa qualificação e o usufruto de parcos rendimentos, o que potencializa comportamentos como dependências tóxicas, alcoolismo, distúrbios mentais, estados de ansiedade, limitação de informação/ formação, violência doméstica, dificuldades de integração no mundo do trabalho, elevada taxa de desemprego, dificuldades de aprendizagem, falta de cultura escolar, analfabetismo etc.

Trata-se, portanto, de efetivar uma intervenção integrada que dinamize iniciativas, modifique formas de pensar e desbloqueie barreiras ao desenvolvimento, o que não é mais que um processo cuja finalidade é satisfazer necessidades sociais.

Deste modo, a tônica dominante do trabalho desenvolvido pelos Serviços de Ação Social da CASFIG materializa-se numa intervenção em várias frentes, uma vez que conferir a estas famílias uma habitação munida de infra-estruturas dignas de proporcionar a qualidade de vida a que todos têm direito é, por si só, manifestamente insuficiente. 
No acompanhamento dos familiares em geral e de cada indivíduo em particular, a CASFIG privilegia sempre o trabalho articulado com as várias instituições existentes, estabelecendo acordos, protocolos ou outros meios de colaboração.

3) Educação social: A Educação social é um dos vetores fundamentais da intervenção social da CASFIG. As ações desenvolvidas visam dotar e potencializar os residentes de instrumentos valorativos de competências pessoais de modo a contribuir para a integração social das famílias residentes. O trabalho desenvolvido nesta área ocorre por meio de ações de caráter educativo, cultural, recreativo e social, tais como:

a) Curso de Formação: Trata-se de uma formação especialmente dirigida aos residentes dos empreendimentos que se encontram sob a gestão da empresa, através de cursos com módulos de desenvolvimento pessoal, social e cidadania, economia doméstica, cuidados primários de saúde, higiene pessoal e habitacional, entre outros.

b) Educação e Formação Parental: Trata-se de efetuar uma aposta nas famílias, porque a empresa acredita que as mesmas, apoiadas, criarão condições para educar melhor os seus filhos, contribuindo assim para o desenvolvimento de crianças e jovens emocionalmente mais equilibrados, integrados socialmente e, principalmente, que gostam de si e da vida.

Deste modo, nesta área de intervenção, a CASFIG busca prestar informação aos pais no sentido de facilitar a compreensão dos problemas escolares dos filhos, ajudando-os a resolvê-los; explorar os motivos/ causas do insucesso, absentismo e abandono escolar; reforçar o papel preponderante que a escola tem na formação das crianças e adolescentes, e que se repercute no seu desenvolvimento pessoal e futuro profissional; prevenir o insucesso escolar e abandono precoce da escola, promovendo uma maior proximidade entre a instituição de ensino e a família através de uma boa comunicação, entre outros fatores.

Esta aposta nas práticas parentais, de caráter curativo e preventivo, é efetuada através de ações de sensibilização/ formação dirigidas aos pais por técnicos especializados, com distribuição de folhetos informativos, e pelo 
acompanhamento técnico regular e personalizado às famílias, com particular incidência nas mais disfuncionais.

c) Ações de sensibilização e esclarecimento: A empresa organiza reuniões com o objetivo de informar/ formar a população residente nas habitações sociais. Entre os assuntos abordados estão o planejamento familiar, além de tópicos como dependência tóxica, direitos do consumidor, entre outros. Além disso são organizados grupos de jovens, programas de férias, passeios etc.

Nesta linha de orientação, a empresa sempre procura trabalhar em parceria com estabelecimentos de ensino, centros de saúde e hospitais, institutos de emprego e formação profissional, entre outros, a fim de garantir esta rede de proteção social aos moradores.

Após este panorama geral nos trabalhos executados pela CASFIG, é possível concluir que a política que norteia as ações da empresa entende que dotar as pessoas de uma habitação digna não é, por si só, solução de todos os seus problemas, especificamente os da exclusão social. O mero ato da entrega de uma habitação a uma família, sem qualquer preparação, pode até aumentar os focos de exclusão social, pelo desenraizamento desta população, pelo desconhecimento da utilização dos espaços e pela falta de preparação para estabelecer relações de vizinhança.

Há, portanto, um extenso trabalho desenvolvido paralelamente à provisão habitacional, que é fundamentado principalmente no acompanhamento social das famílias nos mais diversos níveis e desenvolvido por equipes multidisciplinares, de modo a dotar a família de informação e formação para resolver seus problemas de vivência em comunidade. 


\section{Edifícios reabilitados em São Paulo voltados para HIS}

Nesta parte do trabalho serão apresentados cinco empreendimentos reabilitados voltados para Habitação de Interesse Social (HIS) no centro de São Paulo selecionados como objeto de análise. Todos fazem parte do Programa de Arrendamento Residencial (PAR), da Caixa Econômica Federal (CEF), em parceria com a Prefeitura de São Paulo (PMSP).

Os cinco empreendimentos estudados, apresentados na figura abaixo (Figura 4.1), são: Fernão Salles e Riskallah Jorge, na Sé; Olga Benário, no Belém; Maria Paula e Labor, na República.

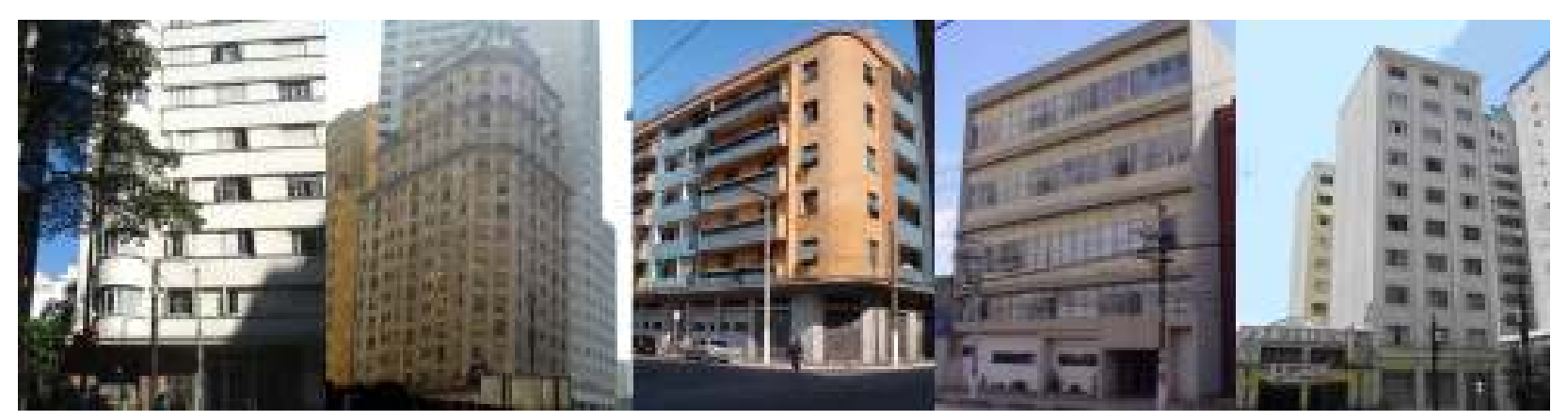

Figura 4.1 Imagem dos empreendimentos estudados. Da esquerda para direita: Maria Paula, Riskallah Jorge, Fernão Salles, Olga Benário e Labor.

Foram estabelecidos alguns critérios que amparam a escolha destes empreendimentos. Além da condição básica de serem edifícios vazios no centro de São Paulo que passaram por um processo de reabilitação, foram selecionados aqueles em que a gestão pós-ocupação tivesse no mínimo dois anos.

A sistematização elaborada para organização dos dados de cada empreendimento foi:

- Dados gerais e o histórico do empreendimento;

- Aspectos sociais da gestão pós-ocupação;

- Aspectos econômicos da gestão pós-ocupação;

- Aspectos físico-construtivos da gestão pós-ocupação;

- Aspectos arquitetônicos e urbanísticos da gestão pós-ocupação.

O primeiro parâmetro procura contextualizar o empreendimento através de alguns dados gerais e seu histórico. São apresentadas informações como a 
localização, o uso inicial do edifício, o número de unidades ofertadas após a reabilitação, as tipologias das unidades habitacionais, a origem do edifício e o projeto de reabilitação.

A seguir são apresentados os chamados aspectos sociais do empreendimento relacionados com a gestão pós-ocupação. Dados como relacionamento entre moradores e com a administradora, tipo de gestão empregada, taxas condominiais etc.

Na seqüência, estão expostos os aspectos econômicos da gestão pósocupação. Este item procura identificar problemas relacionados a taxas de financiamento, condomínio, fundo de reserva, inadimplência, entre outros.

Em seguida são identificados os aspectos físico-construtivos da edificação por meio de problemas construtivos, sistemas que não funcionam corretamente, manutenção, manual do proprietário etc.

Por fim, são apresentados os aspectos arquitetônicos e urbanísticos do empreendimento, em que são elencadas as características do projeto proposto, necessidades dos usuários, localização, acessibilidade, entre outros.

As informações dos empreendimentos e dos moradores utilizadas foram obtidas através de entrevistas realizadas durante a pesquisa. As conversas seguiram, dependendo do interlocutor - moradores, técnicos sociais, construtores pontos específicos e não foram dirigidas por um roteiro fixo de perguntas, permeando sempre assuntos relacionados à gestão condominial e suas principais qualidades e defeitos, relação de vizinhança no prédio, o momento da mudança para o edifício, problemas construtivos, taxas condominiais etc. Cabe ressaltar que devido a questões internas entre os moradores e a CEF, alguns dados não puderam ser obtidos. 


\subsection{Edifício Maria Paula}

\subsubsection{Dados gerais e histórico do empreendimento}

O edifício Maria Paula, entregue em 2003, localiza-se no distrito da República na cidade de São Paulo-SP. A Tabela 4.1 apresenta os dados gerais do empreendimento, e a Figura 4.2 indica a localização na cidade.

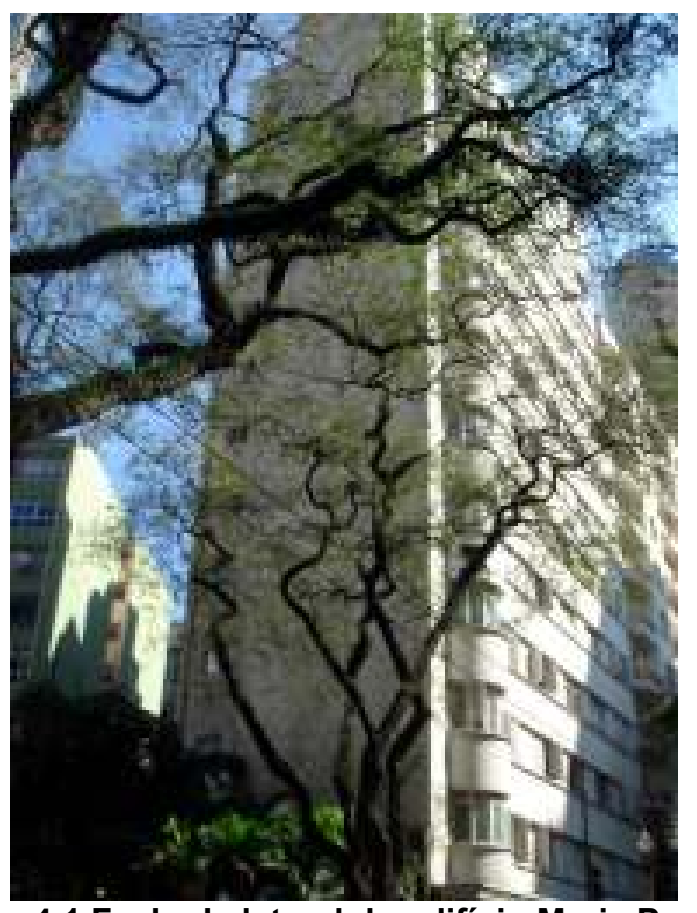

Foto 4.1 Fachada lateral do edifício Maria Paula.

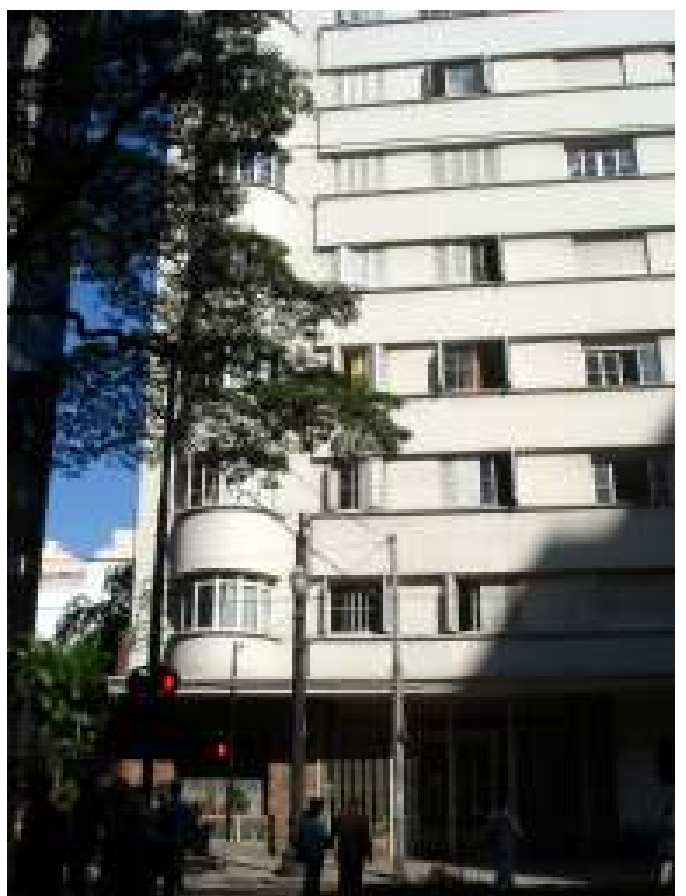

Foto 4.2 Fachada do edifício Maria Paula.

Tabela 4.1 Dados gerais do edifício Maria Paula

\begin{tabular}{|c|c|}
\hline Localização: & Rua Dona Maria Paula, 171 - República. São Paulo/SP. \\
\hline Programa: & PAR-Reforma \\
\hline Uso Inicial: & Habitação de alto padrão \\
\hline Número de unidades propostas: & $75 \mathrm{UH}$ \\
\hline Início da obra de reabilitação: & Maio/ 2001 \\
\hline Data de entrega do edifício reabilitado: & Dezembro/ 2003 \\
\hline \multirow{4}{*}{ Tipologias: } & $26,43 \mathrm{~m}^{2}$ - Ambiente multiuso e banheiro (48 unidades) \\
\hline & $26,43 m^{2}$ - Ambiente multiuso e banheiro para deficientes ( 02 unidades) \\
\hline & $38,16 \mathrm{~m}^{2}$ - Sala, copa, cozinha, dormitório e banheiro (24 unidades) \\
\hline & $50,00 \mathrm{~m}^{2}$ - Sala, copa, cozinha, 2 dormitórios e banheiro (01 unidade) \\
\hline \multirow[t]{2}{*}{ Equipamentos coletivos propostos: } & Lavanderia coletiva \\
\hline & Salão de festas/ reuniões \\
\hline Custo médio da unidade: & $\mathrm{R} \$ 24.974,36^{*}$ \\
\hline Tipo de gestão condominial: & Terceirizada \\
\hline Valor da parcela do finaciamento: & 220 ** \\
\hline Valor da taxa de condomínio: & $\begin{array}{l}\mathrm{R} \$ 114 \text { (sendo } \mathrm{R} \$ 94 \text { taxa padrão + } \mathrm{R} \$ 10 \text { fundo de reforma + } \mathrm{R} \$ 10 \text { fundo } \\
\text { de melhorias) ** }\end{array}$ \\
\hline
\end{tabular}

* Fonte: MALERONKA/ 2005

** Dados fornecidos pelos moradores 
O edifício Maria Paula foi projetado na década de 40 pelo escritório Técnico A. B. Pimentel para habitações de alto padrão. Em seus 13 pavimentos abrigava 25 apartamentos tipo, e no térreo e subsolo possuía equipamentos coletivos, comércio, além de dois elevadores e escada para o acesso às residências (SALCEDO, 2005). Com o passar dos anos, o edifício foi sendo abandonado por seus moradores, que precisavam, por exemplo, de garagens para seus automóveis.

Mesmo após anos de ociosidade, o único proprietário não tinha interesse em vender seu imóvel para programas de moradia popular. Nos anos 90, o edifício vazio chegou a passar por pequenas reformas para ser alugado na sua forma original de apartamentos de alto padrão. Porém, dada a estagnação do mercado imobiliário no centro de São Paulo e a pressão trazida pelos movimentos de moradia no centro, o proprietário decidiu vender o prédio para o Fundo de Arrendamento Residencial (FAR) da CEF (MALERONKA, 2005).
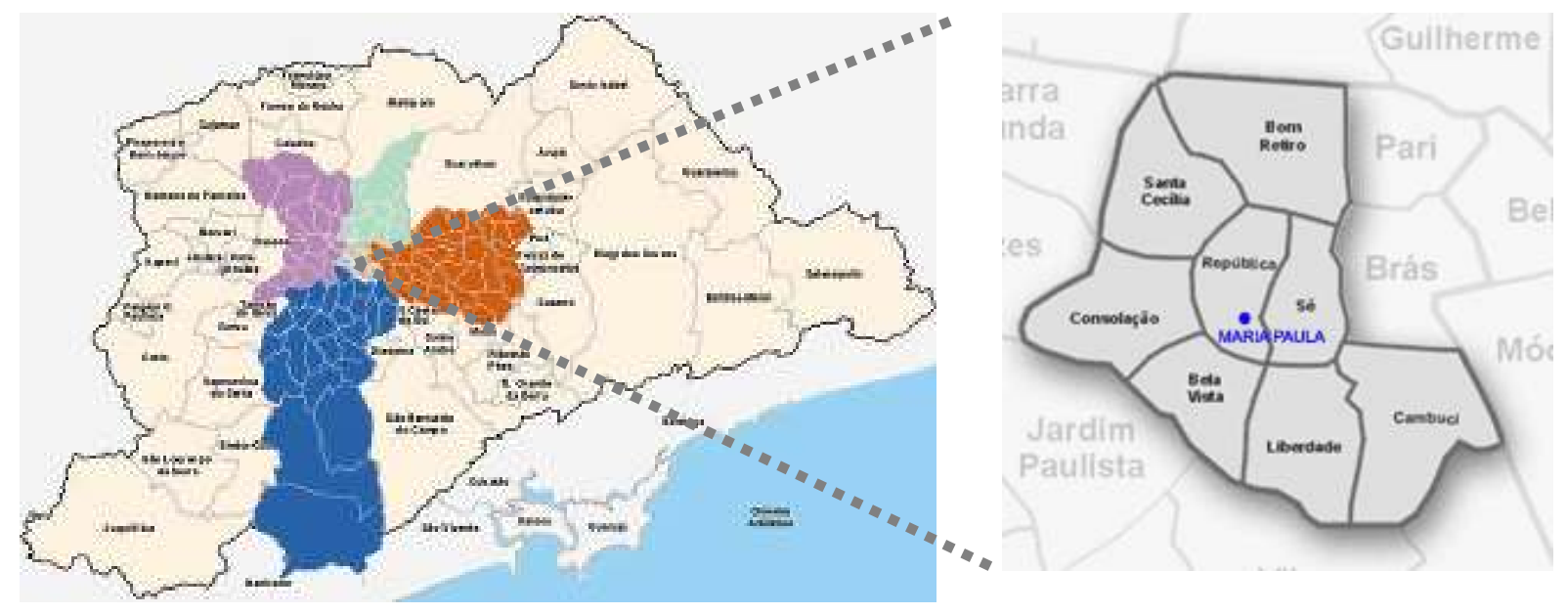

Figura 4.2 Localização da cidade de São Paulo e edifício Maria Paula.

O projeto de reabilitação foi realizado pela assessoria técnica Fábrica Urbana em parceria com o Fórum de Cortiços e Sem-teto de São Paulo, sendo a obra executada pela construtora 3RD Ltda, do Estado do Mato Grosso.

Após a reforma, o edifício passou a abrigar 75 unidades habitacionais com área média de $40 \mathrm{~m}^{2}$. A fachada foi praticamente mantida como no projeto original e somente algumas esquadrias foram trocadas por não estarem em boas condições (Figura 4.3). 

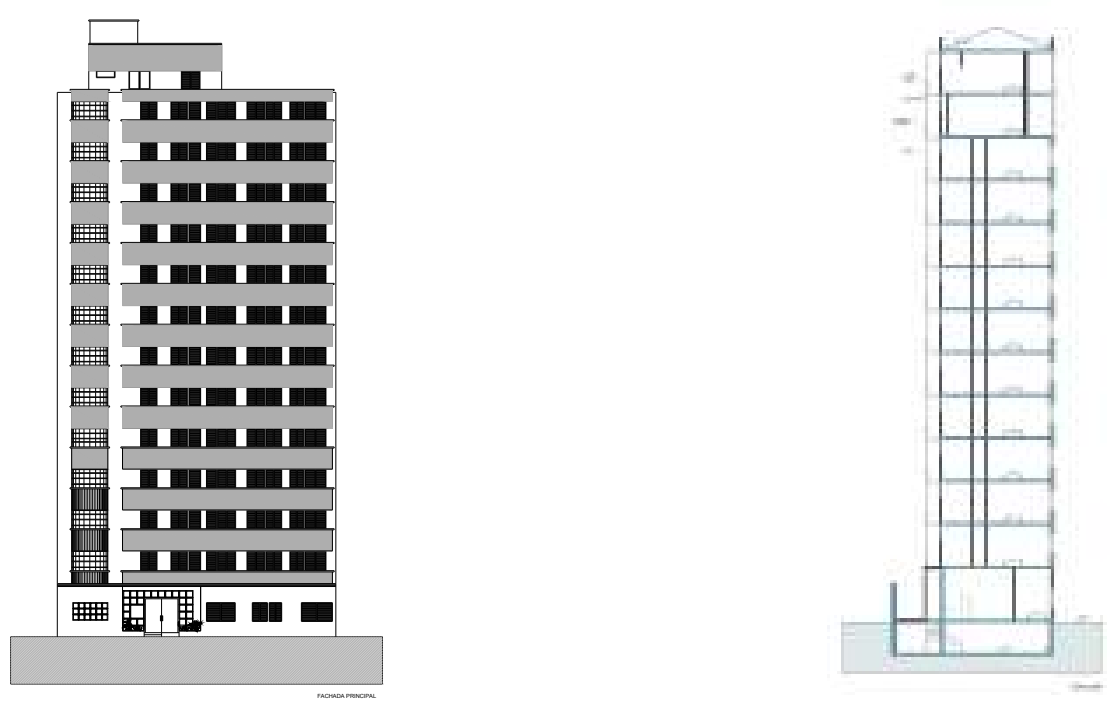

Figura 4.3 Elevação frontal e Cortes do edifício Maria Paula. Fonte: Assessoria Técnica Fábrica Urbana.

O subsolo passou a ter, além de reservatório de água, uma área de lazer destinada aos condôminos, que atualmente é utilizado como salão de festas. No pavimento térreo, foram propostos o hall de acesso com a portaria, dois elevadores e uma lavanderia coletiva (Figura 4.4).

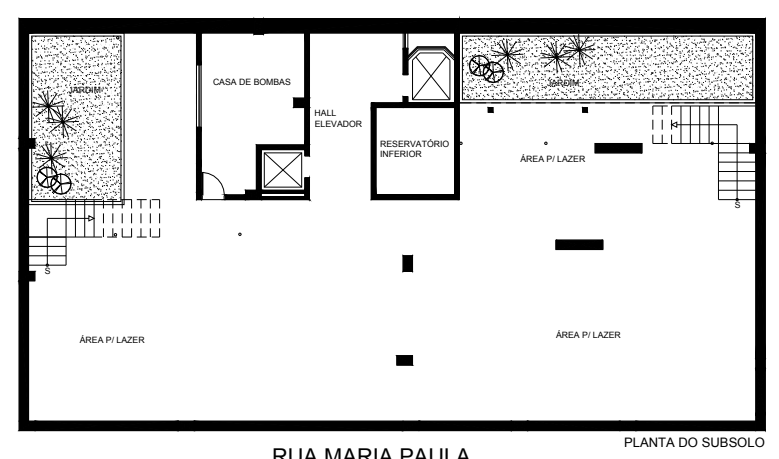

RUA MARIA PAULA

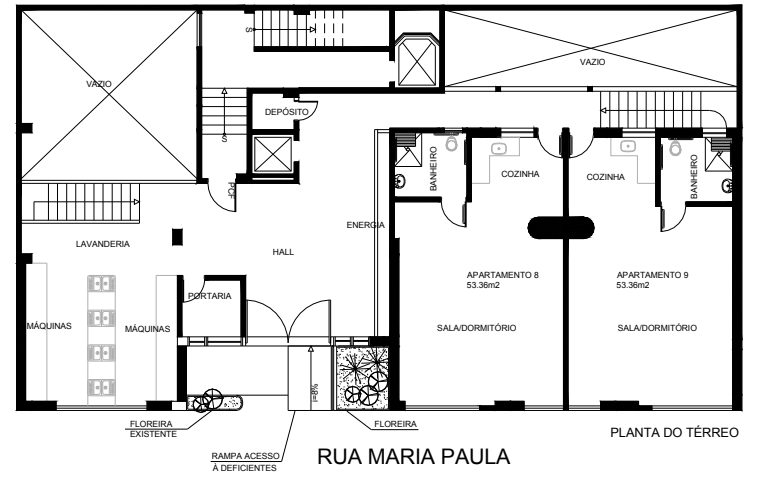

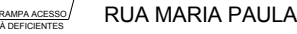

Figura 4.4 Planta do subsolo e do pavimento térreo do edifício Maria Paula. Fonte: Assessoria Técnica Fábrica Urbana.

Os doze pavimento-tipo abrigam seis unidades habitacionais de 26 e $38 \mathrm{~m}^{2}$ (Figura 4.5). No $13^{\circ}$ pavimento foi projetada uma unidade de $50 \mathrm{~m}^{2}$ com dois dormitórios e um banheiro. 


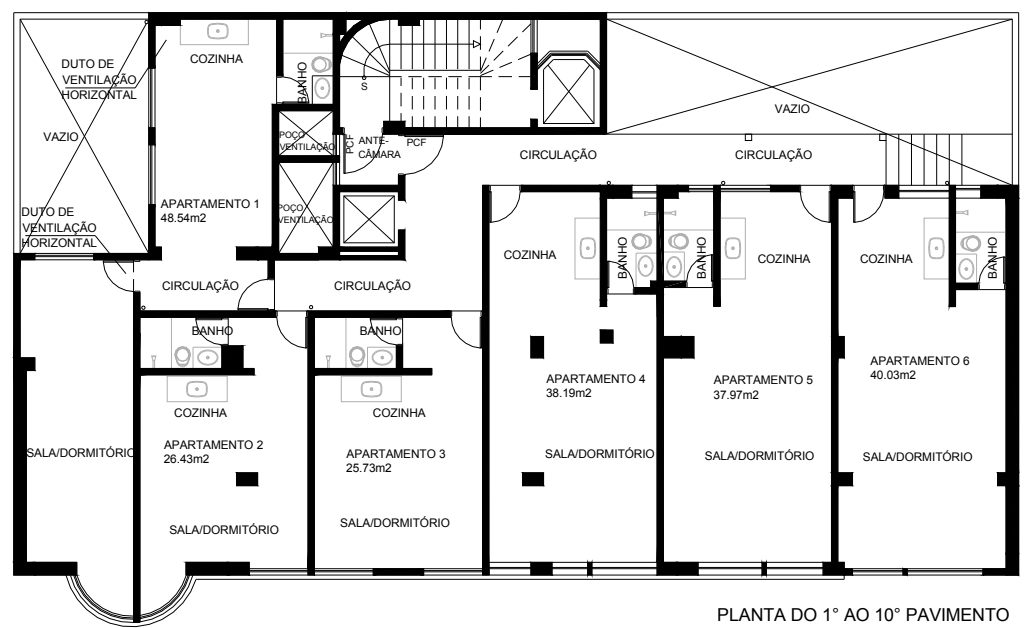

Figura 4.5 Planta do pavimento tipo do edifício Maria Paula.. Fonte: Assessoria Técnica Fábrica Urbana.

A alvenaria de vedação original de tijolos foi mantida. As novas divisórias internas foram executadas em blocos de concreto celular (Fábrica Urbana, 2004) assentados com argamassa de cimento, cal e areia. A estrutura de concreto armado existente foi mantida por encontrar-se em bom estado de conservação, assim como as características externas da fachada (Foto 4.3). As principais alterações ocorreram nas divisórias internas de cada pavimento para viabilizar a construção das 75 unidades habitacionais.

Grande parte das esquadrias foi removida, com exceção das esquadrias de formato arredondado, que foram restauradas. O método utilizado nas novas instalações prediais foi o tradicional de tubulações de PVC e elétrica embutida no forro. Conforme Foto 4.4, a edificação foi adaptada às normas de incêndio e reservação de água sem a necessidade de aumento do número de reservatórios, sendo suficientes os já existentes antes da reforma (REABILITA, 2007).

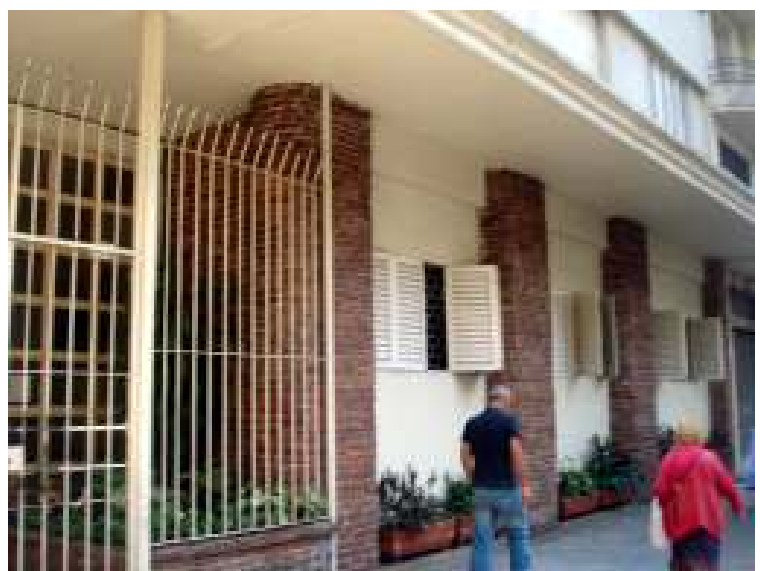

Foto 4.3 Entrada do edifício Maria Paula. Fonte: REABILITA, 2007.

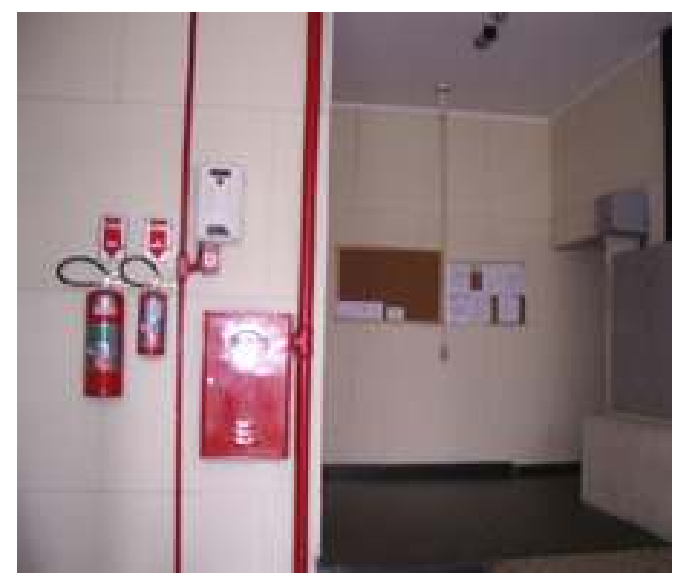

Foto 4.4 Novas instalações de segurança. 


\subsubsection{Aspectos sociais da Gestão Pós-Ocupação}

Devido a uma parceria entre a PMSP, CEF e movimentos de luta por moradia, os moradores contemplados com as unidades do edifício Maria Paula eram integrantes de um movimento chamado Fórum de Cortiços e foram indicados para fazer parte do programa como arrendatários das unidades ${ }^{43}$.

A obra de reabilitação foi entregue em dezembro de 2003 e os moradores mudaram-se no início de 2004. Logo após a ocupação, os arrendatários receberam a notícia de uma alta dívida de IPTU, além de uma segunda, relacionada ao sistema de portaria implantado pela construtora. Juntas, as dívidas somavam aproximadamente $\mathrm{R} \$ 50$ mil e deveriam ser pagas pelos próprios moradores.

As regras do programa de arrendamento exigem que a gestão condominial implantada no prédio seja terceirizada por uma administradora, que automaticamente torna-se o síndico do empreendimento, representando a CEF, o que ocorreu nos primeiros meses de ocupação. Porém, devido às altas taxas cobradas pela empresa e à existência das dívidas relacionadas ao edifício, os moradores reuniram-se e decidiram que a administradora iria fazer o serviço básico administrativo (emissão de boletos, controle de gastos gerais), enquanto que os serviços terceirizados (zeladoria, segurança, limpeza) seriam feitos pelos próprios moradores de acordo com um sistema de revezamento.

Ou seja, no início do pós-ocupação, a gestão condominial era mista, sendo que para alguns serviços era realizada a autogestão e para outros existia uma administradora terceirizada, buscando-se assim a diminuição dos gastos.

Após o pagamento das dívidas (aproximadamente dois anos depois), os moradores optaram pela administração terceirizada total, em que a empresa se responsabiliza por todos os serviços da gestão. Quando perguntados se gostariam de voltar para um sistema de autogestão, os moradores afirmam que não, pois as relações de vizinhança ficam muito estremecidas com este tipo de gestão. "Imagina você ter que ficar cobrando o pagamento de todo mundo todo mês? Não dá certo não. Você tem que fazer só isso na vida e aqui todo mundo trabalha. Vira maloca!" diz uma moradora.

\footnotetext{
${ }^{43}$ Após algum tempo, os moradores acabaram se desvinculando do movimento de moradia e atualmente não fazem parte de nenhum grupo organizado.
} 

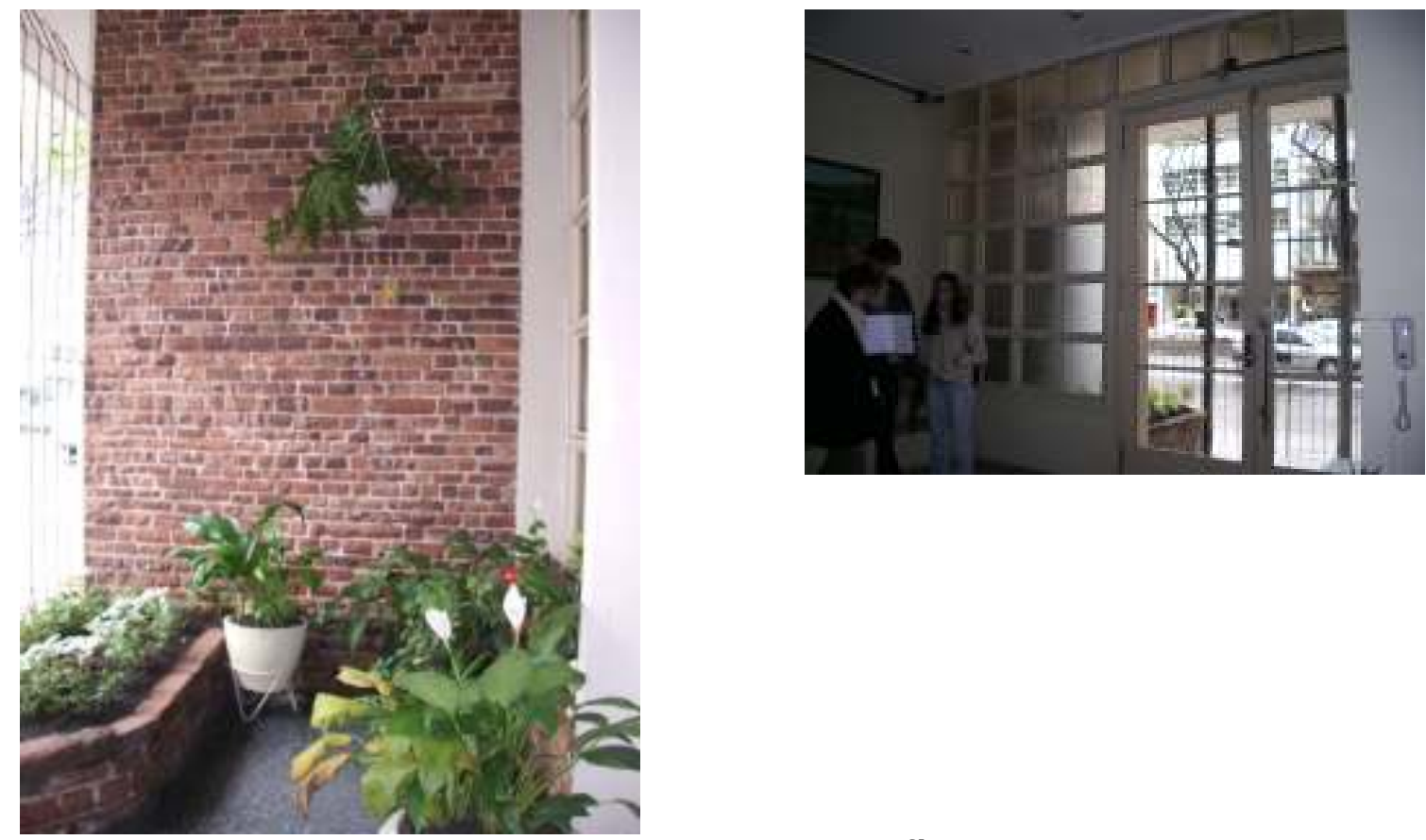

Foto 4.5 Imagens da entrada do edifício Maria Paula.

Fonte: REABILITA, 2007.

Também dentro das regras do PAR, após a entrada dos moradores no edifício, a CEF contrata um Trabalho Técnico Social (TTS), com o objetivo de integrar os moradores, além de esclarecer qualquer dúvida em relação ao programa ou aos papéis da administradora, da construtora e da CEF. No edifício Maria Paula este trabalho não foi realizado por opção das antigas lideranças do movimento de moradia, que alegavam que o grupo já era bastante solidificado e que 0 acompanhamento social não seria necessário.

Com relação aos problemas de relacionamento entre os moradores e usuários em geral, os arrendatários afirmaram que já haviam ocorrido alguns problemas, mas que foram resolvidos por eles mesmos. Um dos piores casos foi relacionado ao tráfico de drogas, em que um traficante mudou para uma unidade do edifício e utilizava o local para venda de drogas. Os moradores, mesmo recebendo uma série de ameaças, uniram-se e conseguiram expulsá-lo. $O$ apartamento ficou fechado por mais de um ano após o ocorrido, o que prejudicou os outros arrendatários, que passaram a ter os gastos condominiais maiores.

Outro episódio marcante ocorreu quando um morador, que não conseguiu arcar com as parcelas do arrendamento e as taxas condominiais, alugou a unidade para outra família e mudou-se do edifício. A nova família moradora também não pagou as taxas condominiais por três anos, prejudicando novamente os demais 
arrendatários com as dívidas. Na opinião dos moradores, a CEF deveria notificar o arrendatário após três meses de inadimplência caso a dívida não fosse quitada, a CEF deveria retirá-lo da unidade.

Ao ser perguntada se entraria novamente em um programa do PAR, uma moradora afirma que não e que preferiria uma carta de crédito pois "o PAR só dá certo se todos os moradores estiverem a fim de trabalhar. $E$ na verdade ninguém quer trabalhar, quer simplesmente morar. O PAR é inviável. Chega de par, vamos para o ímpar..."

Para os moradores, o fato de se conhecerem antes da mudança para o prédio através do movimento de moradia facilitou bastante o entrosamento entre eles e as relações de vizinhança. "Aqui é bom porque a maioria se conhece e quando não conhece é fácil de virar amigo", diz um morador. Apesar de não pertencerem mais a um movimento de luta por moradia, o edifício ainda possui uma liderança interna que procura melhorar as condições dos usuários e do edifício. "Os contatos com a CEF, administradora e construtora são quase diários e temos que centralizar em uma pessoa”, diz a moradora, que não se identifica como liderança, mas que acaba atuando como tal.

Já para a CEF, o fato de fazerem parte de um movimento organizado dificulta o trabalho, por ser um grupo fechado, com muito receio e restrições. "Quando já é um grupo formado, fica difícil de entrar e expor novas idéias, novas regras. Eles não ouvem, só vão ouvir o que a liderança disser. E muitas vezes as lideranças não querem nem conversa com os técnicos sociais por medo ou preconceito. É mais complicado do que trabalhar com um grupo novo, que está se conhecendo agora. Por outro lado, as relações de vizinhança dentro do condomínio são bem melhores porque eles se respeitam e devem satisfação aos líderes, o que intimida um pouco mais" (informação verbal) ${ }^{44}$.

Em pesquisa realizada pelo Instituto de Pesquisas Tecnológicas $(\text { IPT })^{45}$, Sanches (2008) aponta que a opinião dos moradores do edifício Maria Paula com relação ao tipo de gestão condominial empregada pelo programa é negativa. Outros

\footnotetext{
${ }^{44}$ Informação fornecida pela técnica social Célia Teixeira em entrevista realizada em 22 de junho 2007.

${ }^{45}$ Os dados coletados na pesquisa foram obtidos através de entrevistas nos edifícios estudados adotando o seguinte critério: empreendimentos com menos de 50 unidades $-15 \%$ de entrevistas (do número de unidades); entre 51 e $100-10 \%$ de entrevistas; maior que $101-5 \%$ de entrevistas.
} 
aspectos elencados na pesquisa, relacionados tanto ao condomínio quanto aos moradores, foram selecionados conforme tabela a seguir (Tabela 4.2):

Tabela 4.2 Dados gerais da gestão do edifício Maria Paula

\section{Edifício Maria Paula}

Avaliação da gestão condominial empregada:

\begin{tabular}{lc}
\hline Ótimo & $0 \%$ \\
\hline Bom & $50 \%$ \\
\hline Razoável & $0 \%$ \\
\hline Péssimo & $50 \%$ \\
\hline O que destaca de bom no condomínio? & \\
\hline Vizinhança & \\
\hline O que destaca de ruim no condomínio? & \\
\hline Conflitos & $88 \%$ \\
\hline Sua vida melhorou após a mudança para o edifício? & $13 \%$ \\
\hline Sim & \\
\hline Não & \\
\hline
\end{tabular}

Em qual aspecto considera que sua vida melhorou?

Auto-estima

Qual o tipo de trabalho que realiza atualmente?

\begin{tabular}{ll}
\hline Formal & $60 \%$ \\
\hline Informal & $40 \%$ \\
\hline Quantas pessoas moram no apartamento? &
\end{tabular}
3

Qual a renda familiar mensal?

\begin{tabular}{lc}
\hline Até 3 s.m. & $75 \%$ \\
\hline Até 6 s.m. & $25 \%$ \\
\hline Até 10 s.m. & $0 \%$ \\
\hline$>10$ s.m. & $0 \%$
\end{tabular}

Há quanto tempo mora no edifício?

\begin{tabular}{lc}
\hline Até 1 ano & $0 \%$ \\
\hline 1 a 2 anos & $0 \%$ \\
\hline 2 a 4 anos & $100 \%$ \\
\hline$>4$ anos & $0 \%$
\end{tabular}

Qual a forma de moradia anterior?

\begin{tabular}{lc}
\hline Aluguel & $20 \%$ \\
\hline Cortiço & $0 \%$ \\
\hline Favela & $0 \%$ \\
\hline Ocupação & $80 \%$ \\
\hline Outros & $0 \%$ \\
\hline
\end{tabular}

Fonte: SANCHES, 2008. 
Podemos destacar entre os dados coletados que $50 \%$ dos moradores entrevistados não estão satisfeitos com a gestão condominial empregada no prédio. Outro dado importante é o que indica que $75 \%$ dos entrevistados possuem renda média mensal de até três salários mínimos. Um aspecto que chama a atenção neste estudo é o de que $80 \%$ dos moradores vieram de ocupações junto aos movimentos de moradia e $100 \%$ dos entrevistados mora no mínimo há dois anos no prédio.

\subsubsection{Aspectos econômicos da Gestão Pós-Ocupação}

Em dezembro de 2003, a obra de reabilitação foi finalizada e os moradores começaram a mudar no início de 2004. Os gastos previstos para cada morador após a entrada seriam os referentes às parcelas do arrendamento e taxas condominiais, respectivamente, $\mathrm{R} \$ 220$ e 110, além das contas de água, luz e telefone.

Porém, logo após a mudança, os moradores afirmaram que receberam a noticia de que o prédio possuía duas grandes dívidas. A primeira, referente ao Imposto Predial e Territorial Urbano (IPTU) era de aproximadamente R \$ 28 mil. De acordo com os moradores, a CEF não entrou com o pedido de isenção do imposto, e o valor acumulado chegou a quase trinta mil reais. A representante da CEF, quando perguntada sobre o assunto, diz que o FAR está analisando o processo e que o valor será devolvido aos arrendatários futuramente.

A segunda dívida era relacionada ao equipamento da portaria $24 \mathrm{~h}$. De acordo com os moradores, a construtora e a CEF orçaram e contrataram um sistema de portaria que quando instalado não funcionava corretamente por não ser o mais adequado ao tipo do prédio, o que foi constado após a entrada dos moradores. A diferença de valores entre o sistema orçado e o realmente implantado foi de aproximadamente $\mathrm{R} \$ 28$ mil.

A solução adotada para os dois problemas foi um rateio entre os próprios moradores para pagar as dívidas, atualmente já quitadas. Mensalmente cada morador contribuiu com aproximadamente $\mathrm{R} \$ 30$ para que as dívidas não aumentassem. A representante da CEF, quando perguntada sobre o problema, diz que a CEF e a construtora também estão analisando o assunto para verificar se 0 valor será devolvido aos arrendatários futuramente. 
Quando perguntados sobre o maior gasto condominial, os moradores respondem sem hesitar: manutenção dos elevadores e telhados. Estes dois itens sempre necessitam de manutenção e acabam sendo pagos pelos condôminos. Quando um problema é detectado, os próprios moradores solicitam um orçamento do reparo, enviam para o síndico para aprovação (por ser um imóvel do PAR, a CEF é o síndico de todos os edifícios, mas acaba transferindo este direito para a administradora) e se autorizado, iniciam o serviço dividindo os custos entre eles. "Não entramos mais na discussão se somos nós ou a CEF ou a administradora que temos que arcar com os custos. Demora tanto para eles responderem, analisarem e pagarem que nós já decidimos que os valores ficam entre nós mesmos porque somos os mais interessados", diz uma moradora.

A taxa de água mensal fica entre $R \$ 1,4$ mil e $R \$ 1,2$ mil e tornou-se tarifa social somente após a iniciativa dos moradores, que entraram com um pedido na Sabesp após a ocupação do prédio. Por ser um empreendimento de habitação social, geralmente o próprio programa já prepara toda esta documentação para a entrada dos moradores, o que não aconteceu no edifício Maria Paula.

A taxa de condomínio atualmente é de $R \$ 114$, dos quais $R \$ 94$ correspondem à taxa da administradora terceirizada, $\mathrm{R} \$ 10$ para o fundo de reforma e R\$ 10 para o fundo de melhorias. Ou seja, os próprios moradores já prevêem esta necessidade de rateamento dos serviços de manutenção e reparos por meio destes fundos.

A inadimplência da taxa de condomínio é alta e atualmente $30 \%$ das famílias estão com as taxas condominiais atrasadas mais de três meses. A dívida do condomínio está em aproximadamente $\mathrm{R} \$ 7 \mathrm{mil}$, o que prejudica os demais arrendatários, que têm que arcar com estes custos. De acordo com uma moradora, "A renda média das famílias é muito diferente. Em um prédio como este, os gastos são muito grandes e somente alguns podem pagar. Os outros quase não conseguem pagar o arrendamento, que dirá o condomínio. E quem se prejudica é quem paga tudo em dia, porque tem que pagar as contas dos outros".

A renda média entre os condôminos é de quatro salários mínimos, 0 equivalente a $\mathrm{R} \$ 1,7$ mil. Os gastos mensais fixos com o apartamento são de aproximadamente R\$ 400 entre arrendamento, condomínio, água e luz sendo equivalentes a $1 / 4$ da renda média familiar. 
Em 2009 o prédio fará cinco anos e os moradores poderão quitar as parcelas do arrendamento para adquirir a residência. A maioria dos moradores, quando perguntados se irão optar por permanecer no edifício, afirmam que sim, mesmo com todas as dificuldades encontradas.

\subsubsection{Aspectos físico-construtivos da Gestão Pós-Ocupação}

No edifício Maria Paula, até hoje, quase cinco anos após a ocupação, os moradores ainda não receberam nenhum manual de uso edifício, nem as plantas das unidades, o que dificulta qualquer tipo de intervenção na edificação.

De acordo com os moradores, a qualidade técnica da reforma é muito baixa e desde o momento da mudança já eram encontrados problemas. No apartamento do último andar, por exemplo, no dia da entrega da unidade, os moradores perceberam que o forro de gesso do teto havia caído. Chamaram a construtora, que encaminhou um engenheiro para analisar o problema. Como depois de algum tempo nada havia sido feito, os próprios moradores resolveram fazer um orçamento do reparo no forro de gesso e acabaram arcando com os custos.

Outro problema grave são os elevadores. Existem dois elevadores no prédio que foram reformados, sendo que um deles possui porta pantográfica. Com alguns meses de uso, a base e as paredes do elevador com porta pantográfica cederam e o mesmo teve que ser interditado para reforma. Outro incidente com os elevadores ocorreu no início da ocupação, quando o funcionamento do equipamento alterava diretamente as instalações elétricas das áreas comuns, fazendo com que a iluminação dos corredores sofresse interferências.

A porta de entrada do prédio também possui alguns problemas, como emperrar, o que bloqueia a entrada dos usuários. De acordo com os moradores, já foi encaminhada uma solicitação de alteração da porta para a CEF, que até a data deste levantamento não entrou em contato.

Outro exemplo de problema construtivo ocorreu quando em um dos apartamentos a janela caiu e o morador não conseguiu instalá-la novamente. De acordo com os usuários, foram feitos relatórios com fotos dos problemas 
construtivos das unidades, mas até a data deste levantamento nada foi realizado e todos os reparos ficam a cargo dos moradores.

Quando os arrendatários percebem algum problema no prédio, entram em contato com a CEF, que se compromete a encaminhar um engenheiro da Gerência de Filial de Apoio ao Desenvolvimento Urbano (GIDUR), ou da Gerência de Alienação de Bens e Imóveis (GILIE). De acordo com os moradores, "o engenheiro vem, tira fotos, faz um relatório, mas depois disso nada acontece".

Conforme gráfico a seguir (Gráfico 4.1), de acordo com levantamento ${ }^{46}$ feito pelo Projeto Reabilita (2007) com base nos dados da CEF, a deficiência mais freqüente no Edifício Maria Paula está nas esquadrias, sendo que $28 \%$ dos problemas referem-se ao mau funcionamento das janelas. Em seguida, nota-se um grande número de problemas no item hidráulica, onde o maior índice está no sistema de coleta de esgoto e nas prumadas de águas pluviais, principalmente na paralela a um dos elevadores. O revestimento apresenta-se deficiente principalmente nas alvenarias externas, onde o maior problema é a infiltração. Há também questões relevantes de acabamentos, pinturas e tacos soltos. Outro problema com grande número de ocorrências é o piso, o qual indica um desnivelamento, principalmente no banheiro, causando empoçamento na área destinada ao box e nas áreas de circulação.

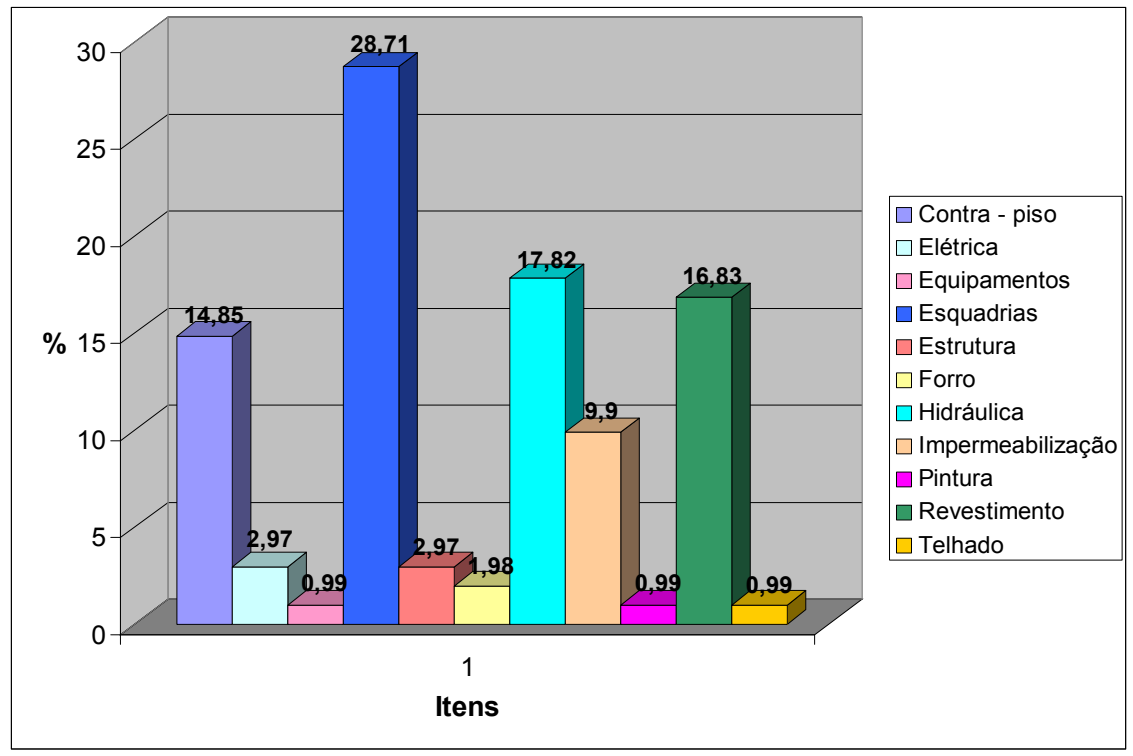

Gráfico 4.1 Porcentagem de problemas por itens construtivos nas unidades e áreas comuns do edifício Maria Paula.

Fonte: REABILITA, 2007.

\footnotetext{
${ }^{46}$ Os levantamentos foram realizados utilizando dados fornecidos pela CEF. Estes dados são referentes às reclamações feitas pelos moradores no período entre 2004 e 2006.
} 


\subsubsection{Aspectos arquitetônicos e urbanísticos da Gestão Pós-Ocupação}

Conforme Figura 4.6, em função das fachadas e aberturas externas já serem definidas, o projeto do edifício Maria Paula indica uma opção na solução por espaços conjugados e integrados (muitas vezes, as atividades de sala, dormitório, cozinha e lavanderia estão em um mesmo espaço, só sendo alterados pisos e acabamentos nas alvenarias).

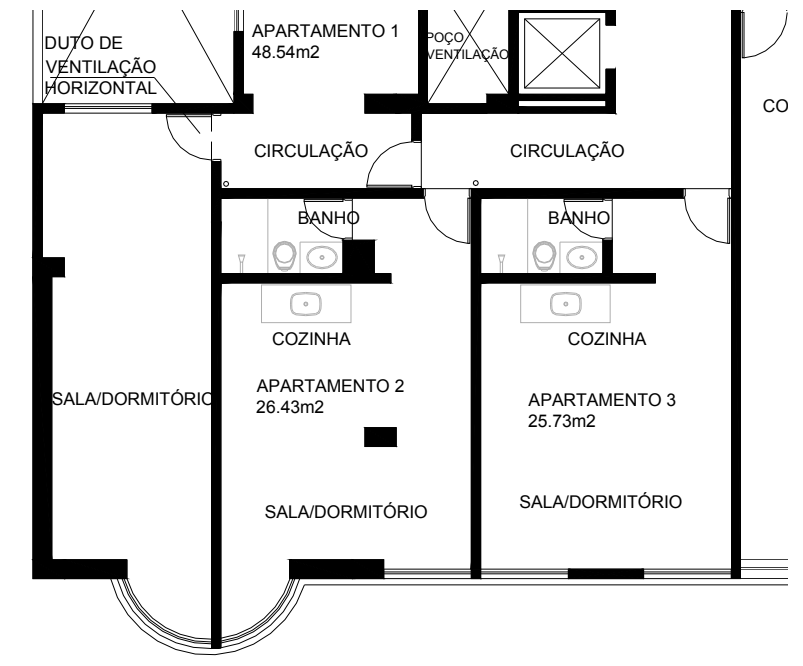

Figura 4.6 Detalhe divisão de cômodos do pavimento tipo do edifício Maria Paula.

Fonte: Assessoria Técnica Fábrica Urbana

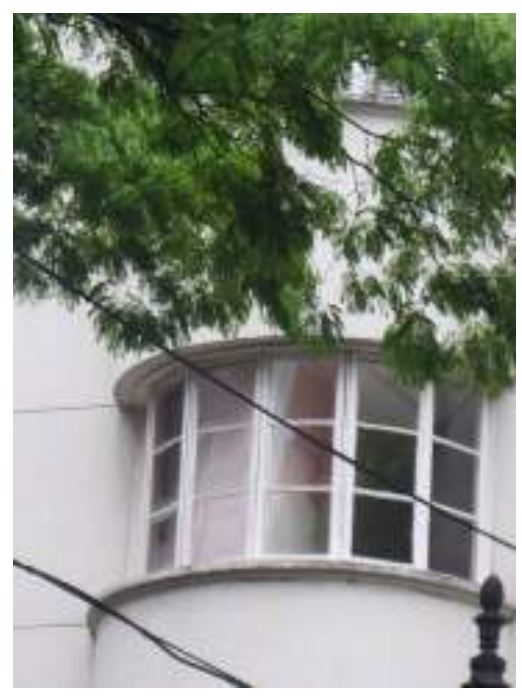

Foto 4.6 Detalhe da janela "bay window" do edifício Maria Paula. Fonte: REABILITA, 2007.

Após a entrega das unidades, alguns moradores realizaram alterações na planta por meio de novas divisões internas que compartimentam os usos de maneira tradicional. Outro fator é relacionado à divisão das esquadrias já existentes. Alguns moradores reprovam as tipologias que dividem a janela do tipo "bay window" (Foto 4.6) original do edifício, pois gostariam que a esquadria estivesse integralmente em um cômodo. Porém entendem que esta seria a única solução quando o objetivo é o maior número de unidades possível.

Outro ponto de insatisfação em relação ao projeto de reabilitação é referente às lavanderias coletivas. Os moradores mostraram-se insatisfeitos com a proposta, alegando que o espaço era desproporcional ao número de famílias do prédio e não comportava mais de quatro pessoas lavando roupa ao mesmo tempo. 


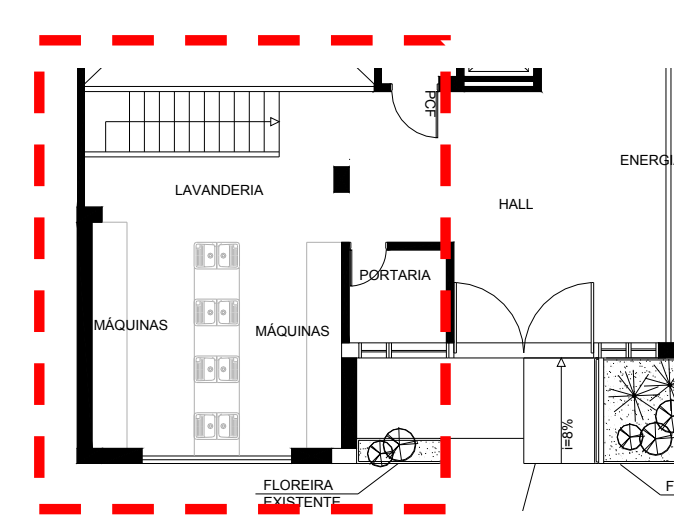

Figura 4.7 Proposta de lavanderia coletiva do edifício Maria Paula.

Fonte: Assessoria Técnica Fábrica Urbana

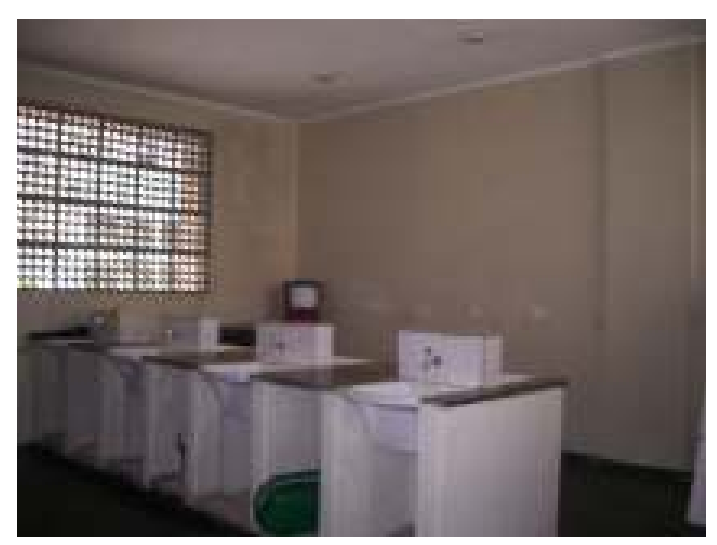

Foto 4.7 Lavanderia coletiva do edifício Maria Paula. Fonte: REABILITA, 2007.

Com o passar dos anos, cada família passou a lavar a roupa em seu próprio apartamento, pois não conseguia ter acesso ao espaço projetado. Aqueles que continuaram usando a lavanderia, passaram a utilizá-la em proveito próprio, lavando roupa para fora para complementar a renda da família. Este fato causou problemas no condomínio em relação à conta de água, dividida entre todos os condôminos, o que levou à decisão de inutilizar o espaço. Atualmente, os moradores estão estudando a idéia de utilizar o local como salão de reuniões do condomínio.

Outro ponto que desagrada os moradores é a ausência de estacionamento, pois alguns deles possuem automóvel e têm que deixar na rua ou pagar estacionamento.

Com relação à localização e à acessibilidade do prédio, os moradores não têm nenhum tipo de queixa. Muito pelo contrário, gostam de morar no edifício e sentem orgulho em falar de sua casa: "É uma delícia morar aqui. O prédio é lindo e a localização é ótima. Eu e o meu marido trabalhamos no centro, então aqui é perfeito", diz uma moradora.

De acordo com os técnicos sociais da CEF, “(...) o ponto mais alto do programa sem dúvida é a localização. Muitos moradores trabalham perto dos edifícios e não gastam com condução... (...) e se precisarem de condução eles têm abundantemente com metrô, ônibus, trem" (informação verbal) ${ }^{47}$.

\footnotetext{
${ }^{47}$ Informação fornecida pela técnica social Célia Teixeira em entrevista realizada em 22 de junho 2007.
} 


\subsection{Edifício Riskallah Jorge}

\subsubsection{Dados gerais e histórico do empreendimento}

O edifício Riskallah Jorge, entregue em 2003, localiza-se no distrito da Sé, no centro de São Paulo. A Tabela 4.3 apresenta os dados gerais do empreendimento, e a Figura 4.8 indica a localização na cidade.
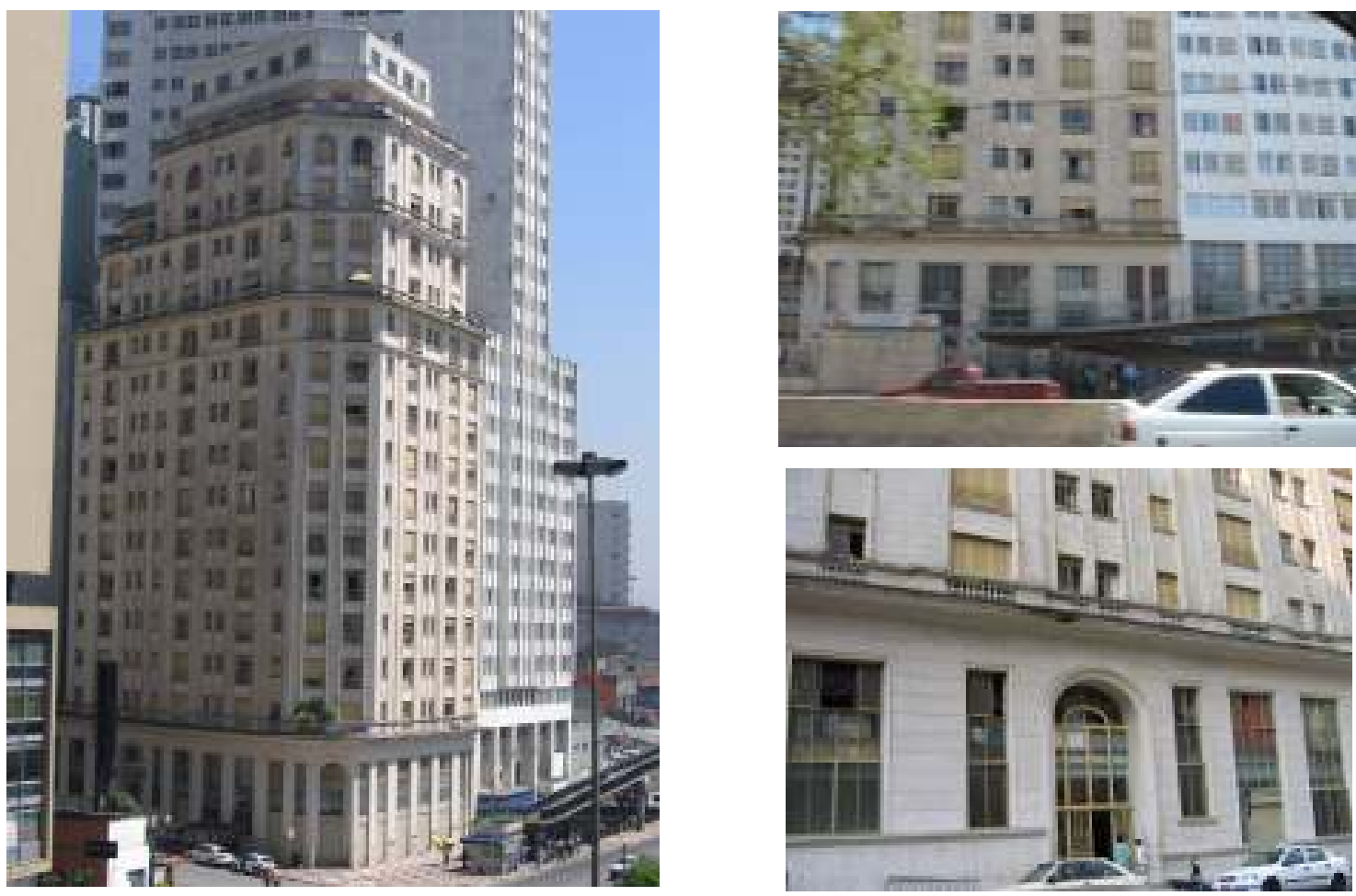

Foto 4.8 Imagens da fachada do edifício Riskallah Jorge

Tabela 4.3 Dados gerais do edifício Riskallah Jorge

\begin{tabular}{ll}
\hline Localização: & Rua Riskallah Jorge, 50 - Sé. São Paulo/SP. \\
\hline Programa: & PAR-Reforma \\
\hline Uso Inicial: & Comercial \\
\hline Número de unidades propostas: & $167 \mathrm{UH}$ \\
\hline Início da obra de reabilitação: & Agosto/ 2001 \\
\hline Data de entrega do edifício reabilitado: & Julho/ 2003 \\
\hline Tipologias: & $31 \mathrm{~m}^{2}$ - Ambiente multiuso e banheiro (162 unidades) \\
\hline Equipamentos coletivos propostos: & $45 \mathrm{~m}^{2}$ - Sala, copa, cozinha, dormitório e banheiro $(24$ unidades) \\
\hline Custo médio da unidade: & Área comunitária de usos múltiplos \\
\hline Tipo de gestão condominial: & $\mathrm{R} \$ 16.966,11^{*}$ \\
\hline Valor da parcela do finaciamento: & Terceirizada \\
\hline Valor da taxa de condomínio: & $180^{* *}$ \\
\hline
\end{tabular}

* Fonte: MALERONKA/ 2005

** Dados fornecidos pelos moradores 
Construído na década de 40, o edifício foi projetado inicialmente para ser o Hotel Pingüim da Cia Antártica Paulista. Depois foi sede do Grupo Votorantin por 20 anos, e foi vendido na década de 70 para a Real Benemérita Sociedade de Beneficência Portuguesa (MALERONKA, 2005).

Após passar alguns anos vazio, o edifício, que possui a fachada tombada pelo Conselho de Defesa do Patrimônio Histórico, Arqueológico, Artístico e Turístico (Condephaat), foi assumido pela construtora Cury Empreendimentos Imobiliários Ltda por meio do PAR. O imóvel pertencia a um único proprietário, o que facilitou o trâmite jurídico para a viabilização. O projeto, realizado pelo escritório Helena Saia Arquitetos Associados em parceria com o Movimento de Moradia do Centro (MMC), teve tempo de viabilização de dez meses (MALERONKA, 2005).
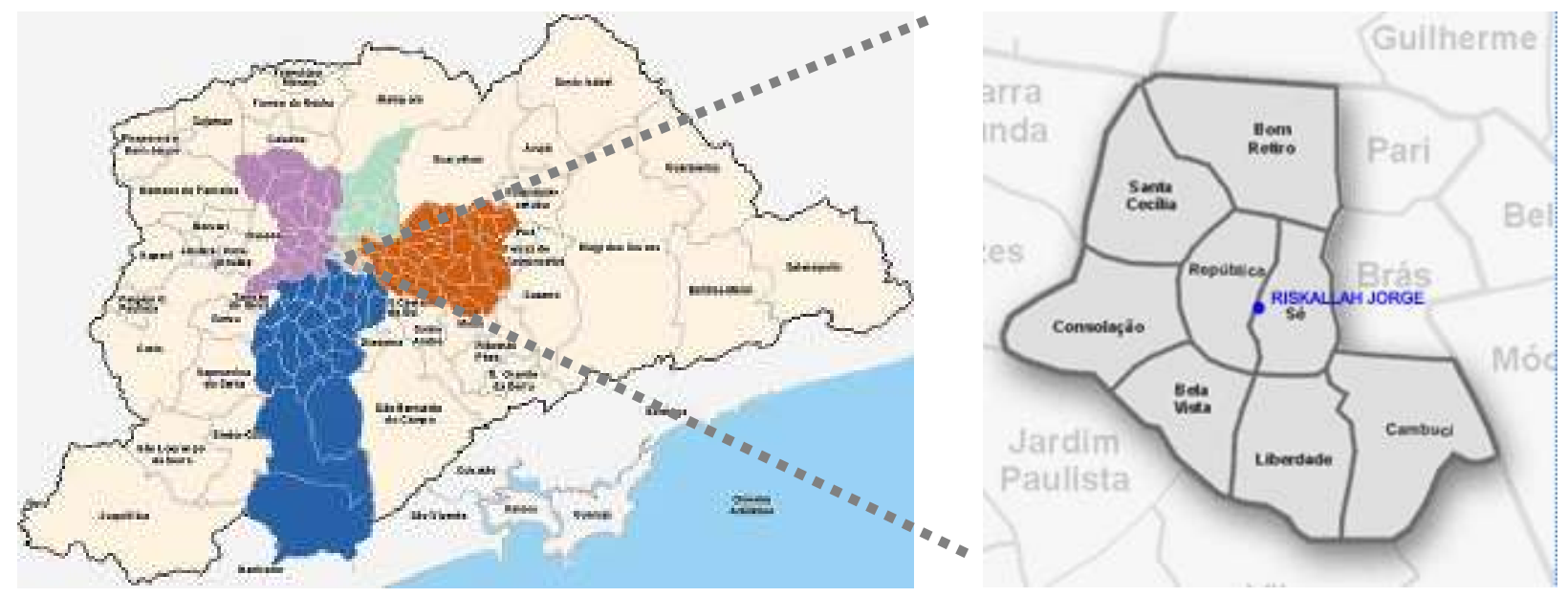

Figura 4.8 Localização da cidade de São Paulo e do edifício Riskallah Jorge.

A diretriz principal do projeto de reabilitação foi a remodelação interna dos pavimentos e a recuperação física do edifício e de todos os elementos da fachada, recuperando-os quando necessário.

Os 17 andares comerciais foram transformados em 167 unidades habitacionais de aproximadamente $31 \mathrm{~m}^{2}$. A tipologia dos apartamentos é de quitinete com sala/ dormitório conjugados, cozinha e banheiro.

O edifício, que possui estrutura em concreto armado e alvenarias de vedação em tijolos maciços recebeu um grande acréscimo de paredes que dividem os apartamentos. Estas alvenarias construídas para redistribuição interna foram executadas em blocos de concreto celular, mais leves, e assentadas com argamassa. 
As fachadas, por serem tombadas, não puderam ser pintadas. A solução encontrada foi a contratação de empresa especializada em lavagens de fachadas, trazendo à tona a cor original (Foto 4.9).
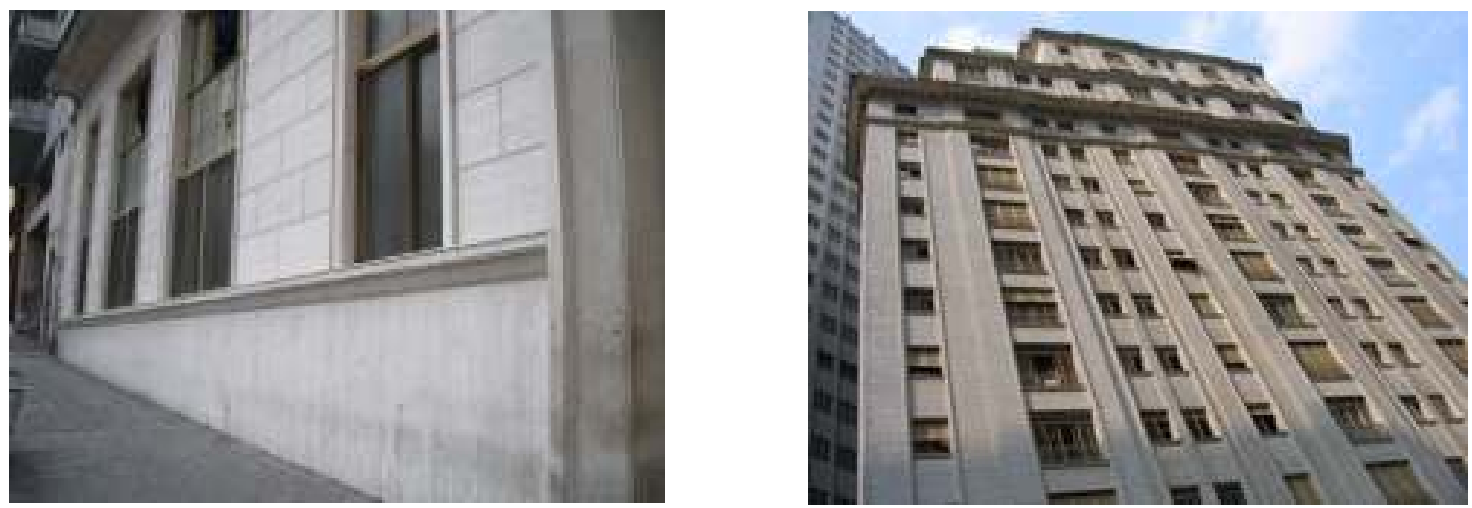

Foto 4.9 Detalhes das esquadrias e fachada do edifício Riskallah Jorge.

As antigas janelas e portas de ferro, em bom estado de conservação, foram reaproveitadas, sendo devidamente restauradas. Todas as ferragens que precisaram ser substituídas o foram por modelos compatíveis com os originais. Para as esquadrias de portas e janelas metálicas e de madeira a revisão ou substituição foi feita de modo a respeitar o desenho, o formato, e as dimensões do modelo original.

A colocação das prumadas de gás, elétrica e hidráulica exigiu equipamentos especiais para a perfuração das grossas lajes. No acabamento interno recuperou-se pisos de taco, soleiras e peitoris em mármore (CURY, 2007).

No edifício já estavam instalados três elevadores que atendiam a todos os pavimentos. Todos sofreram revisão mecânica e elétrica, sendo que as cabines foram restauradas (informação verbal) ${ }^{48}$.

\subsubsection{Aspectos sociais da Gestão Pós-Ocupação}

A mudança dos moradores para o prédio ocorreu em 2003. De acordo com os moradores, não houve nenhum tipo de trabalho técnico social da CEF neste período. Entretanto, os técnicos sociais da CEF afirmam que o trabalho foi realizado logo após a mudança dos arrendatários para o prédio.

\footnotetext{
${ }^{48}$ Informação fornecida por Fabio Cury em entrevista realizada em 2006 no âmbito do Projeto REABILITA.
} 
A gestão condominial terceirizada é realizada pela Administradora Acessional e acompanhada por um conselho fiscal formado por moradores.

Quando perguntados sobre o relacionamento com os vizinhos, alguns moradores afirmam que os problemas são muito graves. O primeiro é relacionado aos furtos constantes nos apartamentos. Alguns moradores dizem que as maiores suspeitas estão entre os próprios arrendatários e que a CEF ainda não conseguiu intervir nessa questão. Além disso, os equipamentos das áreas comuns também são constantemente furtados e danificados.

Outro grave fator é a existência de "gambiarras" nas linhas de telefone, gerando gastos excessivos e não condizentes para os proprietários das mesmas. Uma moradora afirma que sua conta de telefone, que antes não passava de $R \$ 100$, chegou a R 220 no começo do ano. Um serviço de rastreamento foi contratado e apontou que o chamado "gato" era feito por outro morador do edifício.

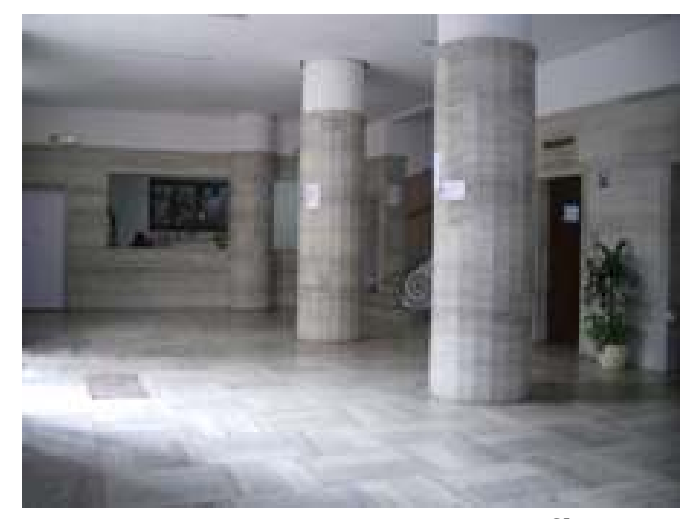

Foto 4.10 Hall de entrada do edifício Riskallah Jorge. Fonte: REABILITA, 2007.

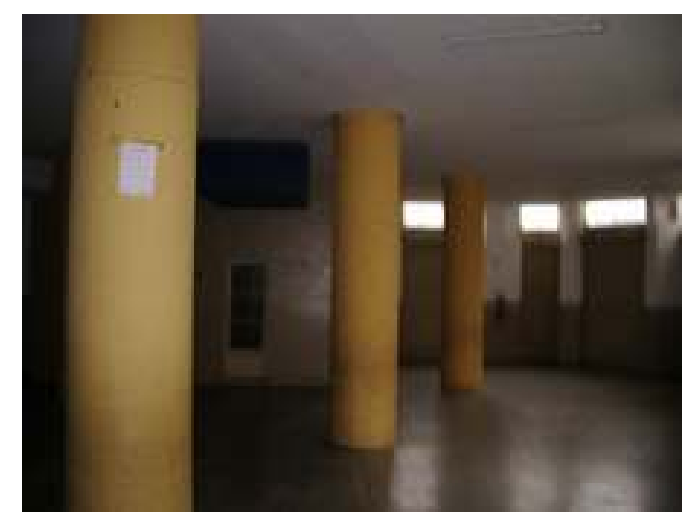

Foto 4.11 Salão comunitário do edifício Riskallah Jorge. Fonte: REABILITA, 2007.

O problema com o tráfico de drogas também é presente no prédio. De acordo com alguns moradores, isto ocorre desde a mudança. Para exemplificar, uma moradora relata que ao conversar com um policial na rua, sentiu-se muito constrangida, pois ao responder que morava no Riskallah, o policial disse: "Ah, ali no tráfico?”. A moradora completa: "Desde este dia tenho vergonha de dizer que moro aqui. Isto aqui tá abandonado. Só converso com duas pessoas. Tenho medo de morar aqui..."

Em pesquisa realizada pelo IPT ${ }^{49}$, Sanches (2008) aponta que a opinião dos moradores do edifício Riskallah Jorge com relação ao tipo de gestão condominial

${ }^{49}$ Os dados coletados na pesquisa foram obtidos através de entrevistas nos edifícios estudados adotando o seguinte critério: empreendimentos com menos de 50 unidades $-15 \%$ de entrevistas (do número de unidades); entre 51 e $100-10 \%$ de entrevistas; maior que $101-5 \%$ de entrevistas. 
empregada pelo programa é negativa. Outros aspectos elencados na pesquisa, relacionados tanto ao condomínio quanto aos moradores, foram selecionados conforme tabela a seguir (Tabela 4.4):

Tabela 4.4 Dados gerais da gestão do edifício Riskallah Jorge.

\section{Edifício Riskallah Jorge}

Avaliação da gestão condominial empregada:

\begin{tabular}{ll}
\hline Ótimo & $6 \%$ \\
\hline Bom & $19 \%$ \\
\hline Razoável & $50 \%$ \\
\hline Péssimo & $25 \%$ \\
\hline
\end{tabular}

O que destaca de bom no condomínio?

Vizinhança

O que destaca de ruim no condomínio?

Degradação

Sua vida melhorou após a mudança para o edifício?

\begin{tabular}{ll}
\hline Sim & $13 \%$ \\
\hline Não & $88 \%$ \\
\hline
\end{tabular}

Em qual aspecto considera que sua vida melhorou?

Renda

Qual o tipo de trabalho que realiza atualmente?

\begin{tabular}{ll}
\hline Formal & $56 \%$ \\
\hline Informal & $44 \%$
\end{tabular}

Quantas pessoas moram no apartamento?

2,62

Qual a renda familiar mensal?

\begin{tabular}{lc}
\hline Até 3 s.m. & $56 \%$ \\
\hline Até 6 s.m. & $44 \%$ \\
\hline Até 10 s.m. & $0 \%$ \\
\hline$>10$ s.m. & $0 \%$
\end{tabular}

Há quanto tempo mora no edifício?

\begin{tabular}{lc}
\hline Até 1 ano & $6 \%$ \\
\hline 1 a 2 anos & $13 \%$ \\
\hline 2 a 4 anos & $56 \%$ \\
\hline$>4$ anos & $25 \%$ \\
\hline Qual a forma de moradia anterior? & \\
\hline Aluguel & $75 \%$ \\
\hline Cortiço & $6 \%$ \\
\hline Favela & $6 \%$ \\
\hline Ocupação & $0 \%$ \\
\hline Outros & $13 \%$
\end{tabular}

Fonte: SANCHES, 2008. 
Podemos destacar entre os dados coletados que $75 \%$ dos moradores entrevistados não estão satisfeitos com a gestão condominial empregada no prédio. Outro dado importante é o que indica que a rotatividade de moradores é constante, pois existem desde famílias que moram há menos de um ano no prédio, até famílias que moram há mais de quatro anos. Um outro dado que chama a atenção neste estudo é o de que $88 \%$ das pessoas consideram que a vida piorou após a mudança para o edifício. Para os $12 \%$ que responderam que a vida melhorou, o aumento de renda foi o principal ponto apontado.

\subsubsection{Aspectos econômicos da Gestão Pós-Ocupação}

De acordo com os moradores, no momento da entrega das unidades, os arrendatários tomaram conhecimento de uma dívida de $\mathrm{R} \$ 41$ mil. Esta dívida, cuja origem ainda não foi identificada pelos moradores, foi paga mensalmente pelos arrendatários em rateio somado à taxa de condomínio. Após a quitação do débito, os arrendatários foram informados de que deveriam pagar uma segunda dívida, esta de IPTU, no valor de R\$ 55 mil.

Os moradores afirmam que no edifício existem muitas pessoas que estão desempregadas e não conseguem arcar com as taxas. Os que estão empregados possuem uma renda muito baixa e quase incompatível com o programa. A inadimplência da taxa de condomínio é alta e atualmente $50 \%$ das famílias estão com as taxas condominiais atrasadas mais de três meses (CEF, 2008).

Como exemplo, uma moradora que atualmente trabalha como faxineira relatou que sua renda mensal é de $\mathrm{R} \$ 380$. Somando a parcela do arrendamento, de $R \$ 180$, à taxa do condomínio, de aproximadamente $R \$ 150$, restaria somente $R \$ 50$ para a moradora pagar todas as outras contas (água, luz e telefone), além dos gastos com alimentação, transporte, lazer etc. A moradora completa: "Eu não vou pagar mais. Vou esperar a Caixa entrar em contato comigo para aí sim fazer um acordo. Alguns podem até achar ruim mas tá muito difícil... De que jeito vou pagar?".

A moradora afirma que apesar de estar sempre em dia com a CEF e com a administradora, desta vez não irá pagar porque realmente não tem condições, e acrescenta ainda que existem moradores que nunca pagaram nenhuma das 
prestações do imóvel, tampouco as parcelas do condomínio. "Tem gente que nunca pagou nada, tem gente que tem dívida de $R \$ 50$ e não resolve, aqui é assim, um quer ser mais esperto que o outro", diz um morador.

Outro problema grave que ocorreu no edifício, segundo os moradores, foi o corte de água por três meses feito pela concessionária. De acordo com a empresa, o corte foi feito por falta de pagamento, mas os moradores afirmam que pagaram todas as contas para a administradora, que não teria realizado os pagamentos corretamente.

\subsubsection{Aspectos físico-construtivos da Gestão Pós-Ocupação}

De acordo com os moradores, os principais problemas construtivos do empreendimento estão relacionados às áreas comuns e não às unidades habitacionais. Atualmente, os três elevadores estão quebrados por problemas de manutenção. Os moradores chegaram a contratar uma empresa para resolver o problema, mas os técnicos optaram por desligar os equipamentos, pois faltavam peças para o conserto (Foto 4.12).
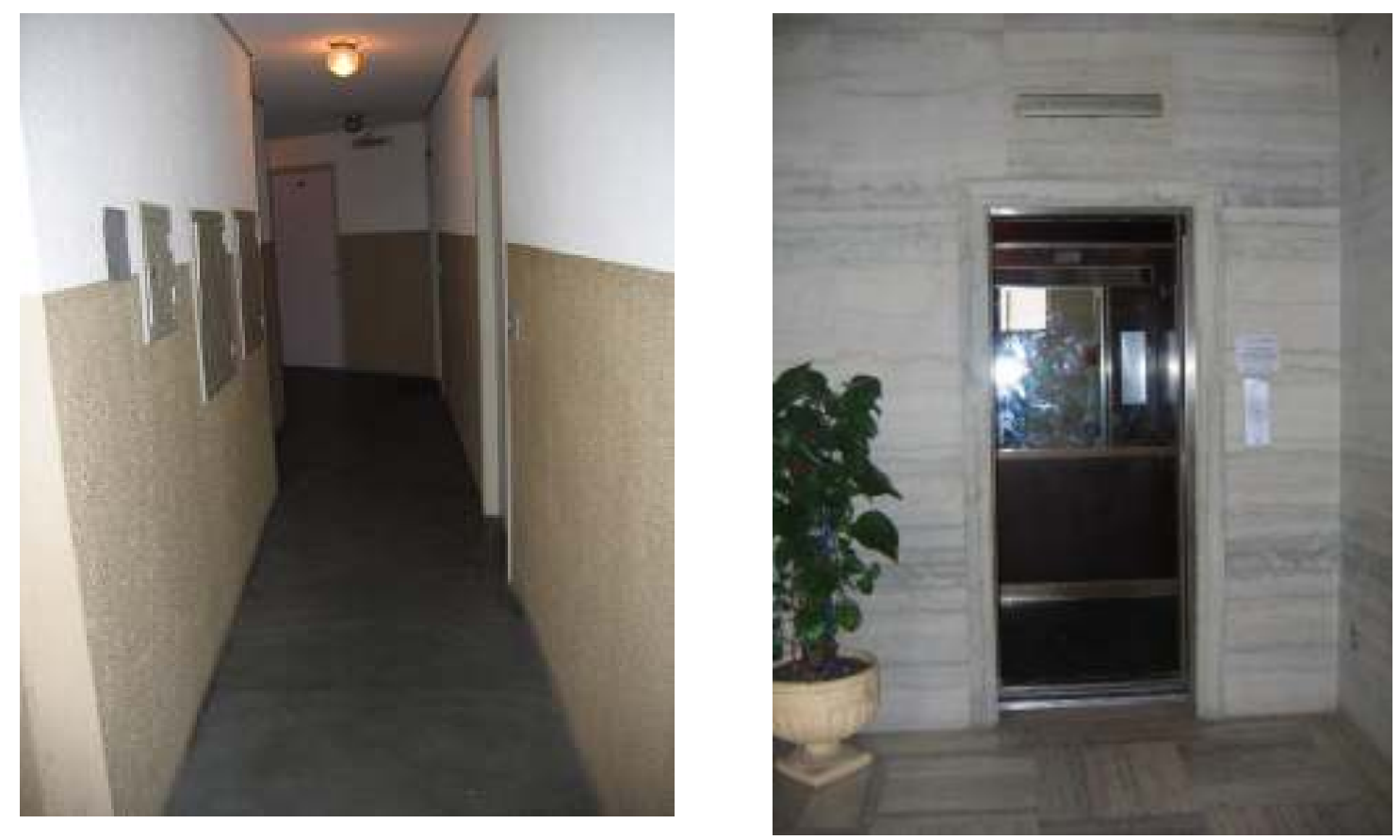

Foto 4.12 Imagens das áreas comuns e elevador do edifício Riskallah Jorge. 
Uma moradora do $10^{\circ}$ andar, com problemas de saúde, reclama que tem que subir ao menos quatro vezes os dez lances de escada "Não agüento mais! Qualquer dia vou dormir lá embaixo", diz a moradora.

Com relação às unidades habitacionais, atualmente os moradores não têm nenhuma reclamação grave. De acordo com os mesmos, no momento da mudança tiveram alguns problemas construtivos, como instalações elétricas e hidráulicas, mas que a própria construtora conseguiu resolver.

Em levantamento feito pela CEF foi apontado que, além de sérios problemas sociais e de convivência, o edifício apresentou problemas com os elevadores, uso dos espaços comuns, além de roubo de extintores e iluminação de emergência (MONICE, 2006).

Conforme gráfico a seguir (Gráfico 4.2), de acordo com levantamento ${ }^{50}$ feito pelo Projeto REABILITA, o edifício apresenta um grande número de problemas relacionados às esquadrias e ao revestimento nas unidades habitacionais. No item esquadrias, as maiores deficiências são encontradas nas persianas, onde o cordão de acionamento apresenta-se inoperante ou com mau funcionamento. No caso do revestimento, o que gera os problemas mais numerosos são as tiras de borracha para arremate entre o piso cimentado da cozinha e os tacos (a borracha colada não aceita umidade). Há poucos problemas indicados nas áreas comuns, entre eles estão: o mau funcionamento dos elevadores e o dimensionamento geral dos ralos de banheiro.

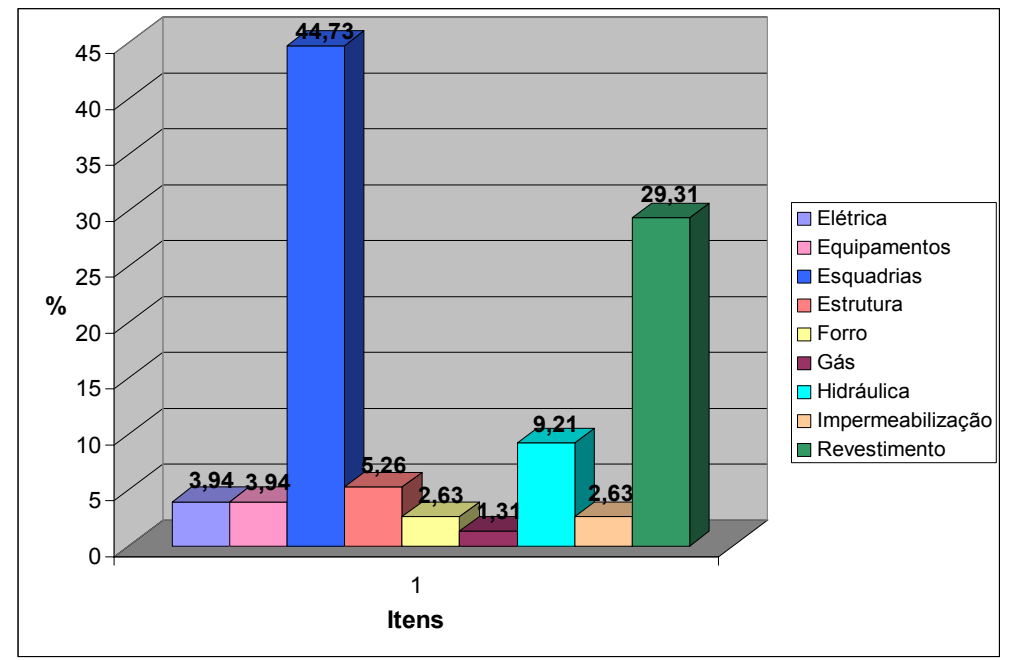

Gráfico 4.2 Porcentagens de problemas por itens construtivos nas unidades e áreas comuns do edifício Riskallah Jorge. Fonte: REABILITA, 2007.

\footnotetext{
${ }^{50}$ Os levantamentos foram realizados utilizando dados fornecidos pela CEF. Estes dados são referentes às reclamações feitas pelos moradores.
} 


\subsubsection{Aspectos arquitetônicos e urbanísticos da Gestão Pós-Ocupação}

No projeto de arquitetura realizado na reabilitação do edifício Riskallah Jorge os pavimentos tipo possuem 162 apartamentos quitinete, e cinco apartamentos de um dormitório. Segundo os moradores, os apartamentos são bons e as tipologias apresentadas atendem às necessidades.

Cada pavimento possui dez apartamentos e o térreo propõe um salão comunitário para atender a usos variados dos arrendatários, como salão de festas, reuniões condominiais, entre outros. Porém, como as crianças não têm um local de lazer identificado, o local acabou sendo utilizado para recreação. Entretanto, a administradora do prédio proibiu este uso em função de uma possível degradação patrimonial.

Quando perguntados se gostam dos apartamentos e do prédio, os moradores não hesitam em dizer que sim. O maior ponto positivo é a localização central e a proximidade com todos os serviços. Uma moradora diz "Amo meu apartamento. Batalhei muito para consegui-lo e vou fazer de tudo para ficar aqui...". 


\subsection{Edifício Fernão Salles}

\subsubsection{Dados gerais e histórico do empreendimento}

O edifício Fernão Salles, entregue em 2001, localiza-se no distrito da Sé na cidade de São Paulo. A Tabela 4.5 apresenta os dados gerais do empreendimento, e a Figura 4.9 indica a localização na cidade.
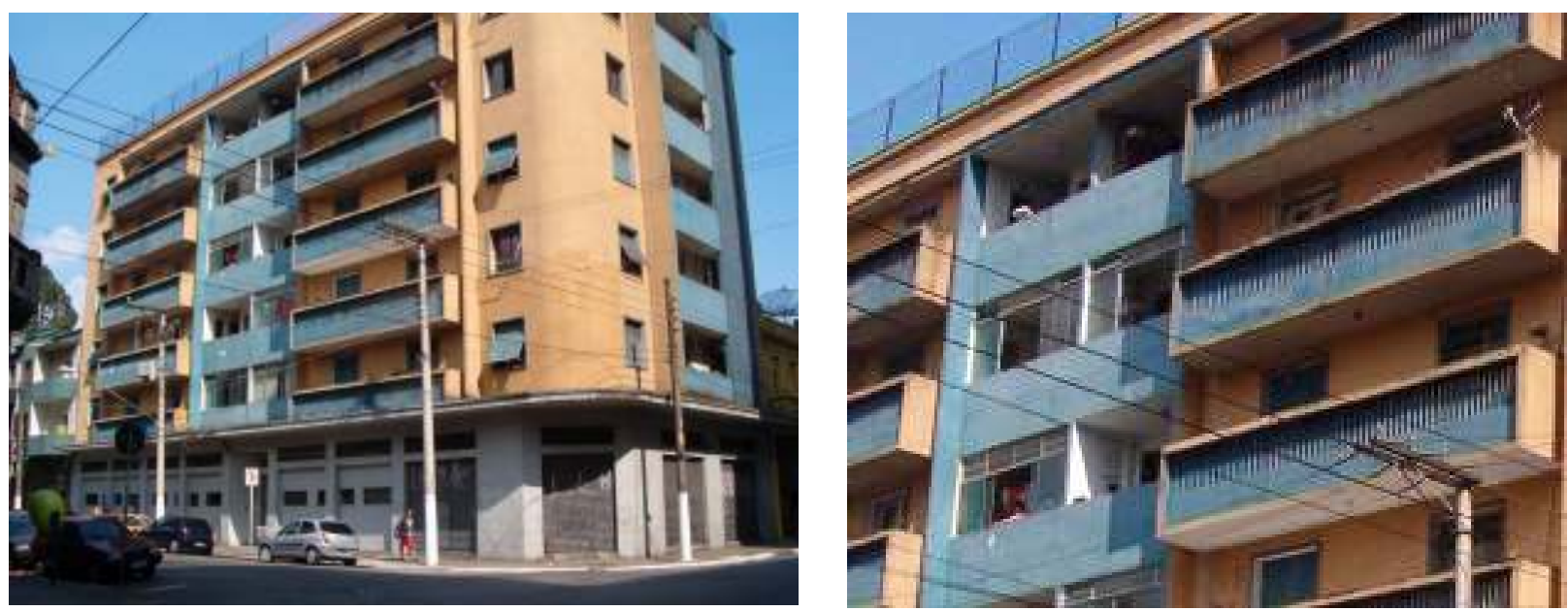

Foto 4.13 Imagens da fachada do edifício Fernão Salles.

Tabela 4.5 Dados gerais do edifício Fernão Salles.

\begin{tabular}{ll}
\hline Localização: & Rua Fernão Sales, 24 - Sé. São Paulo/SP. \\
\hline Programa: & PAR-Reforma \\
\hline Uso Inicial: & Comercial \\
\hline Número de unidades propostas: & 54 UH \\
\hline Início da obra de reabilitação: & Janeiro/ 2000 \\
\hline Data de entrega do edifício reabilitado: & Agosto/ 2001 \\
\hline Tipologias: & $32 \mathrm{~m}^{2}$ - Ambiente multiuso e banheiro \\
\cline { 2 - 2 } & $57 \mathrm{~m}^{2}$-Sala, cozinha, dormitório e banheiro \\
\hline Equipamentos coletivos propostos: & Área comunitária \\
\hline Custo médio da unidade: & Lavanderia Coletiva \\
\hline Tipo de gestão condominial: & $\mathrm{R \$} 19.300,00^{*}$ \\
\hline Valor da parcela do finaciamento: & Terceirizada \\
\hline Valor da taxa de condomínio: & $175^{* *}$ \\
\hline
\end{tabular}

* Fonte: MALERONKA/ 2005

** Dados fornecidos pelos moradores

O projeto de reabilitação do edifício é assinado pelo escritório Helena Saia Arquitetos Associados em parceria com o Movimento de Moradia do Centro (MMC) e a obra foi realizada pela construtora Cury Empreendimentos Imobiliários Ltda. 
De acordo com a CEF, o uso inicial do prédio era comercial. Entretanto, não foram fornecidos mais dados sobre a origem e histórico do prédio.

Dentre os empreendimentos analisados este é o mais simples, pois além de ser relativamente pequeno, com 54 unidades, o proprietário do imóvel era pessoa física decidida a se desfazer do bem (MALERONKA, 2005).
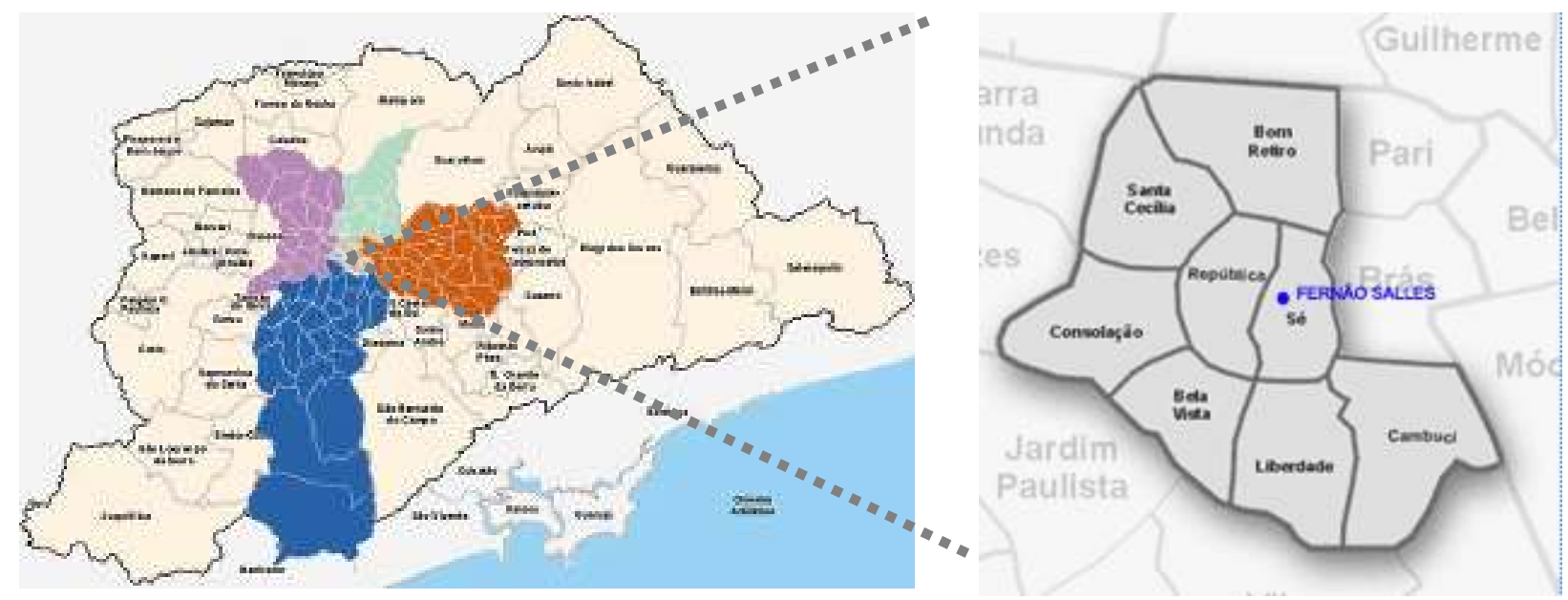

Figura 4.9 Localização da cidade de São Paulo e do edifício Fernão Salles.

\subsubsection{Aspectos sociais da Gestão Pós-Ocupação}

O edifício é conhecido como o projeto piloto dentro da política de reabilitação de edifícios vazios realizada pela parceria entre a CEF e a PMSP. A ocupação realizada em 2000 pelo Movimento de Moradia do Centro (MMC) resultou na reforma do edifício no mesmo ano e na entrega aos moradores em agosto de 2001.

As famílias que passaram a habitar o prédio já se conheciam através do movimento de moradia, o que facilitou as relações de vizinhança no edifício desde a mudança para o prédio.

A gestão condominial terceirizada é realizada pela Administradora Acessional e acompanhada por um conselho fiscal formado por moradores.

O Trabalho Técnico Social (TTS) proposto pela CEF nos primeiros seis meses de ocupação foi realizado e potencializou a união dos moradores. Com a finalização do TTS, os próprios arrendatários se organizaram para realizar um trabalho interno de conscientização e apoio às famílias.

A rotatividade de moradores é muito baixa devido, principalmente, ao pequeno número de unidades habitacionais do prédio e a organização dos arrendatários. 
São poucos os problemas encontrados nas áreas comuns devido ao cuidado que os próprios moradores possuem com o edifício. Logo após a mudança, foram contabilizados pela CEF furtos de extintores, mangueiras e iluminação de emergência, além de depredação dos espaços comuns (Foto 4.14) (MONICE, 2006). De acordo com os moradores estes problemas já foram solucionados.
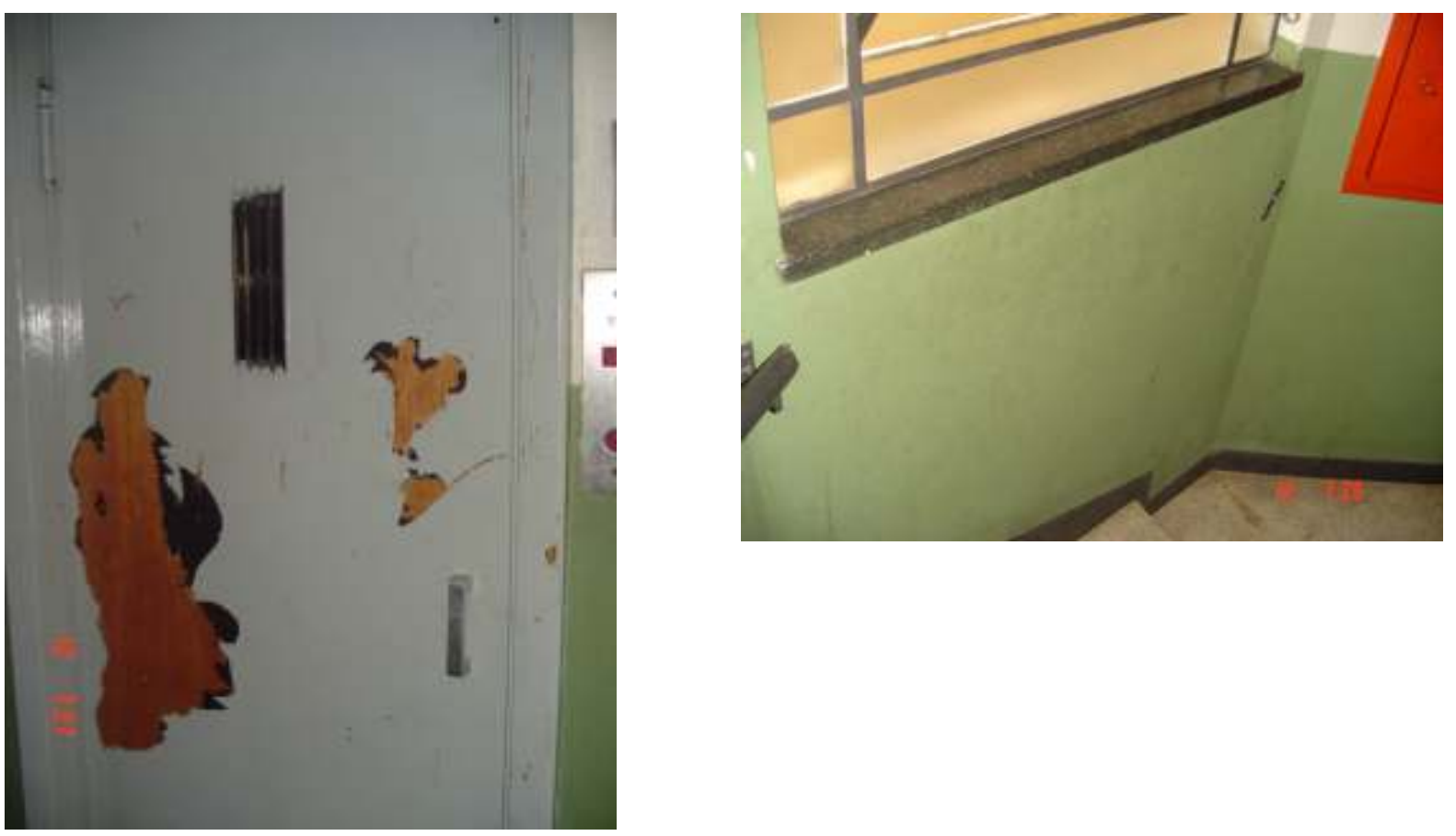

Foto 4.14 Imagens das áreas comuns do edifício Fernão Salles. Fonte: MONICE, 2006.

O contato com a administradora é pequeno, o que desagrada os moradores. "Muitas vezes tentamos contato com eles para que venham até aqui e possam resolver este problema. O retorno demora tanto que preferimos ligar direto para alguém da CEF. Acho que eles não dão conta de tantos prédios e acabam piorando o problema”, diz uma moradora entrevistada.

Em pesquisa realizada pelo IPT ${ }^{51}$, Sanches (2008) aponta que a opinião dos moradores do edifício Fernão Sales com relação ao tipo de gestão condominial empregada pelo programa é negativa. Outros aspectos elencados na pesquisa, relacionados tanto ao condomínio quanto aos moradores, foram selecionados conforme tabela a seguir (Tabela 4.6):

51 Os dados coletados na pesquisa foram obtidos através de entrevistas nos edifícios estudados adotando o seguinte critério: empreendimentos com menos de 50 unidades - 15\% de entrevistas (do número de unidades); entre 51 e 100 - 10\% de entrevistas; maior que $101-5 \%$ de entrevistas. 
Tabela 4.6 Dados gerais da gestão do edifício Fernão Salles.

Edifício Fernão Salles

Avaliação da gestão condominial empregada:

\begin{tabular}{ll}
\hline Ótimo & $0 \%$ \\
\hline Bom & $11 \%$ \\
\hline Razoável & $78 \%$ \\
\hline Péssimo & $11 \%$ \\
\hline O que destaca de bom no condomínio? &
\end{tabular}

Vizinhança

O que destaca de ruim no condomínio?

Degradação

Sua vida melhorou após a mudança para o edifício?

\begin{tabular}{ll}
\hline Sim & $78 \%$ \\
\hline Não & $22 \%$
\end{tabular}

Em qual aspecto considera que sua vida melhorou?

Auto-estima

Qual o tipo de trabalho que realiza atualmente?

\begin{tabular}{ll}
\hline Formal & $78 \%$ \\
\hline Informal & $22 \%$ \\
\hline
\end{tabular}

Quantas pessoas moram no apartamento?

3

Qual a renda familiar mensal?

\begin{tabular}{ll}
\hline Até 3 s.m. & $89 \%$ \\
\hline Até 6 s.m. & $11 \%$ \\
\hline Até 10 s.m. & $0 \%$ \\
\hline$>10$ s.m. & $0 \%$
\end{tabular}

Há quanto tempo mora no edifício?

\begin{tabular}{ll}
\hline Até 1 ano & $11 \%$ \\
\hline 1 a 2 anos & $0 \%$ \\
\hline 2 a 4 anos & $22 \%$ \\
\hline$>4$ anos & $67 \%$
\end{tabular}

Qual a forma de moradia anterior?

\begin{tabular}{ll}
\hline Aluguel & $89 \%$ \\
\hline Cortiço & $11 \%$ \\
\hline Favela & $0 \%$ \\
\hline Ocupação & $0 \%$ \\
\hline Outros & $0 \%$ \\
\hline
\end{tabular}

Fonte: SANCHES, 2008.

Os dados coletados indicam que $89 \%$ dos moradores entrevistados não estão satisfeitos com a gestão condominial empregada no prédio. Outros dados de grande relevância são os que indicam que mais da metade das famílias moram do edifício 
há mais de dois anos e que $78 \%$ das pessoas consideram que a vida melhorou após a mudança para o edifício, sendo a auto-estima o principal ponto de melhora.

\subsubsection{Aspectos econômicos da Gestão Pós-Ocupação}

A renda média dos moradores do edifício é de aproximadamente três salários mínimos, o equivalente a $\mathrm{R} \$ 1,3$ mil. Entretanto, de acordo com alguns moradores, nem todas as famílias conseguem ganhar este valor mensalmente e acabam deixando de pagar as contas do condomínio. Os gastos mensais fixos com o apartamento são de aproximadamente $R \$ 320$ entre as taxas de condomínio e arrendamento. Ainda assim, a inadimplência na taxa de condomínio é uma das menores, chegando a $10 \%$.

Devido ao grande problema hidráulico existente no prédio, o maior gasto do condomínio é com a conta de água, que chega a $\mathrm{R} \$ 2$ mil por mês. Os próprios moradores contrataram uma empresa para fazer uma reforma neste sistema, sendo que o custo foi embutido na taxa condominial.

O edifício Fernão Salles é o menor entre os cinco edifícios estudados. Entretanto, atualmente, a taxa condominial mensal paga pelos arrendatários pode ser comparada à taxa de um edifício três vezes maior, o que gera desconforto aos moradores.

Atualmente, devido ao fundo de reforma embutido na taxa do condomínio, os moradores pagam $R \$ 145$, sendo $R \$ 90$ da taxa padrão, $R \$ 39$ para conserto do elevador e R $\$ 16$ para conserto do encanamento das áreas comuns. Já a taxa de arrendamento, calculada em função do tamanho da unidade habitacional, está em torno de R\$175.

\subsubsection{Aspectos físico-construtivos da Gestão Pós-Ocupação}

Por ser um projeto piloto da CEF e da PMSP, desde o momento da mudança muitos problemas construtivos foram encontrados no edifício.

De acordo com os moradores, problemas com os elevadores existem desde a ocupação, sendo que somente um dos dois funciona atualmente. 
Outro problema existente desde a mudança dos arrendatários são os vazamentos, tanto nas áreas comuns quanto nas unidades habitacionais. Infiltração nos caixilhos novos e recuperados da fachada, refluxo de esgoto no térreo e problemas com caixilhos de madeira foram alguns dos aspectos elencados em levantamento feito pela CEF (MONICE, 2006).

A pintura da fachada também já está comprometida e ainda não recebeu nenhum tipo de manutenção. Os moradores dizem ter solicitado para a administradora, mas até a data desta pesquisa nada havia acontecido.

As esquadrias de madeira recuperadas do edifico estavam infestadas por cupins e acabaram caindo com o tempo. Foi solicitada para a administradora uma intervenção que não foi realizada. Uma moradora diz: "É um absurdo eles não cuidarem disso aqui. Este prédio é deles, o interesse é deles. Eu não vou quitar o arrendamento porque se só um ou dois quitarem, o resto vai ficar assim, abandonado por eles. E eu não quero morar num lugar sem dono".

\subsubsection{Aspectos arquitetônicos e urbanísticos da Gestão Pós-Ocupação}

A nova distribuição de espaços dentro do edifício, em geral agrada aos moradores. As tipologias existentes variam entre 32 e $57 \mathrm{~m}^{2}$ sendo oito apartamentos por andar. No térreo há um hall de entrada, escada, elevadores e apartamentos térreos. Na cobertura está localizada lavanderia coletiva e alguns apartamentos de dois dormitórios.

Alguns moradores entrevistados disseram sentir falta de áreas de lazer para as crianças. Porém, entendem que o prédio está em um terreno enxuto e por isso não seria possível.

A localização é uma das características que mais agradam aos moradores. $O$ acesso fácil aos transportes coletivos, comércio e serviços da área central são pontos muito importantes para os arrendatários.

Quando perguntados se aprovam o projeto, os moradores entrevistados foram unânimes em dizer que sim. "Mesmo com todos os problemas que temos aqui adoramos nossa casa. Lutamos muito para conseguir e é por isso que lutamos tanto para conservar", diz uma moradora. 


\subsection{Edifício Olga Benário}

\subsubsection{Dados gerais e histórico do empreendimento}

O edifício Olga Benário Prestes, entregue em 2002, localiza-se no distrito Belém na cidade de São Paulo-SP. A Tabela 4.7 apresenta os dados gerais do empreendimento, e a Figura 4.10 indica a localização na cidade.
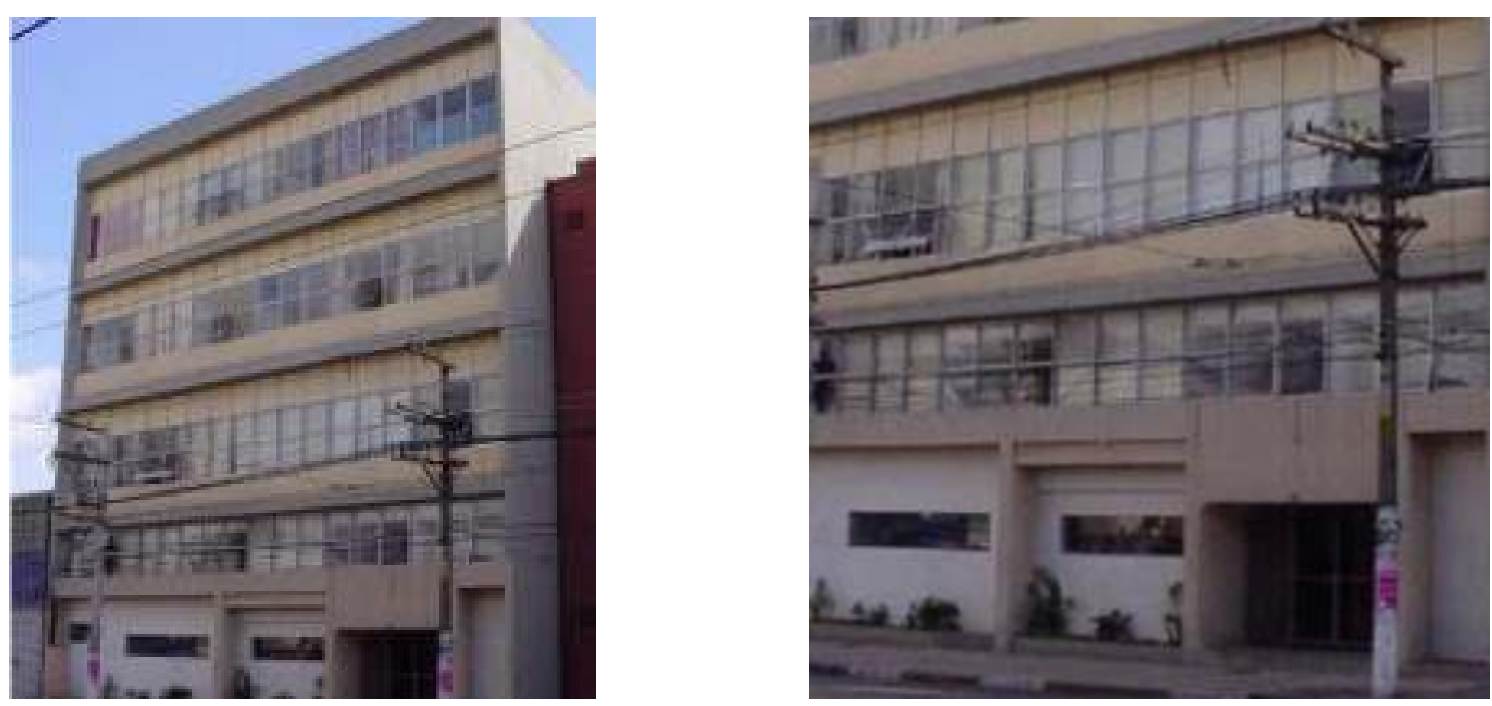

Foto 4.15 Imagens da fachada do edifício Olga Benário.

Fonte: MONICE, 2006.

Tabela 4.7 Dados gerais do edifício Olga Benário.

\begin{tabular}{ll}
\hline Localização: & Av. Celso Garcia, 787 - Brás. São Paulo/SP. \\
\hline Programa: & PAR-Reforma \\
\hline Uso Inicial: & Comercial \\
\hline Número de unidades propostas: & 84 UH \\
\hline Início da obra de reabilitação: & Março/ 2001 \\
\hline Data de entrega do edifício reabilitado: & Novembro/ 2002 \\
\hline Tipologias: & $24 \mathrm{~m}^{2}$ - Ambiente multiuso e banheiro \\
\hline Equipamentos coletivos propostos: & $29 \mathrm{~m}^{2}-$ Ambiente multiuso e banheiro \\
\hline & Área comunitária \\
\hline Custo médio da unidade: & Churrasqueira \\
\hline Tipo de gestão condominial: & Escritório de apoio e administração \\
\hline Valor da parcela do finaciamento: & $\mathrm{R} \$ 34.110,04^{*}$ \\
\hline Valor da taxa de condomínio: & Terceirizada \\
\hline
\end{tabular}

* Fonte: MALERONKA/ 2005

** Dados fornecidos pelos moradores 
O edifício foi construído na década de 50 para ocupar uma fábrica. Em 1960, foi adquirido pelo BANESPA e passou a exercer papel de agência e escritório do banco até 1990. Em dezembro de 1999, foi ocupado por cerca de 300 famílias filiadas a Unificação das Lutas de Cortiços (ULC).

Das famílias que participaram da ocupação, 80 permaneceram morando no prédio enquanto o movimento e a assessoria técnica procuravam uma solução para as demais (MALERONKA, 2005).

A Cooperativa de Trabalho Interdisciplinar (Integra) desenvolveu os projetos e orçamentos em parceria com a ULC, e o contrato foi assumido pela construtora Tarraf.

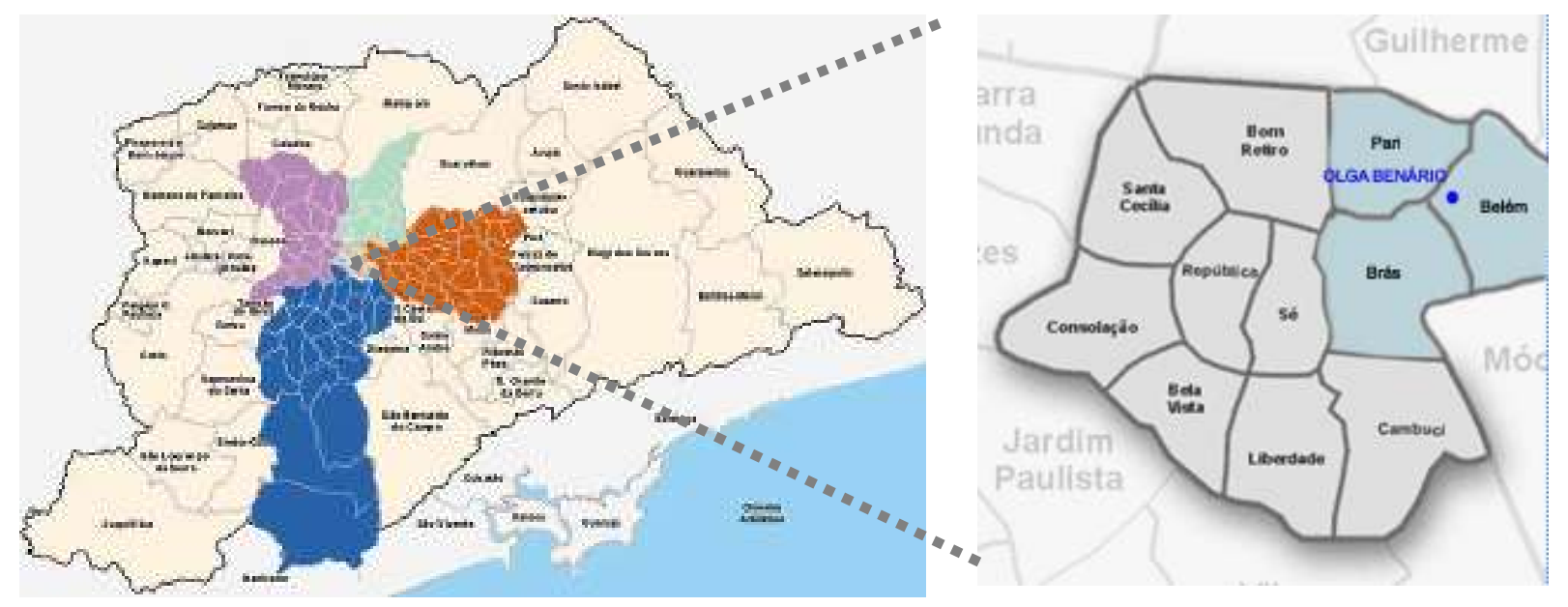

Figura 4.10 Localização da cidade de São Paulo e do edifício Olga Benário.

De acordo com Maleronka (2005), foram elaboradas oito versões para adequação do edifício ao novo programa; a primeira contava com 68 unidades habitacionais, com apartamentos de até $55 \mathrm{~m}^{2}$. Entretanto, o valor limite de aquisição por unidade habitacional na época ainda estava em $R \$ 20$ mil, o que limitou os apartamentos a áreas entre $24 \mathrm{~m}^{2}$ e $29 \mathrm{~m}^{2}$.

Originalmente o imóvel era composto por cinco pavimentos, sendo que térreo com pé direito duplo. Para permitir a viabilidade econômica, foi necessário criar um mezanino intermediário sobre a área da agência permitindo a criação de mais nove unidades totalizando 84 .

O empreendimento possui 28 tipologias diferentes, prevalecendo as unidades quitinetes. A menor unidade é uma quitinete com $24 \mathrm{~m}^{2}$ de área útil, e o maior apartamento possui um quarto, sala, cozinha e banheiro totalizando $29 \mathrm{~m}^{2}$ de área 
útil. Cada pavimento possui cerca de 18 unidades habitacionais e uma área de lavanderia comum.

No térreo foi implantado o salão comunitário e na cobertura uma área de lazer com churrasqueira. Não existe playground ou mesmo quadra de esportes. O único elevador do imóvel atende ao térreo, primeiro, segundo, terceiro e quarto pavimentos. Não existe parada na cobertura (YOLLE NETO, 2005).

Por ser um imóvel comercial, os únicos pontos de ventilação e iluminação ocorriam nas fachadas da frente e do fundo, uma vez que o edifício não possuía recuo lateral, o que era permitido na época de sua construção. Com isso era impossível implantar apartamentos no centro do edifício sem que fosse criada uma alternativa para a ventilação dos mesmos.

A solução arquitetônica encontrada foi a abertura de quatro fossos de ventilação na parte central (Figura 4.11). A dimensão de cada fosso foi calculada baseada nos índices de iluminação e ventilação dos apartamentos situados no térreo. Isso permitiu tornar o pavimento térreo claro e com circulação de ar constante. A criação desses fossos de iluminação e ventilação permitiu que os apartamentos ficassem voltados ao interior do edifício. Dessa forma, o acesso às unidades é feito através de um corredor de circulação interno, o qual possui iluminação natural também através dos fossos (YOLLE NETO, 2005).

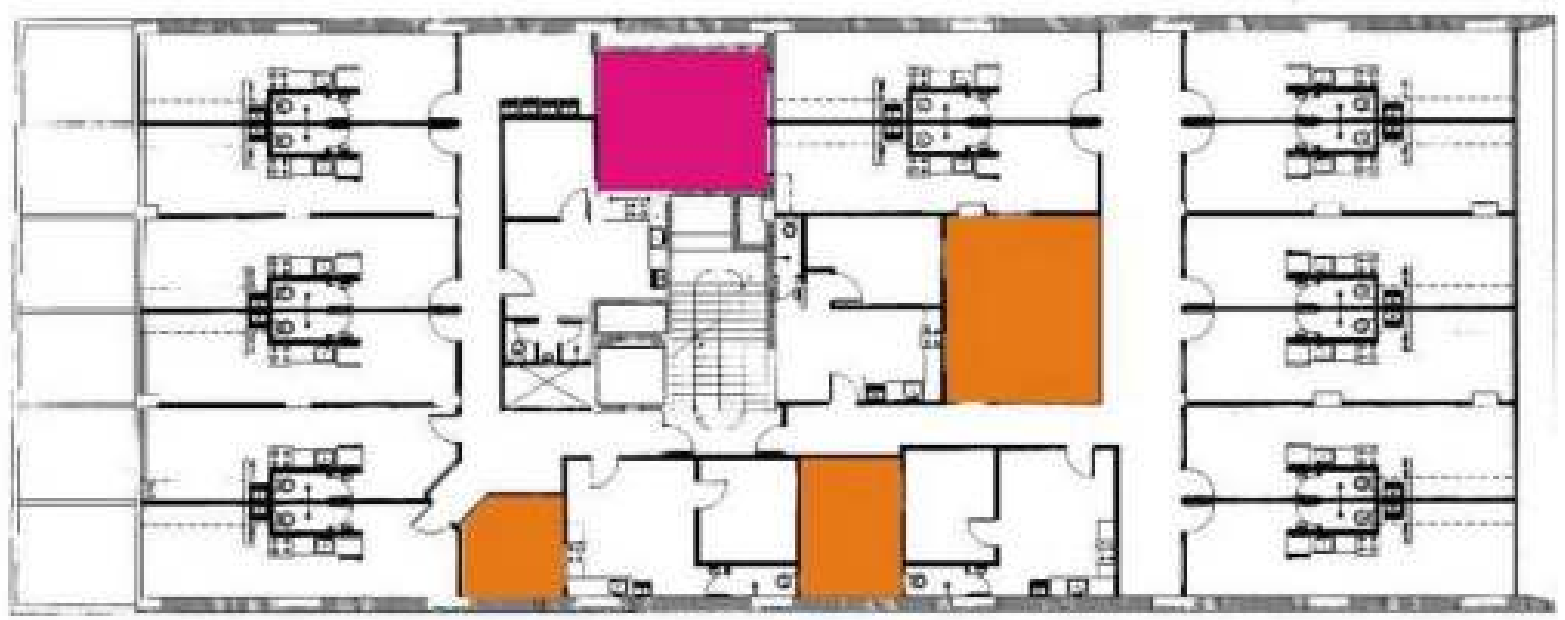

Figura 4.11 Planta do pavimento tipo do edifício Olga Benário com indicação das aberturas. Fonte: YOLLE NETO, 2005. 


\subsubsection{Aspectos sociais da Gestão Pós-Ocupação}

O fato de os moradores se conhecerem desde o momento da ocupação do edifício, em 1999, colabora para as relações de vizinhança existentes. Das 300 famílias pertencentes ao movimento de moradia que ocuparam o prédio, 80 foram selecionadas para fazer parte do programa e arrendar uma unidade habitacional.

A rotatividade de moradores desde então é muito baixa comparada à dos outros edifícios.

De acordo com os moradores entrevistados, não houve trabalho social realizado pela CEF. Porém, como a demanda já era bastante unida e com uma liderança presente, o trabalho foi considerado desnecessário. Os próprios moradores se ajudaram e ainda se ajudam, mesmo não fazendo mais parte do movimento de luta por moradia.

Até 2007, a administração condominial terceirizada foi realizada pela Administradora Principal. Em 2008, a Administradora Martins assumiu o edifício junto com um conselho fiscal formado por moradores.

Em pesquisa realizada pelo IPT ${ }^{52}$, Sanches (2008) aponta que a opinião dos moradores do edifício Olga Benário com relação ao tipo de gestão condominial empregada pelo programa é negativa. Outros aspectos elencados na pesquisa, relacionados tanto ao condomínio quanto aos moradores, foram selecionados conforme tabela a seguir (Tabela 4.8):

${ }^{52}$ Os dados coletados na pesquisa foram obtidos através de entrevistas nos edifícios estudados adotando o seguinte critério: empreendimentos com menos de 50 unidades $-15 \%$ de entrevistas (do número de unidades); entre 51 e $100-10 \%$ de entrevistas; maior que $101-5 \%$ de entrevistas. 
Tabela 4.8 Dados gerais da gestão do edifício Olga Benário.

\section{Edifício Olga Benário Prestes}

Avaliação da gestão condominial empregada:

\begin{tabular}{lc}
\hline Ótimo & $17 \%$ \\
\hline Bom & $25 \%$ \\
\hline Razoável & $50 \%$ \\
\hline Péssimo & $8 \%$ \\
\hline O que destaca de bom no condomínio? &
\end{tabular}

O que destaca de bom no condomínio?

Vizinhança

O que destaca de ruim no condomínio?

Degradação

Sua vida melhorou após a mudança para o edifício?

\begin{tabular}{ll}
\hline Sim & $58 \%$ \\
\hline Não & $42 \%$
\end{tabular}

Em qual aspecto considera que sua vida melhorou?

Auto-estima

Qual o tipo de trabalho que realiza atualmente?

\begin{tabular}{ll}
\hline Formal & $50 \%$ \\
\hline Informal & $50 \%$ \\
\hline
\end{tabular}

Quantas pessoas moram no apartamento?

2,33

Qual a renda familiar mensal?

\begin{tabular}{ll}
\hline Até 3 s.m. & $58 \%$ \\
\hline Até 6 s.m. & $33 \%$ \\
\hline Até 10 s.m. & $8 \%$ \\
\hline$>10$ s.m. & $0 \%$
\end{tabular}

Há quanto tempo mora no edifício?

\begin{tabular}{lc}
\hline Até 1 ano & $8 \%$ \\
\hline 1 a 2 anos & $0 \%$ \\
\hline 2 a 4 anos & $0 \%$ \\
\hline$>4$ anos & $92 \%$
\end{tabular}

Qual a forma de moradia anterior?

\begin{tabular}{ll}
\hline Aluguel & $67 \%$ \\
\hline Cortiço & $33 \%$ \\
\hline Favela & $0 \%$ \\
\hline Ocupação & $0 \%$ \\
\hline Outros & $0 \%$
\end{tabular}

Fonte: SANCHES, 2008.

Os dados coletados indicam que $58 \%$ dos moradores entrevistados não estão satisfeitos com a gestão condominial empregada no prédio. Outros dados de grande relevância são os que indicam que quase todas as famílias moram do edifício há 
aproximadamente quatro anos, indicando baixa rotatividade e $58 \%$ das pessoas consideram que a vida melhorou após a mudança para o edifício, sendo a autoestima o principal ponto de melhora.

\subsubsection{Aspectos econômicos da Gestão Pós-Ocupação}

A renda média dos moradores do edifício é de aproximadamente três salários mínimos, o equivalente a $\mathrm{R} \$ 1,3$ mil. Entretanto, de acordo com alguns moradores, nem todas as famílias conseguem ganhar este valor mensalmente e acabam deixando de pagar as contas do condomínio. Os gastos mensais fixos com o apartamento são de aproximadamente $\mathrm{R} \$ 310$ entre as duas taxas, sendo que a inadimplência na taxa de condomínio atualmente chega a $20 \%$.

A taxa de arrendamento varia de acordo com o tamanho da unidade habitacional e pode variar entre $R \$ 160$ a $R \$ 196$. Já a taxa condominial é formada por um valor fixo somado a uma taxa de manutenção dos elevadores ${ }^{53}$. Para a realização da manutenção do elevador, foi assinado um contrato com uma empresa terceirizada. Porém, a empresa não efetuou o trabalho, alegando tratar-se de um equipamento muito antigo. Sendo assim, o elevador, que só funcionou algumas vezes, continua parado. Ainda assim esta taxa é paga mensalmente pelos moradores, pois a multa para rescisão do contrato possui um valor muito alto.

\subsubsection{Aspectos físico-construtivos da Gestão Pós-Ocupação}

De acordo com os moradores entrevistados, o edifício possui alguns problemas construtivos desde o momento da mudança. Começando pelo elevador, único para as 84 unidades, e que não pode ser consertado.

Outro grande problema registrado pelos arrendatários são as infiltrações e vazamentos de água tanto nas áreas comuns, quanto nas unidades habitacionais. Uma moradora afirma que visitou diversas unidades com problemas de alagamento.

\footnotetext{
${ }^{53}$ Os moradores entrevistados não souberam dizer o valor da taxa de manutenção do elevador.
} 
De acordo com levantamento feito pela CEF, os maiores problemas encontrados no edifício são o elevador recuperado, drenagem de águas pluviais nos corredores abertos, umidade no páteo de recreação e infiltração nos caixilhos recuperados da fachada (MONICE, 2006).

Os moradores afirmam que diversas tentativas de contato com a administradora foram feitas a fim de resolver os problemas existentes no edifício. Porém, nada foi feito até a data desta pesquisa. Sendo assim, resolveram procurar a CEF diretamente. Um engenheiro visitou o prédio e fez um relatório dos problemas encontrados. Entretanto, os problemas permaneceram e os arrendatários não tiveram mais tiveram contato com os técnicos da CEF.

\subsubsection{Aspectos arquitetônicos e urbanísticos da Gestão Pós-Ocupação}

O projeto de reabilitação do edifício Olga Benário pode ser considerado bastante complexo devido à quantidade de tipologias encontradas. A preocupação com a necessidade de iluminação e ventilação adequadas a todas as unidades desencadeou nesta diversidade de plantas (YOLLE NETO, 2005).

As unidades, que variam entre 24 a $29 \mathrm{~m}^{2}$, são predominantemente quitinetes. No térreo existe uma entrada principal com recepção e controle de acesso, além de uma área comunitária de usos múltiplos (inicialmente planejada como área comercial para locação, mas o contrato do PAR não permite este tipo de transação nos edifícios). Cada andar possui, além das 18 unidades habitacionais, uma lavanderia coletiva.

$\mathrm{Na}$ cobertura foram projetadas área comunitária e churrasqueira, bastante utilizadas pelos arrendatários.

Alguns moradores afirmam que as unidades são muito pequenas e que sentem dificuldade na acomodação da família. Os ambientes multiusos, ou quitinetes, não atendem a casais com filhos, que optam por dividir o ambiente em dois para ter mais privacidade. Esta divisão acaba prejudicando os ambientes que ficam sem a iluminação e ventilação adequadas (Foto 4.16). 

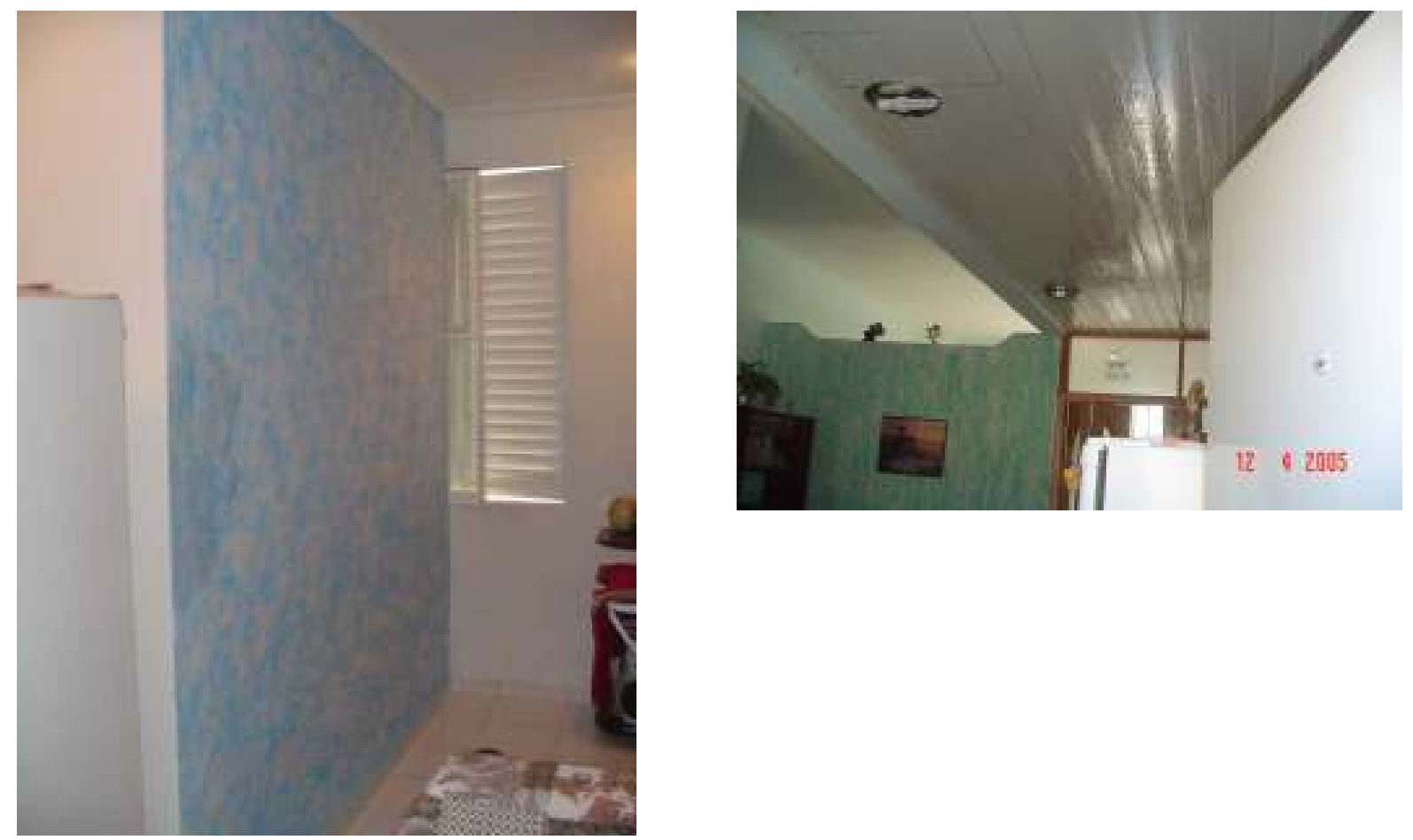

Foto 4.16 Imagens internas das unidades habitacionais do edifício Olga Benário. Fonte: MONICE, 2006.

Para os moradores, a localização é sem dúvida o ponto forte do projeto, e quando perguntados se mudariam definitivamente para o edifício, afirmam que sim. 


\subsection{Edifício Labor}

\subsubsection{Dados gerais e histórico do empreendimento}

O edifício Labor/ Brigadeiro Tobias, entregue em 2003, localiza-se no distrito da Sé na cidade de São Paulo-SP. A Tabela 4.9 apresenta os dados gerais do empreendimento, e a Figura 4.12 indica a localização na cidade.
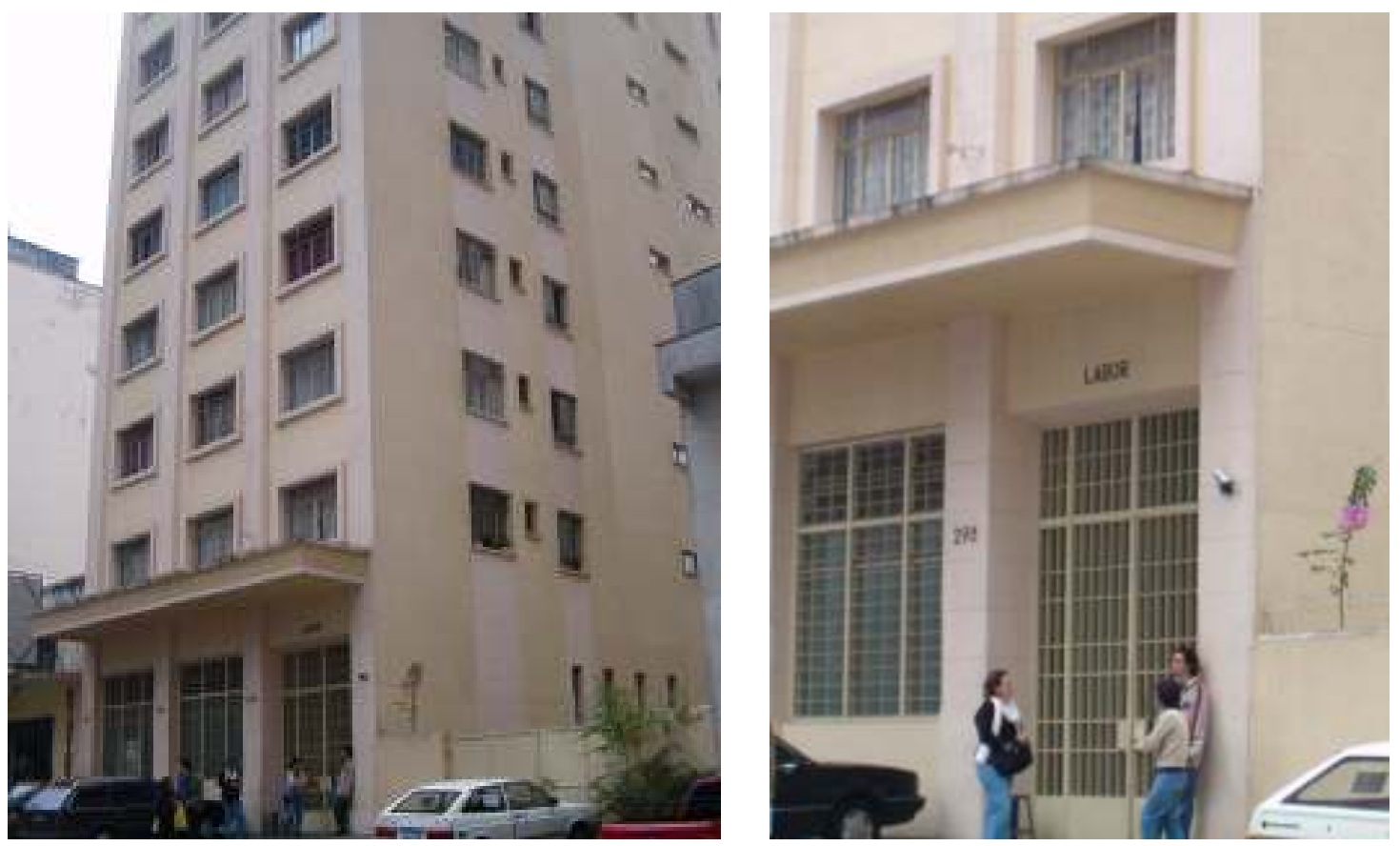

Foto 4.17 Imagens da fachada do edifício Labor.

Tabela 4.9 Dados gerais do edifício Labor.

\begin{tabular}{ll}
\hline Localização: & Rua Brigadeiro Tobias, 290 - Sé. São Paulo/SP. \\
\hline Programa: & PAR-Reforma \\
\hline Uso Inicial: & Comercial \\
\hline Número de unidades propostas: & $84 \mathrm{UH}$ \\
\hline Início da obra de reabilitação: & Agosto/ 2002 \\
\hline Data de entrega do edifício reabilitado: & Dezembro/ 2003 \\
\hline Tipologias: & $31 \mathrm{~m}^{2}-$ Ambiente multiuso e banheiro (81 unidades) \\
\hline Equipamentos coletivos propostos: & $\begin{array}{l}31 \mathrm{~m}^{2}-\text { Ambiente multiuso e banheiro - adaptados para pessoas com } \\
\text { deficiência }(03 \text { unidades })\end{array}$ \\
\hline Custo médio da unidade: & Área comunitária \\
\hline Tipo de gestão condominial: & $\mathrm{R} \$ 28.812,28^{*}$ \\
\hline Valor da parcela do finaciamento: & Terceirizada \\
\hline Valor da taxa de condomínio: & $240^{* *}$ \\
\hline
\end{tabular}

* Fonte: MALERONKA/ 2005

** Dados fornecidos pelos moradores 
Pertencente a Fundação Rede Ferroviária de Seguridade Social (REFER), o edifício foi ocupado pelo movimento de moradia (MSTC e UMM/ Oeste) em 24 de outubro de 1999, após 10 anos de ociosidade.

Aproximadamente 38 famílias se alojaram no local, que possuía oito pavimentos, sendo o térreo com pé-direito duplo.

O terreno, com $718 \mathrm{~m}^{2}$, possui uma área construída de $5.400 \mathrm{~m}^{2} \mathrm{com}$ uso original projetado para escritórios da Rede Ferroviária Federal. A tecnologia construtiva do edifício é a tradicional, em concreto armado com vedações em tijolos.

O projeto de reabilitação, viabilizado pela Integra - Cooperativa de Trabalho Interdisciplinar - em parceria com o Grão - Grupo de Assessoria para Ações Sustentáveis - foi assumido pela Construtora Tarraf Ltda (MALERONKA, 2005).
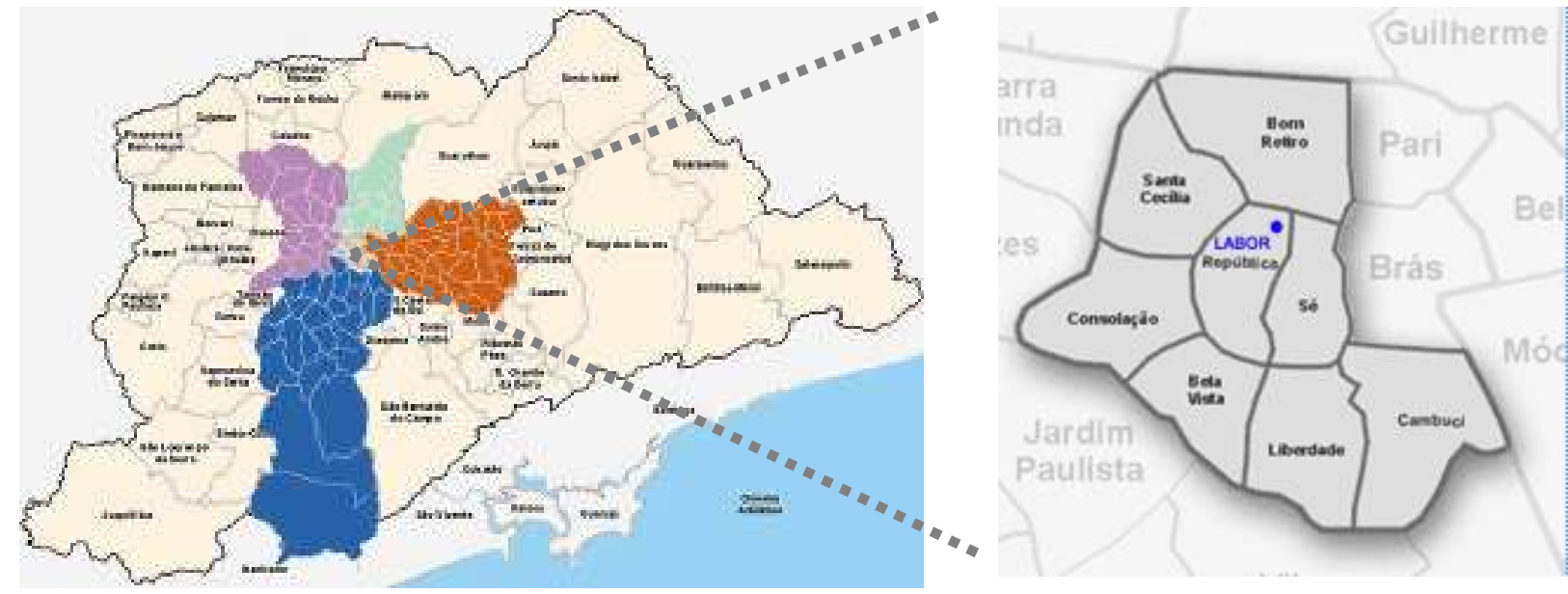

Figura 4.12 Localização da cidade de São Paulo e do edifício Labor.

O novo projeto possui 84 unidades habitacionais, sendo que cada pavimento tipo conta com oito apartamentos. Algumas intervenções ocorreram a fim de aproveitar a tipologia do edifício, como a construção de dois mezaninos, um na parte frontal e outro na parte posterior, utilizando as áreas com pé-direito duplo, e a construção do nono pavimento com o objetivo de viabilizar mais unidades (Figura 4.13).

Devido a este acréscimo de área, a CEF e a Assessoria técnica solicitaram os projetos estruturais do edifício para assegurar a viabilidade técnica. Como o projeto estrutural original não foi encontrado, foi solicitado ao proprietário do prédio novo laudo técnico das fundações, que indicou sérios problemas estruturais devido à baixa resistência do concreto nos andares inferiores. O fato acarretou em uma 
reforma a fim de garantir a integridade da edificação através de reforços estruturais ${ }^{54}$ (MALERONKA, 2005)..
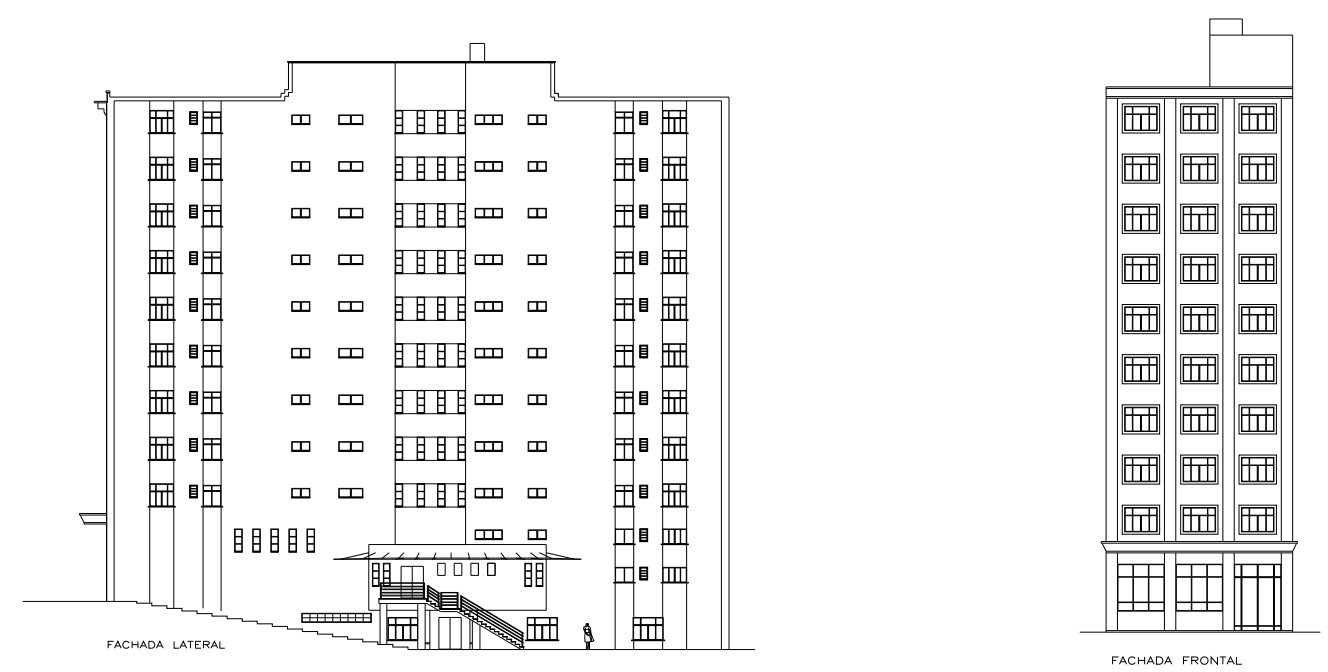

Figura 4.13 Fachada lateral e frontal do edifício Labor.

Fonte: Integra

No nono andar foram utilizados alvenaria estrutural e outros elementos estruturais mais leves para que a fundação resistisse mesmo após os reforços.

Como parte do projeto de reabilitação, no subsolo (que existe devido a um desnível do terreno) foi projetado um grande salão. Já na parte posterior do terreno existe uma edificação de dois andares para o qual ainda está sendo pensado o melhor uso. Existe a possibilidade de utilizar a área para aulas de computação ou cooperativas, ou seja, algo que gere renda para o condomínio (Foto 4.18).
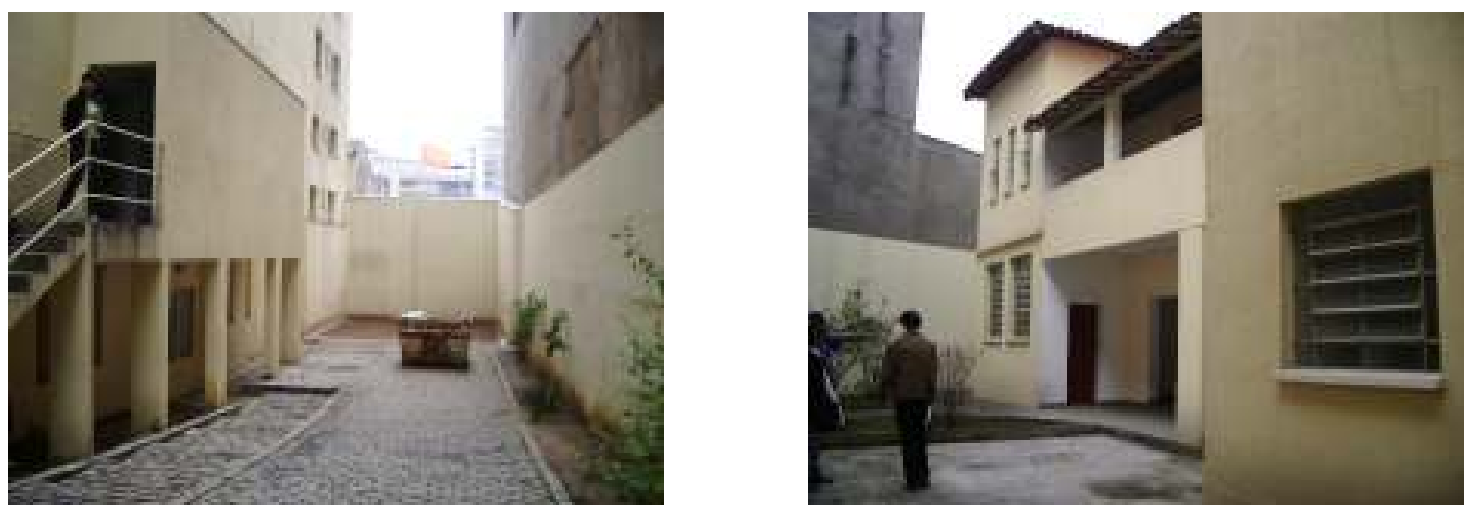

Foto 4.18 Imagens das áreas comuns externas do edifício Labor.

\footnotetext{
${ }^{54}$ Segundo Maleronka (2005), a diretoria de patrimônio da REFER orçou demolir o prédio, orçou o reforço estrutural e demorou cerca de quatro meses para tomar a decisão. $\mathrm{O}$ orçamento do reforço estrutural ficou em R $\$ 400$ mil e a CEF concordou em contratar a obra. Decidiu-se, por fim, descontar o valor do reforço estrutural do valor do imóvel.
} 
Os apartamentos de aproximadamente $30 \mathrm{~m}^{2}$ acolhem desde pessoas sozinhas até famílias de cinco pessoas (Figura 4.14). Existe somente uma área com abertura para ventilação e iluminação, que normalmente é utilizada como quarto.

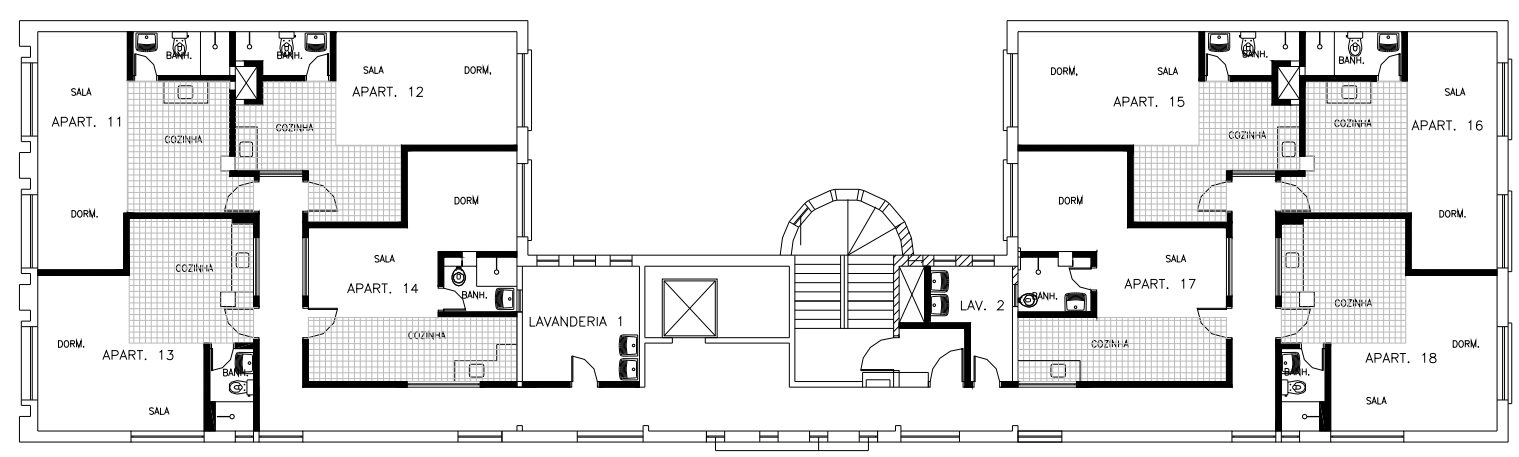

Figura 4.14 Planta do pavimento tipo do edifício Labor. Fonte: Integra

\subsubsection{Aspectos sociais da Gestão Pós-Ocupação}

A maioria dos atuais moradores do edifício Labor fez parte de um movimento de luta por moradia no centro (MSTC) e participou da ocupação do edifício em 1999. Este envolvimento gerou um relacionamento amistoso entre os moradores, o que facilitou as relações de vizinhança no edifício.

A gestão condominial terceirizada é realizada pela Administradora Acessional e acompanhada por um conselho fiscal formado por moradores.

De acordo com os arrendatários, não houve Trabalho Técnico Social no edifício por parte da CEF, entretanto, o bom relacionamento entre eles e a atuação das lideranças do movimento, foram suficientes para substituir este trabalho.

O relacionamento é considerado muito bom e os problemas sociais são praticamente inexistentes. A rotatividade de moradores é muito baixa, o que facilita mais o relacionamento.

De acordo com um morador, "... aqui todo mundo se conhece. Somos muito rigorosos com as pessoas e as coisas que fazem aqui. Por exemplo, qualquer probleminha com os jovens, batemos na porta da casa do indivíduo e falamos com os pais para que seja resolvido o quanto antes". 
Uma ação tomada pelos arrendatários foi a instalação de câmeras em toda a área comum do prédio a fim de controlar qualquer ato que prejudique os demais.

De acordo com uma moradora, "Nós é que tomamos conta destes problemas sociais. Se não fizessemos isso, já teriamos sérios problemas aqui..."

De acordo com levantamento da CEF, logo após a mudança, um problema foi identificado relacionado ao furto de fiação elétrica e antena. Porém, os próprios moradores conversaram entre si e conseguiram resolvê-lo.

Em pesquisa realizada pelo IPT ${ }^{55}$, Sanches (2008) aponta que a opinião dos moradores do edifício Labor com relação ao tipo de gestão condominial empregada pelo programa é positiva. Outros aspectos elencados na pesquisa, relacionados tanto ao condomínio quanto aos moradores, foram selecionados conforme tabela a seguir (Tabela 4.10):

${ }^{55}$ Os dados coletados na pesquisa foram obtidos através de entrevistas nos edifícios estudados adotando o seguinte critério: empreendimentos com menos de 50 unidades $-15 \%$ de entrevistas (do número de unidades); entre 51 e $100-10 \%$ de entrevistas; maior que $101-5 \%$ de entrevistas. 
Tabela 4.10 Dados gerais da gestão do edifício Labor.

\section{Edifício Labor}

Avaliação da gestão condominial empregada:

\begin{tabular}{lc}
\hline Ótimo & $18 \%$ \\
\hline Bom & $64 \%$ \\
\hline Razoável & $9 \%$ \\
\hline Péssimo & $9 \%$ \\
\hline
\end{tabular}

O que destaca de bom no condomínio?

Vizinhança

O que destaca de ruim no condomínio?

Conflitos

Sua vida melhorou após a mudança para o edifício?

\begin{tabular}{lc}
\hline Sim & $100 \%$ \\
\hline Não & $0 \%$
\end{tabular}

Em qual aspecto considera que sua vida melhorou?

Auto-estima

Qual o tipo de trabalho que realiza atualmente?

\begin{tabular}{ll}
\hline Formal & $55 \%$ \\
\hline Informal & $45 \%$ \\
\hline
\end{tabular}

Quantas pessoas moram no apartamento?

3

Qual a renda familiar mensal?

\begin{tabular}{ll}
\hline Até 3 s.m. & $36 \%$ \\
\hline Até 6 s.m. & $55 \%$ \\
\hline Até 10 s.m. & $0 \%$ \\
\hline$>10$ s.m. & $9 \%$
\end{tabular}

Há quanto tempo mora no edifício?

\begin{tabular}{lc}
\hline Até 1 ano & $0 \%$ \\
\hline 1 a 2 anos & $55 \%$ \\
\hline 2 a 4 anos & $45 \%$ \\
\hline$>4$ anos & $0 \%$ \\
\hline Qual a forma de moradia anterior? & $55 \%$ \\
\hline Aluguel & $18 \%$ \\
\hline Cortiço & $0 \%$ \\
\hline Favela & $18 \%$ \\
\hline Ocupação & $9 \%$
\end{tabular}

Fonte: SANCHES, 2008.

Os dados coletados indicam que somente $18 \%$ dos moradores entrevistados não estão satisfeitos com a gestão condominial empregada no prédio. Outros dados de grande relevância são os que indicam que quase a metade das famílias mora no 
edifício há quase quatro anos e $100 \%$ das pessoas consideram que a vida melhorou após a mudança para o edifício, sendo a auto-estima o principal ponto de melhora.

É importante frisar que, de acordo com visita realizada no edifício, foi possível notar que as áreas comuns são bastante cuidadas e se sobressaem aos outros prédios com relação à limpeza e organização (Foto 4.19).
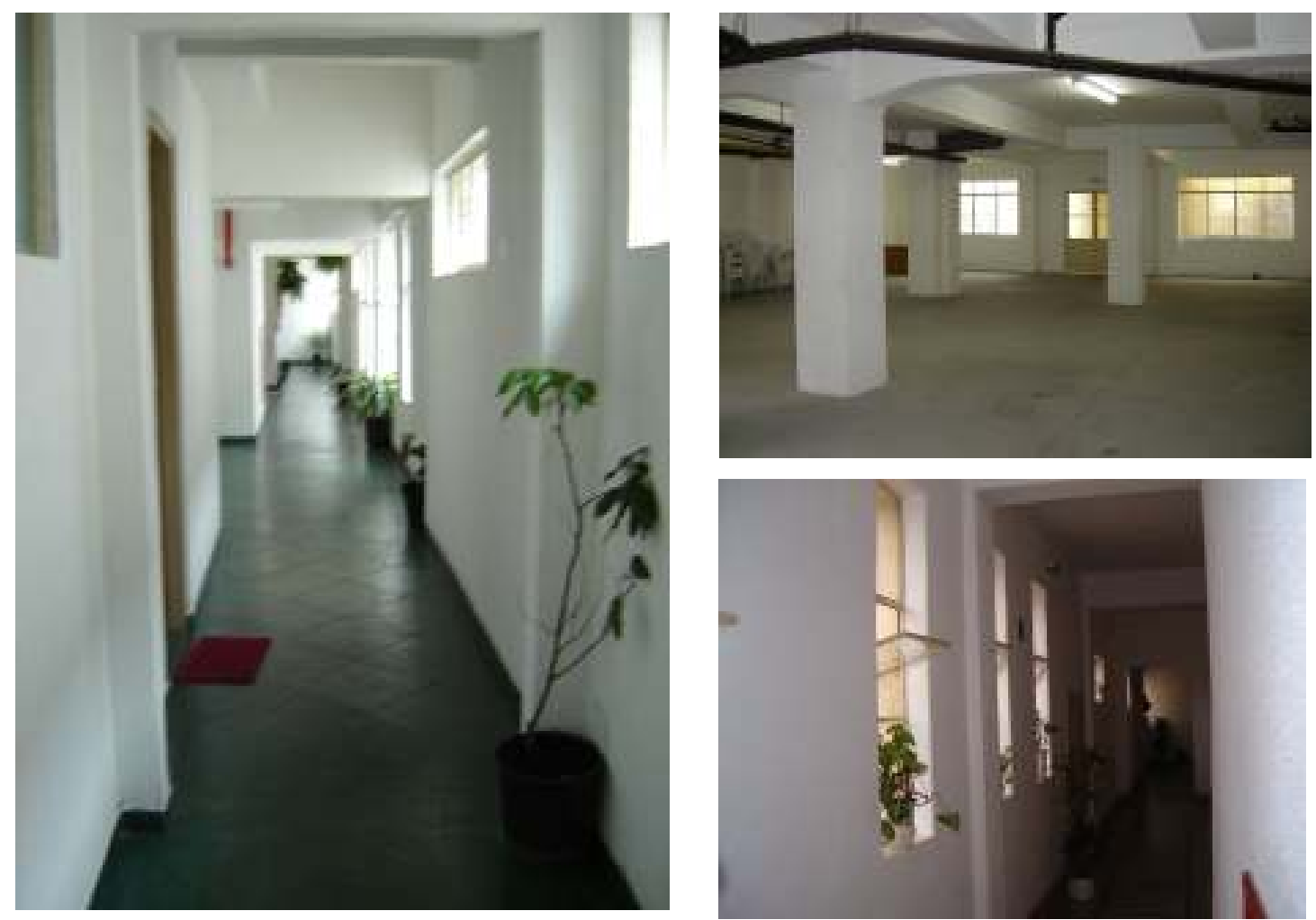

Foto 4.19 Imagens das áreas comuns internas do edifício Labor.

\subsubsection{Aspectos econômicos da Gestão Pós-Ocupação}

Os maiores gastos registrados no condomínio estão relacionados à manutenção dos elevadores, que desde o momento da mudança não funcionam corretamente.

A taxa de condomínio paga mensalmente pelos arrendatários, atualmente, é de $R \$ 70$ além dos $R \$ 15$ do fundo de reforma para os elevadores, totalizando $R \$$ 95. Já a taxa de arrendamento está em aproximadamente $R \$ 240$.

A renda média dos moradores do edifício é de aproximadamente quatro salários mínimos, o equivalente a $R \$ 1,7$ mil. Os gastos mensais fixos com 0 apartamento são de aproximadamente $\mathrm{R} \$ 350$ entre arrendamento e condomínio. 
A inadimplência da taxa de condomínio é a mais baixa entre os edifícios estudados, ficando em aproximadamente $7 \%$.

\subsubsection{Aspectos físico-construtivos da Gestão Pós-Ocupação}

De acordo com os moradores, desde o momento da mudança o prédio já apresentava diversos problemas. O principal, e que persiste até hoje, é o mal funcionamento dos elevadores. "Tivemos que fazer a mudança no colo. Um elevador nunca funcionou e o outro quebra quase todos os dias" diz uma moradora entrevistada.

Em levantamento realizado pela CEF, foram apontados problemas de infiltração nas unidades do mezanino e no telhado, problemas com o elevador recuperado e roubos de fiação elétrica (MONICE, 2006).

Conforme gráfico apresentado a seguir (Gráfico 4.3), de acordo com dados levantados ${ }^{56}$ pelo Projeto REABILITA (2007), nas unidades habitacionais, o principal problema identificado, conforme consta nos dados divulgados pela CEF, são as esquadrias, onde $61 \%$ está relacionado às janelas que emperram para a abertura. $A$ hidráulica apresenta um número significativo de problemas, mas que na grande maioria está relacionada à falta de manutenção de sifões e ralos. Outro problema encontrado está em relação ao sistema elétrico, mas que se relaciona ao assentamento de caixas de luz - no caso do apartamento - e nos pontos de iluminação - no caso da área comum. Finalmente, o último problema apontado pelos moradores é com o revestimento, pois os tacos recuperados se descolam ao longo do tempo.

\footnotetext{
${ }^{56}$ Os levantamentos foram realizados utilizando dados fornecidos pela CEF. Estes dados são referentes às reclamações feitas pelos moradores no período entre 2004 e 2006.
} 


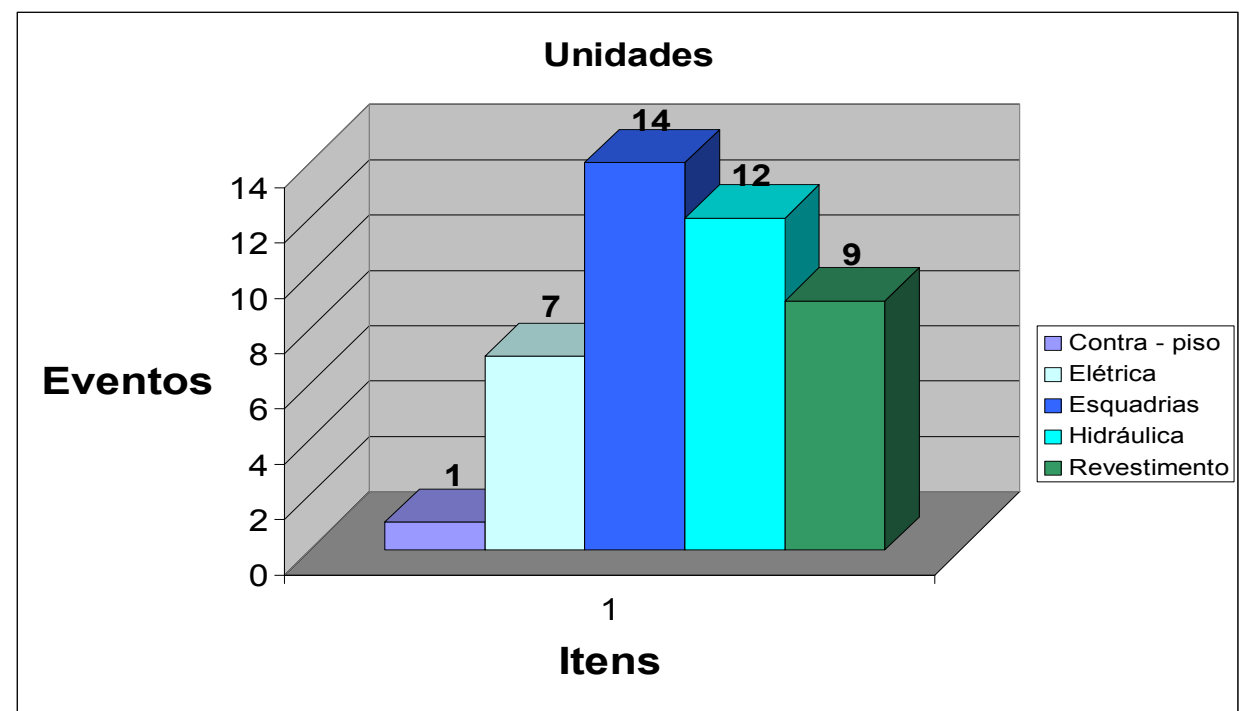

Gráfico 4.3 Problemas das unidades habitacionais por número de solicitações no edifício Labor.

Fonte: REABILITA, 2007.

Nas áreas comuns, conforme gráfico a seguir (Gráfico 4.4) os problemas com as esquadrias se repetem e as mesmas emperram na abertura. Os equipamentos de segurança também são alvo de reclamações, onde as portas corta-fogo emperram ao abrir. Outro ponto relevante é a presença de vazamentos na captação de águas pluviais e o entupimento de ralos. Finalmente, outro ponto é a impermeabilização de algumas lajes.

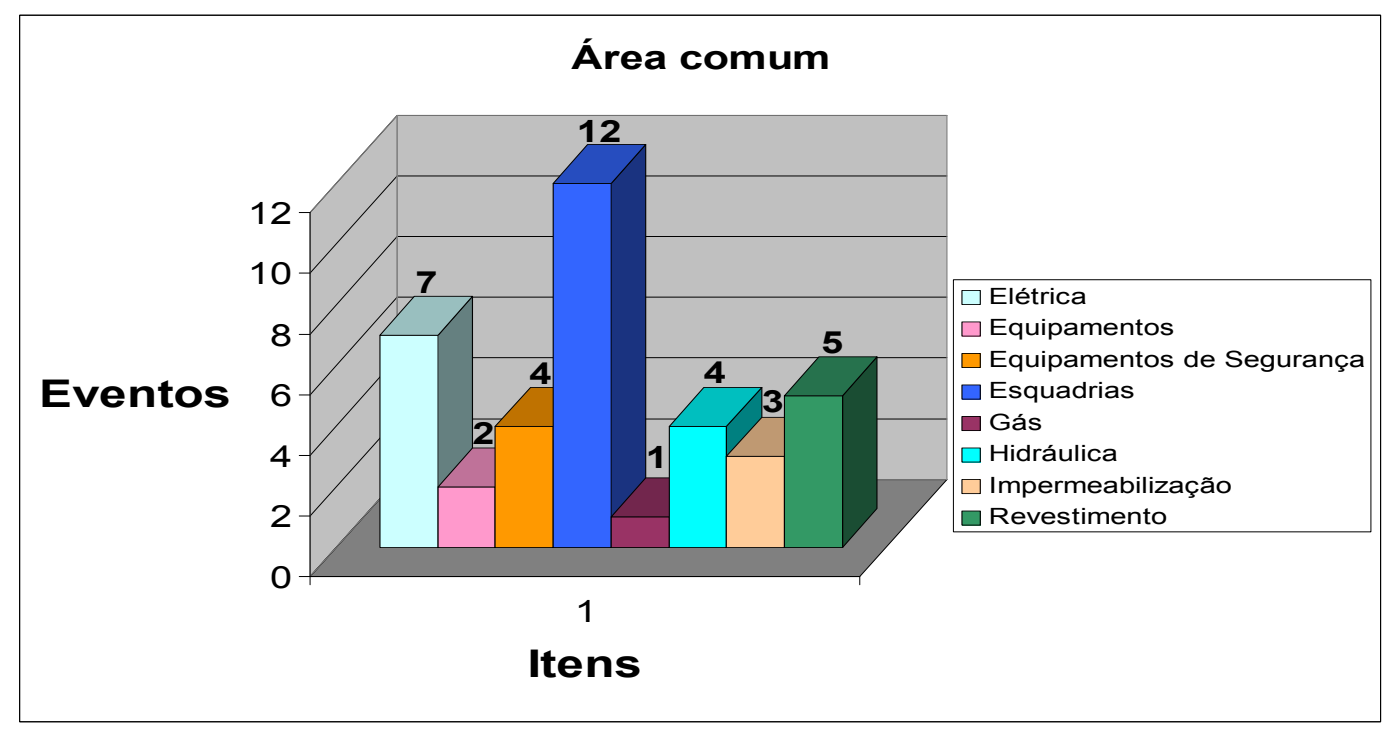

Gráfico 4.4 Problemas nas áreas comuns por número de solicitações no edifício Labor. Fonte: REABILITA, 2007. 


\subsubsection{Aspectos arquitetônicos e urbanísticos da Gestão Pós-Ocupação}

As tipologias das unidades habitacionais possuem em média $30 \mathrm{~m}^{2}$ sendo a maioria quitinetes e 3 apartamentos adaptados para moradores com mobilidade reduzida, localizados no térreo.

Além da edificação principal, o Ed. Labor conta com um anexo que ainda não está sendo utilizado e que poderá servir de espaço para atividades culturais, como cursos e aulas. Esse anexo está equipado com salas, cozinha comunitária e banheiros masculino e feminino. Foram construídos no subsolo e na parte posterior do edifício, equipamentos comunitários como: depósito de lixo, abrigo de gás, salão de festas e áreas de lazer condominial.

O edifício conta ainda com lavanderias coletivas nos pavimentos que atendem, cada uma, quatro unidades habitacionais. Entretanto, as lavanderias são apontadas como problemáticas pelos moradores, pois não existe um controle do uso e o gasto de água acaba sendo muito elevado.

Quando perguntados sobre o edifício e as unidades habitacionais, os moradores demonstram grande satisfação e orgulho. A localização privilegiada no centro da cidade demonstra ser a característica mais apreciada pelos moradores. 


\section{Análise da pesquisa de campo}

A pesquisa de campo indica que os cinco prédios selecionados para análise apresentam pontos positivos e negativos na gestão pós-ocupação.

Dentre os aspectos positivos levantados, a pesquisa evidenciou o fato de os moradores pertencerem a um movimento de luta por moradia antes da mudança para o prédio, o que fez com que as relações de vizinhança fossem beneficiadas devido ao sentimento de união desenvolvido no período das ocupações. A existência de uma liderança, muitas vezes moradora do edifício, mantém o sentimento e as características do grupo, o que não ocorre em prédios nos quais os moradores se conhecem somente após a mudança.

Outro fator que caracteriza positivamente os edifícios reabilitados e seus moradores é a localização privilegiada na cidade. A proximidade com os locais de trabalho e a facilidade de acesso são pontos freqüentemente mencionados nos levantamentos.

Além disso, foi possível notar que, mesmo com problemas, os moradores possuem bastante orgulho dos prédios, principalmente por estarem inseridos na malha urbana da cidade.

Dentre os aspectos negativos da gestão dos edifícios reabilitados estudados, podemos destacar:

- Problemas sociais: Furtos, vandalismo nas áreas comuns e presença de grupos ilícitos nos prédios.

- Problemas financeiros: Dificuldade de pagamento da taxa condominial e de arrendamento pelos moradores.

- Problemas construtivos: Problemas técnicos relacionados aos elevadores, unidades habitacionais e áreas comuns desde o momento da entrega.

- Problemas administrativos: Dificuldade na resolução dos problemas existentes nos edifícios. 
Cabe, portanto, responder a duas questões que envolvem o objetivo do trabalho: indicar as razões que desencadearam os problemas levantados na gestão pós-ocupação dos edifícios estudados; e apontar as possíveis alternativas para minimizar as dificuldades tanto dos casos pesquisados, quanto de futuros projetos de reabilitação.

\subsection{Razões que desencadearam problemas na gestão pós- ocupação dos edifícios}

Nos cinco edifícios estudados foram encontrados problemas sociais na gestão pós-ocupação. Furtos de extintores, de iluminação de emergência e da fiação elétrica das áreas comuns foram detectados em todos os prédios. Alguns edifícios, entretanto, apresentaram problemas sociais ainda mais graves, como brigas entre moradores, vandalismo, presença de tráfico de drogas, furtos nos apartamentos, medo de morar por parte dos moradores, entre outros.

Muitas podem ser as razões para os fatos encontrados. Mas alguns aspectos específicos podem ter colaborado para os problemas observados acima.

O primeiro aspecto evidenciado através da pesquisa é a falta de um trabalho social contínuo junto às famílias moradoras.

O trabalho social nos programas de habitação de interesse social deve ser sistemático, contínuo e interdisciplinar para obter eficácia e efetividade em termos de apropriação do território e da moradia (IEE, 2006). Deve ser mais amplo do que o chamado acompanhamento social, englobando várias dimensões complementares, como o planejamento das ações, articulação e integração com o programa, trabalho direto com a população no território, supervisão, monitoramento e avaliação (IEE, 2006).

Deve servir como um acordo transparente que define regras e critérios relativos às responsabilidades e atribuições de cada componente do sistema, ficando claros os novos direitos e deveres dos moradores na vida em condomínio, bem como o papel da administradora e da CEF dentro do programa de arrendamento. Mesmo com a característica dos moradores dos edifícios reabilitados, que já fazem parte de um grupo formado pelos movimentos de moradia, os 
arrendatários precisam entender as novas regras deste modo de morar. De acordo com Contreras (2001), é fundamental para a vida em condomínio que, além de existirem as boas relações de vizinhança, se exercite o direito e a obrigação de zelar pelo que é de todos.

Porém, o trabalho realizado pela CEF possui duração de seis meses, contados a partir da entrada dos moradores. Esta limitação de tempo dos trabalhos pode prejudicar os resultados dos mesmos, pois a rotatividade de moradores nestes prédios em geral é alta e o trabalho acaba atingindo somente a população que mudou para o edifício até seis meses depois da entrega das unidades.

Dos cinco edifícios estudados, somente dois tiveram o TTS obrigatório realizado pela CEF (Fernão Salles e Riskallah Jorge). No edifício Riskallah Jorge, em que a rotatividade é alta, os problemas sociais são grandes e considerados graves pela própria CEF, o que pode indicar que os arrendatários que se mudaram para o edifício após o período de realização do trabalho social não tiveram, nenhum tipo de acompanhamento.

Em geral, a rotatividade de moradores nos edifícios pode estar relacionada a diversos fatores, como a dificuldade em arcar com o pagamento da taxa condominial e do arrendamento, a insatisfação com a unidade habitacional, problemas de relacionamento com a vizinhança, além da dificuldade de adaptação com os direitos e deveres da vida em condomínio.

No edifício Fernão Salles, em que a rotatividade de moradores é baixa, as relações sociais em geral são consideradas positivas e os problemas sociais encontrados são poucos, o que pode significar que a maioria das famílias moradoras participou deste trabalho de orientação feito pelos técnicos sociais contratados pela CEF.

Nos edifícios em que a rotatividade de famílias é baixa, os próprios moradores, que se conhecem desde o período que participavam do movimento de moradia, passam a ser os "zeladores" das relações de vizinhança e da conservação das áreas comuns. No edifício Labor, por exemplo, que de acordo com a pesquisa realizada não possui problemas sociais considerados graves, os moradores continuam unidos e se preocupam em zelar pelas relações entre eles. Em depoimento coletado na pesquisa, um morador afirma que “... aqui todo mundo se conhece. Somos muito rigorosos com as pessoas e as coisas que fazem aqui. Por 
exemplo, qualquer probleminha com os jovens, batemos na porta da casa do indivíduo e falamos com os pais para que seja resolvido o quanto antes", diz o morador.

O TTS, muito importante e necessário, deve ser, portanto, contínuo, atendendo a todos os moradores que ingressarem no edifício, garantindo que toda população seja orientada.

O segundo aspecto relacionado aos problemas sociais nos prédios é a falta de controle do órgão promotor sobre os edifícios e moradores durante a pósocupação. Em alguns casos, problemas sociais como atos de vandalismo e furtos nas áreas comuns, bem como ocorrências de venda e aluguel das unidades arrendadas acontecem desde o período da mudança. Os moradores afirmam que nada é feito contra isso, ou seja, nenhuma ação de punição, ainda que previsto em contrato, é realizada. Esta falta de controle pode demonstrar desorganização e até mesmo descaso da CEF para com os arrendatários, dificultando ainda mais a relação existente entre ambos.

O terceiro aspecto que pôde ser evidenciado é a falta da sensação de pertencimento existente entre os moradores. Por não serem proprietários do imóvel, e sim arrendatários, algumas pessoas apresentam um sentimento de indiferença e até mesmo revolta com o todo, causando vandalismo, furtos, entre outras coisas. A ausência desta sensação de pertencimento do morador para com o edifício e a unidade habitacional pode refletir diretamente no tratamento dado ao local. De acordo com Amaral (2006) "a sensação de pertencimento significa que precisamos nos sentir como pertencentes a tal lugar e ao mesmo tempo sentir que esse tal lugar nos pertence. Assim, acreditamos que podemos interferir e, mais do que tudo, que vale a pena interferir na rotina e nos rumos desse tal lugar".

Em relação aos problemas financeiros dos moradores, as altas taxas de inadimplência na maioria dos edifícios podem ser reflexos de características específicas desta população.

A inconstância do emprego e, conseqüentemente, a inconstância da renda mensal das famílias, pode refletir diretamente na falta de pagamento das responsabilidades firmadas no condomínio e com o arrendamento da unidade. $\mathrm{O}$ desemprego é constante, pois a demanda para os programas de habitação social é 
focada em famílias inseridas socialmente em serviços de curta duração, pequeno comércio de rua, setores mal pagos, entre outros.

O Programa de Arrendamento Residencial (PAR) da CEF é destinado a famílias com renda mensal entre três e seis salários mínimos. Entretanto, as famílias que possuem a menor renda permitida pelo programa, três salários mínimos, acabam sendo as mais prejudicadas, pois os gastos com o condomínio e arrendamento podem chegar a $1 / 3$ do valor total da renda mensal. De acordo com o momento e as necessidades da família, pagar estas taxas passa a ser secundário frente a outras prioridades, como saúde e alimentação.

Outro fator relacionado às dificuldades de pagamento das taxas que deve ser destacado é o constante acréscimo de valor nas taxas condominiais devido aos rateios de custos que os condôminos fazem para viabilizar alguns reparos necessários e urgentes no edifício. Estes custos extra não estão previstos no orçamento mensal dos arrendatários, o que acaba muitas vezes inviabilizando estes pagamentos e prejudicando o orçamento mensal da família.

Cabe ressaltar que nos estudos realizados também foram detectados casos de falta de pagamento por opção e por sensação de injustiça. Em alguns casos, os moradores, mesmo tendo condições financeiras, simplesmente optam por não pagar as taxas. A opção pode ser momentânea, em que se faz necessário priorizar outros investimentos, porém, em outros casos, a opção é permanente, ora justificada pela falta de organização da CEF em cobrar estes moradores, ora pela possibilidade de se fazer um acordo posteriormente. Em conseqüência, os moradores adimplentes acabam sentindo-se injustiçados com esta situação e, mesmo tendo condições financeiras, também deixam de pagar as taxas, formando uma reação em cadeia.

Já os constantes problemas construtivos existentes nas unidades habitacionais e áreas comuns podem ser ocasionados por fatores relacionados aos equipamentos reformados e materiais empregados na obra de reabilitação.

O maior vilão dos problemas construtivos existentes nos edifícios são os elevadores. Por serem reabilitações, os prédios antes da reforma já possuíam elevadores instalados para o antigo uso, mas que estavam em desuso e muitas vezes quebrados. Entretanto, devido ao custo, os equipamentos não foram trocados por novos e sim reformados e adaptados para o uso atual. 
Dos cinco edifícios estudados, todos apresentaram problemas relacionados com a manutenção dos elevadores. Em alguns casos os equipamentos não funcionam desde o momento da mudança,e estavam parados até a data desta pesquisa. De acordo com Marques de Jesus (2008), diversos problemas foram identificados pela CEF durante a operação destes elevadores que não foram substituídos por novos. Sendo assim, caso seja realmente necessário, o aproveitamento dos elevadores deve ser minuciosamente estudado, de forma a evitar possíveis problemas após a entrega do empreendimento, o que, de fato, também poderá gerar custos significativos de manutenção. Nas análises de novos projetos de reabilitação, a CEF não está mais admitindo o aproveitamento dos elevadores antigos, solicitando a substituição destes por novos.

Outros tipos de reclamações relacionadas aos problemas construtivos são muito constantes nos edifícios estudados. De acordo com levantamento feito pelo Projeto REABILITA (2007), os maiores índices de reclamação são referentes ao mau funcionamento das esquadrias e problemas nas instalações hidráulicas. Entretanto, os custos gerados por esta manutenção não estão previstos no programa e acabam sendo empurrados para os moradores, que em geral não têm condições financeiras de arcar com tamanha despesa. Em alguns casos os moradores fazem um rateio para resolver o problema, porém, dependendo do tamanho do custo, os moradores não conseguem pagar e o problema acaba sendo permanente no edifício, prejudicando única e exclusivamente os moradores.

A CEF, quando perguntada sobre estes custos de manutenção da pósocupação, alega que cada caso é avaliado separadamente, sendo que de acordo com o tipo do problema aciona a construtora que deverá resolver. Caso entenda que o problema é do condomínio, não se responsabiliza pelos custos.

A falta de previsão e planejamento desses gastos da pós-ocupação põe em risco a sustentabilidade do empreendimento e cria um processo burocrático relacionado à gestão condominial e sua operacionalização (REABILITA, 2007). Conforme citado no capítulo três desta dissertação, a fase de uso e ocupação engloba custos de manutenção da unidade e do edifício como um todo. Estudos realizados em diversos países para diferentes tipos de edifícios demonstram que os custos anuais envolvidos na operação e manutenção das edificações em uso variam entre $1 \%$ e $2 \%$ do seu custo inicial, que envolve as fases de viabilização, projeto e 
construção (ABNT, 1999; JOHN, 1988; LEE, 1988). Este valor pode parecer pequeno, porém, acumulado ao longo da vida útil do edifício, chega a ser equivalente ou mesmo superior ao seu custo de construção.

Um programa habitacional voltado para população com renda mensal de três a seis salários mínimos não deve partir do pressuposto de que os moradores terão condições de arcar com todos os gastos gerados pela operação e manutenção de um edifício. Esta visão garante somente que a sustentabilidade social, econômica e física destes prédios estará comprometida desde o momento da concepção do programa.

Outro fator a ser destacado é a falta de fornecimento de projetos e manuais de uso necessários aos usuários. Os moradores dos cinco edifícios estudados não receberam as plantas e manuais de uso e operação das unidades habitacionais e das áreas comuns, o que dificulta qualquer ação de uso e manutenção. O uso incorreto dos sistemas e equipamentos de um edifício por falta de informação também pode causar uma série de danos e, conseqüentemente, uma série de gastos extras para o condomínio.

Além dos aspectos sociais e financeiros dos moradores e aspectos físicos dos edifícios, a pesquisa evidencia que um dos grandes problemas da gestão pósocupação dos prédios está diretamente relacionado à falta de administração. Foram apresentados problemas desde o momento da mudança, demonstrando despreparo e falta de planejamento para o período da gestão pós-ocupação por parte da CEF, órgão promotor do programa habitacional e que deveria ser responsável por esta administração.

Em todos os prédios estudados, no momento da mudança dos arrendatários, por exemplo, as unidades habitacionais e as áreas comuns não estavam totalmente finalizadas e apresentavam uma variedade de problemas ainda sem solução. No edifício Riskallah Jorge, os moradores tiveram que se mudar para o prédio mesmo estando sem água e luz. Nos edifícios Labor e Olga Benário, o elevador ainda não funcionava e o transporte dos móveis e pertences dos moradores foi feito pela escada de incêndio. No edifício Maria Paula, logo após a mudança, os moradores souberam que teriam que arcar com uma dívida de condomínio de aproximadamente $\mathrm{R} \$ 50$ mil. 
Nos edifícios reabilitados do PAR, o planejamento realizado pela CEF para o período da pós-ocupação nos prédios se resume a dois canais: as empresas administradoras de condomínios e o Trabalho Técnico Social (TTS).

O papel das empresas administradoras nesta modalidade de gestão é o de assumir a responsabilidade pela execução das questões burocráticas, tais como controle de pessoal, emissão e distribuição dos boletos e cartas, recrutamento de funcionários, elaboração e acompanhamento da previsão orçamentária, cobrança administrativa de devedores, alteração da Convenção de Condomínio, entre outras. Além disso, no programa de arrendamento, as empresas administradoras de condomínios também são os síndicos dos prédios, direito transferido pela CEF.

Já o TTS ocorre por seis meses após a entrada dos moradores e é realizado por empresa terceirizada escolhida por licitação.

Sendo assim, no período de uso e operação dos edifícios, a empresa de administração passa a ser o único canal para resolução dos problemas dos arrendatários, conforme fluxo apresentado a seguir (Figura 5.1):

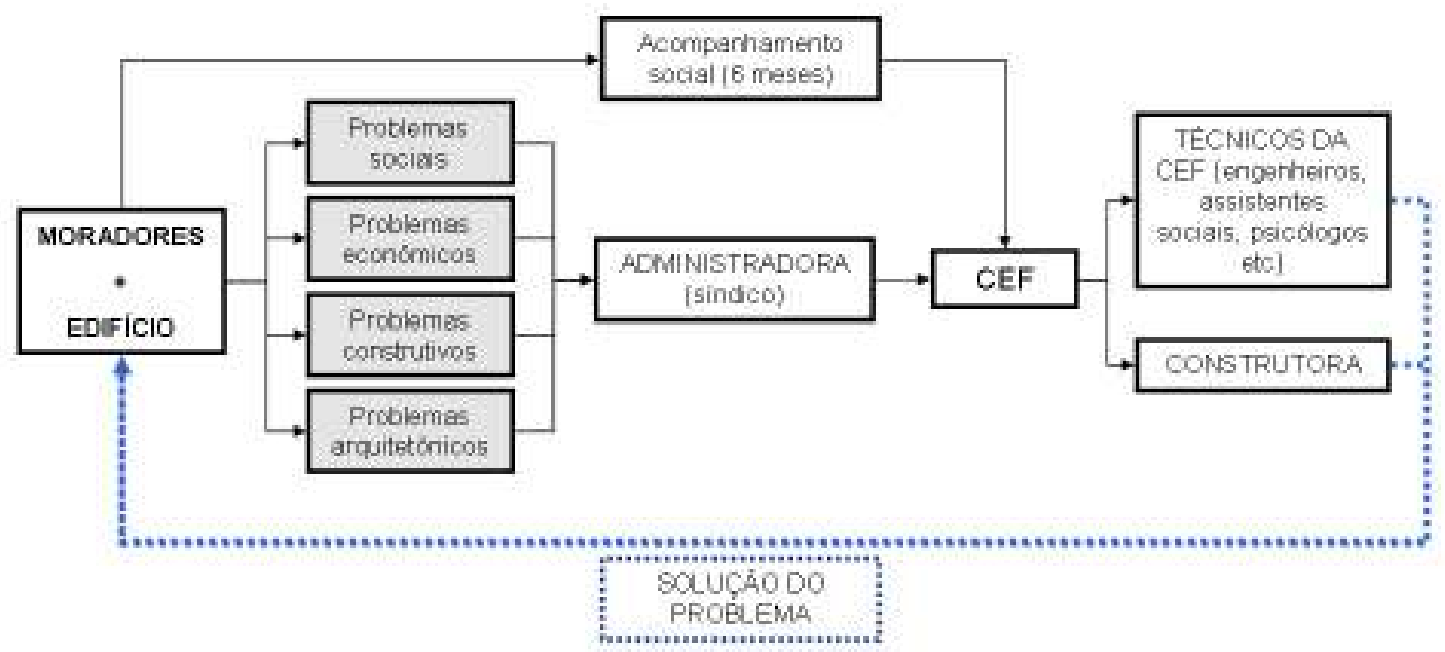

Figura 5.1 Fluxo ilustrativo representando estrutura atual da gestão dos edifícios reabilitados do PAR.

Caso os moradores tenham algum tipo de problema no edifício, encaminham uma solicitação para a administradora, que, como representante do prédio, a reencaminha para a CEF. A ação tomada pela CEF é feita por meio de seus técnicos (engenheiros, arquitetos, psicólogos) ou pela construtora responsável, caso o problema seja construtivo. 
Entretanto, conforme levantado na pesquisa, a dificuldade e morosidade no processo de resolução de problemas existentes no edifício é mais uma razão dos problemas encontrados na pós-ocupação dos prédios, uma vez que os procedimentos aplicados não estão sendo eficientes e os responsáveis não estão conseguindo resolver as questões necessárias em tempo hábil.

A intermediação dos problemas entre a CEF e os arrendatários é muitas vezes prejudicada pela dificuldade de comunicação entre os moradores e a empresa. Como administram diversos edifícios, em muitos casos não conseguem encaminhar todas as questões pendentes de cada prédio, prejudicando ainda mais o processo. Além disso, quando conseguem encaminhar os problemas dos edifícios para a CEF, sejam eles sociais, físicos ou financeiros, a demora para resolução é tão grande que os próprios moradores preferem resolver sozinhos, arcando com as despesas necessárias.

Enfim, é possível elencar inúmeros fatores que desencadeiam problemas na gestão de um edifício reabilitado. Cabe agora buscar alternativas que minimizem estes problemas na gestão pós-ocupação.

\subsection{Alternativas visando à minimização dos problemas na gestão pós-ocupação em edifícios reabilitados pelo PAR}

A maioria das razões para os problemas na gestão pós-ocupação apontadas acima podem ser consideradas fruto da falta de planejamento do programa habitacional para a fase de uso dos edifícios. Aspectos como a falta de um trabalho social contínuo, ausência da sensação de pertencimento dos moradores com os prédios, falta de pagamento das taxas por opção e por sensação de injustiça, além da dificuldade e morosidade no processo de resolução dos problemas são alguns exemplos que evidenciam a falta de um trabalho nesta fase.

Dentro de uma perspectiva ampla, o período da gestão pós-ocupação dos prédios voltados para HIS deve ser planejado e estruturado desde o momento da concepção do programa em que se insere, a fim de garantir a sustentabilidade dos moradores e dos edifícios. Cabe ao órgão promotor destas unidades entender o 
processo como um todo, e planejar uma estrutura, seja interna ou externa, capaz de gerenciar e manter a população e os prédios.

Uma alternativa que busca minimizar os problemas existentes na fase de uso e ocupação dos edifícios reabilitados voltados para habitação de interesse social é o redesenho da estrutura do programa de arrendamento residencial, feito de forma que garanta que a atuação do órgão promotor não acabe no momento da entrega das chaves mas sim, que haja sempre um grande gerenciamento, responsável por estruturar os edifícios e as necessidades de seus moradores.

Este redesenho do programa deve ter como objetivo planejar a gestão pósocupação dos prédios, garantindo a permanência dos moradores e a manutenção do edifício.

É necessário que seja planejado um trabalho social complexo, realizado por equipe multidisciplinar e que vá além do acompanhamento social realizado atualmente no programa. Deve ser um serviço social que englobe diversas dimensões complementares, como o planejamento das ações, supervisão, monitoramento e avaliação, tendo como objetivo principal obter maior controle do programa sobre os edifícios e seus moradores, por meio deste trabalho contínuo, iniciado logo após a escolha da demanda, a fim de garantir maior tempo de acompanhamento.

Este trabalho deve gerenciar as relações de vizinhança existentes no condomínio, instruindo a população moradora com o objetivo de evitar a ocorrência de furtos, brigas e vandalismo nas áreas comuns. O acompanhamento deve ser realizado com todas as famílias que entrarem no programa, em qualquer período, garantindo que, mesmo com a rotatividade de famílias no prédio, o trabalho de orientação seja realizado.

Deve englobar também um acompanhamento com as famílias relacionado à situação de emprego e renda mensal, buscando inserir estas pessoas em programas públicos de capacitação e de emprego disponíveis, a fim de garantir a renda familiar e conseqüentemente a possibilidade de pagamento dos compromissos com 0 condomínio e o arrendamento.

O trabalho deve ser iniciado no período anterior a mudança, uma vez que é importante a realização de uma preparação para a chegada dos moradores, viabilizando os procedimentos necessários para as famílias. Deve ser levantado o 
histórico e a origem da demanda para que seja elaborado um trabalho social específico e que funcione para aquela população, articulando contatos institucionais para atendimento à demanda de serviços sociais e de infra-estrutura urbana no novo território.

Após esta preparação, o trabalho poderá ser iniciado com as famílias antes mesmo da transferência para o prédio, capacitando a população para este novo modo de vida.

No momento da mudança, é importante que as famílias passem por um trabalho que tanto organize a distribuição das unidades e esclareça dúvidas sobre o funcionamento e utilização dos sistemas de abastecimento de água, luz e gás, quanto promova uma discussão inicial sobre as regras de convivência e de uso, manutenção e conservação das unidades habitacionais, dos equipamentos e dos espaços coletivos.

Após a mudança, o trabalho deverá ser ampliado a fim de garantir a permanência daquela população, seja no edifício atual ou em outro, desde que este também faça parte do programa e que efetive as necessidades da família. $O$ trabalho pós-mudança pode englobar desde esclarecimentos sobre as relações de vizinhança até ajuda na busca por oportunidades de emprego para aquelas famílias que estão inadimplentes nas taxas condominiais, evitando assim prejudicar os outros condôminos. Deve ser realizada a troca de arrendatários que não conseguirem arcar com as parcelas de um condomínio para outro edifício que tenha taxas mais baixas, viabilizando a permanência da família e garantindo a sustentabilidade do programa.

Já com relação à manutenção dos edifícios, o redesenho do programa deve prever um fundo relacionado aos custos para a manutenção dos prédios. Devido à impossibilidade financeira dos moradores, que já são selecionados por possuírem uma renda mensal baixa, os custos relacionados à manutenção das áreas comuns do edifício e das unidades habitacionais devem estar previstos pela linha de financiamento do programa, a fim de garantir que os serviços de manutenção necessários ao longo do tempo, tais como manutenção de elevadores, pintura das fachadas, entre outros, sejam realizados. Além disso, esta previsão garante que não haja aumentos das taxas condominiais devido aos rateios realizados pelos condôminos para executar algum tipo de intervenção necessária no edifício. 
Como o programa é de arrendamento das unidades, ou seja, os arrendatários podem arrendar unidades residenciais com prestações mensais equivalentes a um aluguel, cabendo aos mesmos a opção de adquirir o bem arrendado com o pagamento do valor residual após 15 anos (MENEZES, 2008), após este período a CEF não será mais a proprietária de algumas das unidades ofertadas. Ou seja, após 15 anos da entrega, no mesmo edifício existirão unidades de propriedade dos moradores e unidades de propriedade da CEF, tendendo para que, futuramente, todas sejam de propriedade dos moradores.

Não caberia, portanto, o planejamento de uma gestão pós-ocupação realizada internamente pela CEF, pois futuramente esta poderá não estar mais envolvida no edifício.

Já as empresas administradoras de condomínio, devido às regras do PAR, estarão trabalhando com as famílias pelo menos até que a propriedade de todas as unidades habitacionais seja transferida aos moradores. Somente após este período, os até então arrendatários, agora proprietários, poderão escolher se querem ou não continuar com a gestão condominial terceirizada.

Sendo assim, as administradoras de condomínios podem vir a ser uma alternativa de agente operacionalizador desta gestão pós-ocupação nos edifícios reabilitados do PAR, pois mesmo após a saída da CEF dos prédios, a empresa poderá continuar o trabalho com os moradores.

Entretanto, para realizar esta gestão, será preciso que as administradoras reformulem seu escopo de atuação nos edifícios. A empresa passará a administrar não mais somente os aspectos burocráticos dos condomínios, mas sim todos os aspectos que envolvem questões sociais, financeiras, jurídicas, administrativas, psicológicas, técnicas etc.

A nova estrutura do serviço fornecido pela empresa administradora será ampla e englobará uma equipe multidisciplinar focada na manutenção dos moradores nos edifícios. Devido a este diferencial em seu escopo, estas "novas empresas" serão aqui chamadas de administradoras de condomínios sociais.

A CEF deve planejar a atuação das administradoras de condomínios sociais desde o início do programa, exigindo que, para participar da concorrência, a empresa possua esta nova proposta de gestão. 
A figura a seguir ilustra a nova proposta para as administradoras de condomínios, englobando os aspectos já realizados e os novos (Figura 5.2).

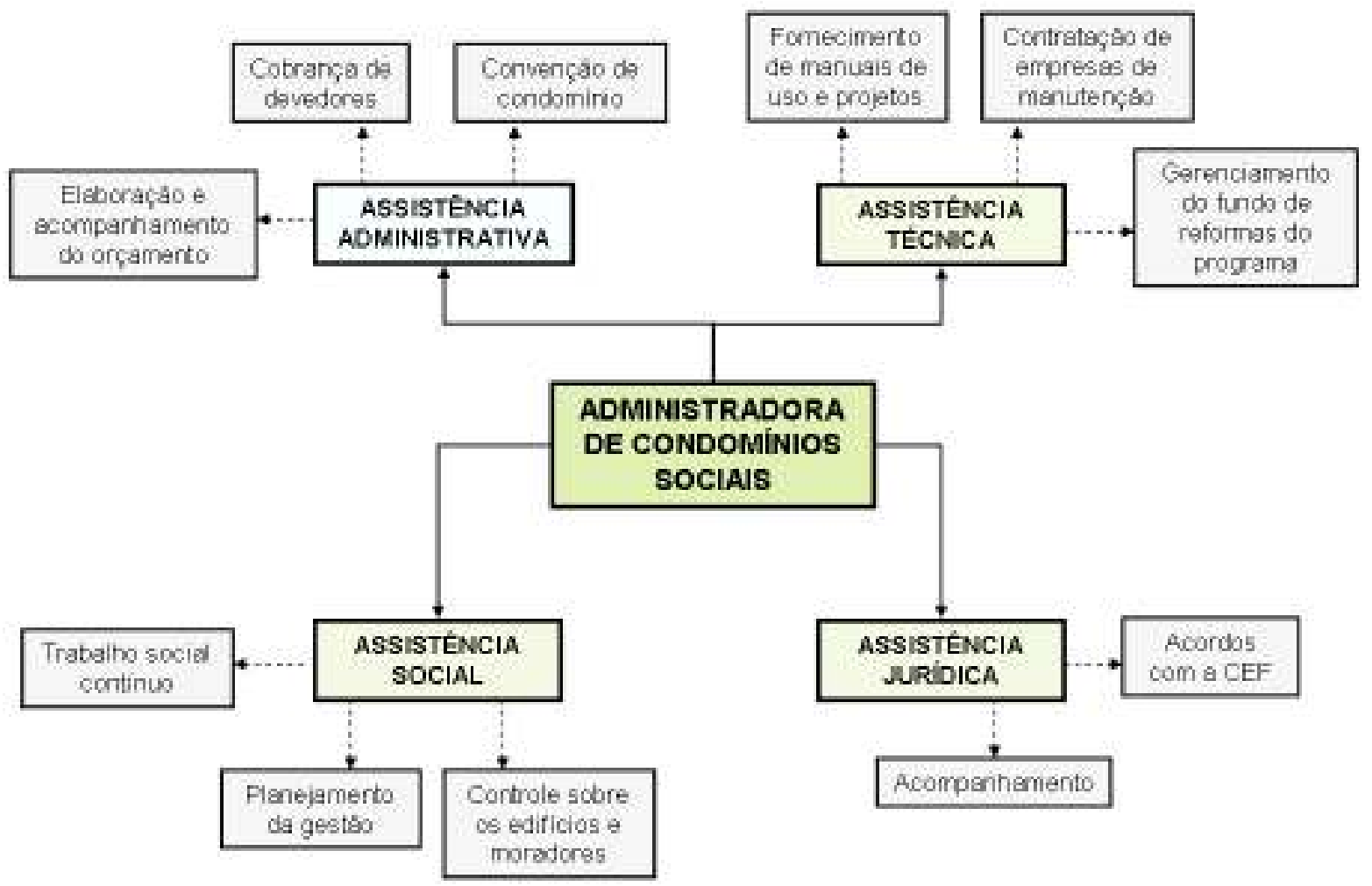

Figura 5.2 Fluxo ilustrativo representando as novas áreas de trabalho das administradoras de condomínios sociais.

Para os condomínios que optarem por uma gestão com autogestão, ou seja, em que os próprios condôminos se encarregam da administração do edifício, elegendo seus representantes por meio de uma comissão eleita de moradores, sem necessidade de contratação de empresa especializada ou profissional externo (SCHWARTZ, 2007), a opção de a administradora realizar a gestão pós-ocupação não existirá.

Sendo assim, caberá ao Poder Público, juntamente com o órgão promotor do programa habitacional, disponibilizar uma estrutura que operacionalize este trabalho com a população e os edifícios. Este acompanhamento social na pós-ocupação executado pelo Poder Público deve ser obrigatório aos edifícios de habitação social que optarem pela autogestão, para garantir a sustentabilidade do programa e evitar a possibilidade de o prédio passar a ser um problema social na cidade.

Além deste redesenho do programa, outras ações podem ser tomadas previamente a fim de interferir diretamente na fase de uso e ocupação dos edifícios. 
Ações realizadas na fase de viabilização do projeto de reabilitação podem trazer uma redução significativa das futuras taxas condominiais dos prédios. Entretanto, necessitam de um investimento inicial maior para serem viabilizadas.

Estudo realizado pela empresa Tishman Speyer do Brasil (BLANCO, 2008), apontou que $\mathrm{o}$ investimento em alguns processos construtivos e dispositivos tecnológicos, no momento da viabilização do projeto, pode trazer uma redução no custo da fase de uso e operação de unidades habitacionais. A pesquisa, focada para edifícios novos e com apartamentos de $120 \mathrm{~m}^{2}$, constatou que através de um incremento de $5 \%$ no custo da construção investido pela incorporadora, o futuro morador poderia ter uma redução de $\mathrm{R} \$ 3 / \mathrm{m}^{2}$ no custo mensal de operaçãa ${ }^{57}$.

Outro estudo, realizado pela administradora de condomínio Hubert em 50 condomínios residenciais, apontou que depois da implantação de sistemas simples, como a inclusão de medidores individuais de água e gás, foi identificada redução de $10 \%$ a $30 \%$ no valor do condomínio ${ }^{58}$.

Para os edifícios reabilitados, a inclusão de dispositivos tecnológicos e processos construtivos que reduzam futuros gastos pode ser mais difícil devido à necessidade de investimento inicial e de adaptações necessárias aos prédios já construídos. Entretanto, deve ser levada em consideração a proposta de realização de estudos comparativos para avaliação e possível viabilização de pelo menos alguns dos elementos que minimizam os custos da pós-ocupação nos condomínios, como os medidores individuais de água e gás.

Um dos itens de maior problema nos edifícios estudados são os elevadores reformados. De acordo com dados do Sindicato de Conservação, Manutenção, e Instalação de Elevadores do Estado de São Paulo (Seciesp), os elevadores são responsáveis por cerca de $70 \%$ do total da conta de luz de um prédio. Já os elevadores antigos gastam mais, pois utilizam a mesma quantidade de energia sem levar em conta a velocidade de uma viagem. Os sistemas atuais contam com variadores de tensão de freqüência, ou seja, consomem energia apenas para

\footnotetext{
${ }^{57}$ Como exemplo, a pesquisa aponta que para redução do consumo energético, foram considerados medidores individuais, lâmpadas PL, automação de elevadores e de iluminação, motores de freqüência variável para elevadores e bombas de aquecimento solar de água. Já para o racionamento de água, foram incluídos medidores individuais, chuveiros de baixo consumo, vaso sanitário de dupla descarga, reaproveitamento de águas de chuva (BLANCO, 2008).

${ }^{58}$ De acordo com a pesquisa, a opção por peças redutoras de vazão trouxe uma economia de $9 \%$ no consumo de água e a troca da parte interna das caixas acopladas de 16 litros por outras de 6 litros resultou na redução de $R \$ 1.200 /$ mês, com investimento inicial de $R \$ 2.800$ (BLANCO, 2008).
} 
transportar o número de pessoas que está dentro do elevador para os andares de destino. Isso pode representar uma economia de $30 \%$ a $40 \%$ nos gastos de energia elétrica.

Outra ação importante e que pode vir a resultar na diminuição dos custos de conservação dos edifícios é a participação da futura população moradora nas decisões do projeto. Em análise feita pelo projeto Reabilita (2007), a participação da demanda em alguns projetos resultou em soluções mais adequadas, gerando, inclusive, uma gestão condominial de melhor qualidade, uma vez que já havia sido estabelecida uma dinâmica entre o grupo. De acordo com Amaral (2006), “(...) o sentimento de pertencimento tem relação com a noção de participação. Na medida em que o grupo se sente ator da ação em curso, o que for sendo construído de forma participativa desenvolverá a co-responsabilidade, pertencendo os resultados a todos desse grupo, pois conterá um pouco de cada um".

Concluindo, os problemas na pós-ocupação dos edifícios reabilitados de São Paulo ocorrem devido ao desenho inicial do programa de arrendamento, que não prevê um trabalho contínuo de administração e acompanhamento da população moradora e dos prédios após a entrega das unidades. Ações que priorizem os aspectos sócio-econômicos e de inserção para a população, em conjunto com ações que priorizem os aspectos de conservação e manutenção dos edifícios, devem ser planejados e viabilizados. Cabe ao órgão promotor redesenhar o programa, inserindo o planejamento de uma política de gerenciamento que englobe tanto os aspectos sociais, quanto físicos, financeiros, jurídicos e administrativos, a fim de garantir a sustentabilidade do programa. 


\section{Considerações finais}

O principal objetivo do trabalho foi identificar os fatores e as razões que induzem o surgimento de problemas na gestão pós-ocupação dos edifícios reabilitados voltados para Habitação de Interesse Social (HIS) no centro de São Paulo. As questões que se levantaram ao longo do processo dissertativo foram: o que acontece nos edifícios reabilitados que prejudica sua gestão após a entrada dos moradores? Como esta gestão poderia ser melhorada, garantindo a sustentabilidade do programa?

A gestão pós-ocupação em edifícios verticalizados voltados para HIS é um tema de recente abordagem no Brasil. Por este motivo, o trabalho procurou sistematizar os principais conceitos a ele relacionados, como administração, gestão condominial, assim como os principais aspectos que envolvem a habitação de interesse social e a população beneficiária. Ao mesmo tempo, o tema da reabilitação de edifícios também foi discutido durante o trabalho, uma vez que o objeto de estudo escolhido foi a gestão pós-ocupação de cinco edifícios reabilitados em São Paulo.

Foram levantados na pesquisa os aspectos relacionados à demanda, como características sócio-econômicas, e os aspectos relacionados ao edifício dentro do processo de reabilitação.

A população alvo do programa, famílias com renda mensal de três a seis salários mínimos, possui características específicas, por ser uma população heterogênea, composta por grupos sociais com diferentes vulnerabilidades, experiências de vida, inserções ocupacionais e de moradia (IEE, 2006). A mudança dessas famílias para um edifício verticalizado, composto por unidades habitacionais privativas e áreas comuns coletivas, transforma as relações sociais e econômicas existentes até então. A inserção em novo local, com novas regras e situações, precisa ser estruturada e acompanhada para que atenda ao objetivo completo da provisão habitacional.

De acordo com os levantamentos realizados, foram apontados pelos moradores diversos problemas ocorridos no período da pós-ocupação, tais como furtos e vandalismo nas áreas comuns, inadimplência das taxas condominiais, problemas técnicos no edifício (principalmente nos elevadores) e problemas administrativos. 
Algumas possíveis razões para estes problemas puderam ser apontadas. Entre os motivos que desencadearam os problemas sociais, destacaram-se três: a falta de um trabalho social contínuo com as famílias para garantir sua permanência; a falta de controle do órgão promotor sobre os edifícios e moradores durante a pósocupação; e a falta da sensação de pertencimento dos moradores por não serem os proprietários do imóvel.

Já as razões relacionadas aos problemas financeiros de moradores, que refletem diretamente na inadimplência das taxas, são: a inconstância da renda mensal das famílias devido ao desemprego; o acréscimo de valor nas taxas condominiais devido aos rateios dos custos de manutenção das áreas comuns; e a falta de pagamento por opção e por sensação de injustiça.

Os problemas construtivos podem ser justificados pelos equipamentos reformados e materiais empregados na obra de reabilitação; impossibilidade de realização de manutenção preventiva e corretiva devido aos custos gerados pelo serviço, não previstos no programa; e a falta de fornecimento de projetos e manuais de uso necessários aos usuários.

Com relação aos problemas administrativos, é possível identificar despreparo e falta de planejamento para o período da gestão pós-ocupação por parte da CEF, além da dificuldade e morosidade no processo de resolução de problemas existentes no edifício.

Ao longo do estudo foi possível perceber que o Programa de Arrendamento Residencial (PAR) gerido pela Caixa Econômica Federal (CEF) não prevê um trabalho específico para a fase da pós-ocupação. O programa é desenhado de maneira que a participação efetiva da CEF ocorra até o momento da entrega das chaves para os arrendatários. Após este período, o trabalho de acompanhamento realizado se resume a dois canais: uma administradora de condomínio, terceirizada e escolhida pela CEF, que realiza a gestão burocrática dos prédios e é a representante do edifício, e uma empresa executora do Trabalho Técnico Social (TTS), que realiza o acompanhamento durante seis meses, mas que não é estruturado o suficiente para manter as famílias no local, devido à pequena duração.

Dos cinco edifícios estudados, somente dois tiveram o TTS obrigatório realizado no período da mudança dos moradores, sendo que somente em um deles o trabalho obteve os resultados esperados. No outro, devido a grande rotatividade 
de moradores, o trabalho não foi aplicado às novas famílias, que acabaram mudando-se para o prédio sem nenhum tipo de instrução e acompanhamento. Nos outros edifícios em que não houve o TTS, o único contato que os arrendatários possuem com a CEF é realizado pela administradora do condomínio.

Fica claro, portanto, que a gestão pós-ocupação destes edifícios deveria ser planejada pelo órgão promotor, responsável pela sustentabilidade do programa.

Como alternativa para minimização destes problemas, é sugerido o redesenho do programa de arrendamento com o objetivo de planejar mais uma etapa do programa no período pós-ocupação, visando garantir a permanência dos moradores e a manutenção dos edifícios.

Esta etapa deve consistir em um trabalho social contínuo com os moradores, por meio de equipe multidisciplinar capaz de diagnosticar e resolver os problemas existentes nos prédios, sejam sociais, econômicos, psicológicos ou técnicos. Este trabalho de acompanhamento deve monitorar a população moradora dos edifícios, priorizando além das relações de vizinhança no condomínio, aspectos como emprego, saúde e educação.

Com relação aos aspectos físicos do edifício, é importante que se faça antes da mudança dos arrendatários, um trabalho de instrução com a população que diga respeito à utilização e manutenção dos sistemas do edifício. Além disso, é necessário que o programa tenha dentro de seu planejamento financeiro um fundo de reforma para os prédios, garantindo que algumas intervenções necessárias ao longo do tempo nas edificações, tais como pintura da fachada e manutenção dos elevadores, sejam realizadas e não tenham os custos repassados aos moradores.

No programa de arrendamento, o gerenciamento da fase da pós-ocupação dos prédios não poderia ser feito internamente pela CEF, pois por ser um programa de arrendamento, após 15 anos os moradores podem optar por quitar as unidades, tornando-se os proprietários do imóvel. A tendência é que no futuro estes edifícios não sejam mais propriedade da CEF e sim dos moradores, o que inviabilizaria qualquer ligação entre eles.

Para os edifícios reabilitados do PAR, entende-se que a operacionalização do período da pós-ocupação pode ser feita pela administradora de condomínio, desde que esta tenha seu escopo reformulado e apresente uma proposta de gestão completa. Esta reestruturação deverá garantir que, além dos aspectos 
administrativos já realizados, a empresa faça a gestão dos aspectos sócioeconômicos dos moradores, assim como aspectos físicos do edifício, tornando-se uma administradora específica para condomínios sociais.

Enfim, este trabalho completo de gestão pós-ocupação deverá ser aprofundado e estruturado de acordo com cada prédio e programa habitacional, garantindo que haja uma preparação para a entrada dos moradores, além de um controle e fiscalização durante o período de uso do edifício, necessários para que a proposta inicial de provisão habitacional do programa seja atendida.

A temática abordada na dissertação ainda é muito recente e merece ser aprofundada. Diversos aspectos que aqui foram rapidamente mencionados devido aos objetivos específicos deste trabalho poderão ser futuramente analisados e estudados a fim de construir mais um capítulo do estudo da gestão pós-ocupação para HIS.

Para posterior trabalho complementar ao tema, sugere-se um estudo específico sobre a composição das taxas de condomínio nestes prédios, elencando os pontos de maior valor e as medidas preventivas que poderiam ser tomadas para que estas taxas sejam reduzidas.

A partir destas considerações, pode-se afirmar que o objetivo proposto para o presente trabalho foi atingido, uma vez que foi possível analisar a gestão pósocupação em cinco edifícios reabilitados para habitação de interesse social em São Paulo. A partir dessa pesquisa, foram identificados os principais problemas existentes na gestão destes prédios, apontando as possíveis razões para estes conflitos. Além disso, a análise feita ao longo do quinto capítulo do trabalho pôde contribuir com algumas alternativas teóricas para a minimização dos problemas existentes na gestão pós-ocupação. 


\section{Referências bibliográficas}

AABIC. ASSOCIAÇÃO DAS ADMINISTRADORAS DE BENS IMÓVEIS E CONDOMÍNIOS DE SÃO PAULO. Apresenta as competências e atividades desenvolvidas. Disponível em: <http:// www.aabic.com.br>. Acesso em 17 de maio de 2008.

ACSERALD, H. Discursos da sustentabilidade urbana. Revista Brasileira de Estudos Urbanos e Regionais, Campinas, nº. 1, maio. 1999.

AGUIAR, J; CABRITA, A. M. R; APPLETON. J. Guião de apoio à reabilitação de edifícios habitacionais. 6 ed. Lisboa: Laboratório Nacional de Engenharia Civil, 2002. 2.v.

AMARAL, A. L. Pertencimento. Brasília: Ministério Público, 2006. Disponível em: $<$ http://www.esmpu.gov.br/dicionario/tiki-index.php?page=Pertencimento $>$ Acesso em 14/12/2008.

ANDERSON, N. Sociologia de la comunidad urbana. F.C. Economia. México, 1968.

ANJOS, A. L. 0 acesso ao solo e a habitação social em cidades grandes de regiões metropolitanas da América latina e Europa. São Paulo: Programa URBAL - Pré-diagnóstico do município de São Paulo, 2004.

ARAÚJO, L. C. G. Teoria Geral da Administração: aplicação e resultados nas empresas brasileiras. São Paulo: Editora Atlas, 2004.

ABNT. ASSOCIAÇÃO BRASILEIRA DE NORMAS TÉCNICAS. NBR14037: manual de operação, uso e manutenção das edificações: conteúdo e recomendações para a elaboração e apresentação. Rio de Janeiro, 1998.

NBR5674: manutenção de edificações: procedimento. Rio de Janeiro, 1999.

BARBOSA, E. Evolução do uso residencial na área central do Município de São Paulo. 2001. Dissertação (mestrado) - Escola Politécnica, Universidade de São Paulo, São Paulo, 2001. 
BARRETO SILVA, H. M. M. Terra e moradia: que papel para o município? 1997. Tese (doutorado) - Faculdade de Arquitetura e Urbanismo, Universidade de São Paulo, São Paulo, 1997.

. Documento preparatório. Encontro: Habitação no centro de São Paulo: Como viabilizar essa idéia. São Paulo: Laboratório de Habitação, Faculdade de Arquitetura e Urbanismo, Universidade de São Paulo/ Caixa Econômica Federal, 2000.

Observatório do uso do solo e da gestão fundiária do centro de São Paulo: Análise dos instrumentos urbanísticos e tributários. Laboratório de Habitação, Faculdade de Arquitetura e Urbanismo, Universidade de São Paulo/ Lincoln Institute. São Paulo, 2006.

BARROS, L. A. F. Adequação de uso de espaço habitacional produzido pelo estado. In: Encontro Nacional de Tecnologia do Ambiente Construído, 10., 2004, São Paulo. Anais... São Paulo, 2004.

BEZERRA, J. E. A. Um estudo da manutenção predial na gestão terceirizada dos condomínios com base na Manutenção Produtiva Total. 2000. Dissertação (mestrado) - Universidade Federal de Santa Catarina, Florianópolis, 2000.

BLANCO, M. Performance Verde. Revista Construção Mercado, São Paulo, $n^{\circ} 87$, p. 32-39, outubro 2008.

BOMFIM, V. C. Os espaços vazios na área central da cidade de São Paulo e a dinâmica urbana. 2004. Dissertação (mestrado) - Escola Politécnica, Universidade de São Paulo, São Paulo 2004.

BONDUKI, N. G. Origens da habitação social no Brasil. Arquitetura moderna, Lei do inquilinato e difusão da casa própria. São Paulo: Estação Liberdade FAPESP, 1998.

BOS, W.J. Inspection and planning manual: minimum quality standards and reference degradation pattern of building materials enquiring maintenance. In: CIB TRIENAL CONGRESS, 1989, Paris. Anais... Paris, 1989.

BRASIL. Ministério das Cidades. Secretaria Nacional de Habitação. Política Nacional de habitação. Brasília: Ministério das Cidades, 2004. 
BRASIL. Ministério das Cidades. Secretaria Nacional de Programas Urbanos. Programa de Reabilitação de áreas centrais. Manual para apresentação de propostas. Brasília: Ministério das Cidades, 2005.

BRASIL. Decreto Federal No 5.481/ 1928 - Condomínios.

. Lei Federal n² 4.591/ 1964 -Lei de condomínio.

Lei Federal n 10.406/ 2002 - Novo código civil.

. Lei Federal n 10.257/ 2001 - Estatuto da Cidade.

CEF. CAIXA ECONÔMICA FEDERAL. Apresenta os programas e atividades desenvolvidas. Disponível em: <http:// www.caixa.com.br>. Acesso em 07 de dezembro de 2008.

CARNEIRO, J. C. D. Padronização e melhoramento de processos em pequenas empresas administradoras de condomínios: um estudo de caso. 2002. Dissertação (mestrado) - Universidade Federal de Santa Catarina, Florianópolis, 2002.

CASFIG. COORDENAÇÃO DE ÂMBITO SOCIAL E FINANCEIRO DAS HABITAÇÕES SOCIAIS DE GUIMARÃES. Apresenta as competências e atividades desenvolvidas. Disponível em: <http://www.casfig.pt>. Acesso em 06 de dezembro de 2008.

CDHU. COMPANHIA DE DESENVOLVIMENTO HABITACIONAL E URBANO. Apresenta os programas e atividades desenvolvidos. Disponível em: $<$ http://www.cdhu.sp.gov.br>. Acesso em 26 de maio de 2007.

CEOTTO, L. H. Sustentabilidade em empreendimentos e empresas da construção. In: ENCONTRO SOBRE SUSTENTABILIDADE EM EMPREENDIMENTOS E EMPRESAS DA CONSTRUÇÃO. 2007, São Paulo. Disponível em: <http://www.cte.com.br/ eventos/essc/palestras.asp>. Acesso em 15 de julho de 2008.

CHIAVENATO, I. Introdução à teoria geral da administração. Rio de Janeiro: Ed. Campus, 1999. 
COELHO, A. B. Gestão integrada de parques habitacionais de arrendamento público. Lisboa: Departamento de Edifícios do Laboratório Nacional de Engenharia Civil, 1999.

COMISSÃO MUNDIAL SOBRE MEIO AMBIENTE E DESENVOLVIMENTO. Nosso futuro comum. Rio de Janeiro: Fundação Getulio Vargas, 1991.

CONTRERAS, L. C. Guia do Condomínio. São Paulo: Globo IDEC, 2001.

COSTA, L. Relatório do Plano-piloto de Brasília. (mimeo), 1957. Disponível em: <http://www.unb.br/fau/planodecurso/graduacao/12008/relatorio.pdf > . Acesso em 12 de novembro de 2008.

COUTO, A. P. Condomínio atrasado: Inadimplência não se deve a redução de multa. Revista Consultor Jurídico, setembro de 2005. Disponível em: $<$ http://www.conjur.com.br/2005set15/inadimplencia nao reducao multa $>$ Acesso em 28 de janeiro de 2008.

CURY. Apresenta as referências dos projetos realizados. Disponível em: <http://www.cury.net/site/pre master.asp $>$. Acesso em 10 de julho de 2007.

CYMBALISTA, R. et al. Habitação: controle social e política pública. São Paulo: Instituto Pólis, 2007. Série Observatório dos direitos do cidadão. Acompanhamento e análise das políticas públicas da cidade de São Paulo; № 31.

DAMATTA, R. A casa \& a Rua. Espaço, cidadania, mulher e morte no Brasil. $5^{\mathrm{a}} \mathrm{ed}$. Rio de Janeiro: Rocco, 1997.

DELERA, Anna. Edilizia pubblica: riqualificazione e progettazione partecipata. In: SEMINÁRIO INTERNACIONAL DE REABILITAÇÃO EM ÁREAS CENTRAIS. 2006, São Paulo. Palestras: São Paulo, REABILITA, 2006. Disponível em: $<$ http://reabilita.pcc.usp.br/palestras.htm>. Acesso em 08 de julho de 2008.

DRUCKER, Peter F. The practice of management. USA: Harper \& Row, 1965.

EASTAWAY, M. P. What do we understand by a sustainable urban regeneration process? Visions about the future of restructured housing estates in Spain. In: RESTATE PROJECT. 2007, Espanha. Disponível em: $<$ http://www.restate.geog.uu.nl/>. Acesso em 27 de maio de 2008. 
FIPE - Fundação Instituto de Pesquisas Econômicas. Estudo de favelas e cortiços da cidade de São Paulo, relatório final. São Paulo: FIPE, 1994.

FLOSI, Carina. Imóveis à venda no Cingapura e Gato. O Estado de S. Paulo. São Paulo, 09 de maio de 2006. Metrópole, p.C4.

FREYRE, G. Oh de casa! Recife: IPNPS, 1979.

FJP. FUNDAÇÃO JOÃO PINHEIRO. Déficit Habitacional no Brasil. $2^{a}$ ed. Centro de Estatística e Informações, Brasília, 2006.

FORUM CENTRO VIVO. Dossiê Fórum Centro Vivo - Violações dos direitos humanos no centro de São Paulo: propostas e reivindicações para políticas públicas. Disponível em: <http://www.centrovivo.org>. Acesso em 18 de agosto de 2008.

HOEK-SMIT, M.; DIAMOND, D. B. Subsidies for housing finance. Housing Finance International, v. 17, n. 3. Março, 2003.

IBGE Instituto Brasileiro de Geografia e Estatística. Anuário estatístico do Brasil. v. 63, Rio de Janeiro, IBGE, 2003.

. Malha Censitária do Censo Demográfico de 2000. Brasília, IBGE, 2000.

IEE. INSTITUTO DE ESTUDOS ESPECIAIS. Metodologia/ Plano de trabalho social programa de locação social. Pontifícia Universidade Católica: São Paulo, 2006.

LEME, M. A. A. S. Administração de condomínios residenciais verticais. A reimaginação do cotidiano. 1995. Dissertação (mestrado) - Pontifícia Universidade Católica, São Paulo, 1995.

LICHTENSTEIN, N. B. Patologia das construções: procedimento para formulação do diagnóstico de falhas e definição de conduta à recuperação de edificações. 1985. Dissertação (mestrado) - Escola Politécnica, Universidade de São Paulo, São Paulo, 1985.

LOPES, J. B. Condomínio. 9a ed. São Paulo: Editora Revista dos Tribunais, 2006. 
LOPES, M. F. A reabilitação urbana em Lisboa. In: SEMINÁRIO INTERNACIONAL DE REABILITAÇÃO EM ÁREAS CENTRAIS. 2006, São Paulo. Palestras: São Paulo, REABILITA, 2006. Disponível em: < http://reabilita.pcc.usp.br/palestras.htm>. Acesso em 08 de julho de 2008.

MALERONKA, C. PAR-REFORMA: Quem se habilita? A Viabilização de empreendimentos habitacionais em São Paulo através do Programa de Arrendamento Residencial - Modalidade Reforma: 1999-2003. 2005. Dissertação (mestrado) - Instituto de Pesquisas Tecnológicas do Estado de São Paulo, São Paulo, 2005.

MARQUES DE JESUS, C. R. Análise de custos para reabilitação de edifícios para habitação. 2008. Dissertação (mestrado) - Escola Politécnica, Universidade de São Paulo, São Paulo, 2008.

MARICATO, E. A produção capitalista da casa (e da cidade) no Brasil industrial. São Paulo: Alfa-Ômega, 1979.

2001.

. Brasil, cidades: alternativas para a crise urbana. Rio de Janeiro: Vozes,

. Construindo a Política Urbana: participação democrática e o direito à cidade. In: RIBEIRO, L.C.Q. e JUNIOR, O.A.S. As metrópoles e a questão social brasileira. Rio de Janeiro: Revan, Fase, 2007.

MEDEIROS, F. B. Análise da adequação dos programas de financiamento habitacional para atender às necessidades de aquisição de moradias adequadas da população de baixa renda no Brasil. 2007. Dissertação (mestrado) - Escola Politécnica, Universidade de São Paulo, São Paulo, 2007.

MEGGINSON, L. C; MOSLEY, D. C; PIETRI JR; PAUL H. Administração: Conceitos e Aplicações. 4. ed. São Paulo: Harbra, 1998.

MENEZES, F. C. O Programa de Arrendamento Residencial e a Aplicação do Código de Defesa do Consumidor. Disponível em: <http://www.dpu.gov.br/pdf/ artigos/Artigo\%20Dr\%5B1\%5D.\%20Felipe\%2018022008.pdf>. Acesso em 15 de dezembro de 2008. Brasília, 2008.

MESQUITA, M. J. M. Subsídios para o planejamento da qualidade em edifícios do segmento hoteleiro. 2006. Dissertação (mestrado) Escola Politécnica, Universidade de São Paulo, São Paulo, 2006. 
MICHAELIS: Moderno dicionário da língua portuguesa. São Paulo: Companhia Melhoramentos, 1998.

MONICE, S. Reforma de Edifícios para HIS na região central de São Paulo, através do Programa de Arrendamento Residencial. Trabalho apresentado no Encontro Técnico - Projeto Reabilita, 2006, Salvador. Não publicado.

MOTTA, C.F.A. Nível de satisfação em conjuntos habitacionais da Grande São Paulo. $1^{\circ}$ v. São Paulo: IPT/ FAPESP, 1975.

MOTTA, P. R. Gestão Contemporânea: a ciência e a arte de ser dirigente. $5^{a}$ ed. Rio de Janeiro: Editora Record, 1995.

NAVAZINAS, V. Arquitetura possível: os espaços comuns na habitação de interesse social em São Paulo. 2007. Dissertação (mestrado) - Faculdade de Arquitetura e Urbanismo, Universidade de São Paulo, São Paulo, 2007.

PADOVANI, P. W. A gestão local na reabilitação urbana de áreas centrais: os casos de Lisboa e São Paulo. 2005. Dissertação (mestrado) - Faculdade de Arquitetura e Urbanismo, Universidade de São Paulo, São Paulo, 2005.

PEREZ, A. R. Manutenção de Edifícios. Tecnologia de Edificações, $n$ ․ 2. São Paulo: Pini, 1985.

PLANO Diretor Participativo. Guia para a elaboração pelos municípios e cidadãos. Brasília, 2004.

PMSP. PREFEITURA MUNICIPAL DE SÃO PAULO. Plano municipal de habitação. São Paulo, 2002.

. Programa Morar no centro. São Paulo, 2004.

. Relatório Executivo: Residencial Parque do Gato e Residencial Olarias. São Paulo, outubro de 2005. Não publicado.

. Apresenta os programas e atividades desenvolvidos. Disponível em:

<http:// www.prefeitura.sp.gov.br>. Acesso em 02 de novembro de 2007. 
PRISMA. O pulo do gato. ed.13. Disponível em:

<http://www.revistaprisma.com.br/habitacao/habitacao 13.html>

Acesso em 28 de julho de 2008.

REABILITA. Diretrizes para reabilitação de edifícios para HIS: as experiências em São Paulo, Salvador e Rio de Janeiro - Projeto Reabilita. São Paulo: Departamento de Engenharia de Construção Civil, Escola Politécnica, Universidade de São Paulo/ Universidade Católica de Salvador/ Universidade Federal do Rio de Janeiro. São Paulo, 2007.

RIGATTI, D. Do espaço projetado ao espaço vivido: modelos de morfologia urbana no conjunto Rubem Berta. 1997. Tese (doutorado) - Faculdade de Arquitetura e Urbanismo, Universidade de São Paulo, São Paulo, 1997.

RIZZO, B. Manutenção predial. Rio de Janeiro, 2004. Disponível em: <http://www.secovi-rj.com.br> Acesso em 15 de abril de 2006.

SALCEDO, R. Programa de Arrendamento Residencial (PAR): Reabilitação do Edifício Residencial Maria Paula, Centro Histórico de São Paulo (Brasil). In: CONGRESSO INTERNACIONAL DE REHABILITACIÓN DEL PATRIMONIO ARQUITECTONICO Y EDIFICACION, 8., Buenos Aires, 2006. Disponível em: $<$ http://www.cicopar.com.ar/congreso/x-fernandez.htm>. Acesso em 18 de maio de 2008.

SAMPAIO, M. R. A. A Promoção Privada de Habitação Econômica e a Arquitetura Moderna. São Paulo: Rima, 2002.

SANCHES, D. Gestão condominial de habitação de interesse social: estudo da área central de São Paulo. 2008. Dissertação (mestrado) - Instituto de Pesquisas Tecnológicas, São Paulo, 2008.

SÃO PAULO (município). Lei N 13.430, de 13 de setembro de 2002. Plano Diretor da Cidade de São Paulo. São Paulo, 2002.

SCHWARTZ, R. B. O. Revolucionando o condomínio. 11ª ed. São Paulo: Editora Saraiva, 2007.

SEELEY, I.H. Building Maintenance. London: Macmillan, 1987.

SILVA, D. P. Vocabulário jurídico. 5 ed. Rio de Janeiro, Forense, 1978. 
SILVA, R. O. Teorias da administração. São Paulo: Pioneira Thomson Learning, 2004.

STECHHAHN, C. Projeto e apropriação do espaço arquitetônico de conjuntos habitacionais de baixa renda. 1990. Tese (doutorado) - Faculdade de Arquitetura e Urbanismo, Universidade de São Paulo, São Paulo,1990.

STREN, R; POLÉSE, M. The Social Sustainability of Cities: Diversity and the Management of Change. Toronto: University of Toronto Press, 2000.

VITALE, L. et al. Perímetro de Reabilitação Integrada do Habitat - PRIH. Uma experiência de intervenção nas áreas centrais. In: Encontro da Associação Nacional de Pós-graduação e Pesquisa em Planejamento urbano regional - ANPUR, 11., 2005. Salvador. Anais... Salvador, 2005.

YOLLE NETO, J. Diretrizes para o estudo de viabilidade da reabilitação de edifícios antigos na região central de São Paulo visando a produção de HIS: estudo de casos inseridos no Programa de Arrendamento Residencial (PARReforma) - Edifícios: Olga Benário, Labor e Joaquim Carlos. 2006. Dissertação (mestrado) - Escola Politécnica, Universidade de São Paulo, São Paulo, 2006.

ZANDONADE, P. Conjuntos habitacionais no tecido urbano da área metropolitana de São Paulo. O caso da região leste (1930/ 1986). 2005. Dissertação (mestrado) - Faculdade de Arquitetura e Urbanismo, Universidade de São Paulo, São Paulo, 2005. 